\title{
Estudios de
}

Deusto

Vol. 44/2 Julio-Diciembre 1996

\section{Sumario}

El Derecho de la persona en Europa hoy

R. de Angel Yágüez

La extraordinaria y urgente necesidad en el Real Decreto-ley 5/1996, de 7 de junio, de medidas liberalizadoras en materia de suelo y colegios profesionales J.L. Avila Orive
Análisis y seguimiento de drogodependientes de opiáceos

F. Calvo Gómez

Los principios generales del Derecho y la justicia J.M. Fernández Hierro

La fundación: somero análisis de la Ley 12/1994 del Parlamento Vasco J.M. Fernández Hierro
Unamuno y la revista francesa "Monde»

(1928-1934)

M.M. ${ }^{a}$ Urrutia

Daños punitivos en el proceso civil norteamericano G. Vadillo Robredo

Simposium sobre "Evangelium vitae y Derecho". Roma, 23-25 de mayo de 1995 P.M. ${ }^{\text {a Garín }}$

Urionabarrenechea

Universidad de Deusto 



\section{Estudios de Deusto}





\section{Estudios de Deusto}

Revista de la Universidad de Deusto

Segunda época. Vol. 44/2

Desde su fundación vol. 57

(Fasc. 97)

Julio-Diciembre 1996

Bilbao

Universidad de Deusto

1996 


\section{Director:}

Ignacio María Beobide

\section{Consejo Asesor:}

María Alvarez

Jorge Caramés

Francisco Garmendia

José María Lidón

José María Merino

Jaime Oráa

Demetrio Velasco

\section{Administración:}

Secretaría Técnica

Universidad de Deusto - Apartado 1 - E48080 Bilbao

Tfno.: (94) 4139000 Fax: (94) 4456817

\section{Distribución:}

Ediciones Mensajero

Sancho Azpeitia, 2 - E48014 Bilbao

Tfno.: (94) $4470358 \quad$ Fax: (94) 4472630

\section{Precios de Suscripción:}

España 4.000 ptas

Extranjero

$50 \$$

Número suelto

2.200 ptas

Ninguna parte de esta publicación, incluido el diseño de la cubierta, puede ser reproducida, almacenada o transmitida en manera alguna ni por ningún medio, ya sea eléctrico, químico, mecánico, óptico, de grabación, o de fotocopia, sin permiso previo del editor.

Publicación impresa en papel ecológico

(C) Universidad de Deusto Apartado 1 - 48080 Bilbao

I.S.S.N.: $0423-4847$

Depósito legal: BI - 2350-96

Impreso en España/Printed in Spain

Fotocomposición: IPAR, S.Coop. - Bilbao

Impresión: Artes Gráficas Rontegui, S.A.L. 


\section{Sumario}

\section{Estudios}

R. DE ANGel YÁgüEz, El Derecho de la persona en Europa hoy

J.L. AVILA ORIVE, La extraordinaria y urgente necesidad en el Decretoley 5/1996, de 7 de junio, de medidas liberalizadoras en materia de suelo y colegios profesionales

F. CALVo GómEZ, Análisis y seguimiento de drogodependientes de opiáceos

J.M. Fernández Hierro, Los principios generales de Derecho y la justicia

J.M. FeRnÁndez HieRRo, La fundación: somero análisis de la Ley 12/1994 del Parlamento Vasco

M.M. ${ }^{a}$ URRUTIA, Unamuno y la revista francesa «Monde» (1928-1934)

G. VADILLo Robredo, Daños punitivos en el proceso civil norteamericano

\section{Crónica}

P.M. ${ }^{a}$ Garín UrionabarReneCheA, Simposium sobre «Evangelium vitae y Derecho». Roma, 23-25 de mayo de 1995

Vol. 44/2 Julio-Diciembre 1996 



\section{ESTUDIOS}





\title{
EL DERECHO DE LA PERSONA EN EUROPA HOY ${ }^{1}$
}

\author{
Ricardo de Angel Yágüez \\ Catedrático de Derecho civil de la Universidad de Deusto
}

1. Se adjudica a mi ponencia el título de «El Derecho de la persona en Europa hoy». Mucho me gustaría que, más que tener un carácter descriptivo, mi intervención pudiera formular algún vaticinio sobre el papel que la persona va a desempeñar en el Derecho civil del futuro. Pero hacer previsiones en Derecho es siempre sumamente aventurado. Cuando todavía hace sólo unos veinte años afirmábamos que una de las características del Derecho civil de entonces era su llamada «administrativización» (esto es, la creciente presencia de reglas de Derecho público en las relaciones inter privatos), no podíamos imaginar que en este final de siglo iba a desencadenarse la febril tendencia de «desregulaciones» - fruto a su vez del neoliberalismo, de las privatizaciones y de otros fenómenos que del primero traen causa- que hoy es signo de amplios sectores de la actividad económica y de su expresión jurídica.

Por eso, creo que no es tanto cuestión de hacer especulaciones sobre el mañana, sino de intentar describir los rasgos que me parecen más significativos del Derecho de la persona en el momento presente.

Por otro lado, el título atribuido a mi ponencia es demasiado ambicioso (hasta el punto de superar mis posibilidades), si lo que con ese epígrafe se busca es una descripción cabal de lo que en la materia que nos ocupa se observa en los ordenamientos más significativos de nuestro viejo continente. Por eso, forzoso es advertir que mi exposición versará sobre los rasgos actuales del Derecho de la persona en el ordenamiento español, en tanto en cuanto - según mis conocimientos- coincide con lo que ocurre en otros países europeos.

1 Se reproduce el texto de la conferencia inaugural pronunciada por el autor en el Congreso Internacional La persona y el Derecho en el fin de siglo, celebrado en Santa Fe, Argentina, del 24 al 26 de octubre de 1996. 
He de señalar, además, que mi aportación no se va a limitar al ámbito de lo que habitualmente conocemos como la responsabilidad civil o Derecho de daños, sino que procurará tomar como punto de partida los caracteres más salientes, ahora, de esa parcela del Derecho civil que conocemos como «Derecho de la persona».

2. A mi juicio, una forma de resumir el estado actual del Derecho de la persona en Europa es la de decir que refleja contrastes. Del mismo modo que hoy hablamos retrospectivamente de épocas de apogeo y de crisis del contrato, aunque refiriéndonos a momentos históricos sucesivos, ahora podría utilizarse ese binomio diciendo que, en efecto, el Derecho de la persona atraviesa por un momento de exaltación y, de otra parte, por una fase de declive.

Voy a tratar de ilustrar esta impresión (no me atrevo a darle otro nombre más científico) con algunas observaciones.

3. En primer lugar, puede afirmarse que el Derecho de la persona está conociendo un llamativo desarrollo.

Me refiero por ahora a datos puramente cuantitativos, por así decirlo, como los siguientes:

La bibliografía europea sobre la persona y los llamados derechos de la personalidad es abundantísima en los últimos tiempos. Basta echar una ojeada a los catálogos editoriales para fundar esta aseveración. Es notable el crecimiento, en proporción con otras materias de Derecho civil, de la que ahora nos ocupa.

De otra parte, en los tratados y manuales de Derecho civil es ostensible el incremento del apartado correspondiente al Derecho de la persona (según es habitual, en la parte general de Derecho civil), quizá en detrimento de temas que hemos considerado siempre más «clásicos» o propios de dicha parte general, como por ejemplo el derecho subjetivo y el negocio jurídico.

Por último, desde el punto de vista del Derecho positivo, los ordenamientos civiles europeos han dado entrada, bien por vía de sus códigos civiles, bien a través de leyes especiales, a una mayor atención a la persona. Se ha superado con creces su histórica reducción al estado civil o poco más; sobre todo, como consecuencia de la reglamentación de los derechos de la personalidad.

4. Todo ello, desde luego, no es una casualidad, sino que responde a profundas razones de fondo.

Ese fondo es la emergencia de los valores de la persona (señaladamente a partir de la Segunda Guerra Mundial) y, sobre todo, la reivindicación de una tutela jurídica para esos valores; esto es, superada ya la idea de otro tiempo de que sus vulneraciones sólo podían ser objeto de reproche moral. 
Es interesante poner de manifiesto que la inicial posición contraria a la «juridificación» de los derechos de la personalidad procedió, paradójicamente, de sectores que, por ser muy respetuosos hacia los valores individuales, consideraron que es indigno equipararlos a los meros intereses patrimoniales. Fue una tendencia del mundo jurídico anglosajón, pionero, por otra parte, de las libertades cívicas. Resulta significativa, por citar un ejemplo, la fundamentación de un fallo de la jurisprudencia norteamericana. Se trata de una sentencia de 1902, en la que se ventilaba la reclamación entablada por una señorita que demandaba a un fabricante de harina porque en los envases de su producto reproducía la fotografía de aquélla, desde luego muy púdica. El Tribunal desestimó la demanda de la ofendida, en la que ésta solicitaba una indemnización. El razonamiento de la sentencia giró en torno al pensamiento siguiente: «Hay muchas obligaciones que son demasiado delicadas y sutiles para ser puestas en vigor mediante el rudo método de indemnizarlas en caso de violación. Acaso los sentimientos ofendidos encuentran la mejor protección posible en el derecho moral y en una opinión pública favorable». En la declaración del Tribunal late una resignada afirmación sobre la impotencia del Derecho para hacer frente a situaciones que, precisamente por la dignidad de los valores puestos en juego, han de dejarse a un cumplimiento espontáneo y a una satisfacción estrictamente moral.

Incluso en los últimos tiempos, la «legalización» de los derechos de la personalidad ha suscitado alguna duda y hasta abiertos reproches. Se afirma, por ejemplo, que el respeto a los derechos de la personalidad depende del clima social imperante en cada país y que, en consecuencia, lo que en unos puede ser una política legislativa necesaria, en otros puede resultar contraproducente, en el sentido de crear de manera artificial problemas sociales antes desconocidos. De campos ajenos al Derecho procede el argumento de que no es conveniente que las normas jurídicas se interfieran en esta cuestión, dificultando la solución espontánea de los conflictos; que, evidentemente, es lo que constituye el desideratum desde un punto de vista estrictamente social. Algún autor ha llegado a invocar la teoría de que toda elaboración legislativa al respecto crea un clima de tal apasionamiento que las ventajas se ven superadas por los inconvenientes.

5. Pero, al margen de estas aisladas reticencias, es innegable que los últimos cuarenta o cincuenta años han conocido una vigorosa tendencia hacia la recuperación del valor central de la persona en el Derecho civil.

Es menester recordar que, al comienzo de esa época, una de las notas del Derecho civil fue la de su llamada «patrimonialización». Este fenómeno, sobre el que tan brillantemente escribió DIEZ-PICAZO en 1959, 
tuvo su origen en la corriente filosófica del racionalismo jurídico. Cuando se pierde, con la Reforma protestante, el enlace íntimo del Derecho civil con la concepción católica de la vida, inconscientemente quizá el hombre quedó aislado de su conexión con la Divinidad y de su conexión con la comunidad. Se rompió así el hilo sutil que enmarcaba a la persona, en todas sus dimensiones, dentro de la vida social. Esta soledad del ser humano daría lugar al racionalismo filosófico — pues sólo la razón del hombre es fuente de conocimiento-y al individualismo jurídico. La exaltación de los fines puramente materiales de la existencia, antes sometidos a los de carácter sobrenatural, hará aparecer la figura del homo oeconomicus. Por ello, como señalaba DIEZ-PICAZO, «nada tiene de extraño que el Derecho civil apareciese como el Derecho defensor de este tipo de fines, como el Derecho establecido para la realización de los fines económicos del hombre». De ahí la preeminencia del Derecho patrimonial o Derecho de bienes, desdibujándose aquellas partes del Derecho civil que contemplan fines de naturaleza distinta.

Y el mismo autor hizo una excelente síntesis con las siguientes palabras: «Coincidiendo con ello, la persona, su estado y su esfera jurídica desaparecen del sistema. Deja de existir un Derecho de la persona, para quedar ésta convertida en un puro valor instrumental: el de sujeto de una relación jurídica, casi siempre de carácter patrimonial. El estado y condición de la persona son contemplados como simples requisitos subjetivos de la relación jurídica. El poder la persona sobre su propia esfera jurídica (nombre, honor, buena fama, vida, integridad, pensamiento, etc.) están ausentes del Derecho civil. Al Derecho civil se le ha privado así de lo más sustancial que tenía. Pues si su función y su finalidad no es otra que la defensa de la persona y de sus fines, ésta, como primera realidad jurídica, habría de ser el centro del sistema».

También en la doctrina española, DE CASTRO había hecho notar, ya en los años 40, que los autores antiguos de Derecho civil apenas aludían a los derechos de la personalidad, fenómeno que el maestro explicaba por la tendencia especializadora de la ciencia jurídica, que trasladó esta materia al campo de la Teología moral, primero, y más tarde al Derecho público. Esta circunstancia permite entender, entre otras cosas, el silencio casi absoluto que los códigos de la familia del francés mostraron en relación con estos derechos.

También pudo contribuir a ese fenómeno, a mi juicio, el hecho de que hasta el siglo XVIII la persona se hallase filosófica y socialmente diluida en un marco en el que toda reacción defensiva se proyectaba en contra de un poder político absoluto. A partir de la Ilustración, la preocupación se centró en la formulación y salvaguardia de los derechos de la 
persona frente a ese poder, su máximo enemigo; y todos los logros se orientaron en el terreno de las libertades políticas.

Sólo cuando la persona consiguió un minimum de seguridad frente al poder, fue cuando sus preocupaciones se desplazaron al terreno de las relaciones privadas, en las que pronto empezaron a verse amenazados los valores más íntimos del individuo, colocado en una civilización que cada día - como dijo SAVATIER - se hacía más hostil para él.

Nació así un reacción defensiva, manifestada en una conciencia social sensible a los atentados contra la persona y sus cualidades. Y surgió, paralelamente, una mayor preocupación por los «derechos de la personalidad» en sentido estricto, materializada en un notable crecimiento de la bibliografía dedicada al tema y en la atención que le dedicaron códigos civiles como el italiano de 1942 o el portugués de 1967. En los trabajos preparatorios de la reforma del Código civil francés, tan abandonados que hoy son casi una cita histórica, la materia de los derechos de la personalidad era objeto de muy particular atención.

6. Ahora, como decíamos, el panorama es distinto. Se reclama para el Derecho civil la recuperación de su sentido histórico de Derecho dictado para la defensa y protección de la persona y para la realización de sus fines. El Derecho civil — se dice- puede ser un instrumento muy adecuado para poner coto a la excesiva injerencia estatal en la órbita de actuación de la persona y, contra el excesivo auge de los valores económicos, para recoger la totalidad de los fines de la persona y agrupar debidamente jerarquizadas las instituciones que los realicen.

Dicho de otro modo, la recuperación por el Derecho civil de los derechos de la persona se ha defendido con el siguiente razonamiento: si la regulación de todo lo referente a la persona y a los derechos personales se abandona a la competencia del Derecho público, estaremos minando nada más y nada menos que una de las materias más sagradas y tradicionales dentro del Derecho privado; se llegaría a poner en tela de juicio la razón de ser y la existencia misma del Derecho civil.

7. Particular relieve en este proceso ha tenido la doctrina de los llamados «derechos de la personalidad». Con este nombre se viene designando a una amplia y heterogénea serie de prerrogativas y poderes que garantizan a la persona el goce de las facultades del cuerpo y del espíritu o, dicho de otro modo, que aseguran al individuo el respeto a su personalidad física y moral.

La inquietud del Derecho civil por los derechos de la personalidad tiene su origen en el Derecho público, en concreto en la doctrina de los «derechos humanos». Estos, según la terminología comúnmente admitida, se desenvuelven en el plano de las relaciones individuo-Estado y ex- 
presan las libertades individuales que los poderes públicos no pueden menoscabar (o no pueden hacerlo sino de forma tasada, limitada y transitoria).

La transposición de los derechos humanos al campo del Derecho civil tiene su asiento en la observación de que también en el ámbito de las relaciones privadas los derechos de la persona exigen una tutela jurídica adecuada. En ese plano es donde hablamos de los «derechos de la personalidad», presentes en la doctrina del Derecho de la persona, en la del derecho subjetivo, en la de la autonomía privada $\mathrm{y}$, sobre todo, en sede de responsabilidad civil o Derecho de daños.

Antes de que por vía legal o jurisprudencial adquiriesen los derechos de la personalidad carta de naturaleza en el Derecho civil, la doctrina de los derechos humanos inspiró muchas de las propuestas formuladas para dar respuesta a conflictos entre particulares. Recuérdense las discusiones sobre si el Convenio europeo de salvaguarda de los derechos del hombre y de las libertades fundamentales (de Roma, 1950) vinculaba sólo a los Estatos contratantes o si alcanzaba también a los individuos situados bajo su jurisdicción. Esta segunda interpretación, la que otorga a los preceptos del Convenio una «eficacia absoluta», en el sentido de afectar a terceros (Drittwirkung), corresponde — según sostenían sus defensoresa las necesidades de nuestra época, protegiendo a los particulares contra sus semejantes y no sólo contra el poder público.

Esta fue, salvadas pequeñas distancias, la misma pregunta que se planteó a la luz de ciertos textos constitucionales que garantizan el ejercicio de las libertades individuales: han suscitado el problema de si son directamente aplicables a casos de vulneración por parte de las personas privadas o si, por el contrario, alcanzan tan sólo a las violaciones por parte del Estado o sus órganos. Es la cuestión acerca de lo que la doctrina alemana llamó Drittwirkung der Grundrechte (oponibilidad de los derechos fundamentales frente a las personas privadas), pregunta que en definitiva se inclinó en Alemania por la tesis afirmativa y que fue seguida también por la jurisprudencia de otros países.

El carácter ambivalente de los derechos humanos, en el sentido más amplio de la expresión (esto es, su manifestación en las relaciones individuo-Estado y su expresión en las relaciones individuo-individuo, esto último ya como «derechos de la personalidad»), se muestra de forma visible en muchas hipótesis. Esa doble faceta puede hacer que una misma «libertad» opere bajo el dominio del Derecho público o del privado, según los casos.

Es muy claro, por ejemplo, el de la libertad religiosa. En su aspecto de Derecho público se concreta en la libertad de cultos (libertad de opción religiosa) y en la supresión de toda discriminación entre los ciu- 
dadanos por razón de la religión que profesen. Como derecho de la personalidad - en el terreno del Derecho privado - se proyecta en todo tipo de situaciones jurídicas que puedan suponer lesión a los sentimientos religiosos o a cualquiera de las formas concretas de actuación derivadas de la convicción o el credo religiosos. Alcanzaría, por ejemplo, a hipótesis tan diversas como las que siguen: anulación de un matrimonio por haber ocultado un consorte su profesión de una determinada religión; anulación del contraído ignorando uno de los cónyuges que el otro estaba ya casado de acuerdo con las prescripciones de otra religión; imposición de responsabilidad al cónyuge que obliga al otro a sufrir las consecuencias del divorcio cuando esta institución ofendiese los sentimientos del consorte inocente; responsabilidad civil del profesor que ofende gravemente los sentimientos religiosos de sus alumnos; declaración del carácter abusivo de la negativa del padre, hecha bruscamente en el momento del nacimiento, de bautizar a un hijo, con ofensa a la «conciencia de una mujer cristiana en sus sentimientos más íntimos y respetables»; responsabilidad civil de quien ofende los sentimientos religiosos de un ministro de determinada religión o de un miembro de una orden religiosa; o del periódico que publica la lista de los participantes en una peregrinación; separación matrimonial basada en el hecho de haber ejercido un cónyuge violencia sobre el otro para obligarle a cambiar la religión; etc.

El profesor Jean RIVERO puso de relieve, hace 25 años, el error que se venía sufriendo cuando se pensaba que los derechos humanos sólo se proyectaban en el terreno político. Lo hizo, precisamente, al justificar el título del volumen tercero de los estudios dedicados a René CASSIN ( $L a$ protection des droits l'homme dans les rapports entre personnes privées).

Decía RIVERO: «El tema escogido para esta obra parece haber causado alguna sorpresa. Los que se preocupan de la protección de los derechos del hombre piensan sobre todo en la amenaza que sobre ellos hace pesar el poder del Estado».

Sin embargo - añadía el autor- no es éste el único riesgo que recae sobre la persona. Si el Estado puede oprimir, en efecto, es porque se halla, en relación con los que viven bajo su esfera, en posición de superioridad. A partir de esta evidencia, se impone una generalización: toda relación no igualitaria en la sociedad permite a quien domina incidir sobre los comportamientos de quien es dominado; atentar, por tanto, contra la libertad del débil. El individualismo idealista surgido de la tradición de 1789 ha creído poder eludir esta realidad, afirmando la igualdad de todos los hombres. Esto venía a constituir, desde luego, la supresión de una de las fuentes de desigualdad, la que la misma ley consagraba. Pero las que resultan de la naturaleza del hombre permanecen todavía. De la brutalidad de la supremacía física a la acción más sutil de la dominación inte- 
lectual o moral, pasando por el campo inmenso de las superioridades económicas, la lista es larga, sólo en lo que se refiere a los individuos. Si se incluyen, además, las personas jurídicas de Derecho privado, los desequilibrios se multiplican y agravan. En definitiva, pocos son quienes, en una sociedad, no dependen de otro en buena parte de su existencia.

Y más adelante, con la misma lucidez, RIVERO escribía: «La amenaza que el Estado hace pesar sobre el ejercicio de los derechos del hombre no es más que un aspecto particular de un fenómeno mucho más general: la amenaza que el fuerte despliega sobre la libertad del débil. Cierto es que la amenaza estatal es más visible y más temible, en proporción al grado de poder de coacción de que dispone el Estado; se explica que haya sido la primera en atraer la atención de los defensores de la libertad. Pero para que los derechos del hombre se vivan de verdad es necesario empeñarse en hacerlos respetar en las relaciones entre las personas privadas».

8. Otra manifestación del relieve que a la persona se le reconoce en los últimos tiempos es lo que podríamos denominar genéricamente como proceso de eliminación de discriminaciones.

Piénsese, por ejemplo, en la ya consumada desaparición de la filiación ilegítima en nuestros textos legales y, por tanto, en la desaparición de toda diversidad de trato de la persona por razón de su filiación. En España, este proceso culminó con las radicales reformas que el Código civil experimentó en 1981 para acompasar su regulación a los imperativos de la Constitución de 1978.

Dentro de este mismo capítulo tiene cabida la culminación de la equiparación jurídica de los sexos y la desaparición de toda clase de discriminaciones por su causa. Por lo que se refiere al ordenamiento español, también en 1981 se materializó este objetivo, consagrando entre otras cosas la igualdad jurídica entre marido y mujer en el régimen personal y económico del matrimonio y en la patria potestad.

9. Los niños (y en general los menores) vienen siendo destinatarios de normas tuitivas particularmente dirigidas a ellos. Al hilo de la Convención de derechos del niño, de Naciones Unidas (de 20 de noviembre de 1989), y de la Carta Europea de los derechos del niño (de 1992), casi todos los países europeos han ido dictando leyes orientadas a dotar de un nuevo régimen a instituciones clásicas, pero ahora tomando al menor como eje o centro de las mismas.

Es significativo, en España, el caso de las más recientes modificaciones del Código civil en materia de tutela (24 de octubre de 1983) y de adopción (11 de noviembre de 1987). En ellas se observa ese cambio de signo que antes he apuntado, que va mucho más allá de lo formal. El me- 
nor no es ya el objeto de las normas respectivas, sino un genuino protagonista de las instituciones reguladas.

Como última novedad tiene que ser citada la Ley orgánica de 15 de enero de 1996, de protección jurídica del menor. Su preámbulo insiste en la condición de sujeto de derechos de la persona menor de edad. Así, el concepto «ser escuchado si tuviere suficiente juicio» se ha ido trasladando a todo el ordenamiento jurídico y en todas aquellas cuestiones que le afectan. Esta concreta Ley, en particular, refleja una concepción de los menores de edad como sujetos activos, participativos y creativos, con capacidad de modificar su propio medio personal y social; de participar en la búsqueda y satisfacción de sus necesidades y en la satisfacción de las necesidades de los demás.

La misma exposición de motivos de la Ley dice: «El conocimiento científico actual nos permite concluir que no existe una diferencia tajante entre las necesidades de protección y las necesidades relacionadas con la autonomía del sujeto, sino que la mejor forma de garantizar social y jurídicamente la protección a la infancia es promover su autonomía como sujetos. De esta manera podrán ir construyendo progresivamente una percepción de control acerca de su situación personal y de su proyección de futuro. Este es el punto crítico de todos los sistemas de protección a la infancia en la actualidad. Y, por lo tanto, es el reto para todos los ordenamientos jurídicos y los dispositivos de promoción y protección de las personas menores de edad. Esta es la concepción del sujeto sobre la que descansa la presente Ley: las necesidades de los menores como eje de sus derechos y de su protección».

Ahora bien, no engañaríamos si se silenciasen las sombras que oscurecen la condición jurídica del niño.

Cuando se leen sonoras declaraciones como las que la citada Ley española proclama (por ejemplo, el derecho del menor a la libertad de ideología, conciencia y religión, o su derecho a la libertad de expresión), se tiene la sensación de que ciertas normas jurídicas son esclavas de la tendencia a lo declamatorio o platónico. Dejando aparte la circunstancia de que hablar de libertad idelógica o de libertad de expresión del menor puede llevar a situaciones de verdadera caricatura, el jurista no puede dejar de sentir alguna frustración cuando ve cómo en la civilizada Europa están siendo noticia, hoy mismo, casos de flagrante atropello a la dignidad del menor. Hace pocos días, cuando se escriben estas líneas, que Bélgica se ha visto conmocionada por la mayor manifestación popular de su historia como consecuencia del descubrimiento de una red de paidofilia contra la que los mecanismos jurídicos y procesales parecen ser insuficientes. Y en España, también en las últimas semanas, estamos viendo - con consternación - cómo las leyes penales vigentes no bastan para 
hacer frente a una operación de pornografía infantil sutilmente tramada por medio del Internet.

De otro lado, hablar de los derechos del niño puede resultar una ironía si no se afronta decididamente una política legislativa de protección de la familia. Cierto es que el menor es hoy víctima de modos de vida que el Derecho no gobierna, pero no puede dudarse que un adecuado régimen fiscal, una oportuna reglamentación del trabajo de la madre fuera del hogar, e incluso medidas legales sobre la llamada tercera edad, pueden amortiguar los desastrosos efectos (cuyas consecuencias puede lamentar la humanidad) de niños con escaso contacto con sus padres, o privados de la enriquecedora relación con los abuelos; o - por eso mismo - sometidos a un régimen escolar que quizá les proporcione «información» (en el mejor de los casos), pero que desde luego no parece el adecuado para darles «humanidad».

10. También merece mención, por cuanto constituye en muchos casos una singular valoración de la persona desde el punto de vista jurídico, el conjunto de novedades legislativas subsumibles en lo que CARBONNIER denominó, muy gráficamente, como «tránsito del hecho al Derecho».

En este punto, debe ser señalada la relevancia que hoy se atribuye en el Derecho positivo a las llamadas «uniones de hecho», esto es, a las situaciones de convivencia more uxorio, asimiladas a las matrimoniales cuando quedare acreditada una suficiente estabilidad.

11. En otro orden de cosas, pero dentro del mismo capítulo, podría darse cabida a nuevas regulaciones que, arrancando de conquistas científicas muy recientes, responden al propósito de satisfacer necesidades, intereses o simplemente deseos del individuo. Por lo que bien puede decirse que se trata de normas vinculadas al valor que la persona tiene a los ojos del Derecho.

Son ejemplo de esto último leyes como la española de 27 de octubre de 1979 sobre extracción y transplantes de órganos, la de 22 de noviembre de 1988, sobre reproducción asistida humana, la de 28 de diciembre de 1988, sobre donación y utilización de embriones y fetos humanos o de sus células, tejidos u órganos, y la de 29 de octubre de 1992, sobre regulación del tratamiento automatizado de datos de carácter personal.

En relación con las dos leyes de 1988 que acabo de citar, por cierto, es digno de resaltarse cómo con ellas se persiguen objetivos loables, porque en su raíz se halla la persona. Pero no sin dejar de advertir que también desencadenan mecanismos jurídicos potencialmente peligrosos para el individuo. Por ejemplo, como consecuencia de la degradación del concepto de padre, madre o hijo, o — lo que todavía es más grave- a causa 
de una contemplación puramente biológica y no ética del embrión o el feto humano.

Casos como los que he mencionado sirven para poner el acento en otro aspecto: el especial cuidado que el Derecho civil ha de tener para que los avances tecnológicos (en principio pensados para servir a la persona) no vayan a redundar en deterioro o incluso atropello de su dignidad. Considero que es éste uno de los grandes desafíos con los que hoy se topa el civilista, tentado, de una parte, por buscar instrumentos jurídicos para la satisfacción de las apetencias humanas; pero sujeto, de otro lado, al riesgo de que dar rienda suelta a la imaginación jurídica (valga la expresión) conduzca a desenlaces moralmente dudosos, si no grotescos e incluso inhumanos.

En este punto no puedo silenciar mi opinión. Para ello, tomo como punto de partida una afirmación que puede parecer chocante por lo que luego diré: la de que todos los deseos humanos (sin excepción) merecen mi respeto, en tanto en cuanto no pretendan causar daño a otro. Por eso, respeto el deseo de la mujer que, no pudiendo sobrellevar un embarazo, busca la «maternidad» mediante el procedimiento de utilizar una madre «portadora» (la maternidad subrogada). O el deseo de la viuda que, años después de la muerte de su marido, desea ser inseminada con su esperma, debidamente conservado hasta entonces (el famoso caso Parpalaix de Francia, hace 12 años). Respeto también el deseo de tener un hijo varón, rubio, con ojos azules y de no menos de 1,70 metros de altura en la adolescencia. Y puesto a respetar, lo hago incluso con el deseo (se me admitirá la palabra extravagancia, aunque no sea más que en su sentido etimológico) del varón que busca su propio embarazo, cosa que al parecer es posible.

Respeto también, cómo no, una ciencia que puede llegar a hacer (como se ha puesto de relieve por algún autor) que una criatura tenga cinco padres: dos padres «sociales» (la pareja comitente o que hace el encargo), dos padres genéticos y una madre subrogada que lleva a término el embarazo.

Pero salvados todos estos respetos, no puedo dejar de decir algo más.

a) Me resisto a que se afinque entre nosotros la idea de que la ley puede (o debe) satisfacer todos los propósitos, objetivos y hasta caprichos humanos. Me parece que mientras no sepamos todos que una cosa es desear algo y otra tener derecho a ello, la humanidad no va por buen camino. Ni en esta cuestión ni en otras muchas. Cualquier interés lícito puede merecer la protección de la ley, pero no a toda costa y a cualquier precio. Y desde luego, no existe el más mínimo argumento para defender que el interés por la paternidad artificial sea un derecho fundamental de la persona. 
b) La circunstancia de que el ser humano lleve a cabo incluso despropósitos en uso de su libertad, o la de que ocurran desgracias en la vida, no constituye argumento para que el Derecho legitime cualquier desenlace. La decisión de un moribundo, o un accidente, pueden hacer que un niño nazca sin padre, pero considero aberrante que la ley le «condene» a no tenerlo: como ocurre cuando se admite la fecundación de la mujer con material reproductor de su marido ya muerto.

c) Me llama la atención que las medidas jurídicas de protección del embrión se formulen de manera indirecta u oblicua, como si el embrión fuese sólo un instrumento. Creo que la lógica exigía que antes que nada se hubiese promulgado un «estatuto jurídico del embrión», porque parece claro que él es el bien más valioso de los que están en juego en todas estas prácticas.

d) Un hijo no puede ser frívolamente considerado como un «medicamento» para la «enfermedad» de una pareja ansiosa de paternidad.

e) Me asombra la desproporción entre la gran inquietud del legislador por la infertilidad de las parejas y la escasa preocupación del gobernante por sus causas. Del mismo modo que me admira que se haya dado vía libre a formas de reproducción artificial a troche y moche, sin haberse llevado a cabo estudios significativos sobre las particularidades del nacimiento y de la educación de los niños nacidos con ellas.

12. También puede ser citada —en línea parecida — la solución jurisprudencial (y en algunos casos incluso la regulación legal) de los problemas que se han dado en llamar de transexualidad, esto es, aquellos en que una persona pretende ser reconocida jurídicamente como de sexo distinto al biológico. Hay que hacer notar cómo en estos casos se suele acudir por los Tribunales a argumentos de piedad o conmiseración para con la persona que se halla en ese trance.

La sentencia del Tribunal Supremo español de 2 de julio de 1987 (la primera que accedió a la petición de un transexual) revela una cierta dosis de «compasión» hacia el demandante, al aludir al «irresistible sentimiento de pertenencia al sexo contrario, rechazo del propio y deseo obsesivo de cambiar la morfología genital». Y merece la pena recordar que la sentencia, al referirse al resultado de la intervención quirúrgica a que se había sometido el demandante, esto es, a su apariencia de hembra, dijo: «Será una ficción de hembra si se quiere, pero el Derecho también extiende su protección a las ficciones. Porque la ficción desempeña en el Derecho un papel tan importante como el de la hipótesis en las ciencias 
exactas. Una y otra son meras suposiciones que hay que admitir para legitimar determinadas consecuencias en orden a la verdad científica o de la justicia o utilidad social».

Por cierto, quiero traer a colación la sentencia de 30 de abril de 1996 del Tribunal de Justicia de las Comunidades Europeas en que se declara que el principio laboral de no discriminación es extensible a la persona que tiene intención de someterse o se ha sometido a una operación de cambio de sexo. La sentencia dice que cuando una persona en esas circunstancias es despedida por su empresa, recibe un trato desfavorable frente a las personas del sexo al que se consideraba que pertenecía antes de la citada operación.

13. Casos como los que he mencionado permiten, creo, una reflexión:

Del mismo modo que sobre las leyes de reproducción asistida o similares, no parece temerario decir que en el fondo se halla un sentido cristiano de la vida humana; en definitiva, el reconocimiento de lo mucho que necesita la persona de los demás (e incluyo el Derecho) en sus fragilidades, en sus limitaciones y en sus aspiraciones.

No obstante, cuando pensamos en los despropósitos a que algunas normas de este tipo pueden conducir, cuando vemos ciertos modos de procreación que hacen pensar que las leyes están más cerca de la zoología que de la humanidad, cuando oímos una y otra vez del «matrimonio» entre una persona y otra transexual del mismo sexo genético, o cuando los medios de comunicación nos dan cuenta del propósito de dos mujeres de tener un hijo común, quizá fuera bueno recordar una frase de CHESTERTON que me parece genial. Escribió el autor inglés que «el mundo está lleno de ideas cristianas que se han vuelto locas».

14. El Derecho de daños es terreno abonado o, si se quiere, excelente banco de pruebas para calibrar el grado de tutela dispensada a la persona por el ordenamiento civil.

a) A este respecto, y con independencia de lo que luego diré sobre leyes especiales cuyo objetivo es la defensa de ciertos valores del ser humano, creo que es interesante advertir que la persona se halla en la raíz de un fenómeno de enorme magnitud que han conocido las últimas décadas.

Me refiero a la orientación jurisprudencial que, dando un giro copernicano sobre lo que todavía a mediados de este siglo se consideraba obvio, ha sentado la doctrina de que, producido un hecho dañoso, no es la víctima la que tiene que probar la culpa del presunto responsable, sino al revés, es éste quien tiene que acreditar que empleó en su actuación toda la diligencia precisa para evitar el resultado lesivo. La presunción de culpa del agente y la 
consiguiente inversión de la carga de la prueba han adquirido carta de naturaleza en la jurisprudencia española y en la de casi todos los países europeos.

No quiero insistir en el fenómeno, por bien conocido; pero sí aventurar la tesis de que este cambio de orientación jurisprudencial tuvo, en su origen, un «móvil piadoso» de los Tribunales hacia la persona. Es innegable que hoy se aplica el nuevo criterio a todo tipo de daños, no sólo los que llamamos personales o corporales, pero el análisis de la jurisprudencia europea al respecto mueve a pensar que la médula de la nueva orientación se halla en el designio judicial de procurar la reparación del daño sufrido por el individuo en su persona. Es significativo, en el caso español, que las sentencias precursoras se dictaran en casos en que estaba en juego el interés de los más débiles, esto es, de quienes - de haberse seguido la interpretación tradicional, que por otra parte es la que fluye del texto legal civil y de las reglas procesales sobre el onus probandi- habrían visto frustrada su esperanza de ser indemnizados.

Dicho de otro modo: tengo para mí que esa revolucionaria línea jurisprudencial de que hablo, hoy ya definitivamente implantada para todo tipo de daños, tuvo su origen en el propósito de facilitar el éxito de demandas encaminadas a dar satisfacción a los daños sufridos por la persona, fueran físicos, morales, o ambos a la vez.

b) También es menester tener en cuenta que las leyes que han instaurando regímenes de responsabilidad objetiva lo han hecho, sobre todo, con el fin de reparar con tan ventajoso criterio los daños causados a la persona. No es necesario pormenorizar detalles, pues basta recordar, en lo que se refiere al Derecho español y a otros ordenamientos europeos, las disposiciones legales en materia de daños derivados de la circulación de vehículos de motor, de la navegación aérea, de la caza, etc.

Recientemente hemos tenido en la Unión Europea una expresión muy particular de este fenómeno, como consecuencia de la promulgación de la Directiva comunitaria de 25 de julio de 1985 sobre responsabilidad civil por daños causados por productos defectuosos. Tanto la propia Directiva como las leyes nacionales de transposición de la misma (la española se dictó el 6 de julio de 1994), someten al sistema de responsabilidad objetiva los daños causados a la persona, excluyendo (salvo excepciones insignificantes) los producidos sobre cosas.

c) En el mismo plano del Derecho de la responsabilidad civil, por otra parte, muchas están siendo las novedades que depara la casuística jurisprudencial. Me detengo brevemente, por ejemplo, en las ya relativamente numerosas reclamaciones judiciales derivadas de lo que podríamos llamar «un nacimiento indeseado». Se trata de las acciones, abundantísimas en Estados Unidos, que en el mundo anglosajón se conocen como wrongful conception, wrongful birth y wrongful life. Son expresio- 
nes del alto grado de sensibilidad que la persona ha llegado a tener sobre sus propios valores físicos y morales; y a la vez, de la respuesta que el Derecho da a esa sensibilidad.

Menudean ahora en Europa demandas formuladas como consecuencia del nacimiento de un hijo no deseado, pero sano, fruto de un error médico en ligaduras de trompas o vasectomías. También las demandas en que los actores, padres de una criatura nacida con una enfermedad congénita, reclaman indemnización por el hecho de que un médico erró en el diagnóstico genético prenatal, impidiendo así el recurso al aborto; o incluso porque el profesional de la Medicina no advirtió a los padres sobre la conveniencia de efectuar tal diagnóstico. Y no faltan tampoco las demandas en que quien reclama es el propio hijo, aquejado de una dolencia genética, que invoca el daño constituido por una vida doliente y atormentada; en otras palabras, que alega un supuesto «derecho a no haber nacido» $\mathrm{u}$ otro no menos original «derecho a nacer sano».

Aquí tendríamos que volver de nuevo a la frase de CHESTERTON, recordando cómo al amparo de estas acciones se han llegado a plantear en Estados Unidos pintorescas reclamaciones (los llamados pleitos «de vida insatisfactoria»), en las que el actor alega el trauma emocional resultante de haber nacido de una relación ilegítima entre los padres. De ahí a demandar por haber nacido de un determinado color, o en un hogar pobre, no hay más que un paso.

15. Todo lo que venimos diciendo en el terreno de los principios es patente también en lo que podríamos llamar la «fenomenología» del ejercicio de los derechos de la persona.

Cito, simplemente a modo de ejemplo, el impacto formidable que ha tenido en España la Ley orgánica de 5 de mayo de 1982, sobre la protección civil del derecho al honor, a la intimidad personal y familiar y a la propia imagen. La Ley ha acuñado el concepto de «intromisión ilegítima» en los derechos objeto de tutela, acudiendo a un sistema de «antijuridicidades tipificadas». Pues bien, a su amparo se han producido y se siguen produciendo abundantísimas reclamaciones judiciales, con una casuística florida y todavía hace unos pocos años inimaginable. Tan notable proliferación de demandas por atentado real o supuesto a la persona permitiría decir (por utilizar una metáfora que en el pasado apliqué a los pleitos en materia de consumo) que ha despertado la conciencia dormida del ciudadano. Es decir, que ha sido esta Ley la que ha excitado el instinto natural de autoestima y de autodefensa.

16. Creo que no me equivoco al decir que nunca como hoy ha visto la persona tan tutelados por el Derecho civil sus valores, los bienes de su esfera física y síquica, sus sentimientos e incluso sus apetencias. 
Pero, como toda moneda, ésta tiene su reverso. Un reverso en cuyo fondo quizás se encuentre lo que, según he dicho en alguna ocasión, constituye una de las características del tiempo presente y probable explicación de muchos de los conflictos jurídicos que desfilan ante nosotros.

Me refiero al hecho de que el hombre de hoy no se resigna a sufrir contrariedades sin creer (digo creerlo de verdad) que alguien tiene que responder de todas sus desventuras. No hace mucho que, ante cualquier tipo de desgracia, pensábamos que era la fatalidad o la providencia las que nos la tenían reservada. Pero hoy no. Quizá (entre otras cosas) como consecuencia de lo que nos inculca la educación que recibimos, buscamos un culpable de lo que nos aflige o, simplemente, de lo que nos incomoda o desagrada.

Vemos así cómo con frecuencia se produce una auténtica «explotación» (en el sentido económico) de los derechos de la persona. Se multiplican las demandas en busca de dinero, como dicen los autores norteamericanos. Y contemplamos - a veces atónitos - cómo se expresa la codicia al socaire de los valores más respestables del individuo. Considero que no es exagerado decir que vivimos un tiempo particularmente apto para una grosera y descarada mercantilización de los bienes de la personalidad.

Delicada y difícil es la tarea de los Tribunales para discernir debidamente y distinguir entre las demandas realmente legítimas, razonables, y las que sólo buscan una infundada o desproporcionada reparación de un valor personal que, a veces, la propia víctima ha sido la primera en depreciar o envilecer.

17. No puedo silenciar una cuestión que hoy constituye, a mi entender, una de las más delicadas, pero a la vez insoslayable, de las que rodean a la tutela jurídica del individuo.

Me refiero a la valoración del daño a la persona, esto es, a los criterios que deben presidir la actuación de los Tribunales al fijar la cuantía de las indemnizaciones por daño físico o moral. En íntima conexión con este asunto está el constituido por la definición o delimitación de los conceptos o capítulos que debe englobar la reparación del daño a la persona, del daño corporal o del daño a la salud como gustan de decir los autores italianos.

a) El problema que apunto es hoy, en mi opinión, uno de los «temas estrella» del Derecho de daños. La bibliografía sobre la materia es abundantísima. Me parece que supera a cualquier otra en la doctrina actual de la responsabilidad civil. De otro lado, la inquietud ha pasado al primer plano de las soluciones judiciales, que nunca como ahora se muestran tan inquietas por tratar de persuadir sobre el porqué de sus condenas. 
Y las leyes no han escapado a esta preocupación. Téngase presente que en España se acaba de establecer (por Ley de 8 de noviembre de 1995) una notable modificación de la vulgarmente conocida como Ley del automóvil. Se instaura en ella un régimen tasado de indemnizaciones por daños personales; esto es, una fórmula de indemnizaciones vinculantes (por medio de tablas o baremos) que los órganos judiciales no pueden superar. Por decirlo de otro modo, ha desaparecido (o por lo menos se ha amortiguado muy sensiblemente) el clásico principio de libre y discrecional valoración del daño por parte de los jueces en caso de muerte, de lesiones permanentes y de incapacidades temporales. En suma -y como ya manifesté cuando la Ley era sólo un proyecto- estamos en presencia de una auténtica «revolución» en el Derecho de la responsabilidad civil; una verdadera conmoción de principios que hasta ahora habíamos tenido por intocables.

En el mismo plano legal a que ahora me refiero, recuérdense los numerosos recursos de inconstitucionalidad planteados en Estados Unidos contra leyes estatales (o resoluciones judiciales, pero constitutivas de leading cases) que establecieron topes indemnizatorios en casos de daños a la persona y dentro de determinados sectores de actividad; por ejemplo, en supuestos de mala praxis médica.

b) Uno se siente un tanto cohibido cuando habla sobre esta materia, porque parece como si se estuviera incurriendo en una grosería o cometiendo un acto de irreverencia hacia el ser humano.

No obstante, no conviene caer en hipocresías. Decimos con frecuencia que la vida, la salud, el honor, etc., no tienen precio, pero se da la circunstancia de que todos los días los estamos sometiendo al metro pecuniario en la práctica del Derecho.

Ahora me limito a apuntar algunas reflexiones sobre la cuestión.

La reparación de un daño personal tan cualificado como es el daño moral (entendida esta expresión en su sentido más amplio, en el que tienen cabida los dolores físicos, las aflicciones, las frustraciones, los complejos y los sentimientos) no puede ser otra cosa, desde el punto de vista del Derecho, que un «consuelo», como se ha dicho en afortunada expresión. Otra, no menos afortunada, es la de que la total indemnización del daño moral constituye «una ilusión».

Parece, leyendo los clásicos franceses, que la reparación en dinero del daño moral fue un recurso al que se acudió para salvar las dificultades que a veces ofrecía la prueba del daño patrimonial sufrido por la pérdida de quien mantenía a la familia: «valorar» el dolor sufrido por los hijos era una forma de aliviar también el daño económico derivado de la muerte del padre.

Otra observación que formular es la de que la valoración del daño moral tiene que someterse a cánones o criterios de cierta objetividad. De 
no ser así, padece la igualdad ante la ley: son conocidas las a veces espectaculares diferencias entre las condenas de unos u otros Tribunales, para casos similares. También queda en entredicho el principio de seguridad jurídica, puesto que forma parte de él la posibilidad de hacer una previsión razonable de lo que los Tribunales van a decidir ante un caso determinado. Por ello mismo, aumenta artificialmente la litigiosidad, al ser difíciles los arreglos amistosos.

Yo no quiero caer en los excesos a que puede conducir un mal entendido «análisis económico del Derecho». Ni, desde luego, incurrir en el riesgo de que la cuestión que me ocupa sea una coartada o un disfraz de los intereses de los grandes poderes económicos. Pero no puedo dejar de manifestar mi convicción, argumentada en un reciente trabajo, de que en este punto es necesario poner un poco de orden. Y, desde luego, me amparo sin recato en autoridades que se han expresado en el mismo sentido: basta recordar pasajes de ilustres especialistas franceses como TUNC y VINEY.

La cuestión, como decía, está ahí y parece inexcusable abordarla seriamente. Ya sea en virtud de criterios jurisprudenciales que persuadan por su autoridad, ya por medio de normas legales.

c) Por referirme ahora a la situación en España, habrá que ver las enseñanzas que vaya a proporcionar la recién estrenada Ley de 1995. Con todo, creo que por la propia originalidad del sistema no es impertinente que exprese aquí mi impresión en torno a lo que sobre la nueva regulación se piensa en los ambientes jurídicos de mi país.

Es muy atrevido emitir juicios al respecto, pero me parece que entre los jueces el sistema no ha sido bien recibido. Es claro que en ellos existía una cierta zozobra en el sistema anterior, de libre y discrecional valoración, pero es posible que la imposición legal de indemnizaciones tasadas haya producido en muchos juzgadores la sensación de que se les recortaba la noble función de resolver conflictos. Sentimiento que, de ser así, tendría explicación, habida cuenta del derecho y del deber del juez de defender su «independencia», aunque esta palabra no se entienda en su acepción jurídica estricta.

Entre los abogados parece predominar la actitud crítica y de reparos al sistema, que acaso pudiera estar influida por la idea de que la nueva fórmula menoscaba su función de defender los intereses de sus clientes (hablo, desde luego, de clientes víctimas). Esta actitud se hallaría justificada en la medida en que el nuevo sistema reduce drásticamente la posibilidad de atender las particularidades de cada caso concreto, pues es evidente que ahora predomina el «encasillamiento» en grupos no muy numerosos. Por otro lado, parece también claro que la nueva fórmula legal ha supuesto una disminución (en términos globa- 
les) de las cuantías de las indemnizaciones percibidas. Es evidente que pueden entrar también en juego consideraciones de orden económicoprofesional.

En el mundo doctrinal aumentan las voces que manifiestan reservas (si no serias invectivas) contra el nuevo estado de cosas.

No tengo datos fiables sobre si el nuevo sistema ha conseguido uno de sus objetivos, cual es el de fomentar las soluciones transaccionales, esto es, disminuir la litigiosidad. Pero, por referencias de algún compañero especializado en la materia, parece que esa consecuencia se ha producido significativamente. Lo que también parece claro es que se ha abreviado de forma considerable la tramitación de los siniestros por parte de las compañías de seguros.

Están por ver, de otro lado, los efectos que en el ámbito macroeconómico va a producir la nueva normativa. Estoy pensando, por ejemplo, en si va o no a influir en la cuantía de las primas del seguro, tanto obligatorio como voluntario.

Yo manifiesto la opinión de que, valga la expresión, la «filosofía» del sistema es acertada. Del mismo modo, he formulado en otro lugar mis reparos hacia ciertos extremos del mismo, alguno de ellos de considerable importancia.

Esta experiencia ha convertido a España en un país verdaderamente innovador. Algunos dirán que para bien, y otros que para mal. Lo que parece evidente es que el nuevo sistema, debidamente perfeccionado, puede ser ejemplo para otros ordenamientos.

18. La historia del Derecho de la persona ofrece un panorama de vaivenes o movimientos pendulares (¿los corsi e ricorsi de que hablaba VICO?), a la vez que — contemplada en un momento dado- está plagada de claroscuros.

Mas, como decía al principio, parece que no es atrevido a decir que el Derecho de la persona en Europa, ahora, vive momentos de apogeo. Es significativo $-\mathrm{y}$ esperanzador - que los civilistas de nuestro continente hayan vuelto la mirada a quienes en el pasado, casi clamando en el desierto, reivindicaban para el Derecho civil la función de «escudo del individuo contra los abusos de poder de las agrupaciones» (así de gráfico fue BONNECASE hace ya décadas).

Al hablar de estas cuestiones no es posible silenciar un dato que estimo muy significativo. Me refiero al hecho de que cuando en el libro Intervista sul diritto privato (Padua, 1988) varios juristas italianos fueron preguntados sobre cuál habría de ser, a su juicio, la misión del Derecho privado de nuestro tiempo, la mayor parte de ellos no dudó en afirmar que su función prioritaria tenía que ser la tutela de la persona. Promovió 
aquella «entrevista» un prestigioso profesor italiano, IRTI, que por su parte, en otra obra, ha dejado escrito: «El civilista es un intelectual militante para la defensa del individuo».

Todo esto debe hacerse verdad en un continente como el nuestro, que se considera desarrollado porque ha alcanzado cotas razonables de bienestar y de educación para sus ciudadanos; pero es particularmente deseable en tantos otros lugares del planeta que no han logrado todavía el objetivo de verdadera igualdad en auténtica libertad. 


\title{
LA EXTRAORDINARIA Y URGENTE NECESIDAD EN EL REAL DECRETO-LEY 5/1996, DE 7 DE JUNIO, DE MEDIDAS LIBERALIZADORAS EN MATERIA DE SUELO Y DE COLEGIOS PROFESIONALES
}

\author{
José Luis Avila Orive \\ Profesor Titular de Derecho Administrativo de la Universidad de Deusto
}

Sumario: I. Introducción. II. El presupuesto habilitante: la extraordinaria y urgente necesidad. II.1. Lo necesario. II.2. Lo extraordinario. II.3. Lo urgente. II.4. El examen del Real Decreto-Ley 5/1996, de 7 de junio, de medidas liberalizadoras en materia de suelo. II.5. Los efectos de la nulidad del cuestionado Decreto-Ley. II.6. Los límites materiales.

\section{Introducción}

Ciertamente, la promulgación de este Real Decreto-Ley ha supuesto una notable sorpresa y desconcierto en el mundo urbanístico. No por la pretensión reformadora del nuevo Gobierno, cuyas discrepancias con el ordenamiento urbanístico vigente eran conocidas, sino por el instrumento utilizado, la pretendida urgencia de que se le acompaña y el ámbito y extensión de la propia reforma. A la situación de incertidumbre existente, debida a las impugnaciones contra la Ley 8/1990 y el Decreto Legislativo 1/1992, ahora se le añade la que representa la citada norma jurídica con fuerza de Ley.

Los efectos que este Real Decreto-Ley produce pueden sistematizarse en torno a cuatro grandes apartados, como son la terminación de la distinción entre suelo urbanizable programado y no programado, la modificación del régimen de aprovechamiento y cesión de suelo a los Ayuntamientos, la reducción de los plazos de tramitación del planeamiento y la modificación de la Ley 7/1985 de Bases de Régimen Local. En cualquier caso antes de abordar estos efectos, resulta conveniente realizar un análisis del grado de cumplimiento de los parámetros constitucionales por parte del Real Decreto-Ley. 


\section{El presupuesto habilitante: la extraordinaria y urgente necesidad}

La fórmula contenida en el artículo 86.1 de la Constitución ha sido objeto de análisis y pronunciamientos por parte del Tribunal Constitucional, y de estudio doctrinal, de tal modo que hoy están básicamente delimitados los contornos de esas disposiciones legislativas provisionales que toman forma de Decretos Leyes. Es necesario llevar a cabo un ejercicio de contraste con esos límites a fin de comprobar su respeto o vulneración por el Decreto-Ley de medidas liberalizadoras en materia de suelo y colegios profesionales.

\section{II.1. Lo necesario}

El citado artículo 86.1, como es sabido, establece: «En caso de extraordinaria y urgente necesidad, el Gobierno podrá dictar disposiciones legislativas provisionales que tomarán la forma de Decretos-Leyes...». Realmente en la transcrita cláusula se aprecia el carácter excepcional de tal vía de producción de normas jurídicas con fuerza de Ley, al margen del procedimiento legislativo ordinario. Sin embargo, la excepcionalidad, como se podrá comprobar, no se deduce de la mayor o menor versatilidad de dicha norma para poder ser utilizada por el Gobierno, en función del cumplimiento de los requisitos impuestos ex Constitutione, sino de la posibilidad de crear normas jurídicas con valor de Ley, al margen del procedimiento legislativo ordinario, siempre que se cumplan los límites o requisitos que la Constitución establece ${ }^{1}$. Dicho con otras palabras su carácter excepcional no obedece a que sea utilizado en raras ocasiones, aunque es verdad que si esto fuese así se fortalecería el entendimiento de la excepcionalidad, sino a que su utilización se aparta de la regla general, que es el procedimiento legislativo ordinario. Como más adelante se verá, el carácter de la necesidad habilitante implica la consideración del Decreto-Ley por el Tribunal Constitucional, como un instrumento normativo no totalmente excepcional, pero caracterizado, sin duda, por este elemento.

Alguna doctrina ha apreciado una cierta evolución en la jurisprudencia constitucional, respecto a la valoración de la necesidad habilitante para poder dictar un Decreto-Ley, fijándose en reflexiones que el Tribunal realizaba en torno a la excepcionalidad de la disposición de tal instru-

\footnotetext{
1 Santolaya Machetti, P., en El Régimen constitucional de los Decretos-Leyes, Tecnos, 1988 , p. 107, considera que «el Decreto-Ley se configura no como un instrumento excepcional, sino como algo no normal».
} 
mento. Es el caso de Soriano ${ }^{2}$, que entiende que en la primera sentencia del Tribunal Constitucional al respecto (29/1982, de 31 de mayo) se aprecia el reconocimiento del carácter excepcional del Decreto-Ley en el sistema de fuentes del derecho establecidas en la Constitución, debido fundamentalmente a lo que expresa en su Fundamento Jurídico $1 .^{\circ}$, mientras que en la segunda sentencia (6/1983, de 4 de febrero) queda diluido ese carácter excepcional. Dice lo siguiente la primera de las sentencias citadas:

«El Gobierno podrá dictar normas con rango de Ley (...), en los supuestos de extraordinaria y urgente necesidad (decretos-leyes), pero esta posibilidad se configura, no obstante, como una excepción al procedimiento ordinario...».

Sin embargo, el Tribunal declara en el mismo párrafo, recordado también en sentencias posteriores, que la reconocida posibilidad de utilización del Decreto-Ley «está sometida en cuanto a su ejercicio a la necesaria concurrencia de determinados requisitos que lo legitiman». Parece, por tanto, más conveniente centrar la atención en el grado y clase de cumplimiento de los requisitos que es exigido por el Alto Tribunal ${ }^{3}$, que en la mera formulación genérica acerca de su excepcionalidad.

Siguiendo este criterio, no pueden apreciarse en la jurisprudencia constitucional intenciones dispares respecto a la funcionalidad del Decreto-Ley, sino más bien una definición sucesiva, aún sin terminar, de su ámbito y límites. Cuestión distinta es la discrepancia que en la doctrina ha quedado plasmada, respecto a la postura adoptada por el Tribunal Constitucional ${ }^{4}$.

El uso excepcional del Decreto-Ley es legítimo cuando su ejercicio se verifica dentro de los límites que la Constitución establece. En este sentido se manifiesta desde el principio el Tribunal constitucional en su Sentencia 29/1982, de 31 de mayo:

2 SoRiano, J.E.: «Los Decretos-Leyes en la Jurisprudencia Constitucional española», $R A P$, núms. 100-102, 1983, pp. 454-455.

${ }^{3}$ Hay que expresar, no obstante, que el Tribunal Constitucional no abandona su consideración acerca de la excepcionalidad que envuelve la figura del Decreto-Ley. En su sentencia 29/86, de 20 de febrero, señala lo siguiente:

...«dada la excepcionalidad con que nuestra Constitución regula la figura del Decreto-Ley, sólo cuando concurra una causa suficiente de necesidad, adjetivada por las circunstancias de extraordinaria urgencia, puede el Gobierno utilizar este instrumento normativo...» (FJ 2).

${ }^{4}$ Vid. Salas, J.: «Los Decretos-Leyes en la teoría y en la práctica Constitucional», en Estudios sobre la Constitución Española. Homenaje al profesor Eduardo García de Enterría, Cívitas, 1991, pp. 273 y ss.

Astarloa Huarte-Mendicoa, I.: «Teoría y práctica del Decreto-Ley en el ordenamiento español», RAP, núm. 106, pp. 117 y ss.

PÉREZ ROYO, J.: «La distribución de la capacidad normativa entre el Parlamento y el Gobierno», en El Gobierno en la Constitución española y en los Estatutos de Autonomía, Diputación de Barcelona, 1985, p. 141. 
«Nuestra Constitución limita en un doble sentido la facultad excepcional que atribuye al Gobierno para promulgar, en forma de DecretoLey, normas con fuerza de Ley. Esta limitación viene dada, de una parte $(\ldots)$, por la exclusión de determinadas materias (...), que en ningún caso pueden ser objeto de regulación mediante Decreto-Ley; de la otra, por la conexión establecida entre esta facultad legislativa excepcional y la existencia de un presupuesto habilitante concreto: el caso de extraordinaria y urgente necesidad» (FJ 3$)$.

A pesar de la competencia de los órganos políticos, concretamente del Congreso de los Diputados, para fiscalizar, a través de su apreciación, la concurrencia del presupuesto habilitante para el ejercicio de la facultad legislativa excepcional, es competencia del Tribunal Constitucional rechazar la definición realizada por los órganos políticos en supuestos de uso abusivo o arbitrario de la figura del Decreto-Ley. Sin embargo, esta operación no tiene los lindes muy claros, de tal manera que el Tribunal Constitucional corre un cierto riesgo de entrar con sus apreciaciones en el terreno del juicio de oportunidad reservado al ámbito político.

En este sentido, el Tribunal Constitucional ha determinado las líneas básicas de la necesidad que debe concurrir para que el ejercicio de la posibilidad constitucional sea legítima.

En primer lugar, la necesidad exigible no es absoluta, entendiendo por tales aquellas en que puede existir un peligro inminente para el orden constitucional, de tal modo que la regulación a través de Decreto-Ley no es permitida sólo en forma totalmente excepcional. Por ello el Tribunal Constitucional señala que la solución adoptada por la Constitución es flexible y matizada, en cuanto se exige para su uso la concurrencia de una necesidad relativa respecto de situaciones concretas relacionadas con objetos gubernamentales que, por razones que son difíciles de prever, exigen una acción normativa inmediata, para la que no son servibles los procedimientos ordinario o incluso el de urgencia, de elaboración de las leyes. En este sentido, se considera que la Constitución contempla el Decreto-Ley como un instrumento que puede utilizarse para dar respuesta a las perspectivas cambiantes de la vida actual $^{5}$ y alcanzar los objetivos marcados para la gobernación del país.

La definición expansiva del campo así reservado al Decreto-Ley por la Constitución según el Tribunal Constitucional, para la satisfacción de necesidades relativas, configura un instrumento normativo de respuesta a cuestiones que se manifiestan en nuestro tiempo con carácter ordinario, a FJ.3.

SSTC 6/83 de 4 de febrero, FJ.5; 29/86, de 20 de febrero, FJ.2; 60/86 de 20 de mayo, 
la vez que admite la existencia de un ámbito de oportunidad política y técnica en la elección de dicha respuesta, sobre la que el Tribunal Constitucional, como ya ha dejado sentado desde la primera de sus sentencias al respecto (29/1982, de 31 de mayo, FJ 5), no tiene competencia para pronunciarse.

En segundo lugar, el carácter extraordinario con el que se adjetiva la necesidad en la Constitución, no proviene de la naturaleza del ámbito, que, como ha quedado expuesto, obedece a necesidades relativas provenientes de los objetivos de la gobernación del país, sino fundamentalmente de la dificultad o imposibilidad de prever las circunstancias que requieren una respuesta normativa inmediata.

En tercer lugar, la urgencia que debe acompañar a la necesidad, implica la inidoneidad del procedimiento legislativo ordinario o del procedimiento de urgencia para responder adecuadamente a las necesidades planteadas.

\section{II.2. Lo extraordinario}

Las necesidades sociales ordinarias son, o al menos deben ser, referencia e inspiración obligada de la particular perspectiva de los diferentes programas políticos. En este sentido, las leyes suponen un intermedio necesario para que el Gobierno pueda aplicar su programa político, en aras a la satisfacción de dichas necesidades y por tanto, el instrumento ordinario a su servicio. Las necesidades ordinarias componen el complejo ordinario de objetivos que el Gobierno pretende obtener. La identificación, determinación y formulación de dichas necesidades implican un ejercicio de reflexión, búsqueda y previsión que confluye y caracteriza al programa político. Consiguientemente el procedimiento legislativo ordinario es el cauce de incorporación de los fines que satisfarán, a través de su ejecución, las necesidades que son su presupuesto.

El Decreto-Ley pretende cubrir un espacio no cubierto por la Ley como instrumento jurídico de satisfacción de necesidades sociales ordinarias. Ese espacio está configurado por las necesidades que no pueden ser objeto de previsión, o que pueden ser difícilmente previsibles, pero que existen y se manifiestan de un modo ciertamente sorpresivo que requiere una acción imnediata.

Resulta evidente que, en ocasiones, la pericia de quien ostenta la responsabilidad de brindar esas respuestas normativas, influye notablemente en el significado y alcance de la imprevisibilidad, de tal modo que lo que para algunos es absolutamente imprevisible, para otros es una situación vista a lo lejos y por tanto esperada. En cualquier caso, parece necesario 
ponderar en cada supuesto, el grado de razonable imprevisibilidad que concurre a fin de reconocer la legitimidad en el uso del Decreto-Ley.

El Tribunal Constitucional se ha hecho eco de este factor de dificultad o imposiblidad de previsión, así como de la concurrencia compleja de circunstancias que impiden acudir a la vía legislativa ordinaria, para justificar la existencia del presupuesto habilitante. Así:

...«la utilización del Decreto-Ley mientras se respeten los límites del artículo 86 de la Constitución, tiene que reputarse como una utilización constitucionalmente lícita en todos aquellos casos en que hay que alcanzar los objetivos marcados para la gobernación del país, que, por circunstancias difíciles o imposibles de prever, requieren una acción normativa inmediata o en que las coyunturas económicas exigen una rápida respuesta» (STC 6/1983, de 4 de febrero, FJ 5).

«Nuestra Constitución (...) ha contemplado el Decreto-Ley como instrumento del que es posible hacer uso para ordenar situaciones que, por razones difíciles de prever, reclaman una acción legislativa inmediata, en un plazo más breve que el requerido por la tramitación parlamentaria de las leyes. La justificación del Decreto-Ley podrá darse en aquellos casos en que por circunstancias o factores, o por su compleja concurrencia, no pueda acudirse a la medida legislativa ordinaria, sin hacer quebrar la efectividad de la acción requerida, bien por el tiempo a invertir en el procedimiento legislativo o por la necesidad de la inmediatividad de la medida» (STC 111/1983, de 2 de diciembre, FJ 6).

...«la utilización del Decreto-Ley, mientras se respeten los límites del art. 86 de la Constitución, tiene que reputarse como una utilización constitucionalmente lícita en todos aquellos casos en que hay que alcanzar los objetivos marcados por la gobernación del país, que por circunstancias difíciles o imposibles de prever, requieren una acción normativa inmediata o en que las coyunturas económicas exigen una rápida respuesta» (STC 29/1986, de 20 de febrero, FJ 2). Reproducido también en la STC 60/1986, de 20 de mayo, FJ 3.

Por tanto, no es posible una utilización legítima del Decreto-Ley sobre cuestiones o situaciones que son fácilmente previsibles, o peor aún, que son sobrada y acreditadamente conocidas. Esta clase de hechos entran dentro de lo que anteriormente se ha denominado como necesidades ordinarias, para las que la Constitución, cuando así se requiera, reserva el procedimiento legislativo ordinario. La excepcionalidad en el uso del Decreto-Ley, requiere una necesidad acompañada de los adjetivos extraordinaria y urgente, sin que se pueda prescindir de ninguno de los dos. Lo contrario sería admitir como causa habilitante la concurrencia de cualquier necesidad.

Pueden plantearse dudas acerca del grado de imprevisibilidad requerido para un uso legítimo del Decreto-Ley, sin embargo existen indicios 
racionales de previsibilidad que pueden desvirtuar la pretendida existencia del presupuesto habilitante. Como señala ASTARLOA HUARTEMENDICOA, la extraordinariedad y la urgencia «no son términos sinónimos, en cuanto aquélla no se refiere tan sólo al ámbito temporal, sino más bien a una valoración cualitativa de la necesidad, que viene así descrita como importante, grave e imprevisible, teniendo en cuenta que, si la gravedad admite complicada calificación jurídica, la previsibilidad puede deducirse de datos como la existencia de proyectos anteriores, negociaciones previas (...), proposiciones registradas en sede parlamentaria $\mathrm{o}$, en general, la valoración de los diversos antecedentes del tema» ${ }^{6}$.

La admisión de las denominadas necesidades relativas como ámbitos susceptibles de ser regulados mediante Decreto-Ley no implica la desaparición de la exigencia de urgencia y extraordinariedad, aunque la interpretación del Tribunal Constitucional de este presupuesto haya supuesto la identificación de esas necesidades. Dicho con otras palabras, no sólo debe reconocerse eficacia al presupuesto habilitante, para el caso de que la interpretación quede decantada hacia la defensa del uso totalmente excepcional del Decreto-Ley, sino que también tiene su virtualidad cuando los ámbitos permitidos a dicha norma con rango de ley son necesidades relativas ${ }^{7}$. En este sentido resulta apropiado traer a colación la apelación

6 Astarloa Huarte-Mendicon, I.: «Teoría y práctica del Decreto-Ley en el ordenamiento espanol», $R A P$, núm. 106, p. 119. El autor entiende que la consideración por parte del Tribunal Constitucional de las necesidades relativas que se deducen de los objetivos gubernamentales, identifica la idea de necesidad con las de conveniencia y comodidad, abriendo posibilidades ilimitadas al Decreto-Ley, sólo acotadas por la interdicción de la arbitrariedad proclamada en el 9.3 de la Constitución (pp. 122-123).

Sin embargo, parece posible la estimación de esas necesidades de carácter relativo, y a la vez el respeto de la extraordinaria y urgente necesidad establecida en la Constitución, como límite efectivo en la utilización del Decreto-Ley.

7 SaLAS, J., en «Los Decretos-Leyes en la teoría y en la práctica constitucional», en Estudios sobre la Constitución Española, Homenaje al profesor Eduardo García de Enterría, tomo I, pp. 274 y 275, postula la inconstitucionalidad de aquel Decreto-Ley que «de haberse presentado como proyecto de ley a través de alguna de las modalidades procedimentales indicadas [se refiere al procedimiento de urgencia, aprobación en comisión con competencia legislativa plena, tramitación en lectura única] hubiera podido convertirse en Ley en un plazo tal que la necesidad que pretendiera satisfacer se mantuviera en pie y no se hubieran producido graves perjuicios [el subrayado no es original] para los intereses públicos en el lapso de tiempo que medie entre la presentación de aquel proyecto y su promulgación como Ley». El hecho de que el Tribunal Constitucional se haya decantado por la llamada «necesidad relativa», supone, a su juicio, la adopción de una distinta línea interpretativa que desemboca en la disposición por parte del Gobierno de poder apreciar discrecionalmente la concurrencia de dicho presupuesto, reservando el control de esa apreciación al Tribunal Constitucional, sólo cuando sea claramente abusiva o contraria.

En similar sentido Pérez Royo, J.: «La distribución de la capacidad normativa entre el Parlamento y el Gobierno», en El Gobierno en la Constitución Española y en los Estatutos de 
de LAVILLA a la innecesariedad de sustentar los pronunciamientos jurisdiccionales del Tribunal Constitucional, en valoraciones que supongan «cierta atenuación del sentido y del alcance con los que el artículo 86 confiere potestades normativas excepcionales al Gobierno» ${ }^{8}$.

\section{II.3. Lo urgente}

Los márgenes de discrecionalidad con que cuenta el Gobierno para la definición del presupuesto habilitante ${ }^{9}$, alcanzan obviamente al concepto y significado de urgencia, pero en la misma medida que le afectan los límites que la Constitución establece a ese margen de definición.

La urgencia, como antes se ha manifestado, adjetiva y caracteriza a la necesidad, por tanto debe entenderse ligada a ella, de tal modo que la apreciación gubernamental respecto a su concurrencia, no debe basarse en su propia voluntad, sino en la adecuación a la satisfacción de la nece$\operatorname{sidad}^{10}$.

La jurisprudencia del Tribunal Constitucional establece una doctrina en torno a la urgencia, que, en línea con la excepcionalidad planteada en el artículo 86, concibe el Decreto-Ley como un procedimiento excepcional alternativo a otros procedimientos legislativos, cuya utilización no es posible por su falta de adecuación a las necesidades de inmediatez que son exigidas. En ese sentido señala lo siguiente:

«EL T.C. podrá, en supuestos de uso abusivo o arbitrario, rechazar la definición que los órganos políticos hagan de una situación determinada como caso de extraordinaria y urgente necesidad, de tal naturaleza que no pueda ser atendida por la vía del procedimiento legislativo de urgencia» (STC 29/1982, de 31 de mayo, FJ 3).

Autonomía, Diputación de Barcelona, 1985, p. 141. Astarloa Huarte-MendicoA, I.: «Teoría y práctica del Decreto-Ley...», op. cit., p. 123.

8 Lavilla, L.: «Sobre los Decretos-Leyes» en Libro Homenaje al Profesor J.L. Villar Palasí, Cívitas, Madrid, 1989, p. 621.

${ }^{9}$ Para examinar el alcance del presupuesto habilitante desde la distinción entre discrecionalidad y conceptos jurídicos indeterminados, pueden verse, entre otros: GARCÍA DE ENTERRÍA, E. y Fernández, T.R.: Curso de Derecho Administrativo, I, Cívitas, 1995, pp. 134 y ss. SAlas, J.: Los Decretos-Leyes en la Constitución Española, Cuadernos Cívitas, 1979, pp. 29 y ss. DE Отто, I.: Derecho Constitucional. Sistema de fuentes, Ariel, 1995, pp. 197-198.

Sobre la elaboración doctrinal de tales categorías jurídicas deben citarse GARCÍA DE ENTERRÍA, E.: «La lucha contra las inmunidades del Poder en el Derecho Administrativo», RAP, 1962, núm. 38 y SAInz Moreno, F.: Conceptos jurídicos, interpretación y discrecionalidad administrativa, Cívitas, 1976.

${ }^{10}$ Santolaya Machetti, P.: El régimen constitucional de los Decretos-Leyes, op. cit., p. 110 . 
...«no se fija un plazo perentorio para dictar tal regulación, que habría de ser inferior al necesario para tramitar la deslegalización como proyecto de Ley por el procedimiento de urgencia» (STC 29/82, de 31 de mayo, FJ 6).

...«situaciones concretas de los objetivos gubernamentales, que, por razones difíciles de prever, requieren una acción normativa inmediata en un plazo más breve que el requerido por la vía normal o por el procedimiento de urgencia para la tramitación parlamentaria de las leyes» (STC 6/83, de 4 de febrero, FJ 5). Reproducido en la STC 111/1983, de 2 de diciembre, FJ 6 y 60/1986, de 20 de mayo, FJ 3.

...«regula la figura del Decreto-Ley (...) como instrumento en cuanto a su fuerza equivalente a la Ley, y utilizable cuando una necesidad calificada por las notas de lo «extraordinario» y lo «urgente» reclama una acción normativa que, por lo ordinario, compete al legislador, pero que precisamente por esa necesidad, y no poder ser atendida por una acción normativa emanada de las Cortes Generales, se autoriza al Gobierno, con un carácter de provisionalidad hasta tanto obtiene la convalidación...» (STC 111/83, de 2 de diciembre, FJ 4).

De esta manera la legitimidad de la utilización del Decreto-Ley no sólo depende de la propia necesidad, sino en esta concreta cuestión, depende también del tiempo que haya de invertirse en los procedimientos legislativos ordinarios ${ }^{11}$ y por tanto de si éstos resultan remedios adecuados para la inmediatez requerida de la acción normativa.

En nuestro ordenamiento, no es posible separar, en lo que entendemos como acción normativa, el hecho mismo de la actuación normativa de la aplicación material de su contenido. O por lo menos no es posible hasta el punto de desvirtuar la noción de urgencia exigida.

Esta posibilidad planteada y criticada en la doctrina italiana (Espósito y Raveraira, respectivamente ${ }^{12}$ ), tiene dos manifestaciones, como se encarga de resaltar SANTOLAYA MACHETTI:

Una de ellas, la posibilidad de dilatar en el tiempo la aplicación del contenido del Decreto-Ley.

Otra, la concurrencia del Decreto-Ley para dar satisfacción a necesidades que se consideran urgentes, pero que han surgido con mucha anterioridad a su promulgación, bien atribuyéndole efectos retroactivos, o sin dicha atribución.

11 Sobre la falta de legitimidad de los Decretos-Leyes, cuando se basan exclusivamente en la tardanza del Parlamento puede verse Di Ciolo, V.: Questioni in tema de Decreti-legge, I, Giuffrè, Milano, 1970, p. 230, y PALADIN, L.: «Gli atti con forza di legge nelle presenti esperienze costituzionali», Giurisprudenza Costituzionale, 1974, 1, p. 1.520, consultados por Santolaya Machetti, P., en El régimen constitucional de los Decretos-Leyes, op. cit.

12 Espósito, C.: «Decreto-Legge», en Enciclopedia del Diritto, 1962, pp. 844-5 y RAVERAIRA, M.: «Il problema del sindacato di costituzionalit sui presupposti della "necesit" et “urgenza” dei Decretilegge», Giurisprudenza Costituzionale, 1982, I, pp. 1433 y ss. 
Para el caso concreto que se va a analizar (Real Decreto-Ley 5/1996, de 7 de junio), no interesan las consideraciones al respecto de la dilación temporal en la aplicación del contenido normativo correspondiente, ni la atribución de efectos retroactivos, pero sí el hecho de la declaración como urgentes de necesidades surgidas, y desafortunadamente todavía hoy existentes, con mucha anterioridad a la fecha en que se promulga el Real Decreto-Ley citado.

El Tribunal Constitucional no ha tenido hasta la fecha, la oportunidad de manifestarse sobre tal cuestión, pero resulta evidente que el conocimiento anticipado, exageradamente anticipado, de una necesidad social, provoca razonablemente su conversión en un argumento programático de carácter político, y consiguientemente en un objetivo gubernamental, que destruye la notas de imprevisibilidad y urgencia en el sentido exigido constitucionalmente.

Podría argumentarse que precisamente el hecho de que exista una situación de necesidad social, cuya solución todavía está pendiente, avala aún más la decisión del Gobierno de utilizar un instrumento excepcional que asuma el tratamiento y respuesta inmediata de tal necesidad. Sin embargo, esa concepción de la urgencia, no está cohonestada con el presupuesto habilitante que la Constitución exige, sino más bien con un sentido de urgencia relacionado con la voluntad gubernamental, que son cuestiones absolutamente distintas.

No es procedente excluir la relación entre necesidades sociales e idoneidad del procedimiento legislativo ordinario, y por consiguiente la utilización alternativa del Decreto-Ley para conseguir la promulgación de una serie de medidas de respuesta inmediata a tales necesidades, cuando éstas son reconocibles y reconocidas como un problema sentido y encajado en la sociedad a través del transcurso del tiempo. No es legítimamente posible el uso de dicho instrumento jurídico, cuando esas necesidades, largamente vividas como problemas sociales, han sido y están siendo objeto de tratamiento legislativo, aunque pueda entenderse inadecuado, lo cual, a estos efectos, resulta irrelevante.

\section{II.4. El examen del Real Decreto-Ley 5/1996, 7 de junio, de medidas liberalizadoras en materia de suelo}

El objeto de este Decreto-Ley entra dentro de lo que se ha venido en denominar necesidades relativas, es decir situaciones concretas relacionadas con objetivos gubernamentales, como son en este caso el abaratamiento del suelo, el incremento de su oferta y así el consiguiente incremento de la oferta de vivienda, con la correlativa bajada de precios. 
Sin embargo, el tratamiento de esta clase de necesidades es el denominador común de la acción legislativa ordinaria que, a través del impulso político, convierte los postulados programáticos en fines del ordenamiento jurídico y en ese sentido en objetivos de las Administraciones públicas para transformar la realidad.

Por ello, la Constitución, como se ha venido señalando, exige una especial cualificación de esas necesidades, a fin de que la concurrencia del Decreto-Ley sea posible y legítima. Si esa cualificación no existe, es decir si no se da el presupuesto habilitante requerido, tendremos que situar esas necesidades en el ámbito de lo ordinario, es decir en el ámbito atendible por los procedimientos ordinarios que la Constitución establece al efecto. El supuesto al que se está haciendo referencia no cumple con los requisitos constitucionalmente exigidos y por ello debe reputarse su tratamiento a través de Decreto-Ley como contrario a la Constitución.

En lo que se refiere al carácter extraordinario de la necesidad, para su reconocimiento debe existir al menos, una cierta dificultad en la previsión de las circunstancias que aconsejan la promulgación del DecretoLey. El ordenamiento jurídico urbanístico acredita fehacientemente desde sus postulados, que tal imprevisibilidad no existe, sencillamente porque durante al menos dos décadas se está ocupando de la regulación del precio del suelo, del suelo urbanizado disponible y de su repercusión en el mercado de la vivienda. En este sentido, no sólo hay que considerar el ordenamiento estatal, sino también la extraordinaria dedicación, al menos legislativa, de las Comunidades Autónomas al tratamiento de este problema $^{13}$.

Por tanto, no sólo no estamos ante una clase de problemas sorpresivamente manifestados y cuya falta de previsión sobre ellos nos empuja a dar una respuesta normativa adecuada para su solución, sino que se trata de un problema largamente padecido, largamente tratado, y actualmente regulado con una ordenación recientemente aprobada.

Además de estos antecedentes, verdaderamente relevantes, se puede añadir como prueba de falta de imprevisibilidad, la presentación por parte del propio Grupo Parlamentario Popular de una Proposición de Ley de modificación del Real Decreto Legislativo 1/1992, de 26 de junio, por el que se aprobó el Texto Refundido de la Ley sobre el Régimen del Suelo y Ordenación Urbana ${ }^{14}$, que por cierto, como desta-

13 La mención de la legislación existente en materia de suelo y vivienda resultaría abrumadora.

14 Boletín Oficial de las Cortes Generales, de 21 de octubre de 1995, núm. 155-1. 
ca JIMENEZ DE CISNEROS CID no incluía ninguna de las medidas contenidas en el Decreto-Ley ${ }^{15}$.

No quiere decirse que siempre que exista una ordenación normativa de una situación potencialmente regulable a través de Decreto-Ley, la existencia de aquélla sea un obstáculo para el citado tratamiento, pero desde luego la utilización del Decreto-Ley de acuerdo a las exigencias de la Constitución, implica la aparición de una situación nueva, cuya satisfacción no es producida a través de la regulación preexistente y sus notas de imprevisibilidad, gravedad, importancia y urgencia avalan la promulgación del Decreto-Ley. Como es obvio, con el caso que nos ocupa, no se dan estas circunstancias.

En lo que se refiere a la pretendida urgencia, es preciso también expresar algunas consideraciones. El urbanismo, tanto por su propia naturaleza, como por los caracteres del ordenamiento que lo regula, destila una total incompatibilidad con la urgencia. Los procesos de maduración que se producen en el urbanismo, desde que se diseñan y planifican originariamente, hasta que se desarrollan y llevan a la realidad de los hechos, condicionan y caracterizan la naturaleza de tal materia. La pretensión de encajar el concepto de urgencia como un elemento consustancial del entramado ordinamental urbanístico, es desconocer su propia naturaleza. Dicho de otro modo, la normal utilización de los procedimientos previstos en el ordenamiento urbanístico, implican el cumplimiento de fases y trámites, cuya consecuencia más inmediata es el consumo de tiempo en una cantidad que es en todo punto incompatible con la urgencia ${ }^{16}$. Incluso en supuestos en que concurren razones de «urgencia o excepcional interés público» (artículo 244.2 Real Decreto Legislativo 1/1992, de 26 de junio), y debido a ellas se permite la separación de las vinculaciones del planeamiento, es preceptiva la tramitación de la modificación o revisión del planeamiento, conforme a las determinaciones de la legislación urbanística. Por lo cual, la única urgencia entendible, sería aquélla que referida a una concreta actuación, tratase de evitar la aplicación del ordenamiento urbanístico, precisamente por la urgencia concurrente en el supuesto de hecho.

Sin embargo, el Decreto-Ley 5/1996, de 7 de junio, innova el ordenamiento jurídico, modificando el existente, basándose en una pretendida

15 Jiménez DE Cisneros CID, F.J.: «Los efectos de la "liberalización del suelo" sobre el Texto Refundido de la Ley del Suelo de 1992», Revista de Derecho Urbanístico y Medio Ambiente, julio-agosto-septiembre, 1996, p. 15.

${ }^{16}$ No se pretende en absoluto, una apología del modelo existente, sino más bien poner de manifiesto la condición natural de tal ordenamiento para entender en sus justos términos las relaciones entre éste y la urgencia. 
urgencia que nunca llegará a satisfacerse por la propia naturaleza de la materia. El proceso temporal en que quedan inmersas sus medidas, -reducción del aprovechamiento lucrativo susceptible de apropiación por la Administración del 15 al 10\%, identificación jurídica del suelo urbanizable programado y no programado, incluso la agilización de la tramitación y aprobación del planeamiento-, supone la relativización, incluso la neutralización, de la pretendida urgencia con la que se legisla en la materia.

Es difícil, si no imposible, pretender legítimamente la utilización de un procedimiento legislativo excepcional como es el previsto en el artículo 86.1 de la Constitución, basado, entre otras cuestiones, en una necesidad urgente, cuando la aplicación de su contenido no va a responder con tal carácter a las necesidades planteadas por el Gobierno como habilitantes del Decreto-Ley ${ }^{17}$.

Todas estas consideraciones tienen su correlativa expresión en la Exposición de Motivos del mencionado Decreto-Ley que, sin ser una excepción en lo que se refiere a la falta de suficiente motivación de los Decretos-Leyes, contiene una más que insuficiente mención a las necesidades habilitantes ${ }^{18}$ y una inadecuada relación de las medidas adoptadas con el sentido último de la situación definida, cuestión ésta sobre la que incidiremos más adelante.

El Tribunal Constitucional desde la primera de sus sentencias, ha dejado clara su exigencia de que la definición de la situación habilitante sea «explícita y razonada». De este modo el Alto Tribunal señala lo siguiente:

«El T.C. podrá, en supuestos de uso abusivo o arbitrario, rechazar la definición que los órganos políticos hagan de una situación determinada como caso de extraordinaria y urgente necesidad, de tal naturaleza que no pueda ser atendida por la vía del procedimiento legislativo de urgencia. Es claro que el ejercicio de esta potestad de control del Tribunal implica que dicha definición sea explícita y razonada y que exista una conexión de sentido entre la situación definida y las medidas que en el

17 No me refiero, como se habrá podido apreciar al sentido en que EsPósito distinguía entre norma y contenido de la norma. Vid. Espósıto, C.: Enciclopedia del Diritto, «Voz Decreto Legge», Guiffrè Editore, 1962, p. 844.

18 La Exposición de Motivos señala como justificación del Decreto-Ley lo siguiente:

«Dada la situación del mercado de suelo y la vivienda, se hace necesaria la aprobación de unas primeras medidas que ayudarán a incrementar la oferta de suelo con la finalidad de abaratar el suelo disponible. Las modificaciones propuestas de la legislación urbanística están también orientadas a simplificar los procedimientos y a acortar los plazos vigentes. Se conseguirá así, avanzar en el logro del objetivo público de garantizar con mayor facilidad el acceso a la vivienda y a reducir la enorme discrecionalidad ahora existente». 
Decreto-Ley se adoptan». (STC 29/1982, de 31 de mayo, FJ 3. Reproducido en la STC 111/83, de 2 de diciembre, FJ 5).

En su sentencia 29/1986, de 20 de febrero, valora la justificación realizada por el Gobierno, declarando:

«En el presente caso, el Gobierno justificó la adopción del Real Decreto-Ley 8/1983 (en su Exposición de Motivos), en la subsistencia de los problemas de la reconversión industrial así como en la inexistencia de una normativa adecuada para afrontarlos, una vez extinguida la vigencia de la Ley 21/1982, de 9 de Junio...» (FJ 2).

En cualquier caso, parece lógico pensar que la existencia o inexistencia de motivación, no puede constituir el elemento fundamental de decisión acerca de la constitucionalidad o no del respectivo Decreto-Ley, pero sí debe tenerse como un indicio más a ser valorado globalmente con el resto de circunstancias que concurran en el supuesto. Es posible encontrar legítimas habilitaciones para el uso del Decreto-Ley acompañadas de paupérrimas motivaciones, y al revés, extensas y artificiosas argumentaciones acerca de la justificación para dictar un Decreto-Ley que no dispone de presupuesto habilitante.

Ciertamente en este sentido se ha manifestado el Tribunal Constitucional, cuando en su sentencia 60/1986, de 20 de mayo, expresa lo siguiente:

«Con independencia de que tal motivación resulte o no convincente, lo que nos toca indagar ahora es si concurre o no realmente el presupuesto de hecho habilitante del Decreto-Ley impugnado, es decir, el caso de extraordinaria y urgente necesidad» (FJ 3).

Por tanto, cabe decir que la motivación de la justificación existente, constituirá un elemento más de juicio o referencia para el Alto Tribunal, en el contexto de una valoración conjunta.

Por otra parte, ¿qué carácter tiene la relación existente entre las medidas adoptadas y el sentido último de la situación definida como presupuesto habilitante?

El Tribunal Constitucional se ha autolimitado en la función de fiscalizar esa relación de adecuación entre situación habilitante y medidas adoptadas. En este sentido se ha decantado, cuando ha establecido que:

«El Tribunal no podría, sin traspasar las fronteras de su función y a la vez de su responsabilidad, inmiscuirse en la decisión de gobierno, pues si así se hiciera quedarían alterados los supuestos del orden constitucional democrático» (STC 111/1983, de 2 de diciembre, FJ 5).

Sin embargo en la delimitación de las fronteras de su función, se ha pronunciado con un carácter confuso que se ha interpretado y traducido 
como una ampliación de los márgenes de discrecionalidad a disposición del Gobierno.

Realmente, cuando el Tribunal Constitucional (Sentencia 29/1982, de 31 de mayo) expresa respecto al contenido dispositivo del Real DecretoLey, que el Gobierno no está autorizado a incluir en él «cualquier género de disposiciones: ni aquéllas que, por su contenido y de manera evidente, no guarden relación alguna, directa ni indirecta, con la situación que se trata de afrontar...» (FJ 3) está utilizando una fórmula más amplia y omnicomprensiva de la que posteriormente hace uso en el Fundamento Jurídico 5 de la misma sentencia, cuando expresa que «no es competencia del T.C. el pronunciarse sobre la mayor o menor oportunidad técnica de las medidas que en el mismo se establecen (...), pues ello se enmarca en la actividad propia del debate parlamentario, y la defensa en el mismo de los distintos criterios políticos que al respecto se formulen...».

Son formulaciones ciertamente distintas. Será verdaderamente difícil que el contenido de un Decreto-Ley no guarde, y además de forma evidente, ninguna relación directa ni indirecta con el presupuesto habilitante. Aunque sólo fuera porque presupuesto habilitante y medidas perteneciesen a una misma materia o sector de actividad administrativa, ya tendríamos cosida una relación habilitante y legitimadora de la normación mediante Decreto-Ley.

Parece indudable que una formulación de este tenor excede con mucho a la denominada, exigida y repetida «conexión de sentido» ${ }^{19}$ necesaria para que la relación entre la situación definida y las disposiciones adoptadas sea adecuada. Expresado de otra manera, sin necesidad de pronunciarse sobre la mayor o menor oportunidad técnica de las medidas que en él se establezcan, es posible realizar un control acerca de si existe o no una conexión de sentido entre la situación definida y las disposiciones adoptadas.

En el supuesto que nos ocupa, tal vez debiera señalarse previamente que no estamos ante un Decreto-Ley, sino ante dos Decretos-Leyes, bajo la envoltura de uno solo, dado que existen situaciones que ninguna relación poseen entre sí y que a su vez disponen de preceptos separados pretendidamente referibles a cada una de ellas.

En lo referente a la materia de suelo la Exposición de Motivos como ya se ha señalado, identifica como objetivo o situación habilitante «abaratar el suelo disponible», que según se añade en la misma Exposición se pretende conseguir mediante el incremento de la oferta de suelo.

19 SSTC 29/82, de 31 de mayo, FJ 3; 111/83, de 2 de diciembre, FJ 5. 
Una razonable conexión de sentido entre el objetivo perseguido, como es el abaratamiento del suelo disponible, y las medidas adoptadas exigiría que éstas actuasen en la estructura de costes o en la estructura del mercado, de tal manera que, bien porque se rebajen aquéllos o porque se procure la incorporación masiva o significativa de suelos al mercado, se llegue al descenso deseado de los precios. Cualquier otra medida no parece que pueda reputarse como incluida en esa manifestada por el Tribunal Constitucional conexión de sentido.

Conforme a tal criterio no parece que los artículos 1,3 y 4 puedan entenderse comprendidos en esa conexión de sentido ${ }^{20}$.

Tal consideración no debe ser entendida en ningún caso, como contraria a la postulada interdicción de realizar valoraciones en torno a la mayor o menor oportunidad técnica de las medidas, para alcanzar el objetivo previsto como es el abaratamiento del suelo. El análisis suficiente y necesario para determinar si existe esa conexión de sentido exigida, requiere un esfuerzo de contraste que, sin entrar en una valoración acerca de su idoneidad técnica, permita concluir sobre la relación existente ${ }^{21}$.

Una valoración sobre la oportunidad técnica de las medidas implicaría el rechazo de todo el Decreto-Ley, por cuanto es razonable pensar que tales normas, por sí mismas, no van a lograr el objetivo que les mueve y justifica.

En esta línea de razonamiento, parece evidente que la norma que modifica el «aprovechamiento y cesión de suelo a los Ayuntamientos» incide en el cuadro de costes del propietario de suelo, por ello podría ser reputable, sin perjuicio de lo ya manifestado en torno a la extraordinaria y urgente necesidad, como conectada con el sentido de la situación defini$d a^{22}$, sin embargo, técnicamente es rechazable, porque como el tiempo se encargará de corroborar, es claramente inidónea para lograr, por sí sola, o

20 Véanse en Addenda.

${ }^{21}$ De cualquier forma, hay que tener presente que cuando falte la conexión de sentido, no será posible encontrar tampoco idoneidad técnica en las medidas que se dicten para el tratamiento de las necesidades a que respondan. La conexión de sentido debe entenderse como un estadio inicial al acierto técnico de las medidas, de tal modo que es un requisito previo ineludible.

De este modo, es posible encontrar supuestos en que, dándose esa conexión de sentido, no se produzca la pertinente cualidad técnica que sea precisa para la adecuada satisfacción de las necesidades manifestadas, cuestión en la que no cabe la intervención del Tribunal Constitucional, como ha quedado expuesto.

22 Aunque suponga eliminar lo que FERnÁndez RodRÍGUEZ, T.R., en «Informe sobre la Ley 8/1990, de 25 de julio, y sobre el Anteproyecto de Texto Refundido de la legislación del suelo», Revista de Derecho Urbanístico, núm. 129, p. 22, identifica como el único elemento de la Ley 8/1990 «que todos sin excepción han asumido con entusiasmo: la exigencia de cesión del 15 por 100 del aprovechamiento». 
acompañada tal como se regula en el Decreto-Ley, el incremento de la incorporación de suelos al mercado, en este caso por una disminución de costes del propietario, y consiguientemente abaratar sus precios.

Este razonamiento es de aplicación también al artículo 1. Si se pone en relación este artículo con la Disposición Transitoria ${ }^{23}$, se puede apreciar que no se produce ninguna incidencia en el mercado de suelo y más concretamente en el lado de la oferta. Nuevamente debe apuntarse que no se trata de una valoración técnica, acerca de si la incidencia ocasionada es adecuada, idónea u oportuna para la consecución de los objetivos planteados, sino por el contrario consiste en la constatación de que no se produce ningún efecto en relación con el objetivo pretendido, lo cual es consecuencia de la falta de conexión de sentido ${ }^{24}$.

Las siguientes razones que se expresan, avalan ese pronunciamiento:

Primera. El Decreto-Ley no contiene ninguna disposición respecto al suelo que sea necesario y, consecuentemente, deba clasificarse como urbanizable, sino que se limita a identificar el suelo urbanizable programado con el suelo urbanizable no programado y remite al planeamiento general como la vía pertinente para la declaración de los suelos que deben ser urbanizados.

Segunda. El mantenimiento del valor normativo de los planes vigentes de acuerdo con el ordenamiento anterior a la reforma operada por el Decreto-Ley, y su extensión a los procedimientos de elaboración, modificación o revisión ya iniciados, confirma la oferta que en éstos se haya realizado, sin ninguna incidencia del Decreto-Ley al respecto.

Por tanto, puede concluirse que el Decreto-Ley produce, como derecho supletorio, para los Planes Generales futuros la identificación de dos clases de suelo, que, con anterioridad a su promulgación, tenían regímenes jurídicos diferentes, pero nada determina respecto a la cantidad de suelo urbanizable que tales Planes deben clasificar como urbanizables. Por lo cual, regula una cuestión que no tiene conexión de sentido con el objetivo que dice pretender el Decreto-Ley.

Si el Decreto hubiese impuesto algún estándar cuantitativo de clasificación de suelo urbanizable, habría logrado esa conexión de sentido que le falta, por su incidencia en la cantidad de suelo clasificado. Ello no impediría su rechazo desde una perspectiva puramente técnica, perspectiva que, como se ha venido señalando, no estaría disponible para el Tribunal

23 Véase en Addenda.

24 Obviamente relación indirecta sí existe, en la medida en que estamos tratando de problemas incluidos en un ámbito común, como es el urbanismo, lo cual no debe considerarse, como ya se ha señalado, equivalente a una relación suficiente de conexión. 
Constitucional, pues se trataría de la asunción de una «responsabilidad que no corresponde a su función, y entrañaría una injerencia en una decisión política que sólo al Gobierno - con el control parlamentariocorresponde» (STC 111/1983, de 2 de diciembre, FJ 7).

Sería técnicamente rechazable porque el problema actual no se identifica con la mayor o menor oferta de suelo clasificado, es decir con la clasificación del suelo a través de los instrumentos de planeamiento, sino con la oferta de suelo debidamente calificado y urbanizado, geográficamente distribuido de acuerdo con la demanda, es decir se identifica con el desarrollo y ejecución del planeamiento ${ }^{25}$.

Comentarios similares han de hacerse respecto a los artículo 3 y 4 . En estos casos, la falta de adecuación del presupuesto habilitante con las medidas dictadas, se aprecia desde la propia redacción de la Exposición de Motivos efectuada por el Gobierno.

Recordemos que es «la situación del mercado de suelo y la vivienda» la que hace necesaria «la aprobación de unas primeras medidas que ayudarán a incrementar la oferta de suelo con la finalidad de abaratar el suelo disponible». Esta parca declaración pretende justificar la promulgación de su parte dispositiva, pero no de toda, porque desde la propia Exposición de Motivos se añaden párrafos que intentan abarcar justificadoramente al resto de preceptos dictados.

No se dispensa ninguna cobertura específica al artículo 2, porque se entiende que la mera alusión al abaratamiento del suelo disponible, está implicando al contenido del artículo 2. Sin embargo, eso no ocurre con el resto de preceptos (1, 3 y 4), por ello precisamente se añade que las modificaciones propuestas de la legislación urbanística «están también orientadas a simplificar los procedimientos y a acortar los plazos vigentes». Lo cual no debe considerarse como un presupuesto habilitante, sino como la reproducción en la Exposición de Motivos del contenido dispuesto en los mencionados preceptos. Con dicha técnica cualquier contenido normativo disfrutaría del reconocimiento de la conexión de sentido, pues se limitaría a ser fiel reproducción del anuncio realizado en la motivación. Parece evidente que la motivación no es eso, sino la identificación de los móviles, de las necesidades que provocan y aconsejan tal normación.

La relación de adecuación, por tanto, entre el abaratamiento del suelo disponible y, en su caso, el incremento de la oferta de suelo, con la re-

25 Vid. LóPez ToledAno, M A.: «Reflexiones acerca de la supresión de la distinción entre suelo urbanizable programado y suelo urbanizable no programado establecida en el Real Decreto-Ley 5/1996, de 7 de junio, de Medidas liberalizadoras en materia de suelo y colegios profesionales», RDUMA, julio-agosto-septiembre, 1996, pp. 70 y ss. 
ducción de los plazos de tramitación del planeamiento urbanístico y los órganos competentes para su aprobación es inexistente.

\section{II.5. Los efectos de la nulidad del cuestionado Decreto-Ley}

Del artículo 86 de la Constitución puede deducirse que aprobado un Decreto-Ley por el Gobierno, y debidamente publicado en el Boletín Oficial del Estado, surte efectos en el ordenamiento jurídico como una norma jurídica provisional, dotada de valor y fuerza de Ley.

La doble vía que, a efectos de fiscalización del Decreto-Ley, ha establecido el mencionado artículo 86, en sus apartados segundo y tercero, se ha decantado en la práctica parlamentaria, como es sabido, de manera sucesiva, en vez de alternativa, de tal manera que es preciso el previo pronunciamiento favorable, para su tramitación como proyecto de Ley por el procedimiento de urgencia.

Por tanto, si una vez obtenido tal pronunciamiento favorable, se decide proseguir con el procedimiento legislativo indicado, el resultado de tal operación, será a todos los efectos una Ley formal, que sustituirá al Decreto-Ley en el ordenamiento jurídico.

En sentido contrario, como ya ha dejado fundamentado el Tribunal Constitucional, en los casos en que el Congreso de los Diputados se haya limitado a homologar el Decreto-Ley sin emprender el procedimiento legislativo de urgencia, se consolida su eficacia jurídica como tal Decreto-Ley. Así:

...«en aquellos supuestos en que el Congreso de los Diputados se haya limitado a ejercitar sus competencias fiscalizadoras contempladas en el apartado $2 .^{\circ}$ del artículo 86 de $\mathrm{CE}$ sin acudir a la vía del número $3 .^{\circ}$, no puede considerarse que el Decreto-Ley se haya convertido en Ley formal del Parlamento, tras el acuerdo de convalidación, sino únicamente que se ha cumplido con el requisito constitucional del que dependía la pervivencia en el tiempo, con fuerza y valor de Ley, de la disposición producto del ejercicio de la potestad normativa extraordinaria que al Gobierno le reconoce la Constitución. En otras palabras, el Decreto-Ley no se transforma en Ley, es decir, no cambia su naturaleza jurídica. Esta situación es la misma en que se encuentra el Decreto-Ley en los supuestos en que se acuda a su tramitación como proyecto de Ley en el lapso de tiempo que transcurre entre la convalidación de totalidad como Decreto-Ley (...) y la publicación en el Boletín Oficial del Estado de la Ley resultante de la referida tramitación como proyecto de Ley por procedimiento de urgencia (...)» (STC 29/82, de 31 de mayo, FJ 2).

La tramitación del Decreto-Ley como proyecto de Ley posibilita, como se ha dicho, su conversión en Ley formal y consiguientemente, 
como ha señalado el Tribunal Constitucional y se ha encargado de destacar SANTOLAYA MACHETTI ${ }^{26}$, la sustitución de la provisionalidad del contenido normativo del Decreto-Ley, por la vigencia indefinida o estabilidad de la Ley formal. Ahora bien, debe tenerse en cuenta que el Decreto-Ley y, en su caso, la Ley formal tienen una existencia separada ${ }^{27}$, en la que caben distintas posibilidades que abonan esta separación. Por una parte, la Ley que sustituye al Decreto-Ley no absorbe necesariamente los vicios que haya podido tener el Decreto-Ley. Es tan posible que se reproduzcan las razones de inconstitucionalidad del Decreto-Ley en la Ley que lo sustituya como lo contrario, bien porque ésta elimine dichas razones o bien porque los motivos para postular la inconstitucionalidad de aquél, no son causa de inconstitucionalidad de la Ley. Por otra parte, la Ley formal no puede sanar retroactivamente, aunque lo pretenda, los vicios que se hayan podido producir originariamente en el Decreto-Ley. Como señala SORIANO, «se trataría de un acto realizado al amparo de una norma (la ley de sustitución) que persigue un acto contrario al Ordenamiento jurídico (integrado, en tal caso, por la sentencia del Tribunal Constitucional), por lo que se crea un evidente punto fraudulento de conexión que, por tanto, no impedirá la debida aplicación de la norma (la sentencia del Tribunal Constitucional) que se hubiera tratado de eludir» 28 .

Sin embargo, aunque su discurso parte de la preexistencia de una sentencia del Tribunal Constitucional al momento de promulgación de la ley de sustitución, también deben entenderse comprendidos en la posibilidad del juicio de constitucionalidad, los supuestos en que se haya dictado la ley de sustitución con anterioridad al pronunciamiento del Tribunal Constitucional sin que en ningún caso deba limitarse su fallo por el hecho de que se trate de una norma derogada o pretendidamente sanada con carácter retroactivo.

En este sentido, el Tribunal Constitucional, en su sentencia 111/83, de 2 de diciembre, rechaza la identificación de la relación entre DecretoLey y Ley de sustitución, con cualesquiera otras producidas mediante la derogación de una ley por otra posterior. Se manifiesta del siguiente modo:

26 Santolaya Machetti, P.: El régimen constitucional de los Decretos-Leyes, op. cit., 136 y ss.

${ }^{27}$ Vid. Astarloa Huarte-MendicoA, I.: «Teoría y práctica del Decreto-Ley en el ordenamiento español», op. cit., pp. 157-158.

28 SoRIANO, J.E.: «Los Decretos-Leyes en la jurisprudencia constitucional española», op. cit., p. 466. 
«El problema aquí planteado no es idéntico al que surgiría en un supuesto recurso directo de inconstitucionalidad contra una ley que, aunque vigente en el momento de haberse interpuesto aquél, hubiera sido posteriormente derogada; ni tampoco podrían identificarse entre sí estos dos últimos supuestos, pues el primero perseguiría el control abstracto, mientras que el segundo buscaría un control concreto, y, por consiguiente, aunque tanto el recurso como la cuestión tienen por objeto el enjuiciamiento de normas, en uno y otro podrían justificarse soluciones distintas, en cuanto a la desaparición de la razón del proceso, pues mientras en el recurso directo la derogación por lo común extinguirá el objeto, en la cuestión de inconstitucionalidad la solución puede ser otra por cuanto la validez de la norma — aún derogada - puede requerir un juicio de constitucionalidad. El supuesto del artículo 86.3 y la sustitución del Real Decreto-Ley por la Ley con una eficacia retroactiva que no es el caso examinar en este momento ofrece unas particularidades que impiden extender a él las conclusiones que pudieran inferirse de lo que acabamos de decir, desde las dos vertientes del control abstracto y del control concreto» (FJ 2).

En estos supuestos, por tanto, es posible seguir adelante con la impugnación del Decreto-Ley a pesar de que haya sido sustituido.

«Que el control del Decreto-Ley en cuanto tal no está impedido por el hecho de la novación operada por la Ley, siguiendo lo que dispone el artículo 86.3, es algo fuera de duda, pues ha de considerarse constitucionalmente legítimo que en defensa de la Constitución, para velar por la recta utilización del instrumento previsto para los casos que señala el artículo 86.1, los sujetos u órganos legitimados para promover el recurso de inconstitucionalidad, concreten al Decreto-Ley, sin atraer al proceso la Ley ulterior, la impugnación. El interés constitucional que mueve a los recurrentes es así el de ajustar el uso del instrumento del Decreto-Ley hacia el cauce del artículo 86.3, y por otro, no puede quedar sin enjuiciamiento acudiendo a la idea — que nada autoriza— de gravar a los recurrentes con la carga de impugnar la Ley, como presupuesto para enjuiciar los vicios que el Decreto-Ley pudiera tener en cuanto tal. Pudiera acaso pensarse que una eficacia retroactiva de la Ley que diera cobijo a los efectos producidos por el Decreto-Ley puede privar de sentido a la impugnación dirigida, y ceñida por la voluntad de los parlamentarios recurrentes al Decreto-Ley, mas esto no es así, pues sin cuestionar ahora si un vicio en origen por utilización del instrumento del Decreto-Ley, contra lo que previene el artículo 86.1, puede comunicar efectos invalidatorios, es lo cierto que el velar por el recto ejercicio de la potestad de emitir Decretos-Leyes, dentro del marco constitucional, es algo que no puede eludirse por la utilización del procedimiento del artículo 86.3» (FJ 3).

No obstante, en la misma sentencia se producen algunas contradicciones en lo que se refiere al reconocimiento de cierta eficacia sanatoria de la ley de sustitución: 
...«en un procedimiento legislativo que tiene su origen en un DecretoLey se culmina con una Ley que sustituye - con los efectos retroactivos inherentes a su objeto- al Decreto-Ley. El Decreto-Ley llevaba dentro de sí — al acudirse a la vía del artículo 86.3- el límite de su vigencia. Con estas precisiones es de donde debe examinarse si la conversión del Decreto-Ley en Ley priva de contenido al proceso o, en otra hipótesis, que es la que compartimos, reduce su ámbito litigioso. La otra alternativa, cual es la vinculación al proceso incoado, esto es, a la situación legislativa que configuró la pretensión sin operarse transformación alguna, no es aceptable, pues ni el proceso congela las facultades legislativas ni la definición y alcance del litigio puede entenderse perpetuado al momento de su plateamiento, ajeno a las vicisitudes posteriores que resulten, en general, del ejercicio de potestades legislativas» (FJ 2).

Precisamente en este sentido se manifestó, entre otras cuestiones, el voto particular formulado en la mencionada sentencia:

«La relación entre ambas normas puede ser entendida de dos maneras diferentes: bien considerando que el Decreto-Ley y la Ley posterior son dos normas distintas, bien estimando que representan dos momentos de la misma norma. Estas dos concepciones llevan a consecuencias divergentes. La primera de ellas obliga a concluir que, por tratarse de dos normas distintas, la impugnación del Decreto-Ley no se extiende a la Ley, cuya constitucionalidad, en consecuencia, no podrá ser examinada por impedirlo así la naturaleza del recurso de inconstitucionalidad y más precisamente, y a contrario, el artículo 39.1 de la LOTC. También conduce ineludiblemente a la conclusión de que la Ley carece de efecto alguno sobre el Decreto-Ley anterior, al que deroga, por lo que subsisten los vicios que éste efectivamente tuviera en el momento anterior a la derogación. La segunda concepción permite entender que la Ley posterior subsana en alguna medida los vicios del Decreto-Ley, pero, lógicamente, obliga a considerar que la impugnación de éste incluye también la de aquélla, ya que la Ley no es sino una prolongación en otra forma del Decreto-Ley.

\section{(...)}

La opinión de la que disentimos oscila entre estas dos concepciones incompatibles, aceptando de cada una de ellas tan sólo una consecuencia y negando la otra. Estima, de una parte, que la impugnación del DecretoLey no arrastra necesariamente la impugnación de la Ley, pero al mismo tiempo, mediante alusiones a la "retroactividad" de esta Ley, cuyo alcance como norma determinante de la expropiación hace retroceder hasta el momento de la promulgación del Decreto-Ley, atribuye implícitamente a la Ley eficacia para sanar los vicios formales del Decreto-Ley.

Por nuestra parte entendemos que el Decreto-Ley, que se encontraba vigente en el momento de interponer el recurso de inconstitucionalidad, es una norma distinta de la Ley posterior, pues de otro modo desaparecerían las limitaciones que el artículo 86.1 de la Constitución impone al Decreto-Ley. Por ello, a nuestro parecer, si bien en ningún caso podría ser 
enjuiciada la Ley posterior no recurrida por impedirlo el artículo 39.1 de la LOTC, la sentencia, en cambio, debió extenderse al enjuiciamiento de la totalidad del Decreto-Ley, con objeto de determinar su conformidad o disconformidad con la Constitución, cuya supremacía corresponde preservar a este Tribunal en caso de recurso, de acuerdo con el artículo 27.1 de su Ley Orgánica» (FJ 1).

El Decreto-Ley que nos ocupa fue sometido a debate y votación de totalidad por el Congreso de los Diputados, en su sesión del día 20 de junio de 1996 , en la que se acordó su convalidación ${ }^{29}$, así como su tramitación como proyecto de ley por el procedimiento de urgencia.

El sentido de las enmiendas presentadas, manifiestan, por diferentes razones, un rechazo a la regulación contenida en el Decreto-Ley y hacen presagiar que el contenido último de la Ley, en función de los apoyos con que cuente, tenderá exclusivamente a convertir en Ley las disposiciones del Decreto-Ley, sin innovaciones de mayor relevancia.

\section{II.6. Los límites materiales}

El Tribunal Constitucional, en su sentencia 29/1982, de 31 de mayo, reprodujo los requisitos exigidos en el artículo 86 de la Constitución para dictar Decretos-Leyes, y a tal efecto señaló lo siguiente:

«Tales requisitos, (...) están recogidos en la C.E., configurando tres bloques definidos: (...); b) la limitación en cuanto a la materia sobre la que puede incidir un Decreto-Ley, lo que supone el que en ningún caso pueda afectar al ordenamiento de las instituciones básicas del Estado, a los derechos, deberes y libertades de los ciudadanos regulados en el título I de la C.E...» (FJ 1).

Como acertó a entender alguna doctrina ${ }^{30}$, el Tribunal Constitucional no pretendía en ese momento resolver si la referencia a los derechos y libertades del Título I, lo era a la totalidad del Título o a la Sección Primera de su Capítulo Segundo, sino simplemente esquematizar el contenido del citado artículo.

Poco después la sentencia 111/1983, de 2 de diciembre, despejaba algunas incógnitas, aunque sin resolver totalmente el problema. En este sentido planteó lo siguiente:

29 Publicado en el Boletín Oficial de las Cortes Generales, de 24 de junio de 1996, núm. 29.

30 Vid. SoRIANO, J.E.: «Los Decretos-Leyes en la jurisprudencia constitucional española», op. cit., pp. 460-461. 
«Una interpretación del artículo 86.1 que lleve en este punto a una restricción de lo que dice su letra, para reducir el ámbito de la limitación de modo que se hagan coincidir las menciones referentes a los derechos y libertades con la materia reservada a la Ley Orgánica, tal como define el artículo 81.1, con trascendencia también para la legislación delegada, aunque implica un esfuerzo hermenéutico que no deja de contar con algunos apoyos, no es conciliable con una interpretación vinculada a unos cánones atentos no sólo al propio sentido literal del precepto, sino, además, a un análisis comparativo con los otros artículos (los arts. 81 y 82) y a lo expuesto en nuestra sentencia de 4 de febrero de 1983 (...) en la que, a propósito del artículo 31 de la CE, situado en la misma sección que el artículo 33 ahora invocado, el criterio adoptado no fue el de la coextensión de los artículos 81.1 y 86.1 de la CE» (FJ 8).

El Tribunal Constitucional, lo mismo que rechaza una restricción del ámbito de limitación material del Decreto-Ley, descarta una interpretación que suponga la total neutralización del Decreto-Ley. Así establece en el mismo Fundamento Jurídico lo siguiente:

...«la tesis partidaria de una expansión de la limitación contenida en el 86.1 de la CE se sustenta en una idea tan restrictiva de la limitación contenida del Decreto-Ley que lleva en su seno el vaciamiento de la figura y la hace inservible para regular con mayor o menor incidencia cualquier aspecto concerniente a las materias incluidas en el Título I de la Constitución sin más base interpretativa que el otorgamiento al verbo "afectar" de un contenido literal amplísimo; como con tan exigua base se conduce a la inutilidad absoluta del Decreto-Ley, pues es difícil imaginar alguno cuyo contenido no afectase a algún derecho comprendido en el título I, es claro que tal interpretación, fácilmente reducible ad absurdum, tampoco puede ser aceptada, ni la aceptó el Tribunal en su sentencia de 4 de febrero de 1983...» (FJ 8).

El Tribunal adopta una posición intermedia que no soluciona, como antes se decía, el problema de interpretación existente. Descarta las posiciones extremas, eso sí, pero deja sin establecer los criterios fijos que sirvan para determinar el ámbito de los derechos, deberes y libertades de los ciudadanos prohibido al Decreto-Ley. O al menos los que fija son orientaciones que siempre habrá que entender adaptables a cada supuesto que fiscalice el Alto Tribunal. En este sentido, continúa señalando lo siguiente:

...«la cláusula restrictiva del art. 86.1 de la C.E. ("no podrán afectar"...) debe ser entendida de modo tal que ni reduzca a la nada el Decreto-Ley, (...), ni permita que por Decreto-Ley se regule el régimen general de los derechos, deberes y libertades del Título I, ni dé pie para que por Decreto-Ley se vaya en contra del contenido o elementos esenciales de 
alguno de tales derechos. Esta vía interpretativa exige también que se tenga muy en cuenta la configuración constitucional del derecho afectado en cada caso e incluso su colocación en el texto constitucional dentro de las diversas secciones y capítulos de su Título I, dotados de mayor o menor rigor protector a tenor del art. 53 de la C.E. En el caso que nos ocupa, el derecho de propiedad, incluida en la Sección Segunda del Capítulo 2. ${ }^{\circ}$ del Título I, aparece regulado en el art. 33, donde se contiene una doble garantía de tal derecho, ya que se reconoce desde la vertiente institucional y desde la vertiente individual, esto es, como un derecho subjetivo, debilitado;...».

Por tanto, para finalizar, de acuerdo con esta doctrina jurisprudencial, que ha sido reiterada, entre otras, en la sentencia 3/1988, de 21 de enero, FJ 7 y 8, es preciso cotejar tres parámetros:

1. ${ }^{\circ}$ La configuración constitucional del derecho afectado, a fin de determinar el grado de protección que la Constitución dispensa.

2. ${ }^{\circ} \mathrm{Si}$ se produce mediante Decreto-Ley una regulación general del régimen general de alguno de los derechos, deberes y libertades contenidos en el Título I.

3. ${ }^{\circ} \mathrm{Si}$ se produce una restricción de alguno de los elementos fundamentales o significativos que componen de esos derechos.

En el caso que nos ocupa, no se produce la incidencia de ninguno de los requisitos o criterios fijados por el Tribunal Constitucional, por lo que cabe simplemente concluir que el analizado Decreto-Ley no desborda los límites materiales planteados por el artículo 86.1 de la Constitución. 


\section{Addenda}

REAL DECRETO-LEY 5/1996, 7 junio. Medidas liberalizadoras en materia de suelo y de Colegios Profesionales (BOE 8 junio 1996; C.E., BOE 18 junio 1996).

\section{EXPOSICION DE MOTIVOS}

Dada la situación del mercado de suelo y la vivienda, se hace necesaria la aprobación de unas primeras medidas que ayudarán a incrementar la oferta de suelo con la finalidad de abaratar el suelo disponible. Las modificaciones propuestas de la legislación urbanística están también orientadas a simplificar los procedimientos y a acortar los plazos vigentes. Se conseguirá así, avanzar en el logro del objetivo público de garantizar con mayor facilidad el acceso a la vivienda y a reducir la enorme discrecionalidad ahora existente.

Así, de acuerdo con el artículo 1, los Planes Generales de Ordenación Urbanística cuya tramitación comience tras la aprobación de este Real Decreto-Ley contendrán una sola clasificación de suelo urbanizable. En el artículo 2, se modifica la cesión de suelo a los ayuntamientos situándola en el 10 por 100. El artículo 3 reduce los plazos de aprobación del planeamiento por los ayuntamientos. El artículo 4, modifica la ley de Bases de Régimen Local facilitando las aprobaciones de los instrumentos de planeamiento y de gestión urbanística. Finalmente, la disposición transitoria establece un procedimiento más sencillo para promover el suelo que el planeamiento vigente o en tramitación clasifique como urbanizable no programado.

En lo que respecta a Colegios Profesionales, se modifican determinados aspectos de la regulación de la actividad de los profesionales que limitan la competencia, introduciendo rigideces difícilmente justificables en una economía desarrollada. En primer lugar, con carácter general, se reconoce la sujeción del ejercicio de las profesiones colegiadas al régimen de libre competencia. En segundo lugar, se establece que el indispensable requisito de colegiación deberá únicamente realizarse en el colegio territorial correspondiente al domicilio del profesional. Finalmente, se elimina la potestad de los Colegios Profesionales para fijar honorarios mínimos, si bien podrán establecer baremos de honorarios orientativos. El Gobierno de la Nación ha sido consciente, desde su toma de posesión, de la necesidad de implementar medidas en la dirección referida con carácter urgente, a fin de aprovechar los efectos sobre la capacidad de crecimiento de la economía española y eliminar los innumerables perjuicios generados por ésta sobre regulación de la economía. Todo lo cual justifica plenamente el empleo de la técnica normativa del Real Decreto-Ley autorizada por el artículo 86 de la Constitución.

En su virtud, a propuesta del Vicepresidente Segundo del Gobierno y Ministro de Economía y Hacienda y de los Ministros de Fomento y Administraciones Públicas previa deliberación del Consejo de Ministros en su reunión del día 7 de junio, en uso de la autorización concedida en el artículo 86 de la Constitución. 


\title{
DISPONGO:
}

\author{
Capítulo primero
}

Suelo

Artículo 1. Supresión de la distinción entre suelo urbanizable programado y suelo urbanizable no programado. Uno. Queda suprimida la distinción entre suelo urbanizable programado y no programado establecida en el Real Decreto-Legislativo 1/1992, de 26 de junio, refundiéndose ambas clases de suelo, denominándose suelo urbanizable.

Dos. Constituirán el suelo urbanizable los terrenos a los que el planeamiento general declare adecuados para ser urbanizados.

Tres. Para el desarrollo urbanístico del suelo urbanizable serán de aplicación las disposiciones contenidas en el Real Decreto-Legislativo 1/1992 para suelo urbanizable programado.

Art. 2. Aprovechamiento y cesión de suelo a los Ayuntamientos. Uno. En suelo urbano el aprovechamiento urbanístico del titular de un terreno no incluido en una unidad de ejecución, será el que resulte de aplicar el aprovechamiento tipo del área de reparto en el que se encuentre o, en su defecto, de la aplicación directa de las ordenanzas o normas urbanísticas de la parcela.

Dos. El aprovechamiento urbanístico que corresponde al titular de un terreno en suelo urbano incluido en una unidad de ejecución y en el suelo urbanizable, será el que resulte de aplicar a su terreno el 90 por 100 del aprovechamiento tipo se tendrá en cuenta el aprovechamiento medio de la unidad de ejecución o del correspondiente sector en que se halle.

Tres. Las obras de rehabilitación y la sustitución de la edificación sin aumento del volumen construido, aun en los casos de hallarse en el ámbito de una unidad de ejecución, no dará lugar a cesiones de aprovechamiento tipo a la corporación.

Art. 3. Reducción de plazos. Con carácter supletorio, y siempre que no se disponga de manera diferente en la legislación urbanística, los plazos de tramitación serán los siguientes:

Uno. El período de información pública al que se hace referencia en los artículos 114.1 y 116 .a) no superará los dos meses.

Dos. En el segundo párrafo del artículo 116.a) la expresión: (...) en los supuestos de planes de iniciativa particular, será de tres meses desde (...); se sustituye por (...) En los supuestos de planes de iniciativa particular, será de dos meses desde (...).

Tres. En el segundo párrafo del artículo 116.a), la expresión: (...) no podrá exceder de un año desde (...); se sustituye por: (...) no podrá exceder de seis meses desde (...).

Cuatro. En el artículo 117.2, la expresión: (...) los Ayuntamientos competentes en el plazo de tres meses (...); se sustituye por (...) los Ayuntamientos competentes en el plazo de dos meses.

Cinco. En el artículo 119.3, la expresión: (...) de detalle, será de tres meses desde (...), se sustituye por: (...) de detalle, será de dos meses desde (...).

Art. 4. Modificación de la Ley 7/1985, de 2 de abril, de Bases del Régimen Local. Uno. Se sustituye el párrafo m) del artículo 21.1 por el siguiente apartado: 
«m) las aprobaciones de los instrumentos de planeamiento de desarrollo del planeamiento general y de gestión urbanística no expresamente atribuidas al Pleno, así como la de los Proyectos de Urbanización.»

Dos. En el artículo 21.1, el párrafo m) en su anterior redacción pasa a ser el párrafo $\mathrm{n}$ ).

Tres. Se modifica el contenido del párrafo c) del artículo 22.2, queda redactado de la siguiente forma:

«c) la aprobación inicial del planeamiento general y la aprobación que ponga fin a la tramitación municipal de los Planes y demás instrumentos de ordenación y gestión previstos en la legislación urbanística.»

Cuatro. Se modifica el contenido del párrafo i) del artículo 47.3, que queda redactado de la siguiente forma:

«i) la aprobación inicial del planeamiento general y la aprobación que ponga fin a la tramitación municipal de los Planes e instrumentos de ordenación previstos en la legislación urbanística.»

\section{DISPOSICION TRANSITORIA}

Urbanismo y suelo. A los procedimientos ya iniciados antes de la entrada en vigor del presente Real Decreto-Ley no les será de aplicación lo dispuesto en los artículos 1,3 y 4 del mismo, rigiéndose por la normativa anterior.

El suelo clasificado como urbanizable no programado en el planeamiento como urbanizable no programado en el planeamiento vigente o en tramitación a la entrada en vigor del presente Real Decreto-Ley, mantendrá el régimen jurídico previsto en la normativa urbanística anterior. No obstante, podrán promoverse y ejecutarse directamente Programas de Actuación Urbanística sin necesidad de concurso, bien por iniciativa pública o por iniciativa privada mediante cualquiera de los sistemas de actuación previstos en la legislación urbanísitca.

\section{DISPOSICION DEROGATORIA}

Quedan derogadas las normas legales o disposiciones administrativas que se opongan a lo previsto en el presente Real Decreto-Ley.

\section{DISPOSICIONES FINALES}

Primera. Al amparo de los artículos 149.1.1..$^{\mathrm{a}}$ 8. $.^{\mathrm{a}}, 13 .^{\mathrm{a}}, 18 .^{\mathrm{a}}$ y $23 .^{\mathrm{a}}$ de la Constitución, se declara el carácter de legislación básica del artículo 2 de este Real Decreto-Ley.

Segunda. Al amparo de los artículos 149.1.1. ${ }^{\mathrm{a}}$ y 149.1.18. ${ }^{\mathrm{a}}$ de la Constitución tienen carácter de legislación básica los artículos 2.1, 2.4, 3.2, 3.3 y 5.ñ de la Ley 2/1974, de 13 de febrero, reguladora de los Colegios Profesionales.

Tercera. El presente Real Decreto-Ley entrará en vigor al día siguiente de su publicación en el Boletín Oficial del Estado. 


\title{
ANALISIS Y SEGUIMIENTO DE DROGODEPENDIENTES DE OPIACEOS
}

\author{
Félix Calvo Gómez \\ Catedrático de Sociología. Universidad de Deusto
}

Sumario: 1. Enfoque y marco de la investigación. 1.1. Objetivos. 1.2. Población a analizar y muestra seleccionada. 1.3. Diseño de la investigación. 2. Análisis de resultados. 2.1. El «adicto tipo». 2.2. Consumo de drogas. 1. Consumo de heroína. 2. Consumo de cocaína. 3. Consumo de otras drogas. 4. Consumo de alcohol. 5. Policonsumo. 6. Orden del consumo de drogas. 7. Edad del Inicio. 2.3. Tratamientos previos y tratamientos actuales. 1. Modalidades de tratamientos previos. 2. Atención en urgencias. 3. Tratamiento en curso en el período 30-junio-1993 al 30-junio-1994. 4. Comparación entre los grupos de metadona, naltrexona y sin tratamiento. A) Comparación primaria entre los grupos. B) La comparación entre los grupos «homogeneizados». 2.4. Hábitos de Riesgo. 1. Utilización de jeringa (aguja y émbolo) en los últimos seis meses. 2. Utilización de preservativos en las relaciones sexuales. 2.5. Ajuste social. 2.6. Estado de Salud Psicopatológico. a) Relación con los rasgos básicos de identificación. 2.7. Estado de Salud orgánico. A) Seroprevalentes al VIH. B) Diagnóstico de SIDA. C) Hepatitis.

\section{Enfoque y marco de la investigación}

La presente exposición pretende fundamentalmente aportar de manera sucinta los resultados de la investigación llevada a cabo entre los drogodependientes de opiáceos de la Comunidad de La Rioja durante 1995, motivada por el interés del Gobierno Autónomo de analizar en profundidad la realidad existente y poder de ese modo incidir en mejoras de planificación preventiva y asistencial. 


\subsection{Objetivos}

El estudio se concreta y se inicia cronológicamente a partir de un Convenio de Colaboración entre la Consejería de Salud, Consumo y Bienestar Social del Gobierno de La Rioja y el I.D.D. (Instituto Deusto de Drogodependencias) de la Universidad de Deusto firmado el 18-octubre1994 con el objetivo general de conocer las características y situación actual a la vez que evolutiva de los drogodependientes que han iniciado tratamiento en los servicios sanitarios de la Comunidad de La Rioja.

Este objetivo general queda descompuesto en siete bloques de objetivos específicos:

1. Conocer las características sociodemográficas de los usuarios que han tenido al menos un contacto con los servicios. El interés por construir el perfil del «Adicto Tipo» necesita disponer de un conjunto de variables como Fecha de Nacimiento, Sexo, Lugar de Nacimiento del usuario y de su padre, Lugar de residencia estable actual (municipio y Zona Básica de Salud), Estado Civil, Profesión, Situación laboral, escolarización, etc.

2. Averiguar el Inicio y la Evolución en el uso de drogas y de la dependencia. Se necesita la edad de inicio en el consumo de las diferentes sustancias, la cantidad y frecuencia del consumo previo y actual, la vía de administración, etc.

3. Historia de los tratamientos previos y situación toxicológica actual. Todo ello según centros, tipo de tratamiento y tiempo de retención en el programa.

4. Detectar los Hábitos de riesgo especialmente en relación con el contagio del VIH (UDVP, compartir jeringuillas, relaciones sexuales seguras, etc.).

5. Estimar el Nivel de Ajuste Social en base al número y la clase de las posibles complicaciones policiales y judiciales.

6. Analizar los resultados del GHQ28 sobre el Estado de Salud Psicopatológico.

7. Verificar el Estado de Salud Orgánico con las variables recogidas en los Servicios.

Las directrices instrumentales para la consecución de estos objetivos se conciben desde la perspectiva del «modelo de análisis explicativo». No se pretende llegar a la finura y complejidad de los modelos causales ni tampoco, por ejemplo, a los basados en la investigación en la acción. Tampoco pretenden quedarse en la mera descripción o exploración de los elementos más sobresalientes de la situacionalidad vital de los drogodependientes. El hallazgo de factores influyentes sobre diversos comporta- 
mientos y actitudes, las interrelaciones entre las áreas investigadas, la atención expresa a la variable tiempo como hecho diferenciador de los posibles grados de evolución, las comparaciones entre los diferentes grupos de drogodependientes, etc., deben constituir los cauces del intento de captación explicativa de la realidad personal de los adictos a la droga.

\subsection{Población a analizar y muestra seleccionada}

El total de los adictos a la heroína censados en la Comunidad de La Rioja según los datos de la red de servicios alcanza la cifra de $N=406$ considerando el período 30 de junio de 1993 a 30 de junio de 1994 .

A partir de ese censo existente donde están recogidas algunas pocas características se llega a establecer una Descripción Existencial con los siguientes perfiles:

\begin{tabular}{|l|r|r|}
\hline \multicolumn{1}{|c|}{ SITUACION } & Número & Porcent. \\
\hline Fallecidos & 6 & 1,5 \\
\hline En Prisión & 17 & 4,2 \\
\hline Comunidades Terapéuticas & 21 & 5,2 \\
\hline Estado Terminal & 10 & 2,5 \\
\hline Fuera de La Rioja & 36 & 8,9 \\
\hline Resto & 316 & 77,8 \\
\hline Total & 406 & 100,0 \\
\hline
\end{tabular}

En base a la experiencia de campo y el conocimiento del modus vivendi de los drogadictos se admite la existencia de un cierto grupo de ellos que no iba a poder ser localizado por diferentes motivos. El empeño y el esfuerzo ha de ponerse en disminuir el número de los componentes de este grupo.

Finalmente la cuantía del Colectivo Total Ilocalizable o de difícil accesibilidad llega a 113. Esta cifra la componen:

-6 fallecidos.

-4 en prisión y sin posibilidad de acceso a la entrevista: (celda de castigo, incomunicado, etc. (Otros 13 sí respondieron.)

-13 en Comunidades Terapéuticas siguiendo procesos de rehabilitación que no contemplan como oportuno la participación en autoanálisis personales vía encuesta-test. (8 sí respondieron.)

-36 con lugar de residencia fuera de La Rioja. 
- 10 en estado terminal.

— 44 «sin noticia» por no tener prácticamente ninguna información sobre ellos salvo la de haber acudido una o dos o como máximo tres veces a consulta en alguno de los centros y posteriormente no saber nada más de él salvo que sigue viviendo en La Rioja. dientes.

El Colectivo Total Accesible llega, por tanto, a 293 drogodepen-

El trabajo de campo se plantea con las características del «tipo de mиеstreo polifásico» por el que se llevan a cabo labores de recogida de datos en cinco fases diferentes y con la idea clara y esforzada de atender minuciosamente a todas las cuestiones o dudas presentables por los adictos en las entrevistas personales. Finalmente se llega a un total de muestra de $\mathrm{N}=222$ adictos entrevistados.

Los $N=222$ entrevistados supone un porcentaje de cobertura del $75,77 \%$ respecto al colectivo total accesible, cifra ciertamente muy superior a la alcanzada en otros estudios, sobre todo considerando el escaso tiempo en el que debió abordarse todo el proceso del trabajo de campo y las dificultades inherentes al mismo.

Las características primarias e identificativas de ese conjunto muestral demuestran su alta representatividad no sólo respecto al colectivo total accesible sino al colectivo total de los 406 drogadictos como puede apreciarse en el gráfico adjunto.

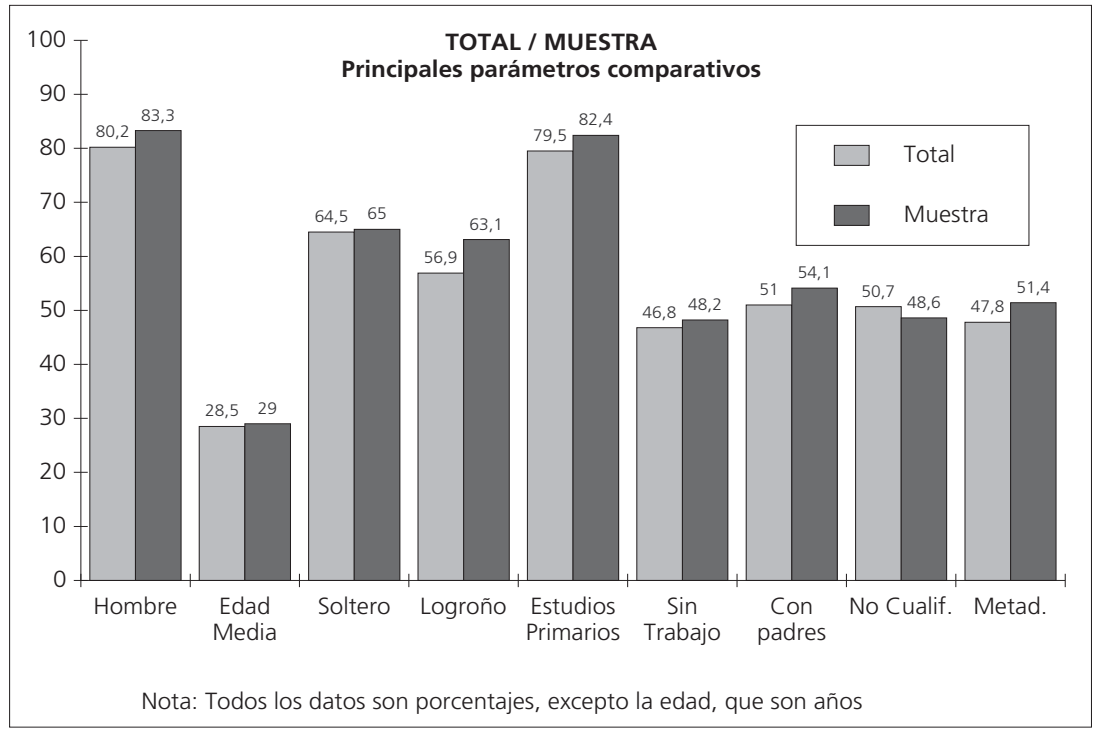


Unicamente respecto a estar en el Programa de Metadona la muestra no es representativa del conjunto total por estar ilocalizables o inaccesibles algunos de ellos aunque sí respecto al colectivo de 293 sujetos accesibles.

En general, salvo en el caso de estar en programas de tratamiento, del resto de sujetos no entrevistados, como ya se ha comprobado en otros estudios, puede afirmarse su no diferencialidad global respecto a los sí presentes en el seguimiento y análisis.

\subsection{Diseño de la investigación}

El diseño de la investigación en coherencia lógica con el «modelo explicativo» de análisis elegido conjuga dos tipos de estrategias metodológicas con enfoques diferentes pero complementarios: el correspondiente, por una parte, al «experimento ex-post-facto» y el correspondiente a los estudios «panel».

Efectivamente, ante la realidad social particular de los adictos a la heroína en la Comunidad de La Rioja se indagan a posteriori o ex-postfacto los factores determinantes de esa realidad. No es, pues, un experimento en sentido estricto al carecer entre otros detalles de grupo control y de grupo o grupos experimentales a los cuales se les mide antes, se efectúa el experimento y se vuelve a medir al final del mismo.

Por otra parte, los «panel» exigen una primera medición sobre un grupo de sujetos controlados a los cuales se les sigue midiendo posteriormente en sucesivas ocasiones. En la investigación se ha acudido a una fórmula sustitutiva: los sujetos deben responder a preguntas dirigidas al momento actual y también a momentos precedentes. Por otra parte, los resultados obtenidos en la actualidad pueden ser considerados como una primera medición sobre un grupo de sujetos adictos conocidos a los cuales se les podrá medir cuando haya transcurrido un cierto período de tiempo y obtener así resultados acerca de sus variaciones conductuales o actitudinales.

Los instrumentos de medida construidos al efecto con el bagaje de la aportación ya hecha en otros estudios han sido dos: la Encuesta-Test de Opinión y Situación Personal (Cfr. Anexo I) concebida desde la perspectiva del conocimiento de ciertas variables o noticias sólo por parte del propio sujeto y, en consecuencia, deberá de ser éste mediante el «autoinforme» el propio relator de su estado y situación. Cuando los datos pueden ser obtenidos mediante Archivos e Informes existentes se acude a esta fuente de datos como así ocurre con el Cuestionario sobre el Estado de Salud Orgánico, segundo instrumento de medición creado también expresamente para este estudio. 


\section{Análisis de resultados}

\subsection{El «adicto tipo»}

El constructo adicto «tipo» presenta los siguientes parámetros caracterizadores:

\begin{tabular}{|l|c|c|}
\hline \multicolumn{1}{|c|}{ Parámetros } & $N$ & $\%$ \\
\hline Hombre & 185 & $83,3 \%$ \\
\hline Edad Media & \multicolumn{2}{|c|}{29 años } \\
\hline Soltero & 143 & $65,0 \%$ \\
\hline Vive en Logroño & 140 & $63,1 \%$ \\
\hline A lo más estudios primarios & 183 & $82,4 \%$ \\
\hline Con trabajo & 113 & $51,4 \%$ \\
\hline Vive con sus padres & 120 & $54,1 \%$ \\
\hline Trabajador No cualificado & 98 & $48,6 \%$ \\
\hline Programa de metadona & 114 & $51,4 \%$ \\
\hline
\end{tabular}

La tabla anterior puede ser completada con diversos detalles más amplios:

- Lugar de nacimiento y lugar de residencia:

- El $62,2 \%$ ha nacido en La Rioja. Un $13,4 \%$ ha nacido en el País Vasco.

- El 63,1\% reside en Logroño.

- El $89,6 \%$ tiene residencia fija y un $10,4 \%$ admite no tener residencia fija o estable.

-Edad:

- El 12,6\% de los entrevistados tiene 22 años o menos.

- Tan sólo un 13,5\% tiene más de 35 años.

- El grupo mayoritario se sitúa entre los 27 y 30 años: 28,4\%.

- Tan sólo un 13,5 tiene más de 35 años. (Cfr. Gráfico.)

-Nivel de estudios:

- Es destacable el bajo nivel de estudios de los entrevistados pues llega al 82,5\% los que, a lo sumo, han completado estudios primarios. 


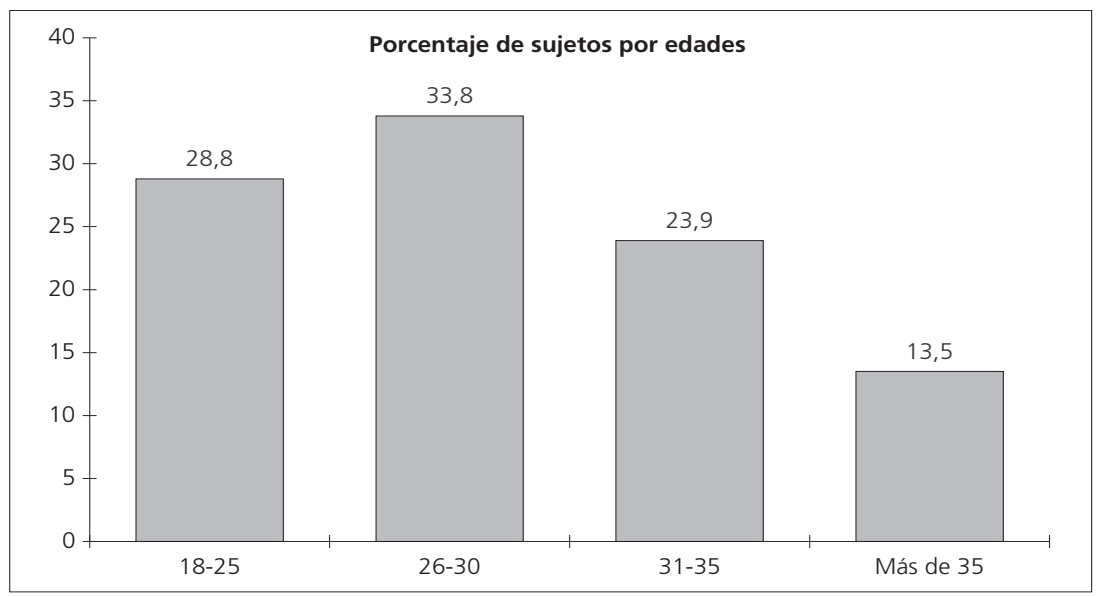

- El 34,4\% de los entrevistados ha estado escolarizado un período máximo de 9 años.

- La media de años escolarizados es de 10.

- Se da un alto índice de Abandono prematuro de los estudios: $74,7 \%$ afirma haber abandonado sus estudios. Antes de los 14 años lo hizo el $41 \%$ de éstos.

- El 93,2\% de los encuestados afirma no haber obtenido ningún Diploma, Certificado o Título el tiempo transcurrido desde que contactaron con el C.S.M.

- El 92,8\% de los entrevistados no está Matriculado actualmente en ningún centro escolar. Sólo 13 sí están matriculados actualmente.

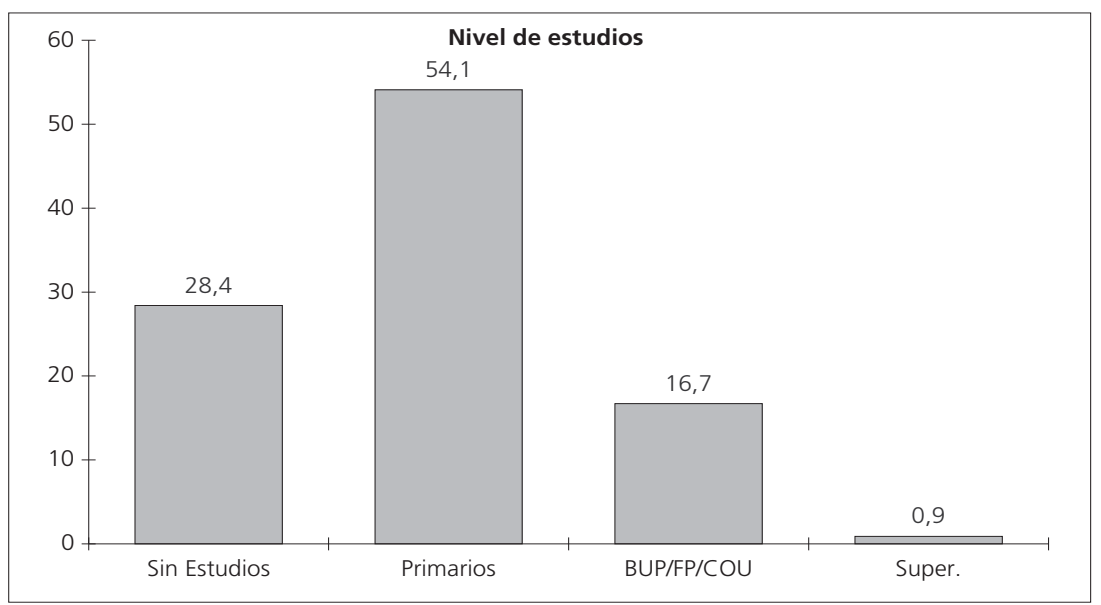


-Situación laboral:

- El 57\% de los entrevistados llegó a tener algún tipo de trabajo antes de ser atendido en los equipos de atención de drogodependencias.

- En el momento de realizar la entrevista disponían de tarea ocupacional $51,4 \%$ de ellos. Nótese que se trata de tarea ocupacional, es decir, de uno u otro modo, entendible como trabajo.

- En esa tarea ocupacional hay una enorme diversidad de cualificaciones profesionales u oficios: desde peón albañil, venta ambulante, temporeros, obrero de fábrica, agricultor, etc., pasando por portero de teatro, pastelero, camarero, montador eléctrico, peluquería, enconfrador, etc., hasta oficial $1 .^{a}$ de construcción, profesora de dibujo, imagen y vídeo.

-Interrelaciones entre los rasgos básicos de identificación:

- Mientras el 75\% de los que viven con su familia (casados) trabajan, tan sólo lo hacen el $45 \%$ de los que viven con sus padres (solteros).

- A medida que se eleva el nivel de estudios poseen, en mayor proporción, tarea ocupacional (el 66\% de los de estudios medios, frente al $37 \%$ de los de estudios primarios). Relación que se verifica también con número de años escolarizados, y la edad de abandono de los estudios.

- El $72 \%$ de los que no han sido detenidos en ninguna ocasión poseen tarea ocupacional frente al $45 \%$ de los que han sido detenidos.

\subsection{Consumo de drogas}

\section{CONSUmo de HeroínA}

- Antes de los 19 años, algo más del 52\% ya consumía heroína. La edad media de inicio al consumo de heroína es de 19,10 años.

- La vía de entrada más frecuente es la intravenosa, usada por el $77,4 \%$ de los encuestados.

-El 62,16\% dice no haber consumido heroína en la actualidad (entendido como en los últimos seis meses).

-El 64,9\% dice no haber consumido heroína en el último mes.

Como puede apreciarse es notoria la progresión descendente en el consumo de heroína con el paso del tiempo. 
—En el pasado, son todos los 222 consumidores de heroína,

- en la actualidad (últimos seis meses) desciende a 84 sujetos $(37,8 \%)$,

—y en el último mes son 78 sujetos $(35,1 \%)$.

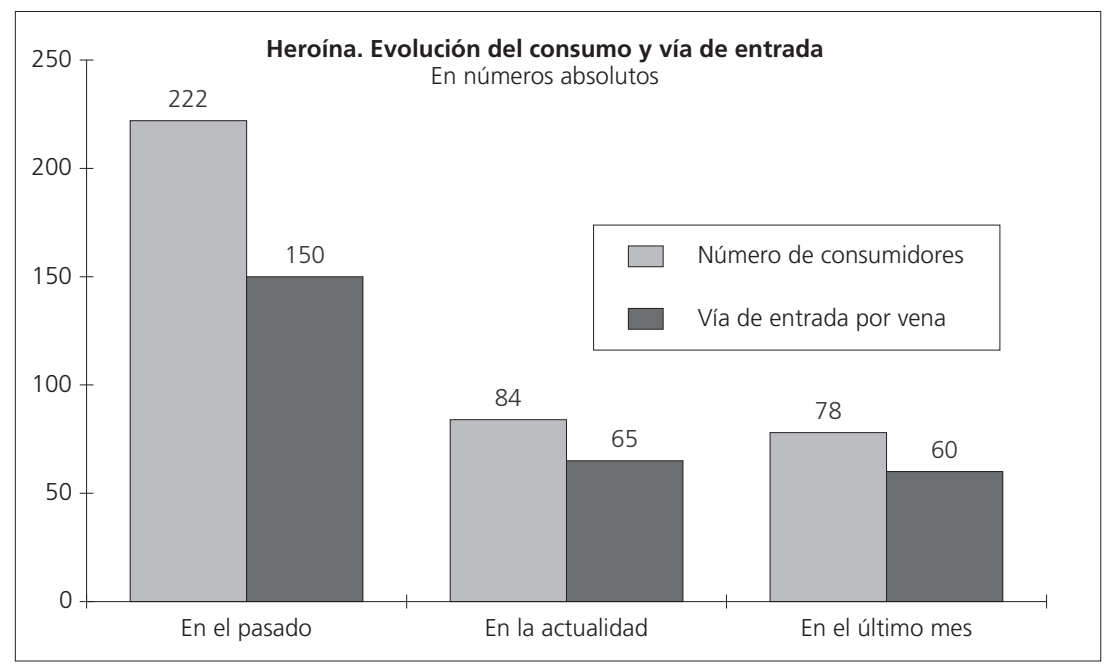

La progresión descendente de consumidores de heroína en porcentajes sobre los 222 sujetos es muy reveladora: de un $100 \%$ (222) de consumidores en el pasado desciende hasta un $37,8 \%$ en la actualidad (últimos seis meses) y hasta un $35,1 \%$ en el último mes. Esta tendencia ofrece un panorama notablemente positivo si se compara con otras realidades (siempre teniendo en cuenta las peculiaridades propias de cada grupo de adictos a la heroína estudiados) donde aparece que el consumo en el último mes de heroína alcanza hasta un 55,4\% de la muestra analizada (MARINA, 1993, p. 72).

Debe notarse, por otra parte, el escaso descenso de consumidores en el período de los últimos seis meses: de 84 bajan a 78 consumidores en el último mes, lo cual ratifica de alguna manera ese consistente hábito de consumo de heroína, esa adicción de difícil recuperación. Debe reconocerse que de los 6 sujetos que abandonan la heroína 4 pertenecen al programa de Metadona. La lentitud de rehabilitación, por tanto, es un hecho pero, los progresos aun siendo escasos, son tangibles y progresivos como sucede y se comprueba en otros estudios. 
El dato del consumo del último mes, sobre todo, se sitúa entre los hallados por el «Drug Dependence Clinics» de Londres o por el DARP o en el estudio de Asturias (MARINA, 1993, p. 95) con 31\%, 61\% y $44,6 \%$ respectivamente. En el presente estudio, el porcentaje se sitúa en el $35,1 \%$. Quizás pueda considerarse bajo, pero los análisis de orinas sucias, como parámetro de control, asevera esta cifra.

Atendiendo a los rasgos básicos de identificación, resulta según los datos de la muestra:

-65 hombres y 13 mujeres.

-50 viven en Logroño. 27 viven en los pueblos.

- 51 están solteros y 16 casados.

-48 viven con sus padres. 17 viven con la familia propia.

-24 «sin estudios». 43 de estudios primarios. 10 estudios medios.

—47 no tienen trabajo. 30 sí tienen trabajo.

La frecuencia del consumo de ese $35,1 \%$ de consumidores en el último mes se distribuye prácticamente por igual entre un $18 \%$ de consumidores diarios ( 1 o más veces al día) y un $17,1 \%$ de consumidores esporádicos (menos de $1 \mathrm{vez}$ al día).

En cualquier caso, la vía de administracion según aparece en la tabla, es fundamentalmente intravenosa: 60 de los 78 sujetos, es decir, $76,9 \%$. En este tema de la vía de administración no ha habido una mejora sustancial, quizás incluso puede hablarse de lo contrario. La razón, encontrada también en otros estudios, se mueve en el ámbito del reconocimiento de la presencia de un grupo con un hábito de adicción ya muy arraigado en el tiempo y, además, administrándosela por vena que, dicho de otra manera, constituirían el bloque de peor pronóstico de recuperación.

Una muy buena parte de ese bloque está incluido en el programa de Metadona. Son 44 de los 78, es decir, el 56,4\%. Lo más destacable es su práctica de administración. Estos son los más inveterados usuarios de la vía intravenosa. 36 de los 44, es decir, el 81,8\% lo realizan de esa manera.

La gran mayoría de los consumidores en el último mes son policonsumistas: $83,3 \%$ (65 de los 78 sujetos). Se dividen así:

- consumidores de Heroína + Cocaína $=23(10,4 \%)$

- consumidores de Heroína + Otras drogas $=42(18,9 \%)$

— consumidores de sólo Heroína $=13(5,9 \%)$ 
Concretamente la combinación del uso de la heroína más la cocaína se distribuye según la siguiente tabla:

\begin{tabular}{|c|c|c|c|}
\hline & & & \\
\hline & & Esporádico & Más de 1 al día \\
\hline Cocaína & Esporádico & 9 & 11 \\
\hline & Más de 1 al día & 0 & 3 \\
\hline & & 9 & 14 \\
\hline
\end{tabular}

Destaca, por una parte, la mayoría de los del consumo de heroína 1 o más veces al día (14) y de los del consumo de cocaína de forma esporádica (20). Lo más frecuente, por otra parte, es el consumo diario de heroína y esporádico de cocaína (11) no encontrándose ningún sujeto de consumo esporádico de heroína y diario de cocaína.

Analizando con más detalle a este subgrupo de policonsumidores de heroína más cocaína resulta el siguiente perfil:

\begin{tabular}{|l|l|l|}
\hline-21 son hombres & -21 viven en Logroño & -16 son solteros \\
\hline-15 viven con padres & $\begin{array}{c}-19 \text { tienen a lo más estudios } \\
\text { primarios }\end{array}$ & -16 abandonan estudios \\
\hline-16 sin trabajo & -14 del programa de Metadona & \multicolumn{1}{|c}{} \\
\hline
\end{tabular}

Este perfil va a ser bastante repetitivo en algunas otras áreas. Vienen a señalar los parámetros básicos sobre los cuales se cimenta una adicción consolidada, habitual y de difícil ruptura o modificación. Aquí no entran prioritariamente los de mayor edad, los de pueblos, los de estudios superiores a los primarios, los que tienen trabajo, los que viven con la familia, etc.

Los 42 sujetos policonsumidores de heroina + otras drogas $(18,9 \%)$ dividen su adicción de la siguiente forma:

- heroína + tranquilizantes

- heroína + alcohol

$=4$

- heroína + cannabis

$=7$

- heroína + alcohol + cannabis

$=10$

$=9$

- heroína + alcohol + cannabis + tranquilizantes $=5$

-heroína + otras combinaciones $\quad=7$

Consumen sólo heroína 13 sujetos. 
Los 42 sujetos presentan unos hábitos de policonsumo de heroína más otras drogas muy variados y diferentes aunque pudiera subrayarse como acompañantes de una u otra manera habituales el alcohol y el cannabis. A todos ellos debería añadírseles el tabaco dado su carácter general de consumo.

\section{CONSUMo DE COCAÍNA}

—El 91,2\% de los encuestados afirma haber consumido cocaína en alguna ocasión.

-El 55,2\% ha consumido cocaína, de forma regular, antes de los 19 años.

- El 77\% afirma no haber consumido cocaína durante el período actual (entendido como los últimos seis meses).

-El 83,4\% afirma no haber consumido cocaína en el último mes.

—La edad media de inicio a la cocaína es de 19,03 años.

Lo más reseñable de los datos anteriores es el reconocimiento de una progresión descendente de consumidores:

- de los 202 sujetos que han consumido alguna vez,

- a los 51 en los últimos seis meses,

— y a los 37 consumidores en el último mes.

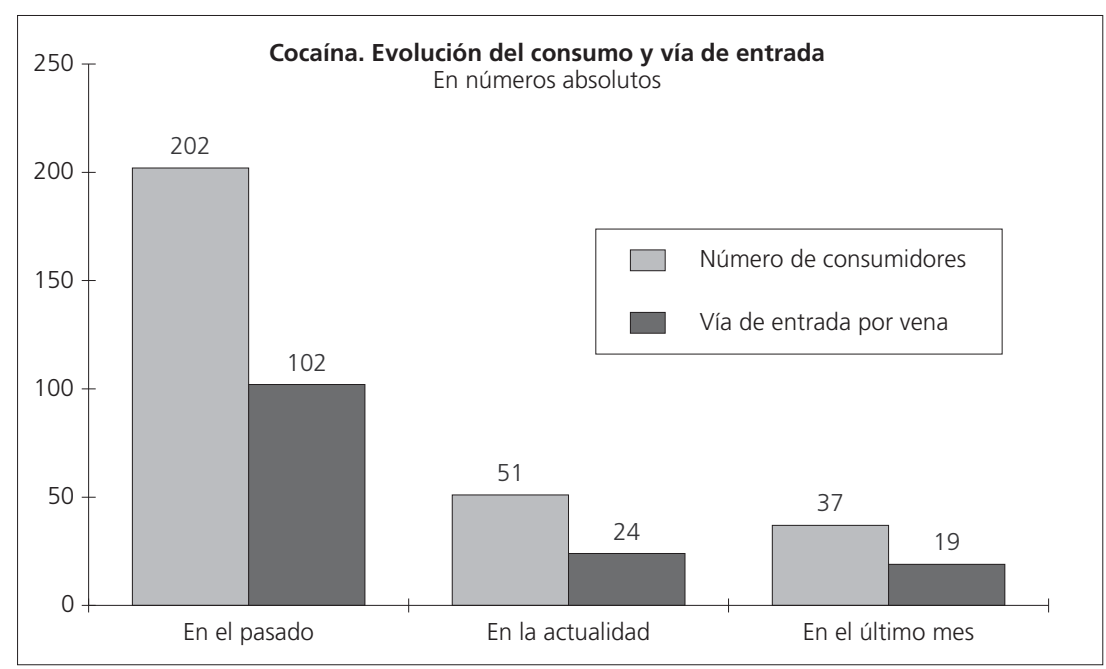


La progresión descendente de consumidores de cocaína en porcentajes sobre los 222 sujetos es muy reveladora: de un 91,0\% (202) de consumidores en el pasado desciende hasta un $23,0 \%$ en los últimos seis meses y hasta un $16,7 \%$ en el último mes. Esta tendencia puede considerarse notablemente positiva si se compara con otras realidades (siempre teniendo en cuenta las peculiaridades propias de cada grupo de adictos a la cocaína estudiados) donde aparece que el consumo en el último mes de cocaína alcanza hasta un $33,1 \%$ de la muestra analizada (MARINA, 1993, p. 74).

Como ocurre en el caso de la heroína, el descenso de consumidores de cocaína desde un 91,0\% que consumían en el pasado hasta el $23 \%$ de consumidores en la actualidad (últimos seis meses) debe comprenderse desde varias perspectivas. En primer lugar, desde la diferenciación entre haberla consumido en el pasado alguna vez y seguir consumiéndola en la actualidad (últimos seis meses) de manera más o menos esporádica. El pasado, efectivamente, significa hace tiempo. Hasta llegar a la actualidad han sucedido multitud de episodios con capacidad de cambiar los hábitos de consumo. Los mismos drogadictos confiesan haber cambiado de hábitos y haber superado ciertos consumos porque costaba mucho dinero, porque han sufrido episodios de sobredosis, de síndromes de abstinencia, etc., y porque llevaban mala vida. Por otra parte, el ir creciendo en edad parece estar acompañado de una nueva visión de su problemática situación y cierto cansancio de su drogadicción rutinaria. En algunos, se une a este proceso su paulatina maduración hacia la negación de su drogodependencia y sus deseos de recuperación. En algunos otros, también se añade su pertenencia a un determinado tratamiento con capacidad para ir recuperando al menos a los más decididos y a los más rehabilitables. Que la abstinencia de cocaína, como en el caso de la heroína, sea definitiva es otro grave problema de difícil predicción y explicación. Los datos, de todos modos, corroboran el descenso de consumidores de cocaína desde el pasado hasta la actualidad (últimos seis meses).

Respecto a la vía de entrada por vena no hay variación proporcional significativa entre los tres períodos. De cada dos consumidores 1 lo hizo por vena, lo hacía así hace seis meses y lo sigue haciendo en el último mes. En referencia al pasado, por otra parte, se percibe un cierto aumento en hacerlo por la nariz tanto en la actualidad (últimos seis meses) como en el consumo del último mes en detrimento de hacerlo por boca. En cualquier caso, estas tendencias sobre la vía de entrada deben tomarse con cautela por estar basada en un número reducido de drogodependientes consumidores de cocaína sobre todo en el último mes. 
La frecuencia del consumo en el último mes es la siguiente: 33 (15\%) la consumen esporádicamente y tan sólo $4(1,9 \%)$ la consumen a diario una o más veces.

Sea como fuere la frecuencia de consumo del uso de cocaína en el último mes está muy relacionada con el policonsumo.

- Consumidores de heroína + cocaína $=23$

- Consumidores de cocaína + otras drogas $=14$

La explicación sobre los policonsumistas de heroína más cocaína está hecha en el apartado anterior. Sobre los 14 policonsumidores de cocaína más otras drogas puede confirmarse la gran variabilidad de consumo. Algunos pocos consumen también alcohol, por supuesto tabaco y otros cannabis.

Aunque tan sólo son 37 sujetos los consumidores de cocaína en el último mes hay ciertas diferencias constatables entre ellos.

-30 viven en Logroño y 7 viven en pueblos.

- Sólo 6 atendidos en comunidad terapéutica son consumidores frente a 31 no atendidos.

3. Consumo de otras dRogas

\begin{tabular}{|l|r|r|r|r|c|}
\cline { 2 - 5 } \multicolumn{1}{c|}{} & \multicolumn{2}{c|}{$\begin{array}{c}\text { Consumida } \\
\text { alguna vez }\end{array}$} & \multicolumn{2}{c|}{$\begin{array}{c}\text { Consumida en } \\
\text { el último mes }\end{array}$} & \multirow{2}{*}{$\begin{array}{c}\text { Edad Media } \\
\text { de Inicio }\end{array}$} \\
\cline { 2 - 5 } & \multicolumn{1}{c|}{$\mathrm{N}$} & $\%$ & \multicolumn{1}{c|}{$\mathrm{N}$} & $\%$ & \\
\hline Tabaco & 218 & 98 & 214 & 96 & 12,86 años \\
\hline Cannabis & 212 & 96 & 95 & 43 & 15,27 años \\
\hline Alucinógenos & 169 & 76 & 4 & 2 & 17,12 años \\
\hline Tranquilizantes & 188 & 85 & 38 & 17 & 20,21 años \\
\hline Otros opiáceos (Buprex) & 146 & 66 & 9 & 4 & 21,29 años \\
\hline Anfetaminas & 156 & 70 & 9 & 4 & 18,54 años \\
\hline Disolventes & 32 & 14 & 1 & 0,5 & 12,59 años \\
\hline
\end{tabular}

La tabla está confeccionada a modo de resumen con la intención fundamental de dejar en evidencia el carácter de drogas acompañantes de las dos fundamentales como son la heroína y la cocaína. 
Todas, menos los disolventes, han sido consumidas en mayor o menor medida alguna vez, pero el consumo en el último mes descienden sustancialmente menos el tabaco y el cannabis. Estas son precisamente las drogas más acompañantes añadiendo, aunque en menor medida, los tranquilizantes.

\section{Consumo de Alcohol}

- La práctica totalidad de los encuestados afirma haber consumido alguna vez alcohol $(91,9 \%)$.

- El 54\% de los encuestados afirma haber consumido regularmente alcohol antes de los 15 años y a los 16 años es el 82\%.

- La media de edad en el inicio al alcohol es de 15,11 años.

-El 43,2\% de las personas encuestadas asegura no haber consumido alcohol en la actualidad (últimos seis meses).

El siguiente gráfico expone los porcentajes de consumidores de alcohol en la actualidad (últimos seis meses) en función de la temporalidad: entre semana, fin de semana y a la semana (como promedio ponderado de los dos anteriores) y en función de la cantidad bebida oscilando entre Abstemios y Excesivos.

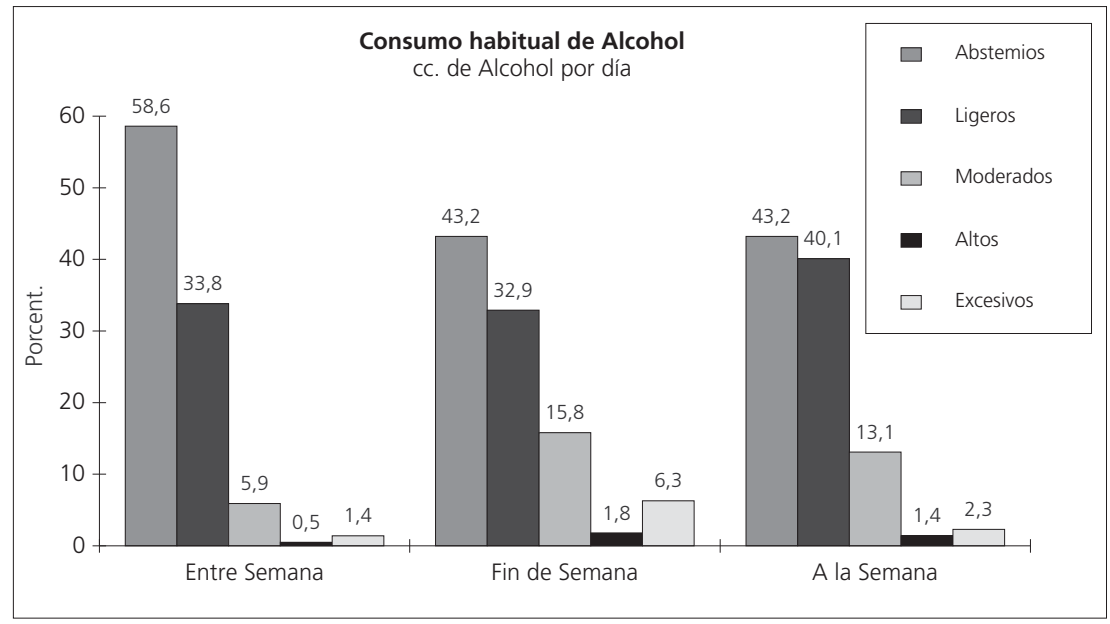

En el tema del alcohol es difícil hacer comparaciones con los resultados de otros estudios por la diferente técnica usada para medir las cantidades consumidas. Por otra parte, tampoco parece lógico comparar el consumo de alcohol en la población general con el consumo de alcohol en el colectivo de drogodependientes. 
El 43,2\% de abstemios en la actualidad (últimos seis meses) y el $57,3 \%$ también de abstemios en el último mes son cifras francamente elevadas de abstinencia de alcohol. Independientemente de otras cifras de diferentes estudios donde resultan algo más elevadas, el colectivo de drogodependientes del presente estudio presenta un grupo de 133 sujetos inscritos en algún programa: metadona, naltrexona y libre de drogas. Estos tratamientos impiden y casi apartan de una u otra manera el consumo de alcohol.

Si se incluyera junto a los abstemios a los ligeros (de 1 a 25 cc., lo cual supone un consumo ciertamente escaso entendido en otros estudios como «ocasional») el porcentaje se situaría en algo más del $80 \%$, lo cual permite afirmar en el presente estudio la ausencia del alcohol como problema añadido al consumo de drogas. También pudiera entenderse como un síntoma de recuperación general al menos en esta área. Durante el fin de semana la situación varía por la presencia de aproximadamente un $25 \%$ de bebedores moderados, altos o excesivos, tendencia por otra parte que se cumple tanto en el consumo de alcohol en la población general como, sobre todo, entre los jóvenes.

\section{Policonsumo}

La tesis más frecuentemente defendida (MARINA, 1993, p. 74) es la tendencia al policonsumo por parte de los drogodependientes. La tabla siguiente referida al consumo en el último mes proporciona alguna matización según los datos de este estudio.

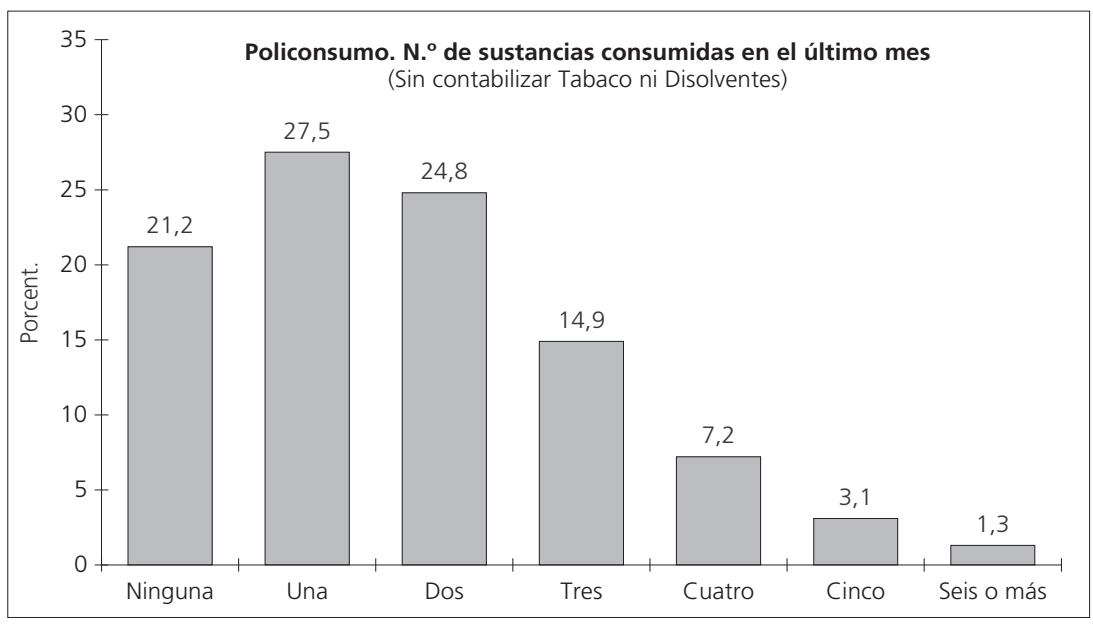


Como se ve, la tabla no considera ni el tabaco ni los disolventes. El tabaco por ser consumida prácticamente por todos. Y los disolventes por no ser consumida prácticamente por nadie.

En primer lugar, destaca el porcentaje de Abstinentes en el último mes hasta situarse en un $21,2 \%$. Por otro, los porcentajes relativamente mayoritarios se colocan en el consumo de una sustancia (27,5\%). Sumando las dos cantidades supone un $48,7 \%$ del total. Es decir, prácticamente la mitad de los entrevistados no son policonsumistas.

De otra parte, sin embargo, el 51,3\% consumen dos o más sustancias. Destaca el dato del 26,57\% de consumidores de 3 sustancias o más, es decir, 1 de cada 4 sujetos, podría definirse como policonsumista generalizado.

La siguiente distribución clarifica los tipos de consumo más relevantes incluyendo a los abstinentes y en comparación con los obtenidos en el Estudio de Asturias (MARINA, 1993, p. 74) sin considerar el tabaco ni los disolventes:

\begin{tabular}{|l|r|r|r|r|}
\cline { 2 - 5 } \multicolumn{1}{c|}{} & \multicolumn{2}{c|}{$\begin{array}{c}\text { Presente } \\
\text { Estudio }\end{array}$} & \multicolumn{2}{c|}{$\begin{array}{c}\text { Estudio de } \\
\text { Asturias }\end{array}$} \\
\cline { 2 - 5 } \multicolumn{1}{c|}{} & $\mathrm{N}$ & \multicolumn{1}{c|}{$\%$} & $\mathrm{~N}$ & $\%$ \\
\hline Abstinentes & 47 & 21,2 & 23 & 16,5 \\
\hline Heroína + Cocaína & 23 & 10,2 & 39 & 28,1 \\
\hline Heroína + otras drogas & 55 & 24,8 & 39 & 28,1 \\
\hline Cocaína + otras drogas & 14 & 6,3 & 13 & 9,4 \\
\hline Otras drogas & 83 & 37,4 & 25 & 18,0 \\
\hline
\end{tabular}

Los datos dejan claras dos realidades: el porcentaje de abstinentes es mayor en el presente estudio de La Rioja que en el de Asturias $(21,2 \%$ frente a $16,5 \%)$ y el consumo de heroína y cocaína es inferior. En el caso de «otras drogas» el porcentaje del presente estudio es bastante superior pero no debe entenderse como un porcentaje de policonsumistas dado que en el mismo están incluidos aquellos consumidores de una sola droga, principalmente, cannabis o alcohol cuyo porcentaje asciende al 21,6\%. Por tanto, en ese concepto de «otras drogas» el nivel de policonsumistas llega tan sólo al 15,8\%. El policonsumismo, por tanto, en el presente estudio, aun siendo una realidad, no alcanza la categoría de característica definitoria del tipo de consumo de los adictos a la heroína. 
El siguiente cuadro aporta más detalles del tipo de policonsumo sobre todo referido a las drogas acompañantes de la heroína.

\begin{tabular}{|l|r|r|}
\cline { 2 - 3 } \multicolumn{1}{c|}{} & N & $\%$ \\
\hline Abstinentes & 47 & 21 \\
\hline Sólo heroína & 13 & 6 \\
\hline Heroína + cocaína & 23 & 10 \\
\hline Heroína + tranquilizantes & 4 & 2 \\
\hline Heroína + alcohol & 7 & 3 \\
\hline Heroína + cannabis & 10 & 4 \\
\hline Heroína + alcohol + cannabis & 9 & 4 \\
\hline Heroína + alcohol + cannabis + tranq. & 5 & 2 \\
\hline Heroína + otras combinaciones & 7 & 3 \\
\hline Cocaína más otras drogas & 14 & 6 \\
\hline Otras combinaciones de drogas & 83 & 37 \\
\hline TOTAL & 222 & 100 \\
\hline
\end{tabular}

\section{ORdEN DEL CONSUMO DE DROGAS}

Esta pregunta del cuestionario tiene el sentido de averiguar el itinerario personal de consumo seguido hasta terminar en la heroína y no tanto búsqueda de causalidades estrictas entre primeros consumos y consumos posteriores.

La primera sustancia en el orden de consumo es el tabaco, con la que empezaron el 71,6\% (sobre 222). Le sigue, como primera sustancia en el orden de consumo aunque a enorme distancia, el alcohol, con el que empezaron el $22,5 \%$ de ellos. las:

A partir de aquí puede constatarse la existencia de dos rutas parale-

a) Por un lado los que como segunda sustancia en el orden de consumo señalan el cannabis pasan ya como tercera sustancia a la heroína.

b) Los que, como segunda sustancia, señalan el alcohol, y apuntan el cannabis como tercera y llegan más tarde a la heroína. 
7. EDAD DE INICIO

El gráfico siguiente ofrece la edad media de inicio a las distintas sustancias:

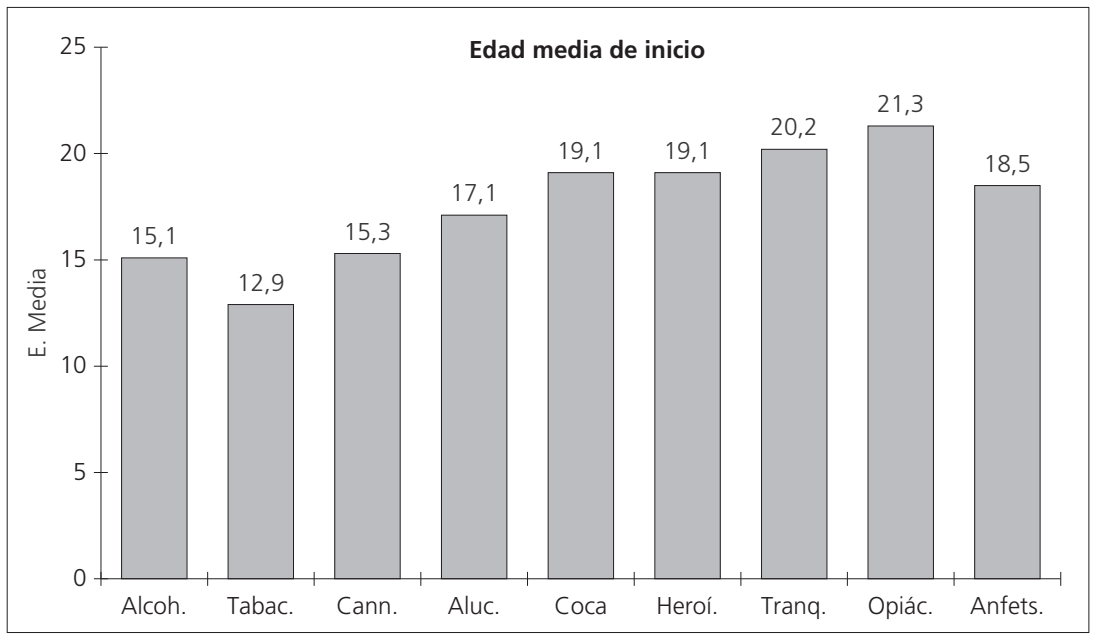

Este gráfico de edades de inicio presenta una fuerte concordancia con el orden de consumo de las diferentes drogas: Tabaco, Acohol, Cannabis y Heroína junto con Cocaína. También se consumen relativamente pronto los Alucinógenos pero los propios entrevistados no la consideran como una droga importante en su itinerario hasta la heroína.

La edad de inicio al consumo de heroína influye en el consumo del último mes. El análisis estadístico de los datos revela efectivamente que el grupo con inicio al consumo de heroína menor de 16 años es el que en mayor proporción sigue consumiendo en el último mes $(41,9 \%)$. Los que se iniciaron con más de 17 años consumen menos heroína (28,6\%). Como si un inicio a la heroína en edad muy temprana física y psíquicamente suponga un verdadero enganche prolongado en el tiempo. Por otra parte, ese inicio a edad temprana significa de alguna manera un entorno familiar y parental no precisamente saludable y estabilizado. Si se comienza antes de los 16 años a consumir heroína quiere decir que dos o tres años antes, es decir a los 13 o 14 años, ya se había iniciado en otras drogas.

A pesar de haber relación entre edad actual y edad de inicio, por ejemplo los mayores de 36 años se inician al consumo de heroína a los 24 años y los menores de 25 años a los 17, no puede hablarse de relación entre edad actual y consumo de heroína. 


\subsection{Tratamientos previos y tratamientos actuales}

\section{Modalidades de tratamientos PReVios}

Antes de entrar en contacto con el Equipo de Atención de Drogodependencias, es decir antes del 1 de julio de 1993, ha habido ciertamente una gran variedad de tipos de tratamientos.

\begin{tabular}{|l|c|c|c|c|}
\cline { 2 - 3 } \multicolumn{1}{c|}{} & \multicolumn{2}{c|}{ Atendidos } & \multirow{2}{*}{$\begin{array}{c}\text { Promedio } \\
\text { Te veces }\end{array}$} & $\begin{array}{c}\text { Número } \\
\text { máximo }\end{array}$ \\
\cline { 2 - 3 } & $\mathrm{N}$ & $\%$ & 3,11 & 12 \\
\hline Servicio Ambulatorio & 76 & 34 & 2,10 & 7 \\
\hline Comunidad Terapéutica & 71 & 32 & 2,03 & 9 \\
\hline Unidad Desintox. Hospital. & 64 & 29 & 1,23 & 3 \\
\hline Tratamiento con metadona & 49 & 22 & 2,25 & 9 \\
\hline Otros Servicios & 64 & 29 & & \\
\hline
\end{tabular}

La experiencia profesional en este campo conduce a una afirmación muy real: "siempre se hace bastante pero se podría hacer más». En este sentido debe entenderse ese 45,1\% (100 sujetos) tratados y atendidos más de una vez y ese $35,1 \%$ (78 sujetos) nunca atendidos, más los 19,8\% (42 sujetos) atendidos una sola vez y ya no han vuelto más.

Los no atendidos o los menos atendidos presentan una tipología coincidente con SELLS y SIMPSON (1976) caracterizada sociodemográficamente por varios parámetros: provenir de familias desajustadas, mujeres, «sin estudios», residentes en pueblos, es decir, lejos de la ciudad, con una edad de inicio temprano al consumo de heroína y sin padecer hepatitis, VIH, SIDA u otras patologías orgánicas.

La red pública de servicios socio-sanitarios está abierta en principio a todo aquél que lo necesite y lo pida. Muchos de los drogodependientes en virtud de su mentalidad y sus decisiones, sin duda influidas por su status personal y social ni tan siquiera se han acercado. Este hecho, como normalmente sucede en casi todas las organizaciones de servicios, suele servir de acicate y estímulo para la superación, la reprogramación, la rentabilización óptima de los recursos humanos y financieros de que dispone y, en definitiva, para estar en permanente alerta para realizar los cambios pertinentes y adaptarse mejor a las nuevas circunstancias. Esta fenomenología organizacional se ha dado en la Comunidad de La Rioja con nuevos planes, mejora de los existentes, reprogra- 
maciones más ajustadas a la demanda, etc., porque en última instancia (SANCHEZ CARBONELL, 1989) las diversas modalidades de tratamiento son, en un nivel $\mathrm{u}$ otro, eficaces y traen consecuencias positivas a corto, medio o largo plazo según sea el tema de que se trate.

\section{ATENCIÓN EN URGENCIAS}

El 57,3\% (108 sujetos) afirma haber sido atendido en urgencias en alguna ocasión por algún motivo en relación con las drogas y, además, con un promedio de veces atendido de hasta 6 como ocurre en el caso de «síndrome de abstinencia». Son cifras altas o muy altas pero, sin embargo, plausibles por lo que de riesgo vital tienen los sujetos drogodependientes.

\begin{tabular}{|l|c|c|c|c|}
\cline { 2 - 4 } \multicolumn{1}{c|}{} & \multicolumn{2}{|c|}{ Atendidos } & \multirow{2}{*}{$\begin{array}{c}\text { Promedio } \\
\text { de veces }\end{array}$} & $\begin{array}{c}\text { Número } \\
\text { máximo }\end{array}$ \\
\cline { 2 - 5 } \multicolumn{1}{c|}{} & $\mathrm{N}$ & $\%$ & 2,23 & 15 \\
\hline Por Sobredosis & 53 & 24 & 5,87 & 38 \\
\hline Por Síndrome de Abstinencia & 78 & 35 & 1,92 & 10 \\
\hline Por Patología Orgánica Asociada & 63 & 28 & \\
\hline
\end{tabular}

La tipología del sujeto adicto atendido en urgencias se parece al atendido en los servicios ordinarios sobresaliendo sobre todo la característica de no tener trabajo y de vivir en Logroño. En este último caso no se trata de afirmar la existencia de diferentes episodios graves en la ciudad y en el pueblo sino tan sólo de la proximidad geográfica al centro de urgencias. El no tener trabajo, muy traducible por no tener responsabilidades sociolaborales y consecuentemente carecer de ilusión por enderezar una vida normalizada, se asienta como variable importante para entender la situación peligrosa en que puede devenir el adicto $\mathrm{y}$, por tanto, en la necesidad de acudir a urgencias ante episodios de sobredosis, de patología orgánica asociada y también por síndrome de abstinencia probablemente iniciado por un «ya basta» personal o familiar ante una situación de bache profundo y prolongado.

En el mismo sentido debe hablarse de la influencia del ajuste social sobre el acudir a urgencias. Quienes han sido detenidos alguna vez, quienes han sido presentados más de cinco veces ante el juez, quienes más tiempo han estado en la cárcel, etc., son los que en mayor medida solicitan la atención en urgencias así como también en tratamientos ordinarios. 
3. Tratamientos En CURSO EN El Período 30-JUnio-1993

AL 30-JUNIO-1994.

\section{Los Contactos con el Equipo de Atención de Drogodependencias}

El número de drogadictos con contacto con el Equipo de Atención de Drogodependencias antes del 30-junio-93 son 165. Los que tuvieron su primer contacto posteriormente a tal fecha son 39. De los 18 restantes no se tienen datos acerca de la fecha.

En cualquiera de los dos casos, se realizó una valoración física adecuada al 88,5\% (sobre 172 sujetos de los que se tienen datos), un $25,6 \%$ fue enviado a desintoxicación ambulatoria y el $6,1 \%$ a una desintoxicación hospitalaria.

\begin{tabular}{|l|r|r|r|r|r|c|}
\cline { 2 - 7 } \multicolumn{1}{c|}{} & \multicolumn{5}{c|}{ Iniciaron el Tratamiento } \\
\cline { 2 - 8 } \multicolumn{1}{c|}{} & \multicolumn{2}{|c|}{ Sí } & \multicolumn{2}{c|}{ No } & \multicolumn{2}{c|}{ No hay datos } \\
\cline { 2 - 7 } \multicolumn{1}{c|}{} & $\mathrm{N}$ & $\%$ & $\mathrm{~N}$ & $\%$ & $\mathrm{~N}$ & $\%$ \\
\hline Contacto antes de 30-junio-1993 & 125 & 76 & 7 & 4 & 34 & 20 \\
\hline Contacto después al 30-junio-1993 & 29 & 74 & 6 & 15 & 4 & 10 \\
\hline No hay datos & 5 & 29 & 0 & 0 & 12 & 71 \\
\hline
\end{tabular}

El porcentaje de los que iniciaron tratamiento es $71,6 \%$ (159 sujetos) de los 222 entrevistados tras contactar con el Equipo de Atención de Drogodependencias. Este dato supera al 54,5\% del Estudio de Asturias (MARINA, 1993, p. 91) quizás debido a la diferente comprensión entre contactar con el equipo y solicitar tratamiento de forma directa. Los que no quisieron iniciar tratamiento fueron tan sólo 13 sujetos $(5,9 \%)$. De 50 no se tienen datos.

Los 159 inscritos en uno u otro momento a tratamiento se reparten así: 121 a Metadona, 29 a Naltrexona y 9 a Libre de Drogas.

\section{Número de Consultas y Tiempo de Retención en los Programas de Tratamiento}

De los 222 entrevistados, el $71,6 \%$ ha acudido a 20 o menos consultas, frente al restante $28,4 \%$, que ha tenido más de 20 consultas. Son estos últimos los que presentan una muy notoria variabilidad porque se dan casos de 21 consultas y otros, sin embargo, llegan hasta las 138 consultas. 
El promedio de consultas por sujeto es 19,96 durante el período analizado. Esta cifra puede entenderse quizás de diferentes formas en virtud de la perspectiva propia del observador-analista. Quizás sea demasiado alta por cuanto con menos visitas el drogadicto debería estar ya colocado en la dirección adecuada hacia su rehabilitación, o quizás sea demasiado baja por cuanto la problemática de la drogadicción necesita mucha orientación, bastante seguimiento, horas de escucha y atención hasta conseguir un objetivo que, muchas veces, es pequeño y de corto alcance dadas las circunstancias. En cualquier caso, tras analizar los datos estadísticamente van más a consulta quien más disposición presenta hacia la prevención no tanto quien más lo necesita: los no seroprevalentes al VIH, los no diagnosticados de SIDA, los sin hepatitis, los de menor relación con la justicia y los que menos han ido a la cárcel. También acuden en mayor proporción los posibles casos psicopatológicos y los bebedores moderados, altos o excesivos.

La media de días de Tiempo de Retención en los Programas de Tratamiento es de 270,0 (sobre 151 respuestas) pero con una desviación típica enorme, señal de la gran variabilidad de permanencia en tratamiento con un mínimo de 1 día y un máximo de 1.040 días.

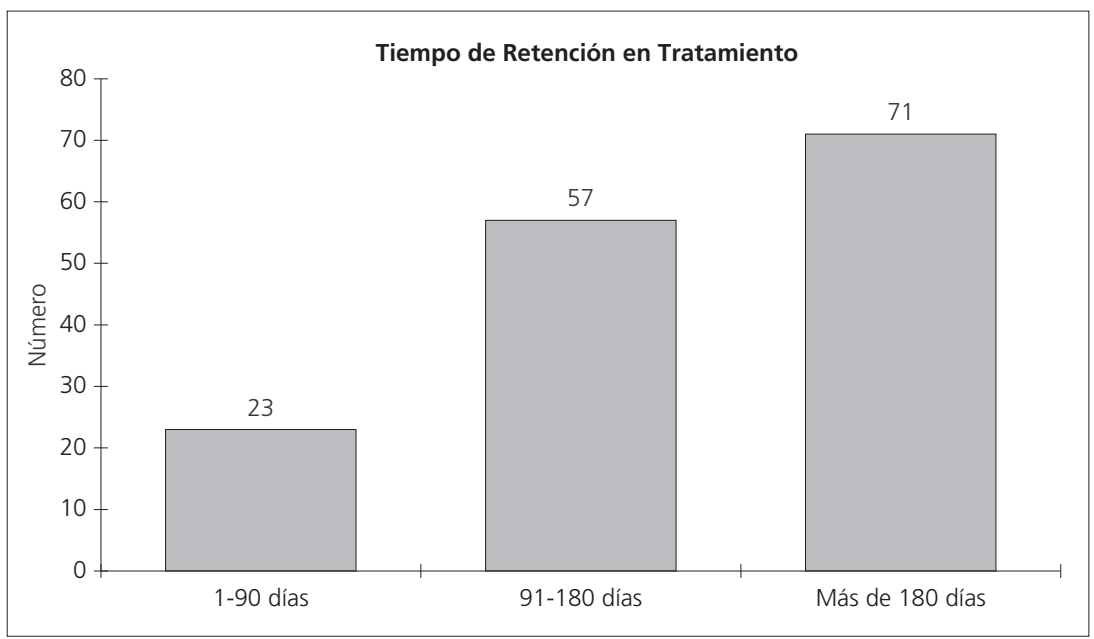

Prácticamente la mitad (71 sujetos, 47,0\%) presenta un tiempo de permanencia en el tratamiento de más de 6 meses y tan sólo $23(15,2 \%)$ permanecen menos de tres meses. En comparación a otros estudios 
(MARINA, 1993, p. 92) como el de Asturias, este dato sobrepasa con mucho al $18,7 \%$ que él encuentra en su muestra con un tiempo de retención superior a los seis meses. Por contra, el 51,1\% no llega al mes. Desde otra perspectiva y a tenor de las averiguaciones ya realizadas (VAILLANT 1966) estos datos del presente estudio son positivos por la influencia de la variable «tiempo de retención» sobre el proceso de rehabilitación del drogadicto a pesar del peso negativo de ciertas características sociodemográficas de los sujetos, relación que se cumple en esta investigación concretamente entre el colectivo perteneciente al programa de Metadona.

\begin{tabular}{|l|c|}
\cline { 2 - 2 } \multicolumn{1}{c|}{} & \multicolumn{1}{c|}{$\begin{array}{c}\text { Promedio } \\
\text { de consultas }\end{array}$} \\
\hline Metadona & 17,5 \\
\hline Naltrexona & 39,6 \\
\hline Libre de drogas & 16,7 \\
\hline Abandonos & 28,7 \\
\hline
\end{tabular}

\begin{tabular}{|c|}
\hline $\begin{array}{c}\text { Promedio } \\
\text { de días } \\
\text { de tratamiento }\end{array}$ \\
\hline 268,3 \\
\hline 409,5 \\
\hline 104,3 \\
\hline 114,9 \\
\hline
\end{tabular}

Los del programa de Naltrexona presentan un promedio más alto (409 días) y los de Metadona llegan a los 268,3 días. Los abandonos, lógicamente, disminuyen su permanencia hasta los 114,9 días, lo cual sin embargo, significa prácticamente tres meses.

Dos factores inciden especialmente en el tiempo de retención: el ajuste social medido en los últimos tres meses (no se encuentra relación entre ajuste pasado y retención) y el Estado de Salud Orgánico. Quienes mejor ajuste social presentan en esos últimos tres meses, quien no tiene su vida interrumpida de una $u$ otra manera por causas judiciales causadas por conductas desordenadas y delictivas puede dedicarse, si mantiene el interés, por seguir un determinado tratamiento. Quienes, por otro lado, son seroprevalentes al VIH, o están diagnosticados de SIDA y los de Hepatitis se mantienen en tratamiento durante mayor período de tiempo no sólo quizás buscando atención sino también comprensión a su problemática de salud. Es destacable la no influencia del estado de salud psicopatológico sobre el tiempo de retención. Puede ser la inconsciencia o su propia situación de desequilibrio la generadora de una desvaloración del tratamiento y su consecuentemente abandono del mismo. 
Situación actual al 30 de junio de 1994

\begin{tabular}{|c|c|c|}
\hline SITUACION & $\mathrm{N}$ & $\%$ \\
\hline En tratamiento: & 133 & 60 \\
\hline —Metadona & 114 & 51 \\
\hline -Naltrexona & 16 & 7 \\
\hline -Libre de drogas & 3 & 2 \\
\hline
\end{tabular}

\begin{tabular}{|c|c|c|}
\hline Sin tratamiento: & 68 & 31 \\
\hline _Alta médica & 6 & 3 \\
\hline —Trasladado & 2 & 1 \\
\hline —Abandonos de tratamiento & 29 & 13 \\
\hline —Sin aceptar tratamiento & 31 & 14 \\
\hline En ARAD & 4 & 2 \\
\hline En Proyecto Hombre & 5 & 2 \\
\hline En Prisión & 12 & 5 \\
\hline TOTAL & 222 & \\
\hline
\end{tabular}

La tabla puede ser completada con algún detalle más.

1. Reciben algún tratamiento o están en programa 133 sujetos, el $60 \%$ del total de adictos a la heroína.

-Los programas son:

- metadona: 114 sujetos.

- naltrexona: 16 sujetos.

- libre de drogas: 3 sujetos.

- La dosis media de metadona en miligramos que toman 111 sujetos de los que se dispone información es de 57,47 miligramos.

2. No reciben tratamiento 68 sujetos, el $31 \%$ del total. Entre ellos se encuentran:

-6 sujetos $(2,7 \%)$ con alta médica.

-2 sujetos $(1 \%)$ trasladados a otra localidad y sin tratamiento en la red. 
-29 (13\%) abandonos durante el período analizado. Ninguno ha abandonado el programa por ser expulsado y tan sólo 1 por ser encarcelado.

-31 sujetos (14\%) sin aceptar tratamiento.

3. En ARAD 4 sujetos (2\%).

4. En Proyecto Hombre 5 sujetos (2\%).

5. En Prisión 12 sujetos (5\%). En realidad son 13 pero uno está contabilizado como abandono.

En todo el período estudiado 30/6/93 a 30/6/94 se iniciaron en algún tipo de tratamiento 159 sujetos: 121 en metadona, 29 en naltrexona, 9 libre de drogas. Si se comparan con los 133 sujetos en tratamiento al finalizar el período es destacable la pérdida de 26 sujetos. Son:

-7 de Metadona: 3 alta médicas, 3 abandonos y 1 a ARAD.

-13 de Naltrexona: 1 alta médica y 12 abandonos.

-6 de Libre de Drogas: 2 altas médicas, 1 traslado y 3 abandonos.

\section{Comparación entre los grupos de Metadona, Naltrexona Y SIN TRATAMIENTO}

Este apartado pretende principalmente comprobar la eficacia relativa del programa de Metadona (114 sujetos) en comparación a Naltrexona (16 sujetos) y a «Sin Tratamiento» (67 sujetos). El resto de sujetos forman subgrupos muy pequeños: 3 en Libre de Drogas, 4 en ARAD, 5 en Proyecto Hombre y 13 en Prisión.

La descripción de los perfiles más característicos de los drogadictos inmersos en el programa de Metadona sobre todo en comparación con los de «Sin Tratamiento» es imprescindible no sólo desde la comprobación experimental de su influencia sobre los resultados que se puedan alcanzar (MARTIN, 1994. MELGAREJO y Cols., 1988) sino por su diferencialidad entre ellos y, por tanto, por sus efectos sobre el diseño de la comparación a efectuar.

El grupo de Metadona presenta un primer perfil muy importante como es la presencia en él de prácticamente todos los diagnosticados de SIDA así como prácticamente las tres cuartas partes de todos los policonsumistas. Este último dato es significativo por la comprobación (HUBBARD y Cols., 1988) de su peor respuesta al tratamiento.

Un segundo perfil corresponde a haber sido atendidos en tratamientos previos proporcionalmente en mayor medida que los «Sin Tratamiento». Hay una excepción en el caso de haber estado en comu- 
nidades terapeúticas. En este caso, sucede al revés y tiene su cierto grado de importancia porque casi un $60 \%$ de ellos han sido tratados en ellas.

Un tercer perfil corresponde directamente a los rasgos básicos de identificación: hay mayor proporción respecto a los de «Sin Tratamiento» de hombres, viviendo en Logroño, analfabetos o sin estudios (8 de cada 10), sin trabajo, casados y conviviendo con la propia familia o en pareja. Este conjunto de rasgos identificativos permite afirmar que en el programa de Metadona están una muy buena parte de lo que a lo largo del estudio se ha llamado el grupo de los «desfavorecidos», es decir, aquellos que sobresalen negativamente en los distintos aspectos analizados.

El grupo de «Sin Tratamiento» tiene también en primer lugar un perfil clave: acoge a los «dados de alta» (6) y a los trasladados (2) así como a los abandonos (29). Ninguna de las características de estos 37 sujetos están en programa de Metadona. De los 29 que han abandonado algún programa cabe decir que mayoritariamente han pasado por comunidad terapeútica.

El segundo perfil viene dado por los rasgos de identificación respecto al grupo de Metadona: hay proporcionalmente más mujeres, viviendo en Pueblos, solteros, viviendo con sus padres, con muy poca presencia relativa de los analfabetos o sin estudios y mucha más de los de estudios medios o superiores y con trabajo. En principio parecen constituir un grupo menos «desfavorecido» que el de Metadona pero es difícil aquilatar con objetividad hasta qué punto llegan las diferencias. En cualquier caso, tales diferencias sí son reconocibles y, por tanto, no al menos estadísticamente válido hablar de grupos homogéneos.

\section{A) Comparación Primaria entre los grupos}

En este apartado concreto se van a tomar para compararlos los resultados globales y «brutos» de los diferentes grupos a la fecha de la terminación del estudio (30 de junio de 1994) sin atender a sus respectivas peculiaridades que, quizás desde el inicio, los hagan diferentes e incluso incomparables.

La comparación entre el grupo de Metadona y el de Sin Tratamiento respecto a los distintos temas permite las siguientes conclusiones:

1. Un consumo proporcionalmente mayor de heroína y cocaína en el último mes por parte del grupo de Metadona y una administración por vena también proporcionalmente mayor. 


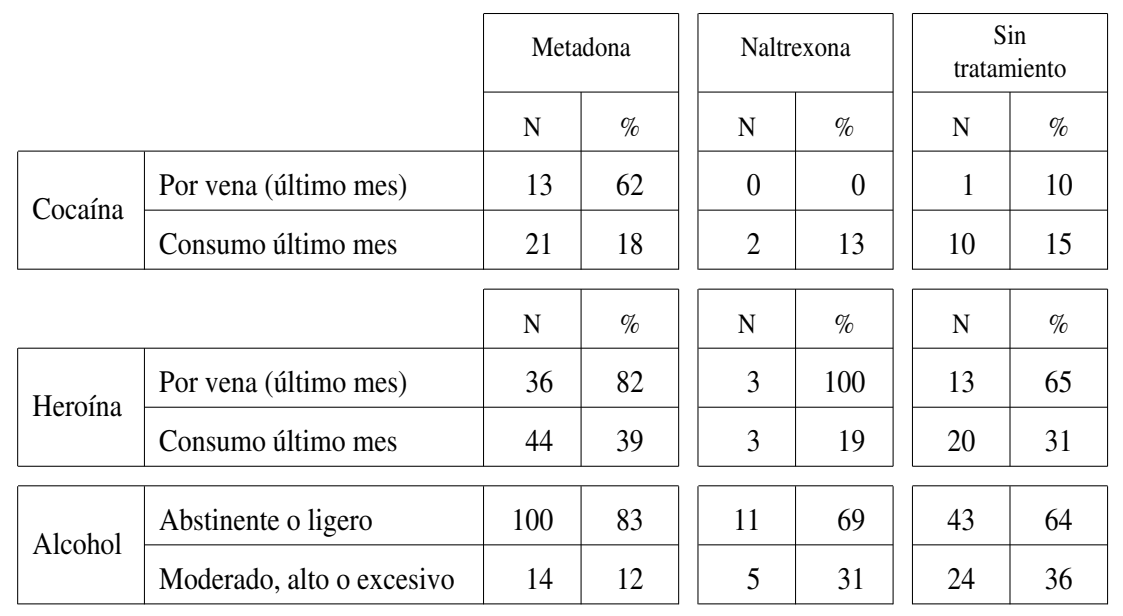

2. El descenso en el consumo de drogas es bastante similar en uno y otro grupo, sobre todo en heroína y cocaína. De consumir casi la totalidad descienden significativamente a consumir en el último mes hasta unos porcentajes en torno al $15 \%$.

3. En el consumo de alcohol, es notablemente menor entre los que siguen el programa de Metadona con un porcentaje de abstemios y bebedores ligeros del $83 \%$, bajando hasta el $64 \%$ para el grupo de los Sin Tratamiento.

4. En los hábitos de riesgo hay diferencias en una y otra dirección. Los de Metadona utilizan proporcionalmente mucho más la jeringa en razón a su mayor consumo de heroína respecto a los que están Sin Tratamiento y también tienden a reutilizarla en mayor medida. Sin embargo, en el hábito de utilizar una nueva cada vez el porcentaje es mayor que en el grupo de Sin Tratamiento. En el uso de preservativos los de Metadona practican más el usarlo siempre.

5. Respecto al ajuste social hay una mejoría entre los que se encuentran en el programa de Metadona: en los últimos tres meses el porcentaje de los que han pasado a disposición judicial entre los de Metadona es sensiblemente inferior a los que están Sin Tratamiento: ha estado ante el juez el 10\% de los de Metadona frente al $21 \%$ de los que están Sin Tratamiento.

6. En lo referente al estado de salud psicopatológico las diferencias son ligeramente favorables a los de Metadona que presentan un 3\% menos de porcentaje de «posibles casos psicopatológicos» que los que están Sin Tratamiento. 
7. En el apartado de estado de salud orgánico no hay comparabilidad por la gran ausencia de datos, en razón a la falta de contacto con el personal técnico de la Unidad, del grupo de Sin Tratamiento.

B) La Comparación entre los grupos «homogeneizados»

Las comparaciones realizadas en el apartado anterior entre los grupos sobre todo de Metadona y Sin Tratamiento dan finalmente como conclusión una relativa eficacia del tratamiento de Metadona en algunos aspectos como ajuste social, menor consumo de alcohol, hábitos de eliminación de riesgos de contagio, temáticas preventivas y un ligero mejor estado de salud psicopatológico, conclusiones similares a AMODIA, 1992 entre drogadictos también de Asturias.

Pero la comparación no es del todo válida porque los dos grupos no son homogéneos. Para homogeneizarlos se ha operativizado en este estudio en base a la neutralización de aquellos rasgos más sobresalientes presentes en un grupo y no en el otro. En el grupo de Metadona no se han considerado los 2 diagnosticados de SIDA y también se han dejado de considerar los 14 policonsumistas de heroína y cocaína ( 2 de ellos con SIDA). Por otra parte, en el grupo de «Sin Tratamiento» no se consideran los 6 sujetos dados de alta, los 2 trasladados y los 5 policonsumistas. El total de sujetos a comparar en un grupo y en otro son: 76 en Metadona y 51 en Sin Tratamiento.

\begin{tabular}{|l|c|c|c|c|}
\cline { 2 - 5 } \multicolumn{1}{c|}{} & \multicolumn{2}{c|}{ METADONA } & \multicolumn{2}{c|}{ SIN TRATAMIENTO } \\
\cline { 2 - 5 } \multicolumn{1}{c|}{} & $\mathrm{N}$ & $\%$ & $\mathrm{~N}$ & $\%$ \\
\hline Heroína consumida en el último mes & 19 & 25 & 15 & 29 \\
\hline
\end{tabular}

Si antes el grupo entero de Metadona consumía heroína en un 39\% en el último mes ahora desciende hasta el $25 \%$ en este nuevo grupo, situándose por debajo del grupo de Sin Tratamiento que desciende del $32 \%$ al $29 \%$. Lo mismo ocurre de manera significativa en el consumo de cocaína, en el consumo de alcohol, en el ajuste social y en el estado de salud psicopatológico. Los análisis sobre la eficacia del tratamiento de Metadona pasan a ser más positivos (SIMPSON, 1984) y cambian de dirección. El problema de fondo radica en conocer exactamente las características de la clientela a atender y los puntos fuertes de la programación y funcionamiento del propio programa, tema éste que en el 
presente estudio no se ha realizado pero al que se reconoce una decisiva importancia como elemento predictor de los resultados.

Se comprueba también estadísticamente la influencia relativa del tiempo de retención en el programa (a más tiempo retenido mejores resultados: de consumir en un $39 \%$ pasa al $30 \%$ tomando como colectivo a los que llevan más de 180 días de retención, incluyendo dentro del grupo a los diagnosticados de SIDA y a los policonsumistas) así como la fuerte incidencia de la categoría cultural «analfabetos», en este caso en sentido negativo. En ambos planteamientos bajo la perspectiva de la homogeneinización queda comprobada la mayor eficacia del programa de Metadona, siempre entendida respecto al grupo de Sin Tratamiento y no respecto a baremos preestablecidos fijados sobre «lo que debería ser».

\subsection{Hábitos de Riesgo}

1. UTILIZACIÓN DE JERINGA (AGUJA Y ÉMBOLO) EN LOS ÚLTIMOS SEIS MESES

-De los 211 sujetos que responden a esta pregunta, el 34,1\% (72 sujetos) afirma no haber utilizado jeringa en los últimos 6 meses.

—De los que dicen haberla utilizado (139 sujetos):

- El 36\% (50 sujetos) utiliza una nueva cada vez.

- El 64\% (89 sujetos) no utiliza una nueva cada vez, es decir las reutiliza sea por él mismo o después de usada por la pareja o amigos. Son muy pocos los que reutilizan la de desconocidos y tan sólo en un caso se afirma haberla alquilado.

-Atendiendo a este último subgrupo que reutiliza varias veces una misma jeringa, debe decirse que emplean distintos métodos para lavarla según sea el caso:

- De entre los que reutilizan su propia jeringa (86 sujetos), el $70 \%$ la lava con agua y el $30 \%$ con lejía u otros desinfectantes.

- De entre los que reutilizan la jeringa de la pareja o amigos (27), el 50\% la lava con agua y el otro 50\% la lava con lejía u otros desinfectantes.

- De entre los que reutilizan jeringas de desconocidos (6), 4 la lavan con agua, 1 con lejía y 1 no la lava.

Un hábito absolutamente arriesgado como pudiera ser compartir la jeringa con la pareja o amigos, o incluso con desconocidos parece des- 
cartado porque las cifras son 26 y 7 sujetos respectivamente sobre los 211 entrevistados. Por otra parte, siempre la limpian aunque no preferentemente con lejía sino con agua, sobre todo en el caso de los 7 sujetos que reutilizan la jeringa de desconocidos.

La influencia de la propaganda preventiva más la comunicación directa entre los propios drogadictos acerca de los peligros inherentes en el mal uso de la jeringa pueden ser las principales razones para encontrar un buen cuadro comportamental y un relativo escaso riesgo de contagio.

En el grupo, sin embargo, de los seroprevalentes al VIH que reutilizan de una u otra manera la jeringa hay una tendencia a mejorar. Se trata de su mayoritaria costumbre de lavarla sólo con agua. Los no seroprevalentes parecen tener una mejor costumbre de lavarla con lejía u otros desinfectantes.

\section{UTILIZACIÓN DE PRESERVATIVOS EN LAS RELACIONES SEXUALES}

—Relaciones sexuales vagina-pene: el 82,6\% de los 218 sujetos que responden a la pregunta dicen tenerlas.

-De ellos:

- el 34,6\% (64 sujetos) utiliza siempre preservativo.

- el 64,4\% (116 sujetos) no lo utiliza siempre.

-Relaciones sexuales vagina-pene durante la menstruación: el $73,6 \%$ (162 sujetos) dice no mantenerlas. Entre quienes las mantienen 33 sujetos no utilizan preservativos y 14 sí.

-Relaciones sexuales ano-pene: el 86,5\% (190 sujetos) no mantiene este tipo de relaciones. Entre quienes las mantienen 19 sujetos no utilizan preservativos y 3 sí.

Los datos producen cierta alarma por la posibilidad real de producir contagios múltiples y transmitir enfermedades infecciosas de consecuencias graves. A diferencia del uso de las jeringas donde parecen encontrarse unas prácticas más acordes con la disminución del riesgo, en el asunto de los preservativos no se manifiesta tanto interés o de hecho no se ha generalizado la práctica del preservativo como método apropiado para unas relaciones sexuales menos problemáticas. No se trata quizás de menor inculcación propagandística sobre los cuidados y precauciones que han de tomarse en las relaciones sexuales sino de un tema más íntimo y en parte todavía tabú donde son dos los actores a tomar la decisión. 
En este caso, los seroprevalentes al VIH utilizan siempre más los preservativos que los que no lo son. Parecen creer más en los riesgos de contagio por las relaciones sexuales que no por la reutilización de jeringas.

\subsection{Ajuste social}

1. El 77,6\% (172 sujetos) ha sido detenido alguna vez en su vida por la policía.

-De ellos, la gran mayoría 87,2\% (150 sujetos) han sido enviados ante el juez en un promedio de 6,10 veces.

- Las sentencias del juez se pueden dividir en:

- el 72,7\% (109) han sido sentencias de cárcel. El promedio de meses pasados en la cárcel asciende a 24,3 meses, es decir prácticamente 2 años. La variabilidad es, de todas formas, muy alta: desde 1 o 2 meses hasta 9 años.

- el 27,3\% (41) han tenido otro tipo de sentencias.

—El 22,4\% (50 sujetos) no ha sido detenido nunca.

2. En los últimos 3 meses:

-El 10,4\% (23) han sido detenidos. El promedio de veces detenido es de 1,65 veces.

-El 10,8\% (24) han tenido sentencia del juez.

3. En el momento de la entrevista:

-El 55,8\% (122 sujetos) están sin status limitador de libertad.

-El 18,9\% (42 sujetos) están en libertad provisional.

-El 9,9\% (22 sujetos) están en libertad condicional.

-El resto tienen otras circunstancias. Se sabe que son 17 personas las que están actualmente en la cárcel sobre el colectivo total de los 406 drogodependientes.

Coincidiendo con otros estudios (SANCHEZ CARBONELL, 1989) puede afirmarse el descenso proporcional de detenciones y encarcelamientos en el momento de la entrevista respecto a la situación un año antes. Lo mismo cabe decir en relación con la menor incidencia de problemas legales en las mujeres (MARTINEZ y Cols., 1987) tanto en el pasado como en el momento actual.

Existe una fuerte asociación entre haber tenido tratamientos previos y el ajuste social. Los que en mayor proporción han sido tratados en la red asistencial también presentan una mayor proporción de haber 
sido detenidos, juzgados, etc. El 91\%, por ejemplo, de los atendidos en urgencias por sobredosis ha sido a su vez detenidos alguna vez. Como si un modo de vida límite tuviera incidencia tanto en necesitar o pedir atención y en ser requerido por la justicia por su conducta desviada.

En similar dirección debería interpretarse la relación entre ajuste social y estado de salud orgánico. Un peor estado de salud (VIH, SIDA, Hepatitis) se correlaciona con un peor ajuste social. Un $81,5 \%$, por ejemplo, de los que padecen Hepatitis han sido detenidos en alguna ocasión.

\subsection{Estado de Salud Psicopatológico}

El GHQ28 es un cuestionario de 28 preguntas dirigido a la descripción del estado de salud mental del sujeto. Procede de un cuestionario mucho más amplio (GOLBERG, 1978) finalmente reducido y compuesto por 4 subescalas capaces de medir las siguientes áreas:

-Subescala A: (Preg. 1 a la 7): síntomas somáticos de origen psicológico.

- Subescala B: (Preg. 8 a la 14): síntomas de ansiedad.

- Subescala C: (Preg. 15 a la 21): síntomas relacionados con la disfunción social.

—Subescala D: (Preg. 22 a la 28): síntomas de «depresión severa».

La fiabilidad estadística del conjunto del cuestionario es $\mathrm{R}=0,92$ calculado por el método de la fórmula N. ${ }^{\circ} 20$ de Kuder-Richardson. La fiabilidad de las subescalas, calculada por el mismo método, es respectivamente: Subesc. A $=0,76$, Subesc. $B=0,85$, Subesc. $\mathrm{C}=0,84$ y Subesc. $\mathrm{D}=0,87$. Se trata, por tanto, de un instrumento de medición significativamente muy válido y fiable tanto en su conjunto como por sus cuatro subescalas.

La interpretación de los resultados de este cuestionario se basa en la puntuación alcanzada por cada sujeto. Como cada pregunta se puntúa con un $0=$ No síntoma o con un $1=$ Sí síntoma, la puntuación final ofrece el grado de psicopatología existente. Normalmente, se entiende como «posible caso psicopatológico» a aquél con una puntuación igual o superior a 5 puntos. Por contra, una puntuación inferior a 5 puntos se considera «posible no caso psicopatológico».

Los resultados más primarios indican la presencia de un colectivo con más de la mitad de los sujetos en situación psíquica posiblemente patológica. 
-El 41,9\% (93 sujetos) de los entrevistados son posibles no casos psicopatológicos, mientras el 58,1\% (129 sujetos) son posibles casos.

- La puntuación promedio alcanza los 8,89 puntos y la amplitud entre las puntuaciones va desde 0 hasta los 28 puntos, es decir, hay sujetos con síntomas psicopatológicos en los 28 aspectos investigados.

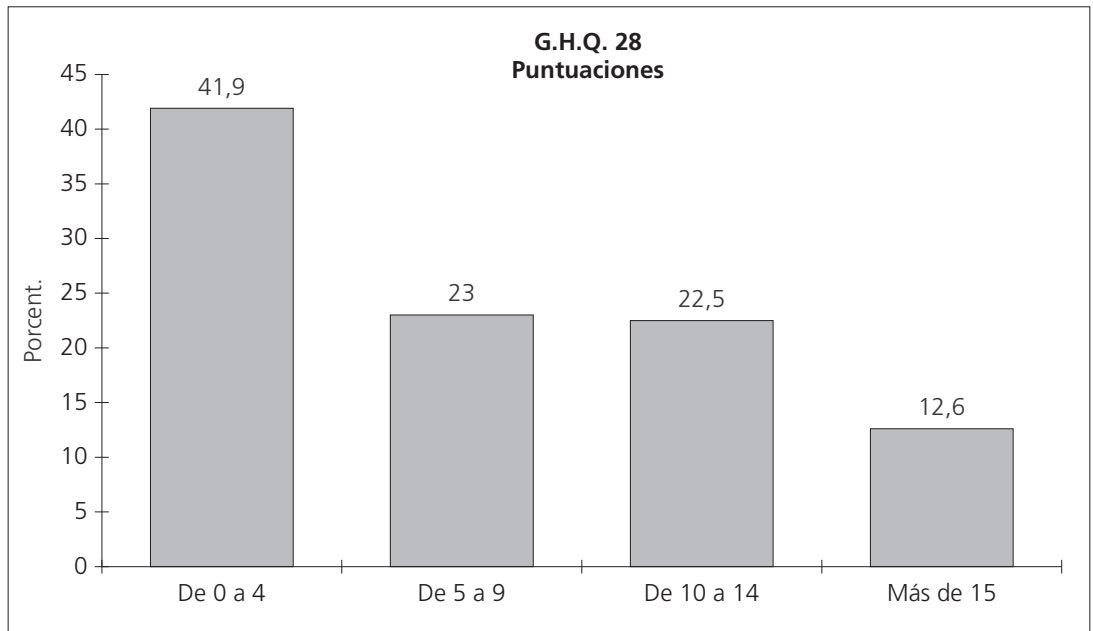

\begin{tabular}{|c|c|}
\hline SUBESCALA & $\begin{array}{c}\text { N.o sujetos } \\
\text { con } 5 \text { o más } \\
\text { puntos }\end{array}$ \\
\hline A & 27 \\
\hline B & 62 \\
\hline C & 23 \\
\hline D & 25 \\
\hline
\end{tabular}

Comparando los datos del gráfico anterior con los resultados de otros estudios (IGLESIAS, 1992. VAZQUEZ-BARQUERO y Cols., 1990. PINILLA Y SALCEDO, 1987. SWIFT y Cols., 1990. OTERO, 1991 , etc.) puede confirmarse que los resultados de nuestro estudio se colocan entre los más altos aunque sin llegar por ejemplo al $66 \%$ de posibles casos psicopatológicos encontrado por OTERO o al promedio 9,87 hallado por MARINA.

En cualquier caso, los datos expuestos parecen dejar sustentada una tesis: el equilibrio personal físico, psíquico, social y mental de los dro- 
gadictos es altamente endeble y resquebrajado. Es un conjunto de autopercepciones y sensaciones negativas y de baja autoestima llegando a plantearse la posibilidad de «quitarse de en medio». Naturalmente, no en todos, pero la puntuación media llega a 8,89 puntos y casi un $60 \%$ de ellos alcanza una puntuación de 5 o más puntos.

El cuadro de las subescalas, por otra parte, aclara el área donde más tendencia patológica existe. Es en la subescala B, la de ansiedad, medida en base a notarse agobiado, tener dificultades para dormir, sentir los nervios a flor de piel, asustarse y tener pánico, etc.

En el resto de las subescalas hay prácticamente el mismo número de posibles casos psicopatológicos. Llama la atención, no obstante, la escala D, midiendo aspectos fuertes como sentir que la vida no merece la pena vivirse, pensar en la posibilidad de quitarse de en medio, desear estar muerto y lejos de todo, venirle a la cabeza repetidamente la idea de quitarse la vida, etc. Los 25 sujetos con puntuación igual o mayor que 5 son un grupo muy numeroso si se recuerda la presencia importante de drogadictos de raza gitana para los cuales la idea del suicidio preguntada de una u otra manera no sólo les parece ridícula sino contraria a sus valores más profundos y ancestrales.

Todo este análisis conduce a una mayor comprensión acerca de la atmósfera existencial de los adictos a la heroína y de los porqués de sus conductas, de sus comportamientos y del poco éxito en la determinación de su autorehabilitación. Desde otra perspectiva, se fundamenta el necesario apoyo y ayuda personal e institucional para lograr muy poco a poco el restablecimiento de un cierto modus vivendi estable, pautado y de normalizada ciudadanía.

El cuadro siguiente recoge los porcentajes de los sujetos con respuesta afirmativa en cada pregunta de las cuatro subescalas.

\begin{tabular}{|c|c|c|c|c|}
\hline N. ${ }^{\circ}$ de Item & Subescala $« \mathrm{~A} »$ & Subescala $«$ B & Subescala «C» & Subescala «D» \\
\hline 1 & $23,42 \%$ & $46,40 \%$ & $16,22 \%$ & $14,86 \%$ \\
\hline 2 & $34,68 \%$ & $43,24 \%$ & $24,77 \%$ & $23,42 \%$ \\
\hline 3 & $36,04 \%$ & $45,05 \%$ & $16,22 \%$ & $22,97 \%$ \\
\hline 4 & $28,38 \%$ & $42,79 \%$ & $18,47 \%$ & $15,32 \%$ \\
\hline 5 & $4,95 \%$ & $15,77 \%$ & $24,77 \%$ & $23,42 \%$ \\
\hline 6 & $18,47 \%$ & $43,24 \%$ & $14,41 \%$ & $17,12 \%$ \\
\hline 7 & $36,94 \%$ & $31,98 \%$ & $22,52 \%$ & $13,51 \%$ \\
\hline
\end{tabular}


Si se lee con detenimiento el contenido de las 28 preguntas del cuestionario GHQ28 (Cfr. Anexo I) resultan muy ilustrativos los datos de la tabla por cuanto se tiene noticia exacta de aquellas preguntas con mayor índice de «sí», concretamente las de la Subescala B, la de ansiedad, mientras el resto de subescalas presentan porcentajes mucho más bajos. Se puede repensar, por ejemplo, el 17,12\% (pregunta 6 de la Subescala D) respondiendo sí a «¿Ha notado que desea estar muerto y lejos de todo?» o el 4,95\% (pregunta 5 de la Subescala A) «¿Ha tenido sensación de opresión en la cabeza o de que la cabeza le va a estallar?» o el 46,40\% (pregunta 1 de la Subescala B) « ¿Sus preocupaciones le han hecho perder mucho sueño?», etc. El análisis exhaustivo y detallado de todas las preguntas no es objeto de esta investigación pero el exponerlo aquí tiene la finalidad, quizás para investigaciones o estudios posteriores, de servir de guía para aquilatar alguna afirmación específica relacionada directamente con alguna o algunas preguntas concretas.

a) Relación con los Rasgos Básicos de Identificación

\begin{tabular}{|c|c|c|}
\hline & \multicolumn{2}{|c|}{$\begin{array}{c}\text { Posible caso } \\
\text { psicopatológico } \\
\text { según el test GHQ28 }\end{array}$} \\
\hline & $\mathrm{N}$ & $\%$ \\
\hline Hombre & 105 & 57 \\
\hline Mujer & 24 & 65 \\
\hline Menores de 25 años & 38 & 59 \\
\hline Entre 26-30 años & 43 & 57 \\
\hline Entre $31-35$ años & 29 & 54 \\
\hline Más de 36 años & 19 & 63 \\
\hline Soltero & 89 & 62 \\
\hline Casado & 56 & 44 \\
\hline Otros & 19 & 60 \\
\hline Viven en Logroño & 91 & 65 \\
\hline Viven en Pueblos & 38 & 46 \\
\hline
\end{tabular}




\begin{tabular}{|l|c|c|}
\cline { 2 - 3 } \multicolumn{1}{c|}{} & \multicolumn{2}{c|}{$\begin{array}{c}\text { Posible caso } \\
\text { psicopatológico } \\
\text { según el test GHQ28 }\end{array}$} \\
\cline { 2 - 3 } \multicolumn{1}{c|}{} & N & $\%$ \\
\hline Viven con sus padres & 69 & 58 \\
\hline Viven con familia propia & 33 & 55 \\
\hline Analfabetos y «sin estudios» & 39 & 62 \\
\hline Estudios primarios & 67 & 56 \\
\hline Medios o superiores & 81 & 57 \\
\hline Con trabajo & 52 & 46 \\
\hline Sin trabajo & 77 & 72 \\
\hline
\end{tabular}

Los resultados de la tabla sobre el estado de salud psicopatológico en función de ciertos rasgos de identificación tienen la importancia de fortalecer lo ya casi demostrado en distintos análisis anteriores, en este caso con la aparición de las mujeres. Llama la atención los relativamente abultados porcentajes de sujetos sin equilibrio personal ni psíquico sea por sintomatología somática, sea por excesiva ansiedad, sea por disfunción social o sea por depresión severa en las mujeres, en los Sin Trabajo (confirmado también por GUARDIA y Cols., 1987), en los que viven en Logroño, en los Solteros, en los analfabetos o sin estudios $\mathrm{y}$ en los mayores de 36 años.

Naturalmente debe recordarse la fuerte influencia de casi todos estos rasgos de identificación a la hora sobre todo de seguir consumiendo heroína o cocaína en el último mes. Lo mismo pudiera decirse respecto a seguir administrándose la heroína por vena $\mathrm{y}$, en general, respecto a un estar en disposición de encontrar el camino y la guía para enderezar el rumbo vital, familiar, laboral y personal.

En el cuadro de la página siguiente se exponen otros datos corroborativos de la tesis sobre la incidencia de un mal estado psíquico con ansiedad y disfunción social, entre otros desequilibrios, sobre ciertos comportamientos y situaciones vitales.

Efectivamente, los posibles SI casos psicopatológicos no sólo han sido atendidos proporcionalmente en mayor medida que los posibles NO casos en urgencias por sobredosis, por síndrome de abstinencia, etc., sino también presentan un cuadro de ajuste social más deformado así como un mayor policonsumo de Heroína y Cocaína, lo mismo que 
una cierta relación con un estado de salud orgánico más deficiente. A veces puede cuestionarse si el deficiente estado de salud psíquica es el parámetro inicial que influye en otros comportamientos o son estos comportamientos en otras áreas los factores originantes de la formación paulatina de un estado anímico y psíquico descontrolador y casi nada estabilizante. En algunos casos, lo más real quizás pueda situarse en una influencia mutua y en suceder simultáneamente los acontecimientos sin saber con exactitud qué es causa de qué.

\begin{tabular}{|l|c|c|c|c|}
\cline { 2 - 5 } \multicolumn{1}{c|}{} & \multicolumn{2}{c|}{$\begin{array}{c}\text { Posible SI caso } \\
\text { Psicopatológico }\end{array}$} & \multicolumn{2}{c|}{$\begin{array}{c}\text { Posible NO caso } \\
\text { Psicopatológico }\end{array}$} \\
\cline { 2 - 5 } \multicolumn{1}{c|}{} & $\mathrm{N}$ & $\%$ & $\mathrm{~N}$ & $\%$ \\
\hline Atendido en Urgencias por Sobredosis & 35 & 27 & 18 & 19 \\
\hline $\begin{array}{l}\text { Atendido en Urgencias por Síndrome de } \\
\text { Abstinencia }\end{array}$ & 48 & 37 & 30 & 32 \\
\hline Detenido en los últimos tres meses & 19 & 15 & 4 & 4 \\
\hline Ante el juez en toda su vida & 36 & 28 & 14 & 15 \\
\hline Policonsumidor Heroína más Cocaína & 18 & 14 & 5 & 5 \\
\hline Seroprevalente al VIH & 43 & 45 & 29 & 31 \\
\hline Diagnosticado de SIDA & 19 & 15 & 10 & 11 \\
\hline
\end{tabular}

\subsection{Estado de Salud Orgánico}

\section{A) Seroprevalentes al VIH}

El índice de seroprevalencia al VIH alcanza el 41,1\% (72) de los 175 sujetos de los que se dispone información. De 61 casos de los que se conoce la fecha de seroprevalencia en 54 de ellos es anterior al 30 de junio de 1993.

Los porcentajes más altos se encuentran entre los mayores de 30 años $(60 \%)$ y entre los que viven en Logroño (47\%).

La influencia de un mayor consumo de drogas se verifica también en nuestro estudio como factor influyente en la seroprevalencia (LOPEZ ABENTE y Cols., 1988. DE LA FUENTE y Cols., 1991) así como, en buena lógica, los que han utilizado o utilizan la vía intravenosa para administrarse la heroína y la cocaína son los que mayores proporciones de seroprevalencia al VIH presentan. Junto a ellos, los hábitos de ries- 
go en el uso de la jeringuilla también dejan clara su influencia: 20 sujetos reutilizan la jeringa que otros usan. 10 la lavan con agua y 9 son seroprevalentes. De los otros 10 que la limpian con lejía u otros desinfectantes, tan «sólo» 2 son seroprevalentes al VIH.

\section{B) Diagnoticados de SIDA}

29 personas han desarrollado la enfermedad según la muestra. Esto supone el 18\% de los datos válidos (sobre 161 sujetos de los que se tienen datos).

La descripción de ese numéricamente escaso pero importante grupo de diagnosticados de SIDA comienza por la certificación de la presencia ya típica de ciertos rasgos básicos de identificación caracterizadores de lo que a lo largo del estudio se ha denominado el grupo de los «desfavorecidos»: hombres (25), de entre 23 y 26 años (21), viviendo en Logroño (19), solteros (18), viviendo con sus padres (18), «sin estudios» (25) y sin trabajo (19).

Todos han sido consumidores de heroína. En el último mes son 13, lo cual significa que han dejado de consumir 17. También todos menos uno han sido consumidores de cocaína. En el último mes tan sólo son 3 , por lo que 25 han dejado de consumirla.

Se puede afirmar la inexistencia de relación con el alcohol entre los diagnosticados de SIDA.

Su ajuste social ha sido en cierto modo crítico: prácticamente todos han sido detenidos alguna vez (26), más de la mitad (16) han estado más de un mes en la cárcel y también más de la mitad (17) tienen en la actualidad causas pendientes con la justicia. En los últimos tres meses, sin embargo, parecen huir de situaciones delictivas al no destacar por detenciones, ni por presencias ante el juez.

Es muy alta la influencia del estado de salud orgánico sobre el estado de salud psicopatológico. De hecho, de los 29 diagnosticados de SIDA 19 presentan un cuadro de posible caso psicopatológico (5 o más puntos en el test GHQ28) destacando el nivel alto de ansiedad.

Casi todos ellos (26) están atendidos en el programa de Metadona y 2 lo están en el programa de Naltrexona.

Los hábitos de riesgo no son especialmente tranquilizadores: 17 no usan siempre preservativos en sus relaciones sexuales vagina-pene y cuando consumían heroína 24 lo hacía por vena. De los 13 consumidores de heroína en el último mes 11 lo hacen por vena.

La gran mayoría ha sido admitido varias veces en tratamientos previos sean los servicios ambulatorios, la unidad de desintoxicación, 
los programas de metadona, las urgencias por sobredosis o por síndrome de abstinencia, etc.

\section{C) Hepatitis}

De los 161 sujetos de los que se dispone de esta información el $77,0 \%$ (124) han sufrido hepatitis.

La influencia del consumo de drogas sobre la hepatitis, al igual que en el caso del VIH, es relevante sobre todo en función de las vías de administración de la heroína y la cocaína. Así de los 54 consumidores de heroína administrada por vena en la actualidad (últimos seis meses) el 91,8\% (50) han padecido hepatitis.

El haber sufrido hepatitis también está ligado con los tratamientos previos en toda su amplia gama, salvo en el caso de haber sido atendido en comunidades terapéuticas. Llama la atención que hayan sido el 90,6\% de los admitidos en programas de metadona y el $86,4 \%$ de los atendidos en urgencias en relación con el tema de drogas.

También en este caso presentan un desajuste social importante. De los detenidos alguna vez, el $82,1 \%$ (101) han padecido hepatitis y el 90,3\% (28) de los que han sido presentados ante el juez más de cinco veces. 


\section{Anexo I}

I. DATOS PERSONALES Y SOCIODEMOGRAFICOS

1. Sexo:

$$
\text { ..... Hombre ..... Mujer }
$$

2. ¿Cuál es su fecha de nacimiento? (Edad actual)

Día ..... Mes ......... . Año ..... Edad .....

3. ¿Cuál es el lugar de nacimiento? (Municipio y Provincia)

(Si es en el extranjero consignar país y nacionalidad/es)

4. ¿En qué lugar ha nacido su padre? (Municipio y Provincia)

5. ¿Cuál es su lugar habitual de residencia?

Fijo:

Variable:

6. ¿Cuál es su estado civil actual?

..... Soltero $\quad \ldots$. . . Casado ..... Viudo

7. En la actualidad está viviendo con...

.... Sus padres $\quad \ldots$. Familia propia $\ldots$. . En pareja

..... Solo .... Otros familiares

..... Con otras personas .... Otros

8. ¿Ha hecho el servicio militar?

..... Sí .... . No

9. (En caso de contestar que NO) ¿Por qué motivo no lo ha hecho?

No haber alcanzado la edad

. . . . Excedente de cupo

.... Hijo de viuda, manutención de hijos, etc.

. . . . Inútil por toxicomanía

. . . . Inútil por causas psíquicas

.... Inútil por causas físicas

..... Otras

(especificar: 
10. ¿Cuál es su nivel de estudios? (Se refiere a estudios finalizados) ..... Analfabeto

..... Sin estudios (sabe leer y escribir, pero no finalizó la enseñanza de primer grado)

..... Estudios primarios (EGB)

..... FP1, Bachiller elemental

.....FP2, Bachiller superior

..... Estudios superiores

..... Otros

11. En el tiempo transcurrido desde el contacto con CSM (Centro de Salud Mental), ha obtenido algún diploma, certificado o título?

$\ldots$.... No

..... Sí (Especificar.

12. En la actualidad, ¿está matriculado en algún centro escolar (Instituto, Universidad, etc., público o privado) o en algún centro de enseñanza profesional o artística?

..... No

. . . . Centro de enseñanza general básica (EGB)

.... . Centro de Bachillerato unificado Polivalente (BUP)

... . Universidad, Facultad, Escuela Universitaria, etc.

. . . . Enseñanza permanente de adultos

.... CENEBAD (EGB a distancia)

.... IMBAD (BUP a distancia)

.... . Centro Oficial de Formación Profesional

..... Centro oficial y/o colaborador de Formación Profesional (INEM)

..... Academias privadas acreditadas (AFA, CEA, MAYMO, etc.)

.... Otros (especificar. . . . . . . . . . . )

13. ¿Abandonó Vd. sus estudios?

..... No

..... Sí ¿A qué edad?....

14. ¿Cuántos años en total ha estado Vd. estudiando, es decir, escolarizado?

15. Antes del contacto con los Equipos de Atención de Drogodependencias ¿tenía Vd. trabajo remunerado? ..... Sí ..... No 
16. ¿Actualmente tiene Vd. alguna actividad o tarea ocupacional? . No ..... Sí

(Si se ha contestado SI): Cuál

(Especifique)

\section{CONSUMO DE DROGA}

17. ¿Cuál es tu comportamiento respecto al consumo de droga?

\begin{tabular}{|c|c|c|c|c|c|c|c|}
\hline $\begin{array}{l}\text { TIPO } \\
\text { DE } \\
\text { DROGA }\end{array}$ & $\begin{array}{c}\text { Consumida } \\
\text { alguna } \\
\text { vez SI }\end{array}$ & $\begin{array}{c}\text { Consumida } \\
\text { alguna } \\
\text { vez NO }\end{array}$ & $\begin{array}{c}\text { Edad } \\
\text { Primer } \\
\text { consumo }\end{array}$ & $\begin{array}{c}\text { Vía } \\
\text { entrada } \\
\text { actual }\end{array}$ & $\begin{array}{c}\text { Vía } \\
\text { entrada } \\
\text { pasado }\end{array}$ & $\begin{array}{c}\text { Consumo } \\
\text { en el último } \\
\text { mes }(*)\end{array}$ & $\begin{array}{c}\text { Orden } \\
\text { de } \\
\text { consumo } \\
(* *)\end{array}$ \\
\hline \multicolumn{8}{|l|}{ Alcohol } \\
\hline \multicolumn{8}{|l|}{$\begin{array}{l}\text { Cannabis } \\
\text { (Porros) }\end{array}$} \\
\hline \multicolumn{8}{|c|}{$\begin{array}{l}\text { Alucinógenos } \\
\text { (LSD, Acidos) }\end{array}$} \\
\hline \multicolumn{8}{|l|}{ Cocaína } \\
\hline \multicolumn{8}{|l|}{ Heroína } \\
\hline \multicolumn{8}{|c|}{ Tranquilizantes } \\
\hline \multicolumn{8}{|l|}{$\begin{array}{l}\text { Opiáceos } \\
\text { (Buprex) }\end{array}$} \\
\hline \multicolumn{8}{|l|}{ Anfetaminas } \\
\hline Pegamentos & & & & & & & \\
\hline
\end{tabular}

(*) Frecuencia de consumo de droga en el último mes:

$0 \mathrm{NS} / \mathrm{NC}$

1 Ninguno

2 Menos de una vez al mes

3 Entre 1 y 3 veces al mes

4 Una vez a la semana
5 Entre 2 y 3 veces por semana 6 Entre 4 y 6 veces por semana 7 Una vez al día

8 Entre 2 y 3 veces al día

94 o más veces al día

-Frecuencia de consumo de tabaco en el último mes

0 NS/NC. 1. Menos de 10 cigarrillos. 2. Entre 11 y 20. 3. Más de 1 paquete.

(**) Indicar el orden de cuál ha sido la droga $1 .^{a} 2 .^{a}$ y $3 .^{a}$ consumida. 
III. CONSUMO DE ALCOHOL

18. Habitualmente, ¿cuánto suele beber Vd. durante los días de la semana?

\begin{tabular}{|c|c|c|c|c|c|c|c|}
\hline & $\begin{array}{c}\text { Lunes } \\
\text { N. }{ }^{\circ} \text { vasos } \\
\text { o copas }\end{array}$ & $\begin{array}{c}\text { Martes } \\
\text { N. }{ }^{\circ} \text { vasos } \\
\text { o copas }\end{array}$ & $\begin{array}{c}\text { Miércoles } \\
\text { N. }{ }^{\circ} \text { vasos } \\
\text { o copas }\end{array}$ & $\begin{array}{l}\text { Jueves } \\
\text { N. }{ }^{\circ} \text { vasos } \\
\text { o copas }\end{array}$ & $\begin{array}{c}\text { Viernes } \\
\mathrm{N}^{\circ} \text { vasos } \\
\text { o copas }\end{array}$ & $\begin{array}{l}\text { Sábado } \\
\text { N. }{ }^{\circ} \text { vasos } \\
\text { o copas }\end{array}$ & $\begin{array}{l}\text { Domingo } \\
\text { N. }{ }^{\circ} \text { vasos } \\
\text { o copas }\end{array}$ \\
\hline \multicolumn{8}{|l|}{ Cerceza } \\
\hline \multicolumn{8}{|l|}{ Vino } \\
\hline \multicolumn{8}{|l|}{$\begin{array}{l}\text { Brandy- } \\
\text { Licores }\end{array}$} \\
\hline \multicolumn{8}{|l|}{$\begin{array}{l}\text { Aperitivos } \\
\text { (Jerez, } \\
\text { Vermut, etc.) }\end{array}$} \\
\hline \multicolumn{8}{|l|}{ Whisky } \\
\hline Combinados & & & & & & & \\
\hline
\end{tabular}

\section{HABITOS DE RIESGO}

19. En relación con el uso de jeringa (aguja y émbolo), indique aquellas prácticas que haya utilizado usualmente en los últimos seis meses.

¿Utiliza una jeringuilla nueva cada vez?: Sí. . . . . No. . . . . (Si la respuesta es NO, responda al siguiente cuadro):

\begin{tabular}{|l|l|l|l|}
\hline \multirow{2}{*}{ PROCEDENCIA } & \multicolumn{3}{|c|}{ PRACTICA } \\
\cline { 2 - 4 } & Lavado con agua & $\begin{array}{c}\text { Lavado con lejía, } \\
\text { alcohol, desinf. }\end{array}$ & $\begin{array}{c}\text { Otros } \\
\text { procedimientos }\end{array}$ \\
\hline Reutilizada por él mismo & & & \\
\hline $\begin{array}{l}\text { Reutilizada después de usada por } \\
\text { la pareja o amigos }\end{array}$ & & \\
\hline $\begin{array}{l}\text { Reutilizada después de usada por } \\
\text { desconocidos o encontrada en la calle }\end{array}$ & & & \\
\hline Alquilada después de usada por otros & & & \\
\hline
\end{tabular}


20. ¿Utiliza en sus relaciones sexuales alguna de las siguientes medidas?:

\begin{tabular}{|l|l|l|l|}
\cline { 2 - 4 } \multicolumn{1}{c|}{} & Siempre & A Veces & Nunca \\
\hline -Preservativo en las relaciones vagina-pene & & & \\
\hline -Preservativo en las relaciones vagina-pene durante la menstruación & & & \\
\hline -Preservativo en las relaciones ano-pene & & & \\
\hline - Evitar la eyaculación intravaginal, intrarectal o intrabucal & & & \\
\hline -Otros. Cuáles... & & & \\
\hline
\end{tabular}

(Si no se mantienen relaciones del tipo expuesto, dejar en blanco)

V. TRATAMIENTOS PREVIOS AL CONTACTO CON EL EQUIPO DE ATENCION DE DROGODEPENDENCIAS

21. Antes de entrar en contacto con el Equipo de Atención de Drogodependencias ¿cuántas veces ha sido admitido (tratado)?

\begin{tabular}{|l|l|}
\hline MODALIDAD DE TRATAMIENTO & NUMERO DE VECES \\
\hline Servicio ambulatorio & \\
\hline Comunidad Terapéutica & \\
\hline Unidad de Desintox. hospitalaria & \\
\hline Mantenimiento con Metadona & \\
\hline Otros. Cuál... & \\
\hline
\end{tabular}

22. ¿Ha sido atendido alguna vez en un servicio de urgencias debido a su consumo de drogas o a padecer un síndrome de abstinencia? ..... Sí . . . . No

23. ¿Cuántas veces le han atendido en urgencias por los siguientes motivos?

Por Sobredosis ..... veces

Por Síndrome de abstinencia ..... . veces

Por Patología orgánica asociada . . . . . veces 
VI. NIVEL DE AJUSTE SOCIAL

24. ¿Le ha detenido alguna vez la policía por motivos distintos de los políticos o sindicales?

..... Sí ..... No

25. ¿Cuántas de estas detenciones se han producido en los últimos tres meses? $\ldots$... veces

26. ¿Cuántas veces en su vida le ha enviado el juez a la cárcel o le ha dejado en libertad provisional o bajo fianza?

..... veces

27. ¿Cuántas veces, en los últimos tres meses se ha visto en la situación anterior?

..... veces

28. ¿Cuánto tiempo ha cumplido condena en la cárcel en toda su vida?

29. En el momento de realizar esta entrevista, ¿está en libertad provisional o condicional o tiene alguna limitación legal de su libertad?

.... Sin status legal limitador de libertad

..... Libertad provisional (en espera de juicio)

.... Libertad condicional (ha salido de prisión antes de cumplir toda su condena)

.... . Pase fin de semana u otro tipo de salida

..... Otros (especificar.

VII. ESTADO GENERAL DE SALUD

30. ¿Se ha sentido perfectamente bien de salud y en plena forma?

1. Mucho peor de lo habitual 3. Igual que lo habitual

2. Peor de lo habitual 4. Mejor de lo habitual

ATENCION: Forma de contestar a las siguientes preguntas.

1. No, en absoluto

2. No más que lo habitual

3. Bastante más que lo habitual

4. Mucho más que lo habitual 
Rodee con círculo el número de su contestación

31. ¿Ha tenido la sensación de que necesitaba un reconstituyente?

32. ¿Se ha sentido agotado y sin fuerzas para nada?

33. ¿Ha tenido la sensación de que estaba enfermo?

34. ¿Ha padecido dolores de cabeza?

35. ¿Ha tenido sensación de opresión en la cabeza o de que la cabeza le va a estallar?

36. ¿Ha tenido oleadas de calor o escalofríos?

37. ¿Sus preocupaciones le han hecho perder mucho sueño?

38. ¿Ha tenido dificultades para seguir durmiendo de un tirón toda la noche?

39. ¿Se ha notado constantemente agobiado y en tensión?

40. ¿Se ha sentido con los nervios a flor de piel $\mathbf{y}$ malhumorado?

41. ¿Se ha asustado o ha tenido pánico sin motivo?

42. ¿Ha tenido la sensación de que todo se le viene encima?

43. ¿Se ha notado nervioso y a punto de explotar constantemente?

\begin{tabular}{llll}
1 & 2 & 3 & 4 \\
1 & 2 & 3 & 4 \\
1 & 2 & 3 & 4 \\
1 & 2 & 3 & 4 \\
1 & 2 & 3 & 4 \\
1 & 2 & 3 & 4 \\
1 & 2 & 3 & 4 \\
1 & 2 & 3 & 4 \\
1 & 2 & 3 & 4 \\
1 & 2 & 3 & 4 \\
1 & 2 & 3 & 4 \\
1 & 2 & 3 & 4 \\
1 & 2 & 3 & 4 \\
\hline & & &
\end{tabular}

ATENCION: Rodee con un círculo el número de su respuesta

44. ¿Se las ha arreglado para mantenerse ocupado y activo?

1. Más activo que lo habitual

2. Igual que lo habitual

3. Menos que lo habitual

4. Mucho menos que lo habitual

45. ¿Le cuesta más tiempo hacer las cosas?

1. Más rápido que lo habitual

2. Igual que lo habitual

3. Más que lo habitual

4. Mucho más que lo habitual 
46. ¿Ha tenido la impresión en conjunto de que está haciendo las cosas bien?

1. Mejor que lo habitual

2. Aproximadamente lo mismo

3. Peor que lo habitual

4. Mucho peor que lo habitual

47. ¿Se ha sentido satisfecho con su manera de hacer las cosas?

1. Más satisfecho

2. Aproximadamente lo mismo

3. Menos que lo habitual

4. Mucho menos que lo habitual

48. ¿Ha sentido que está jugando un papel útil en la vida?

1. Más útil que lo habitual

2. Igual que lo habitual

3. Menos que lo habitual

4. Mucho menos que lo habitual

49. ¿Se ha sentido capaz de tomar decisiones?

1. Más que lo habitual

2. Igual que lo habitual

3. Menos que lo habitual

4. Mucho menos que lo habitual

50. ¿Ha sido capaz de disfrutar de sus actividades normales de cada día?

1. Más que lo habitual

2. Igual que lo habitual

3. Menos que lo habitual

4. Mucho menos que lo habitual

ATENCION: Forma de contestar a las siguientes preguntas

1. No, en absoluto

2. No más que lo habitual

3. Bastante más que lo habitual

4. Mucho más que lo habitual

Rodee con un círculo el número de su contestación

51. ¿Ha pensado que Ud. es una persona que no vale para nada?

52. ¿Ha venido viviendo la vida totalmente sin esperanzas?

\begin{tabular}{|llll}
\hline 1 & 2 & 3 & 4 \\
1 & 2 & 3 & 4 \\
\hline
\end{tabular}


53. ¿Ha tenido el sentimiento de que la vida no merece la pena vivirse?

54. ¿Ha pensado en la posibilidad de «quitarse de en medio»?

55. ¿Ha notado que a veces no puede hacer nada porque tiene los nervios desquiciados?

56. ¿Ha notado que desea estar muerto y lejos de todo?

57. ¿Ha notado que la idea de quitarse la vida viene repetidamente a la cabeza?

$\begin{array}{llll}1 & 2 & 3 & 4 \\ 1 & 2 & 3 & 4 \\ 1 & 2 & 3 & 4 \\ 1 & 2 & 3 & 4 \\ 1 & 2 & 3 & 4\end{array}$




\section{CUESTIONARIO DE ESTADO \\ DE SALUD ORGANICO}

1. ¿Tras el contacto con el equipo se acordó e inició realmente un tratamiento?

1. No, el profesional no lo consideró necesario

2. No, el paciente no aceptó o lo abandonó tras 1 o 2 entrevistas

3. Sí, realiza más de 3 consultas con el equipo en el intervalo de 1 mes

4. Sí, otras características

2. ¿Se realizó una valoración física adecuada?

1. Sí

2. No, no pudo completarse por .

3. El paciente es seroprevalente al VIH

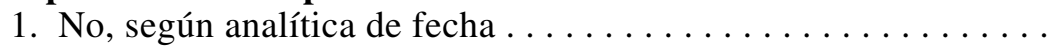

2. Sí, según analítica de fecha $\ldots \ldots \ldots \ldots \ldots \ldots \ldots \ldots \ldots$

3. No se dispone de ninguna analítica específica de este paciente

4. ¿El paciente está diagnosticado de SIDA?

1. SI

2. NO

5. ¿Ha sufrido hepatitis?

1. SI

2. NO

6. ¿Ha identificado cualquier otra patología física al inicio o durante el tratamiento?

¿Cuál? .

7. ¿Desintoxicación?

1. NO

2. Sí, Ambulatorio

3. Sí, Hospitalario Finalizó el mismo?: Sí .... No .....

8. Incorporado al Sub-Programa:

Fecha de Inicio Fecha finalización Causa

1. PM agonistas

Dosis media/día

2. PM antagonistas $\ldots . / \ldots / \ldots . \ldots / \ldots / \ldots \ldots \ldots \ldots$

3. P. Libre de Drogas. . . . . . . . . . . . . . . . . . . 
9. Porcentaje de orinas sucias sobre las realizadas durante el último mes del tratamiento:

10. Fecha de la última analítica de orina realizada $\ldots \ldots / \ldots / \ldots$ Resultado:

11. Tiempo en tratamineto hasta el día de la fecha o hasta su finalización. (Se consideran los días transcurridos desde que inició el último tratamiento y teniendo en cuenta que haya mantenido contactos con cualquier dispositivo de la red con un intervalo entre contactos no mayor de 30 días): .... . días.

\section{Situación actual}

1. Continúa en tratamiento a la fecha: . . . . . . . . . .

2. Alta médica por consecución de los objetivos marcados (con o sin derivación a un centro no específico) Fecha: . . . . . . . . . . .

3. Trasladado a ...........

4. Abandono a iniciativa del paciente. Fecha: . . . . . . . . . .

5. Encarcelado. Fecha: ..............

6. Expulsión. Fecha: . . . . . . . / . . .

7. Otros ............ 


\section{Bibliografía}

AIKEN, L.S.: «Retrospective self-reports by clients differ from original reports: Implications for the evaluation of drug treatment programs» The international journal of the addictions, 21 (7) 767-788. 1986.

AMERICAN PSYCHIATRIC AsSOCIATION: Diagnostic criteria from DSM- III-R. Washington: APA. 1987.

AmodiA, R: Epidemiología de las toxicomanías en la red de salud mental de Asturias (1986-1989). Servicio de Publicaciones del Principado de Asturias. Oviedo. 1992.

IgLESIAS, C.A.: Salud mental y atención primaria, un análisis epidemiológico. Tesis Doctoral. Facultad de Medicina. Universidad de Cantabria. 1992.

BALE, R.N., CABRERA, S., BRown, J.: «Follow up evaluation of drug treatment» Amerian Journal drug alcohol abuse, 4, 233-246. 1977.

BENSON, G.: "Course and outcome of drug abuse and medical and social conditions in selected youngs drug abusers». Acta psichiatr. Scand., 71, 46-66. 1985.

Comas, D., Carrón, J., Hernández, M.I., Nieva, P., Silva, A.: Los estudios de seguimiento. Una experiencia metodológica. Caracas: Fundamentos. 1992.

Comas, D.: Uso de droga: del paradigma lewiniano al nuevo rol de las expectativas simbólicas. Jano, 713, pp. 64-81, 1986.

Corty, E., Ball, J.C., Myers, C.P.: «Psychologycal symptoms in methadone maintenance patiens: Prevalence and C. over treatment». Journal of Con. and Clin. Psy. 56, (5), 776-777. 1988.

Cotrrell, D., Childs-Clarke, A., Ghodse, A.H.: «British opiate addicts: an 11 year follow-up». British Journal of Psychiatry, 146, pp. 448-450, 1985.

CRADDOCK, S.G., BrAY, R.M., HubBARD, R.L.: «Drug use before and during drug abuse treatment: 1979-1981 TOPS admision cohorts». Research institute for the natinal institute on drug abuse, $\mathrm{N}^{\circ}$ de la publicación (ADM) 85-1.387, Rockville, U.S.A. 1985.

De León, G., Schwartz, S.: «Therapeutic communities: What are the retention ratesz». Amerian Journal drug and alcohol abuse, 10 (2), 167-284. 1984.

Dole, V.P., JosePH, H.: «Long-term outcome of patients treated with methadone maintenance». Annals of the New York Academy of sciences, 311, 181. 1978.

FuENTE DE LA L., LÓPEZ, R., BRAVO, M.J.: «Infección por VIH en usuarios de drogas». Ministerio de Sanidad y Consumo. Delegación del Gobierno para el Plan Nacional de Drogas, Madrid, 1991.

GARCÍA MARTín, E.: «Estudio longitudinal retrospectivo de 166 drogodependientes que recibieron tratamiento en el programa de comunidad terapéutica de "Haize-Gain" entre los años 1982-1992». Trabajo Fin Master en Drogodependencias. Universidad de Deusto. 1994.

GolDBERG, D.: «Manual of the General Health Questionaire». National Foundation for Education Research. Windsor, 1978.

GEARING, F.R., THOMPSON, F.: «What's good about methadone maintenance after ten years?» Proceedings of second National Drug abuse conference, inc. New Orleans, (Drug abuse-Modern Trends, issues and perspectives, 645-666. 1975. 
GREIF, G.L., PoremBSKI, E.: «Significant others of I.V. drug abusers with AIDS: New challenges for drug treatment program». Journal of substance abuse treatment, 4, 151-155. 1987.

GRUPO INTERDISCIPLINAR SOBRE DROGAS: «Los estudios de seguimiento (un año) de adictos a la heroína». Revista de Psiquiatría de la Facultad de Medicina de Barcelona, 10, pp. 357-381, 1983.

GuARDiA, J., GonZÁLEZ, S.: «Estudio de seguimiento (un año) de adictos a la heroína». Revista de Psiquiatría de la Facultad de Medicina de la Universidad de Barcelona. (10), 357-381.

Guardia, J., Masip, J., Viladrich, C.: «Estudio de seguimiento de adictos a la heroína a los tres años de su admisión a tratamiento». Comunidad y drogas. 3 , 61-79. 1987.

Hubbard, R.L., Rachal, J.V., Graddock, J.G., Cavanugh, E.R.: «Treatment Outcome Prospectives Study (TOPS): Client characteristics and behaviors before, during and after treatment». In. F.M. Tims, J.P. LUDFORD (Eds.), Drug abuse treatment evaluation: strategies, progress and prospects. 42-68. National Institute on Drug Abuse. Research monograph 51. DHHS publ. ADM 841.329. 1984.

JAFFE, J.: «Evaluating drug abuse treatment» en Drug abuse treatment evaluation: strategies, progress and prospects. Tims, F. LudFORD, J. de Research Monograph Series, pp. 13-28. NIDA. Mariland, 1984.

Joe, G., Singh, B., Lehman, W., Simpson, D., Sells, S.: «Agency differences in post-treatment outcomes: a follow-up of drug abuse treatment clients». The international journal of the addictions, 18, 523-538. 1983.

Joe, G.W., Person, P.JR., Sells, S.B., RetKA, R.L.: «An evaluative study of methadone and drug free therapies for opiate addiction». IBR report n. ${ }^{\circ} 72,14$ S.B. Sells (Ed.). Evaluation of treatment. Ballinger press, Cambridge. Massachusetts. 1972.

JoE, G.W.: «Studies of retention in treatment of drug users in the DARP: 19691971 admisions». S.B. Sells (Ed.). Evaluation of treatment. Vol. 1, Chap 18. Ballinger press, Cambridge. Massachusetts. 1976.

Kosten, T.R., Rounsaville, B.J.: «Psychopathology in opioid addicts». Psychiatric clinics of north america. 9 (3), 515-532. 1976.

Kosten, T.A., Kosten, R.T., Rounsaville, B.J.: «Personality disorders in opiate addicts show prognostics specifity». Journal of substance abuse treatment. 6 , 163-168. 1989.

Kosten T.R., Jalali, B., Hogan, I.K., Klever, H.D.: «Family denial as a prognostic factor in opiate addict treatment outcome». The journal of N. and mental disease. 171 (10), 611-616. 1983.

Kosten, T.R., Rounsaville, B.J., Klever, H.D.: «A 2.5-year follow-up depression, life crises and treatment effects on abstinence among opioid addicts». Archieves General of psychiatry. 43, 733-738. 1986

Kosten, T.R., Rounsaville, B.J., Klever, H.D.: «Multidimensionality and prediction of treatment outcome in opioid addicts: 2.5-year follow-up». Comprehensive psychiatry. 28 (1), 112-119. 1987. 
Laporte, D.J., Maclellan, A.T., Erdlen, F.R., Parente, R.J.: «Treatment outcome as a function of follow-up difficulty in substance abusers». Journal of consulting and clinical psychology. 49 (1), 112-119. 1980.

López Abente, G., Monge, V., Rubio, G., Pascual, J.: «Factores de riesgo en la transmisión del virus de la inmunodeficiencia humana en adictos a drogas por vía parenteral». Medicina Clínica, 90, pp. 769-771, 1988.

MaClellan, A.T., Luborsky, L., Woody, G.E., O’Brien, C.P.: «An improved diagnostic evaluation instrument for substance abusers patient. The addiction severity index». The journal of nervous and mental disease. 168, 26-33. 1980.

Maclellan, A.T., Luborsky, O’Brien, C.P., Barr, H.L., Evans, F.: «Alcohol and drug abuse treatment in three different populations: Is there improvement and is it predictable?» Amerian journal of drug and alcohol abuse. 12 (1 \& 2), 101-120. 1986.

Marina, P.A.: Adictos a la Heroína en Asturias. Un estudio de seguimiento. Principado de Asturias. Oviedo. 1993.

Martínez de la Fuente, L., Arteagoitia, J.M.: «Estudio descriptivo de los pacientes heroinómanos asistidos en centros de tratamiento en el período 19811985». Comunidad y Drogas, 3, pp. 35-59, 1987.

Melgarejo, M., Sanahuja, P., Pérez, E., Masferrer, J., Sala, L.I., Piña, L.: «Estudio descriptivo de 431 heroinómanos usuarios del programa DROSS». Font informatiu, 5, noviembre. 1986.

Melgarejo, M., Sanahuja, P., Pérez, E., Masferrer, J., Sala, L.I., Piña, L.: «Tratamiento de 182 heroinómanos y resultados: seguimiento a un año (198586)». Font informatiu, 13, 1-141. 1988.

National Institute on DRUg Abuse: «"Effectiveness on drug abuse treatment program". Departament of health and human services». Publications n. (ADM) 81-1.143. 1981.

NAVARro, J.: «La incidencia de las drogodependencias en el medio laboral». Comunidad y Drogas, 7, pp. 9-30, 1988.

NiEvA, P.: Evolución de centros de tratamiento de la drogodependencia. Tesis doctoral. UNED. Madrid, 1988.

OTERO, S.: Estudio epidemiológico de toxicomanías no alcohólicas y evaluación de programas terapéuticos. Tesis Doctoral. Facultad de Medicina. Universidad de Cantabria. 1991.

Page, R.C., Mitchell, S.: «The effects of two therapeutic communities on illicit drug users betwen 6 months and 1 year after treatment». The international journal of the addictions. 22 (10), 981-992. 1988.

PinILla, B., SAlcedo, M.: «Sintomatología psíquica en pacientes de medicina general: avance de hipótesis». Actas luso-españolas de Neurología y Psiquiatría, 15: 6. 1987.

Research TRIAngle Institute: Increment and follow-up studies. (Treatment outcome prospective study, TOPS.) Data collections forms. Research triangle parck NC: RTI. 1982.

Robertson, J.R., Bucknall, A.B.V., Skidmore, C.A., Roberts, J.J.K., Smith, J.H.: «Remision and relapse in heroin users and implications for management: 
treatment control or risk reduction». The international journal of the addictions, 24 (3), 229-246. 1989.

ROGALSKY, C.J.: «Factor structure of the addiction severity index in an impatient destoxification sample». The international journal of the addictions, 22 (10), 981-992. 1987.

RoundsaVILle, B.J., Dolinsky, Z.S., BABOR, T.F.: «Psychopatholy as a predictor of treatment outcome in alcoholism». Archieves of General psychiatry, 44, 505-513. 1987.

Roundsaville, B.J., Kosten, T.R., Klever, H.D.: «Long term changes in current psychiatric diagnoses of treated opiate addicts». Comprehensive Psychiatry, 27 (5), 480-498. 1986.

Royo, J.: «Estudio de seguimiento de adictos a la heroína dos años después de haber finalizado el programa de abstinencia en régimen de ingreso (Comunidad terapéutica)». II congreso del colegio oficial de psicólogos, 239-251. Valencia. 1990.

SÁnCHEZ-CARbonell, J., CAMI, J.: «Recuperación de heroinómanos. Definición, criterios y problemas de los estudios de evaluación y seguimiento». Medicina clínica, 87 (9), 377-382. 1986.

SÁNCHEZ-CARBONELl, J.: «Conocimientos y valoración de las medidas y servicios de atención al toxicómano». Comunidad y drogas, 8, 9-24. 1988.

SÁnchez-CARbonell, J., CAMi, J., Brigos, B.: «Evolución de una muestra de heroinómanos 2 años después del inicio del tratamiento. (Proyecto EMETYST)». Medicina clínica, 92. Barcelona, 1988.

SEIT: Informe 1987, Informe 1988, Informe 1991. Ministerio de Sanidad y Consumo. Delegación del Gobierno para el Plan Nacional sobre Drogas. Madrid, 1988, 1989, 1992.

SELls, S.B.: Studies of effectivenes of treatment for drug abuse (Vol. 1). Evaluation of treatment. Ballinger press. Cambridge, Massachussets. 1974.

SELls, S.B., SimPSON, D.D.: «Evaluation of treatment outcomes for the 1971-72 admision cohort». In The effectiveness of drug abuse treatment (Vol. IV). Ballinger press, Cambridge, Massachussets. 1976.

SELls, S.B., SimPSON, D.D.: «Evaluation of treatment outcomes for the 1972-73 admision cohort». In The effectiveness of drug abuse treatment (Vol. V). Ballinger press, Cambridge, Massachussets. 1976.

Sells, S.B., Simpson, D.D., Joe, G.W., Demaree, R.G., Savage, L.J., Lloyd, M.R.: «A national follow-up study to evaluate the effectiveness of drug abuse treatment: a report on cohort 1 of the DRAP five years later». Amerian journal of drug and alcohol abuse, 3 (4), 545-556. 1976.

SIMPSON, D.D.: «The relation of time spent in drug abuse treatment to posttreatment outcome». Amerian journal of Psychiatry, 38, 875-880. 1981.

SIMPSON, D.D.: «National treatment system evaluation based on the drug abuser reproting programa (DARP) Follow-up research» en Drug Abuse Treatment Evaluation: Strategies progress and prospects. TIMS, F. LUDFORD, J. de. Research Monograph Series, 51, pp. 29-41. NIDA, Maryland, 1984.

SimpSON, D.D., SELLS, S.B.: «Effectiveness of treatment of drug abuse: an overview of the DARP research program. Adv. Alcohol substance abuse, 2 (1), 7-29. 1982. 
SimpSON, D.D., Sells, S.B.: Effectiveness of treatment of drug abuse: summary of DARP, Follow-up research. DHHS Pubs. No. (ADM) 82-1.194. Washington DC: U.S. Goverment Printing Office, NIDA. 1982.

Stimmel, M., GoldberG, J., Cohen, M., RatCopf, E.: «Detoxification for methadone maintenance: risk factors associated with relapse to narcotic use». Annals of N.Y. Accademy of sciences, 311, 173-180. 1979.

Stanton, M.D., TodD, T.: Terapia Familiar del abuso y adicción a las drogas. GEDISA. Barcelona. 1988.

Stimson, G.V., Oppenheimer, E., Thorley, A.: «7 year follow-up of heroin addicts: drug use and outcome». British medical journal, 1, 1.190-1.192. 1978.

VAILLANT, G.E.: «A 12-year follow-up of N.Y. narcotic addicts: I. The relation of treatment to outcome». Amerian journal of Psychiatry, 122, 727-737. 1966.

VAILLANT, G.E.: «A 12-year follow-up of N.Y. narcotic addicts: IV. Some characteristics and determinant of abstinence». Amerian journal of Psychiatry, 123, 573-585. 1966.

VAILlant, G.E.: «A 20-year follow-up of N.Y. narcotic addicts». Archieves general of psychiatry, 29, 237-241. 1973.

VAILLANT, G.E.: «What can long-term follow-up teach us about relapse and prevention of relapse in addiction?» British journal of addiction, 83, 1.147-1.157. 1988.

Vázquez Barquero, J.L., Díez Manríquez, J.F., Peña, C., y Aldama, J.M. y Cols.: «A community mental health sourvey in Cantabria. A general description of morbility». Psicological Medicine. 17. pp. 227-242. 1987.

WILSON, S.: «The effect of treatment in a therapeutic community on intravenous drug abuse». British journal of addiction, 73, 407-411. 1978.

WINICK, C.: «Maturing out of narcotic addiction». Bulletin on narcotics, 16, 1-9. 


\title{
LOS PRINCIPIOS GENERALES DEL DERECHO Y LA JUSTICIA
}

\author{
José Manuel Fernández Hierro
}

\begin{abstract}
No creo que nuestros edictos sean tan importantes
Como para que un hombre mortal rechazase

Las leyes no escritas e inmortales de los dioses

Cuya vida no es de hoy o de ayer

Sino de siempre y nadie sabe de dónde provienen

No me expondría al castigo de los dioses

Quebrantando estas leyes por temor a ningún hombre.
\end{abstract}

Sófocles, Antígona, 450-460.

Sumario: 1. Planteamiento. 2. La justicia a través del tiempo. 3. Los principios generales del derecho. 4. Conclusiones.

\section{Planteamiento}

Las palabras «derecho»y «justicia» son frecuentemente utilizadas, y las expresiones «tengo derecho a», «no es justo», «es una injusticia» y otras más, se usan en el lenguaje diario por la mayoría de los ciudadanos y son frecuentes oírlas o leerlas en los medios de comunicación social. Pero paradójicamente la voz justicia, tan usada, es una de las que han resultado más difíciles de definir ${ }^{1}$, tal vez por las acepciones encontradas que a la misma se han dado y por la pluralidad de significados que de la misma se puede encontrar:

No es ninguna novedad el resaltar la ambigüedad del concepto de justicia que ya en su día observó Aristóteles²:

«Ahora bien, justicia e injusticia parecen ambiguos pero como sus significados diferentes se aproximan uno al otro la ambigüedad pasa inadvertida, no siendo tan claro y manifiesto como es, comparativamente cuando los significados están muy alejados».

\footnotetext{
1 Ya advertía IsOCRATES (Contra los sofistas XII-21) que la justicia no es cosa enseñable aun cuando debe ser practicada.

2 Etica a Nicómaco, libro V, capítulo 1.․
} 
En nuestros días ha subrayado Kelsen ${ }^{3}$ :

«En consecuencia, la ciencia del derecho no puede declarar que tal orden $-\mathrm{o}$ tal norma jurídica - es justo o injusto, pues tal juicio se funda, ya sea en una moral positiva, es decir en un orden normativo diferente e independiente del derecho positivo, o en un verdadero juicio de valor con carácter subjetivo.

Además la idea de la justicia no se presenta casi nunca como un valor relativo, fundado sobre una moral positiva establecida por la costumbre, y por esta razón diferente de un lugar a otro, de una época a otra. En su sentido propio la idea de justicia es un valor absoluto, un principio que pretende ser válido siempre y en todas partes, independientemente del espacio y del tiempo: es eterna e inmutable. Ni la ciencia del derecho positivo ni ninguna otra ciencia pueden determinar su contenido, que varía al infinito».

Y si algo parecido nos sucede con la palabra derecho el encontrar los principios generales del mismo no es tampoco tarea fácil, como tampoco el ver la relación que en los principios generales de derecho puedan tener con el derecho o con la justicia en abstracto, aun cuando, si aceptamos la teoría de Wittgestein ${ }^{4}$, dado que podemos formular la pregunta debemos responderla.

La modificación del título preliminar del Código Civil y la entrada en vigor de la Constitución pudieron dar nuevos datos para una polémica más centenaria. En estas páginas voy a tratar de sintetizar y resumir la relación entre los anteriores conceptos.

\section{La justicia a través del tiempo}

La Biblia tiene una elevada consideración de la justicia:

«Y de la justicia haré regla y del derecho haré mi ley ${ }^{5} »$.

La justicia nos señala el camino ${ }^{6}$ :

«Entenderás entonces justicia, juicio, equidad, en suma buen camino».

Sin embargo si se tiene un alto concepto de la justicia y se reitera en numerosos pasajes la necesidad de la misma, no aparece un claro

\footnotetext{
${ }^{3}$ Teoría pura del derecho, Buenos Aires, 1973, pp. 60 y ss.

${ }^{4}$ Tractatus logicus filosoficus, n. $^{\circ} 6.5$.

5 IsAÍAS, 28-17.

6 Proverbios 2-8.
} 
concepto de la misma: se insiste en que hay que practicar la justicia y guardar el derecho ${ }^{7}$ pero el contenido de la misma no es enumerado con nitidez.

Tal vez una de las citas más detalladas es la que se contiene en el libro de Ezequiel ${ }^{8}$ :

«El que sea justo y haga justicia, no banquetee por los montes, y no alce sus ojos a los ídolos de la casa de Israel, no manche a la mujer de su prójimo, y no llegue a la menstruada, que no time a nadie y devuelva al deudor su prenda, y no robe y dé pan al hambriento y vestido al desnudo, no dé a logro ni reciba a usura, retraiga su mano del mal, y haga juicio de verdad entre hombre y hombre, camine mis mandatos, obre mis leyes obrando rectamente, ése es justo, vivirá, dice Yavéh».

De la cita transcrita se deriva que el concepto de justicia para el Antiguo Testamento está íntimamente ligada con el de religión y, en definitiva, la justicia supone el cumplimiento de una serie de deberes, que si bien afectan en ocasiones a las relaciones de una persona con los demás, pueden también referirse exclusivamente a la relación de la propia persona con Dios.

«Esta idea (la de la justicia) desempeña un papel importante en el Antiguo Testamento y comprende no sólo la estricta justicia aristotélica sino la totalidad de los deberes civiles del hombre. El concepto israelita de justicia se aproxima, pues, a nuestras ideas de santidad, piedad, integridad y rectitud» (...) «Justo es aquél que vive conforme al beneplácito de Yavéh (Génesis 6,9 y 7,1) que sigue la ley de Yavéh (Isaías 3,10 Ezequiel 3,20 $)^{9} \gg$.

A pesar de ellos y sin que suponga contradicción con lo anterior, en determinados pasajes bíblicos la justicia tiene un significado parecido a su acepción corriente actual: así cuando se señala que «tendrás pesas cabales y justas, medidas cabales y justas» ${ }^{10}$ y cuando se indica: «oíd a vuestros hermanos, juzgad según justicia las diferencias que pueda haber entre ellos o con extranjeros» ${ }^{11}$; pero, en conjunto, el sentido del Antiguo Testamento es el señalado de justicia como rectitud o santidad $^{12}$.

7 ISAÍAS 56-1.

8 EZEQUiEl 18. 5-9.

9 H. HaAg y A. Van Den Born, Diccionario de la Biblia, Barcelona, 1963, p. 1.057.

10 Deuteronomio 25, 15.

11 Deuteronomio 1, 16.

${ }^{12}$ Véase Descamp, «Justicia» en Vocabulario de teología bíblica. Barcelona, 1973, pp. 460 y ss. 
La evolución sufrida a lo largo de la historia por el judaísmo no afectó a este concepto (aun cuando sí puede hablarse de un cambio importante en el Nuevo Testamento, sobre todo en los escritos paulinos, en el que las referencias a la justicia cambian de sentido acercándose al concepto de justificación por la $\mathrm{fe}^{13}$ ) sino, tal vez, al contrario:

«Los profetas critican la praxis jurídica de los que mandan, el desprecio del derecho por las clases altas, las omisiones y transgresiones de funcionarios y jueces que declaran inocentes a los culpables, condenan a los inocentes, dejan en la estacada a huérfanos y viudas en lugar de preguntarse por el sentido y el espíritu del derecho y dejar que hable el corazón en aplicación de la Ley ${ }^{14}$.

Tal concepción no fue única de la Biblia. Así en el antiguo Egipto:

«La Justicia no es una noción relativa; no depende de los hombres sino del Ra que fija sus reglas, la justicia es una cosa divina y por lo mismo está representada por una diosa Maat, hija del gran dios creador, en otras palabras la justicia emana directamente de Dios: "La justicia es grande, invariable, segura y no ha sido turbada desde la época de Osiris" que la dio a conocer a los hombres. "Los límites de la justicia son invariables, es una enseñanza que cada hombre adquiere de su padre", pero si es verdad que emana de Dios entre los hombres se traduce por la Ley. Por consiguiente, la ley se impone a los hombres como una obligación moral. Es la base del orden social, de la propiedad: "oponer obstáculos a la ley es abrir la puerta a la violencia". No es posible que un hombre pueda decir: "Yo me apodero de esto porque es mi deseo» sino que dirá: "Lo tomé porque es mi derecho ${ }^{15}$ "》.

Y lo mismo sucede en la antigua Mesopotamia ${ }^{16}$ :

«Amin y Enlil me señalaron a mi Hammurabi, príncipe piadoso, temeroso de mi dios, para proclamar el derecho en el País, para destruir al malvado y al perverso, para impedir que el fuerte oprimiera al débil».

Platón fue probablemente el filósofo que en la antigüedad dedicó más páginas al tratado de la justicia en varias de sus obras, ya que según señala no hay crimen mayor contra la ciudad que cometer injusticia con ella ${ }^{17}$.

13 Véase López Aranguren, «Catolicismo y protestantismo como formas de existencia» en Obras, tomo 1, pp. 266 y ss. Madrid, 1965.

${ }^{14}$ Hans Kung, Judaísmo, Barcelona, 1994, p. 128.

15 Pirenne. Historia del Antiguo Egipto, tomo 1, p. 251.

16 Código de Hammurabi, versículos del 20 al 40. Véase tambien Brice PARAIn, Historia de la Filosofía, V.I., «El pensamiento prefilosófico y oriental», Madrid, 1969, p. 41.

17 En La república, libro 4. ${ }^{\circ}, \mathrm{X}, 434 \mathrm{C}$. 
Sin embargo su concreción tampoco es clara, aunque de algunos pasajes de Platón parece deducirse que la justicia es la aplicación práctica de las normas de la ciudad ideal que él había diseñado ${ }^{18}$.

Para Aristóteles hay que puntualizar como:

«Observemos que todos entienden por justica el hábito que hace que las personas se hallen en disposición de efectuar lo justo, inclinándoles a obrar justamente y desear lo justo; y del mismo modo entienden por justicia el hábito que les hace obrar injustamente y desear lo injusto ${ }^{19}$ ».

El Derecho Romano relacionó derecho y justicia hasta el punto de que en su versión clásica el derecho es precisamente el arte de lo justo y de lo injusto, y de que el ius es, de acuerdo con la conocida definición de Celsol ars boni et aequi.

Cicerón señaló como base de la justicia:

«Fundamentum autem es iustitiae fide, id est dictorum conventorum constantia et veritas ${ }^{20} »$.

La otra definición clásica contenida en el Digesto enlaza la justicia con el derecho de cada uno:

«Iustitia est constans et perpetua voluntas ius suum cuique tribuere ${ }^{21} \gg$.

La idea de la justicia ha ido ligada con el iusnaturalismo a través de la tradición aristotélica y medieval ${ }^{22}$, y posteriormente de Grocio y los autores de las escuelas holandesa y española del derecho natural, hasta la reacción positivista contra éste.

Se ha señalado que precisamente la característica del positivismo es la negación del derecho natural, limitándose, como su nombre indica, al derecho positivo emanado de las autoridades competentes: para el positivismo puro el fundamento último del derecho está en el poder del estado y no tiene ningún fundamento metajurídico.

Por tanto el positivismo combatió la idea de la justicia abstracta y enlazó los principios generales del derecho, con los del derecho positi-

18 Obra citada, libro 4. ${ }^{\circ}, \mathrm{Xl}, 434 \mathrm{C}$.

19 Etica a Nicómaco, libro V, cap. I.

20 De officiis, 1,7

${ }^{21}$ Digesto, 1, 1, 10. En análogo sentido Instituciones 1.1. La equivalencia entre derecho natural y justicia la encontramos en Digesto $1,1,11$.

${ }^{22}$ La idea del derecho natural la encontramos en ArIstóteles, Etica a Nicómaco, libro $\mathrm{V}$, capítulo VII. 
vo vigente, obteniendo un notable éxito en su empresa ${ }^{23}$, ya que como señala Radbruch ${ }^{24}$ :

«Si nadie es capaz de fijar lo que es justo, alguien tiene que establecer lo que sea el Derecho».

Para buscar una justificación al ordenamiento jurídico Stammler acuñó la expresión de derecho justo: ahora bien, para Stammler el derecho justo es el derecho establecido, el derecho positivo con lo cual el parámetro para medir de la justicia de un derecho es la coherencia de la norma con el ordenamiento jurídico ${ }^{25}$. Con tal posicionamiento trató de crear una vía intermedia entre la idea del derecho natural y el positivismo, aunque tal vez inclinándose hacia el positivismo, si bien señalaba que el impulso con lo justo es consustancial con la existencia misma del derecho ${ }^{26}$.

Algunos ordenamientos jurídicos recogen expresamente esta concepción: así el artículo 12 del Código Civil Italiano de 1942 alude a la aplicación de la ley según la intención del legislador y a los principios generales del ordenamiento jurídico de Estado; y el artículo 8 del Código Civil Portugués señala que el deber de obediencia a la Ley no puede ser contrarrestado por la alegación de que ésta es injusta o inmoral.

Sin embargo, después de la Segunda Guerra Mundial los hechos en ella cometidos, en especial el descubrimiento de las atrocidades nazis, impulsaron un resurgimiento del concepto de justicia abstracta, dado que si el único concepto del derecho era el del derecho vigente no había parámetro para medir y condenar tales actuaciones, que se ajustaban en un todo a la legalidad vigente y a los principios generales del derecho derivados de esa legalidad por muy repugnantes que parecieran.

En nuestro país, De la Vega Benayas ${ }^{27}$ ha sido partidario de que el juez pueda decidir contra la ley partiendo de su deber de dictar una decisión justa.

Hans Kelsen ha criticado la vuelta al naturalismo señalando que:

«La justicia absoluta es un ideal irracional. Por indispensable que pueda ser a la voluntad y a la acción escapa al conocimiento racional y

23 O en todo caso del Derecho Romano como quería Del VeCCHIO, en Los principios generales del derecho, Barcelona, 1979, pp. 43 y ss.

${ }^{24}$ Citado por Welzel, «El problema de la validez del derecho», en Derecho injusto y el derecho nulo, Aguilar, Madrid, 1971, p. 102.

25 Véase Karl Larenz, Derecho justo. Fundamentos de ética jurídica, Cívitas, Madrid, 1985, pp. 21 y sigs.

${ }^{26}$ StammLer, Die Pehre Von Richtigen Rochte, p. 57, citado por LARENZ en obra citada, p. 28.

27 Introducción al Derecho judicial, Madrid, 1970, p. 240. 
la ciencia del derecho sólo puede explorar el dominio del derecho positivo. Cuanto menos nos empeñamos en separar netamente el derecho de la justicia, en mayor grado mostramos indulgencia con respecto al deseo del legislador de que el derecho sea considerado como justo y más cedemos a la tendencia ideológica que la caracteriza la doctrina clásica y conservadora del derecho natural. Esta doctrina no busca conocer el derecho en vigor como justificarlo y transfigurarlo destacando que emana de un orden natural, divino o racional; por lo tanto absolutamente justo y equitativo. La doctrina revolucionaria del derecho natural, que desempeña en la historia de la ciencia del derecho un papel relativamente oscuro, tiende al fin opuesto. Pone en duda la validez del derecho positivo, afirmando que está en contradicción con un orden absoluto cuya existencia postula. Presenta así al derecho bajo una luz que lo hace aparecer a veces mucho más imperfecto de lo que es en reali$\operatorname{dad}^{28} \gg$.

Cualquiera de los puntos de vista que adoptemos tiene sus limitaciones: la opción de un criterio de justicia trascendente al derecho positivo nos puede abocar a una inseguridad jurídica, mientras que el criterio contrario nos conduce a aceptar las pautas señaladas por el legislador, fueran las que fueran. Aun cuando los dos criterios tienen sus inconvenientes, es más grave el de aceptar indiscriminadamente los principios que siente el legislador positivo por muy aberrantes que fueran.

Para tratar de superar estos problemas se ha caracterizado a la justicia como igualdad y como imparcialidad, cuyo antecedente está en Aristóteles $^{29}$. Rawls, uno de los autores modernos que más ha profundizado este problema, señala:

«La justicia con imparcialidad comienza, como he dicho, con una de las selecciones más generales que las personas pueden hacer en común, esto es con la elección de los primeros principios de una concepción de la justicia, que habrá de regular toda la crítica y reforma subsecuente de las instituciones. Por tanto, después de haber escogido una concepción de la justicia, podemos suponer que escogerán una constitución y un poder legislativo que promulge las leyes, de acuerdo siempre con los principios de la justicia convenidos originariamente. Nuestra situación social es justa si a través de esta secuencia de acuerdos hipotéticos hubiéramos convenido un sistema general de reglas que la definie$\operatorname{ran}^{30} \gg$.

8 Obra citada, pp. 62 y ss.

Etica a Nicómaco, libro V, capítulo III.

30 Teoría de la justicia, Madrid, 1978, p. 30. 
Si bien la justicia entendida de manera formal se ha ligado fundamentalmente al concepto de igualdad, hay que tener en cuenta que tal aplicación no puede ser automática porque sólo partiendo de supuestos y situaciones equivalentes se puede hablar de igualdad de trato. Continúa diciendo Rawls:

«Esta idea de la justicia ligada a la igualdad en cuanto al debe, sin duda alguna, mucho a la asociación de la justicia con los procedimientos jurídicos. Se supone que la Ley ha de ser aplicada igualmente en todas las situaciones y a todas las personas a las que se refiere sin miedo ni favor; a ricos y a pobres, a poderosos y a humildes por igual, se puede considerar la encarnación de la justicia a aquella ley que se aplica sin discriminación alguna. Lo que también ha de subrayarse es que la justicia en este sentido no es realmente más que un principio formal de igualdad. Ni siquiera puede considerársela un principio de igualdad sin más cualificación. La justicia no puede significar tampoco que vamos a tratar a todos del mismo modo sin tener en cuenta las diferencias individuales, porque eso nos obligaría, por ejemplo, a condenar con la misma pena a todo aquel que haya matado a una persona, sin tener en cuenta factores tales como la incapacidad mental, o la minoría de edad del acusado. Lo que este principio significa realmente es que los semejantes sean considerados como semejantes, por lo que todo aquel que esté clasificado como perteneciente a la misma categoría, en relación con un objetivo particular, será tratado de la misma manera».

Y en el mismo sentido puntualiza Lloyd:

«La idea de justicia encarnada en el principio de tratar casos semejantes de un mismo modo parece implicar cuando se amplía tres concepciones relacionadas: primero que habrá normas establecidas de cómo debe tratarse a la gente en casos dados; segundo, que estas normas serán de carácter general, es decir, que dispondrán que todo aquel que entre en el marco de una norma será regido por ésta. (En otras palabras, debe aplicarse o bien de un modo general a todas las personas, o bien a ciertas categorías de persona especialmente definidas, y no individuos al azar). En tercer lugar la justicia requiere que estas normas generales sean aplicadas imparcialmente, es decir, que los órganos encargados de administrarlos las apliquen sin discriminación, ni miedo, ni favor, a todos aquellos que entren en el marco de las normas ${ }^{31}{ }^{1}$.

Como antes he indicado la primera distinción que hay que mantener es la de justicia material y justicia formal, ya que la que constituye un desarrollo de la idea de igualdad es la justicia formal como señala Latorre ${ }^{32}$ :

\footnotetext{
31 La idea del derecho. ¿Perversidad represora o justicia social? Madrid 1985, p. 132.

32 Justicia y derecho, Barcelona, 1973, p. 23.
} 
«Así, la idea de justicia lleva aparejada la de "igualdad". Los casos iguales habrán de ser valorados de igual modo y los desiguales de desigual manera. Si en un examen dos estudiantes demuestran igual preparación, todos consideramos justo que obtengan la misma nota. Pero si uno hace un examen mejor que otro nos parecerá así mismo justo que aquél obtenga una nota más alta. La igualdad y por tanto, la justicia, supone que si una regla debe regir para todos, nadie puede infringirla en beneficio propio y perjuicio ajeno».

Ciertamente ello es así en cuanto al aspecto formal de la justicia que sería infringido cuando se trata con distintas varas de medir situaciones iguales. Pero sin embargo, difícilmente con ello podemos llenar el contenido material de la justicia: siguiendo el ejemplo de Latorre podemos entender que es injusto el suspenso del estudiante que ha hecho igual el examen que otros que han aprobado (aspecto de la igualdad como contenido formal de la justicia), pero tal ejemplo no nos vale para señalar cuando debemos aprobar al segundo estudiante, o si un ordenamiento jurídico es justo o no.

Pensemos también en una hipotética norma que impusiera la eutanasia a todas las personas al cumplir una determinada edad: tal norma difícilmente podría ser tachada de injusta con la sola invocación del principio de igualdad. Para denunciarla habría que acudir a principios que estuvieran por encima de la misma.

¿Se podría entender que los principios de la justicia son los mismos que los de la moral? Derecho y moral son distintos, y como señala Legaz y Lacambra ${ }^{33}$ el derecho no existe para la persona íntima, sino sólo para la persona social o socializada.

El punto de mira del derecho y la moral son diferentes y por tanto, aun cuando parcialmente coincidentes, tales principios metajurídicos no pueden serlo de la moral: el ciudadano debe saber distinguir entre lo que es ilícito y lo que es moral, y que se trata de dos parámetros que no tienen por que coincidir, aunque el derecho sea el óptimo posible.

$\mathrm{Y}$ no solamente no coinciden en cuanto a su objeto (la actuación global del hombre en la moral y la actuación externa de éste, en cuanto tenga relación con los demás en el derecho distinción que se remonta a Santo Tomás ${ }^{34}$ ) sino que incluso dentro del campo común las soluciones de ambos pueden ser distintas: pensemos en la prescripción extintiva, por ejemplo que, en aras de la seguridad jurídica, introducen casi todos los ordenamientos positivos, prescripción que sería inexistente en el campo moral.

\footnotetext{
${ }^{33}$ Horizontes del pensamiento jurídico, Barcelona, 1947, p. 95.
}

${ }^{34}$ Summa theologica II-AE, 157, A1. 
Ello no es óbice tengamos en cuenta, como acertadamente observa Legaz y Lacambra ${ }^{35}$ que es difícil separar hombre jurídico y hombre moral; y aunque la situación de asignar la moral a la conciencia individual y el derecho al ordenamiento estatal en opinión de De los Mozos ${ }^{36}$ no se atiene a la esencia y alcance de uno y otro y desconoce de alguna forma la tradición culta que debe anteceder a la formulación de cualquier obra legislativa, una cosa es que la moral haya influenciado en la formación del derecho en nuestro sistema jurídico y otra diferente es hacerlo coincidente ${ }^{37}$.

Tales principios podrían ser los del propio ordenamiento jurídico en su «impulso hacia lo justo» que señalaba Stammler; pero para ello hace falta que del conjunto del ordenamiento jurídico puedan estarse unos principios que justifiquen la calificación de injusta a una ley determinada.

Las referencias a lo que debe entenderse materialmente por derecho justo no son fáciles de encontrar.

Prueba de tal imprecisión son las conclusiones que extrae Dennis Lloyd:

«Existen dos formas principales en que un sistema jurídico puede aspirar a alcanzar no sólo la justicia puramente formal, sino también sustancial, en la medida en que se reflejan en el sistema de valores que actúa en una comunidad en particular. De las dos, la primera es más limitada, pero es de alguna forma más penetrante a largo plazo. Se trata de impartir una cierta flexibilidad a los tribunales y los órganos de la administración de justicia a fin de conferir a los jueces y a los demás funcionarios legales la posibilidad de desarrollar la Ley y adaptarla a las necesidades de la sociedad en que actúa, y otro fijar la inclusión de los derechos en normas fundamentales constitucionales, las cuales no descartan el iusnaturalismo entre otras por los términos originales en que están concebidos y que dejan margen amplio para interpretaciones contradictorias e incluso a nivel judicial» ${ }^{38}$.

Sin gran éxito Herbada ${ }^{39}$ señala para salvar esta dificultad que la justicia consiste en dar a cada uno su derecho, solución más aparente que real porque si el dar a cada uno su derecho viene determinado por

35 Introducción a la ciencia del derecho, Barcelona, 1943, p. 224.

36 «El derecho natural en la formación de derecho civil» en Revista de Derecho Privado, abril 1969, p. 245.

37 Véase al respecto Soto NiETo, «Coincidencia y diferenciación práctica del derecho y la moral» en Cuestiones jurídicas. Jurisprudencia creadora, tomo I, pp. 17 y ss.

${ }^{38}$ Obra citada, p. 146.

${ }^{39}$ Lecciones de Filosofía del derecho, teoría de la justicia del derecho. Pamplona, 1989, p. 113. 
éste, difícilmente podremos tachar al ordenamiento de injusto a no ser que acudamos a un conjunto de normas supralegales, como hace Herbada con el derecho natural.

Tal solución es posible, y es más, como queda reflejado a lo largo de estas páginas, el derecho natural ha tenido una importante revalorización en el pensamiento jurídico de la segunda mitad del siglo Xx; pero en esta hipótesis habrá que convenir con Lumier ${ }^{40}$ que la búsqueda de la justicia está más allá del derecho, o, al menos, del derecho positivo:

«El problema de la justicia es el problema de la búsqueda de criterio en base al cual pueden valorarse como justas o injustas una conducta determinada y la norma en que ésta aparece inspirada. Es decir, la justicia no es más que un criterio de valoración o, como se suele decir más brevemente, un valor, y precisamente el valor se realiza a través del apartado del Derecho. El problema de la justicia no es otra cosa que el problema de los valores jurídicos, de su fundamento y de sus contenidos. De ahí resulta manifiesto que está íntimamente ligado al problema de los valores en general pues, en definitiva, no es más que un aspecto particular de su problema y por ello debe ser estudiado con referencia a él».

Ciertamente la aceptación del derecho natural puede ser una solución y un punto de apoyo más allá del derecho positivo ${ }^{41}$; el problema estaría en las controversias sobre el relativismo o universalismo del derecho natural y la difícil obtención en él de respuestas claras y unívocas y universales a cualquier punto jurídico que se plantee. Por eso se ha tratado de buscar otros esquemas como básicos de la justicia; esquemas fundados en la organización más racional de la vía en común. Así para Rawls ${ }^{42}$ los principios de la justicia serían:

«Primero: Cada persona ha de tener un derecho igual al esquema más extenso de libertades básicas iguales que sean compatibles con un esquema semejante de libertades para los demás.

Segundo: Las desigualdades sociales y económicas habrán de ser conformadas de modo tal que a la vez que:

a) Se espere que sean ventajosas para todos.

b) Se vinculen a empleos y cargos asequibles para todos».

40 Principios de teoría e ideología del derecho, Madrid, 1985, pp. 114 y ss.

41 No en vano se ha señalado que el núcleo del iusnaturalismo moderno son los derechos del hombre como persona moral. Así lo indica Helmut CoING en Fundamentos de Filosofía del Derecho, Barcelona, 1961, p. 186.

42 Obra citada, p. 82. 
En cualquier caso los criterios de la justicia siguen siendo poco nítidos: el conformar las desigualdades económicas de forma que sean ventajosas para todos no supone una respuesta a los interrogantes concretos que puedan plantearse a la vista de una norma específica. Tal vez habría que observar que si la constitucionalidad o no de una ley no es fácil de determinar, a pesar de la existencia de una constitución escrita, mucho más lo es el precisar si la misma ley se adapta o no a los principios de la justicia que no están, por esencia, escritos en ningún texto positivo.

No obstante sí pueden darse algunas pistas o criterios; y así Lumier señala que los dos principios que deben guiar la búsqueda de la justicia son la seguridad y la libertad (tomando como equivalentes libertad e igualdad).

La posibilidad de invocar tales principios puede darse en algunos ordenamientos jurídicos y así puede mantenerse que en nuestro derecho, y en la mayoría de las constituciones políticas de los Estados democráticos se pueden dar y sustento a la invocación de tales valores, basándose en los principios en los que se funda la constitución; y que en el ámbito internacional podrían encontrar su apoyo en el convenio europeo para la protección de los derechos humanos y en la declaración universal de derechos humanos.

Por ello es posible que dentro del propio ordenamiento jurídico y de la constitución ${ }^{43}$ encontremos una base para tachar de injusta una ley.

Ahora bien, tal alegación no siempre será efectiva, ya que determinadas leyes - un ejemplo pueden ser la del exterminio de los judíos en la época nazi- claramente injustas eran coherentes con el ordenamiento jurídico en el marco del cual eran dictadas, sin que tampoco existiera una constitución que las desautorizara.

En tal hipótesis tendríamos que referirnos a un concepto de justicia por encima de cualquier tipo de derecho positivo, enlazando con el derecho natural. Como señala Hegel ${ }^{44}$ :

«Cuando al derecho positivo y las leyes se oponen el sentimiento del corazón, las inclinaciones y el arbitrio, no será la filosofía quien reconozca tales autoridades. Que la fuerza y la tiranía pueden ser un elemento del derecho positivo, es para el contingente y no pertenece a su naturaleza».

El contenido del derecho natural así como su propia existencia ha sido objeto, como queda indicado de amplias controversias a través de

43 Además de poderla atacar por anticonstitucionalidad que es alegación diferente.

44 Principios de filosofía del derecho, Barcelona, 1988, p. 58. 
la historia: admitido por Aristóteles ${ }^{45}$, Cicerón, el derecho romano y la escolástica fue rechazado por el positivismo. Aunque, con todos sus inconvenientes e imprecisiones, parece el único punto de apoyo contra los posibles excesos de un derecho despótico, la incertidumbre de su contenido, e incluso la negación de su existencia, nos llevan a preguntar si la finalidad del derecho natural no puede ser reemplazada por los principios generales del derecho.

\section{Los principios generales del derecho}

La fijación de los principios generales del derecho es controvertida: Cicerón indicó que los principios generales del derecho no eran los del derecho vigente, sino superiores a ellos e íntimamente relacionados con los principios filosóficos ${ }^{46}$; determinados códigos civiles hacen referencia explícita a los principios generales del derecho.

Desde esta perspectiva los problemas existentes en torno a la existencia y contenido del derecho natural de alguna forma se trasladan a la fijación de los principios generales del derecho, siendo, en el fondo, la elección de derecho natural o principios generales del derecho como criterios últimos en que fijar el concepto de justicia una cuestión más semántica que de contenido real; pero que al menos en nuestro ordenamiento jurídico tiene la ventaja de basarse en una norma concreta en cuanto a su posible aplicación, cuál es el artículo 1.4 del Código Civil; aun cuando no puede dejarse de notar la paradoja que ello pueda suponer al tratar de encuadrar dentro del ordenamiento positivo unos fundamentos del derecho que se suponen están, por esencia, encima y al margen de tal ordenamiento.

En tal sentido, por ejemplo, se pronunció García Valdecasas ${ }^{47}$, que señalaba cómo los principios generales del derecho «están en toda fuente del Derecho y, por tanto, no habrá propiamente una superioridad de la ley entre ellos, pues el sentido de la ley tiene que ser conforme a los principios generales del Derecho».

Precisa a este respecto Elías de Tejada ${ }^{48}$ :

«No se trata de la baladí archisabida minucia de saber si es anterior el huevo a la gallina o viceversa. Es que si son principios filosófi-

45 Etica a Nicómaco, libro V, capítulo VII.

46 De legibus I, IV, 17.

47 El problema de las fuentes del derecho, Conferencia en la Universidad de Deusto, 1955 , p. 13

48 «Los principios generales del derecho en el art. 1 del Código Civil reformado en 1973», en Estudios sobre el título preliminar del Código Civil, vol. I, Madrid 1977, p. 92. 
cos además de informar al ordenamiento jurídico estarán por encima de él, y servirán para medirlo y en su caso corregirlo. Mientras que si no son reconocidos más que los principios de que ya informan a la ley y a la costumbre carecerán de autonomía, y estarán encarcelados en la cárcel del mismo ordenamiento vigente».

En derecho comparado la referencia a los principios generales del derecho existen varios ordenamientos: así el Código Civil austriaco refiriéndose en su artículo 7 al derecho natural, y el Código Civil italiano de 1865 el cual parece ser pasó a nuestro Código Civil.

En la configuración de los principios generales del derecho además de los dos puntos de vista antagónicos que los refieren respectivamente al derecho natural o al de los principios que se deducen del conjunto del ordenamiento ha habido otras posiciones intermedias, como la de Del Vecchio que pretende sustituirlos por los del derecho romano - si bien teniendo al derecho romano como expresión y cristalización del derecho natural- o eclécticas, como la de Albaladejo ${ }^{49}$ que señala que los principios generales del derecho son «las ideas fundamentales que informan nuestro Derecho positivo contenido en Leyes y costumbres y, en última instancia aquellas directrices que derivan de la justicia tal y como se entiende por nuestro ordenamiento jurídico». Mientras que para Helmunt Coing ${ }^{50}$ :

«La idea del derecho es, según esto, la suma de los contenidos morales (valores) que están ligados al desarrollo del derecho».

Alguna sentencia del Tribunal Supremo dictada bajo la redacción primitiva del Código Civil ha manifestado incluso que a él le está encomendada «la elevada misión de aplicar los principios generales del derecho» ${ }^{51}$.

La jurisprudencia anterior a la reforma del Código Civil había señalado que los principios generales del derecho sólo son aplicables cuando se alegan en defecto de Ley y de costumbre ${ }^{52}$, que no lo son las opiniones de los tratadistas ${ }^{53}$, y que deben estar reconocidos como tales en la ley y en la doctrina legal para que puedan servir de base a un recurso de casación ${ }^{54}$, incluso señalando que hace falta más de una sola sentencia del Tribunal Supremo que lo reconozca ${ }^{55}$.

\footnotetext{
49 Derecho Civil, tomo I, Barcelona, 1975, p. 93.

50 Fundamentos de filosofía del derecho, Barcelona, 1961, p. 158.

51 S. 12 de junio de 1926.

52 Ss. entre otras de 18 de marzo de 1931, Ar. 1.978 y 4 de junio de 1964, Ar. 3.876.

53 S. 31 de octubre de 1953, Ar. 2.914.

54 Ss. 3 de diciembre de 1928 y 10 de junio de 1966, Ar. 3.026.

55 Ss. 14 de marzo de 1953, Ar. 1.619 y 14 de mayo de 1964, Ar. 3.876.
} 
Ciertamente la antigua redacción del art. 1.691.1 de la Ley de Enjuiciamiento Civil que señalaba como motivo de recurso de casación el que el fallo contenga dilación, interpretación errónea o aplicación indebida de las leyes o doctrinas legales aplicables al procedimiento objeto del recurso.

La no inclusión como motivos del recurso de la violación de los principios generales del derecho y sí de la doctrina legal ha podido contribuir a la equiparación de doctrina legal con principios generales del derecho reconocidos y, en definitiva, a hacer pasar a aquéllos por el filtro de la jurisprudencia.

Se ha criticado tal interpretación señalando que el Tribunal Supremo no es quien para buscar los principios generales del Derecho que estarán no en su sede, sino que son patrimonio de los filósofos del derecho ${ }^{56}$.

Como es sabido el artículo 1.4 del Código Civil en su actual redacción señala:

«Los principios generales del derecho se aplicarán en defecto de ley o costumbre sin perjuicio de su carácter informador del ordenamiento jurídico» ${ }^{57}$.

Mientras que en su primitiva redacción el artículo 6.2 del Código Civil indicaba que «cuando no haya Ley exactamente aplicable al punto controvertido se aplicará la costumbre del lugar y, en su defecto, los principios generales del Derecho».

La nueva redacción del título preliminar del Código Civil no señala, como subraya Batlle ${ }^{58}$, a qué principios generales del derecho se aluden; y la supresión del texto inicial del artículo 1.691.1 de la Ley de Enjuiciamiento Civil ${ }^{59}$ puede abonar más la interpretación amplia de los principios generales del derecho no limitándolos a los del ordenamiento jurídico vigente, y en ese sentido, rechazando la limitación que supondría tener en cuenta solamente tales principios, se ha pronunciado Díez Picazo ${ }^{60}$.

Después de la modificación del Código Civil el Tribunal Supremo ha continuado exigiendo la necesidad de que tales principios hayan sido recogidos por la jurisprudencia para que puedan dar pie a la casación ${ }^{61}$.

56 Elías de TeJAdA, obra citada, p. 94.

57 Tal redacción fue introducida por la Ley de 17 de marzo de 1973.

58 Comentarios al Código Civil, tomo I, Madrid, 1978, p. 56.

59 El artículo 1.692.4. ${ }^{\circ}$ de la Ley de Enjuiciamiento Civil que es el texto sustitutorio señala: «Infracción de las normas del ordenamiento jurídico o la jurisprudencia que fueren aplicables para resolver las cuestiones objeto de debate».

60 En Comentarios al Código Civil, Madrid, 1991, tomo I, p. 11.

61 Ss. 7 de febrero de 1972, 12 de junio de 1980, Ar. 2.404 y 22 de febrero de 1993, Ar. 1.218 entre otras. 
Lo que también ha precisado el Tribunal Supremo es que los principios generales del derecho sólo se aplicarán en defecto de ley o costumbre ${ }^{62}$, cercenando de esta forma el propio contenido del artículo 1.4 del Código Civil e insistiendo en esta postura después de la reforma del título preliminar del mismo; ya que de acuerdo con el nuevo artículo 1 no sólo se aplican en defecto de ley o de costumbre, como antes señalaba el artículo 6 de dicho cuerpo legal: el carácter informador del ordenamiento jurídico que contiene la redacción actual del artículo 1.4 parece haber sido olvidado por el Tribunal Supremo, que no lo ha reconocido en los fallos tenidos con posterioridad a la modificación del título preliminar del Código Civil.

Cuestión distinta e importante es la de la posible modificación de los principios generales del derecho por la promulgación de la Constitución y la interacción entre ésta y aquéllos.

Se ha dicho ${ }^{63}$ que la «mutación de los principios políticos supone necesariamente una mutación de todo el ordenamiento jurídico»; y tal axioma es sobre todo aplicable cuando se trata de los principios generales del derecho.

Por eso se ha planteado el problema de entender si los principios generales del derecho al que alude el artículo 1 del Código Civil, deben ser los contenidos en la Constitución y que éstos deben ser aplicables a todo el ordenamiento jurídico.

Algún sector de la doctrina ha entendido que la Constitución de 1978 no recoge unos principios políticos determinados y que por tanto no es posible deducir de la misma unos principios de aplicación general para el ordenamiento jurídico dada la ambivalencia de sus preceptos que pueden servir tanto a una sociedad capitalista como a una sociedad socialista ${ }^{64}$.

No obstante y a pesar del sentido ambiguo que se le pueda dar al artículo 9.2 de la Constitución, piedra de toque de posibles interpretaciones contradictorias, lo que no parece discutible es la incorporación de una serie de valores tales como la libertad, la justicia y la igualdad al ordenamiento jurídico en virtud del artículo 1.1 y del propio 9.3 de

62 S. 30 de octubre de 1976. Batlle en Comentarios al Código Civil, tomo I, Madrid, 1978, p. 56, critica esta actitud del Tribunal Supremo que exige de manera inexplicable, según él, la prueba de la inexistencia de Ley o de costumbre.

63 GonzÁlez Pérez, Jesús, «Los principios generales del derecho y la Constitución» en La Constitución Española y las fuentes del Derecho, Madrid, 1979, vol. II, p. 1.164.

${ }^{64}$ Véase DíEz PicAzo, «Constitución española y fuente del Derecho» en Cívitas, Revista Española de Derecho Administrativo n. ${ }^{\circ}$ 21, pp. 190 y ss., también GonZÁLEZ PéREZ, obra citada en nota anterior, p. 1.166 que analiza la experiencia italiana en el llamado caso alternativo del derecho. 
la Constitución, en definitiva la configura como Estado de derecho65: es más, la propia existencia de la Constitución en un sentido ontológico, como subraya Karl Loewenstein, supone una concepción que acepta la limitación y el control de poder ${ }^{66}$.

El propio Tribunal Constitucional ha resaltado el valor de la justicia como informador del ordenamiento jurídico, de acuerdo con el artículo 1 de la Constitución ${ }^{67}$.

Lucas Verdú ${ }^{68}$ señala como características del estado de derecho:

«Considero que una descripción más amplia de lo que sea el Estado de Derecho, que abarca las observaciones anteriores sería ésta: Cuando un Estado configura, jurídicamente, la organización y ejercicio de los poderes públicos, de manera que los individuos y sus grupos estén protegidos por la existencia previa de normas e instituciones garantizadoras de sus derechos y libertades».

¿Se pueden indicar tales principios como generales del derecho básico del ordenamiento jurídico ${ }^{69}$ ?

El Tribunal Constitucional parece haberlo entendido así. La sentencia de 4 de octubre de $1970^{70}$ señala:

«Cada norma singular no constituye un elemento aislado e incomunicado en el mundo del Derecho, sino que se integra en un ordenamiento jurídico determinado, en cuyo seno, y conforme a los principios generales que lo informan y sustentan, deben resolverse las antinomias y vacíos normativos, reales o aparentes, que de su articulado resulten. Sólo si, en el contexto ordinamental en que se inserta y teniendo en cuenta las reglas de interpretación admisibles en Derecho, el contenido o las omisiones de un texto normativo produjeran confusión o dudas que generarán en sus destinatarios una incertidumbre razonablemente insuperable acerca de la conducta exigible para su cumplimiento o sobre la previsibilidad de sus efectos, podría concluirse que la norma en cuestión infringe el principio de seguridad jurídica».

Y no solamente lo ha entendido así, sino que el Tribunal Constitucional subraya la doble función de los principios generales del derecho ex-artículo 1 del Código Civil que había sido olvidada por el Tribunal Supremo:

65 Véase Garrido Falla, Comentarios a la Constitución, Madrid, 1980, p. 25.

${ }^{66}$ Loewenstein, K., Teoría de la Constitución, Barcelona, 1964, p. 151.

67 Auto 251/84, de 25 de abril J .C. tomo VIII .

68 En Constitución Española de 1978, tomo I, p. 45, Madrid, 1.983.

69 En tal sentido véase BACHOF, Jueces y Constitución, Madrid, 1963, pp. 25 y ss.

70 STC 150/1990, de 4 de octubre (Pleno) BJC nov. de 1990, p. 5 
«Los principios generales del Derecho incluidos en la Constitución tienen carácter informador de todo el ordenamiento jurídico —como afirma el artículo 1.4, del título preliminar del Código Civil- que debe así ser interpretado de acuerdo con los mismos. Pero es también claro que allí donde la oposición entre las leyes anteriores y los principios generales plasmados en la Constitución sea irreductible, tales principios, en cuanto forman parte de la Constitución, participan de la fuerza derogatoria de la misma, como no puede ser de otro modo. El hecho de que nuestra norma fundamental prevea en su artículo 53.2, un sistema especial de tutela de las libertades y derechos - reconocidos entre otrosen el artículo 14, que se refiere al principio de igualdad, no es sino una confirmación de carácter específico del valor aplicativo - y no meramente programático- de los principios generales plasmados en la Constitución.

En conclusión, en los supuestos en que exista una incompatibilidad entre los preceptos impugnados y los principios plasmados en la Constitución, procederá declararlos inconstitucionales y derogados, por ser opuestos a la misma ${ }^{71}$.

También hay que resaltar que el Tribunal Supremo, que anteriormente no había recalcado el principio ordenado del ordenamiento jurídico y de los principios generales del derecho, lo ha retomado a partir de la jurisprudencia citada del Tribunal Constitucional ${ }^{72}$.

Ciertamente tal reconocimiento no es siempre uniforme y parece efectuarlo el Tribunal Supremo a regañadientes, porque en otras ocasiones, y tal vez más numerosas sigue insistiendo en el carácter exclusivamente supletorio de los principios generales del derecho:

«...el fundamento del principio general del derecho alegado aparece claramente reconocido en el art. 1.257 CC, lo que da lugar a que según la doctrina de esta Sala no pueda ser admitido, por cuanto dado el rango jerárquico que les confiere el art. 1.1 CC, solamente pueden ser citados con éxito a falta de normas legales o consuetudinarias ${ }^{73}$ ».

Como puede verse, el Tribunal Constitucional se basa también en el artículo 53.2 de la Constitución para llegar a esa solución; artículo que señala la tutela de las libertades y derechos reconocidos en el artículo 14 y en la sección 1. a. Pero esta constitucionalización de los principios de la justicia no está exenta de riesgos: riesgos que ya los proclamó Hamilton en los primeros tiempos de la independencia de los Estados Unidos:

71 STC 2 de febrero de 1981, RI-1 BJC mayo 1981, p. 7.

72 S. del T.S. de 21 de abril de 1988, Ar. 3.268.

73 S. 12 de mayo de 1992, Ar. 3.920. 
«Estrictamente hablando, el pueblo no abandona nada en este caso, y como lo retiene todo, no necesita reservarse ningún derecho en particular. "Nosotros, el pueblo de los Estados Unidos, con el objeto de asegurar los beneficios de la libertad a nosotros mismos y a nuestros descendientes, estatuimos y sancionamos esta Constitución para los Estados Unidos de América". Aquí tenemos un reconocimiento de los derechos populares superiores a varios volúmenes de esos aforismos que constituyen la distinción principal de las declaraciones de derechos de varios de nuestros Estados, y que sonarían mucho mejor en un tratado de ética que en la constitución de un gobierno, [...]. Voy más lejos y afirmo que las declaraciones de derechos, en el sentido y con la amplitud que se pretenden, no sólo son innecesarias en la Constitución proyectada, sino que resultarían hasta peligrosas. Contendrían varias excepciones a poderes concedidos y por ello mismo proporcionarían un pretexto plausible para reclamar más facultades de las que otorgan. ¿Con qué objeto declarar que no se harán cosas que no se está autorizado a efectuar? Por ejemplo: ¿para qué se afirmaría que la libertad de la prensa no sufrirá menoscabo, si no se confiere el poder de imponerle restricciones? No es que sostenga que una disposición de esa clase atribuiría facultades de reglamentación; pero es evidente que suministraría a los hombres con tendencias usurpadoras una excusa atendible para reclamar ese poder. Podrían argumentar con cierta apariencia de razón que no se debe imputar a la Constitución el absurdo de precaverse contra el abuso de una potestad que no existe y que la disposición que prohíbe limitar la libertad de la prensa autoriza claramente a inferir la intención de dotar al gobierno nacional de la facultad de prescribir normas apropiadas en el caso de dicha libertad. Esto puede servir de ejemplo de los numerosos asideros que se ofrecerían a la doctrina de los poderes de interpretación si se transige con este imprudente celo en favor de las declaraciones de derechos» ${ }^{74}$.

Como agudamente observó Hamilton el refrendar mediante una ley positiva, por muy importante que fuera ésta, ciertos derechos que se suponen son preexistentes al ordenamiento jurídico y connaturales por su existencia al hombre, tiene el peligro de encerrar a éstos dentro de la «jaula de oro» del ordenamiento jurídico positivo y por ello se ha dicho que «lo que es verdaderamente fundamental, por el mero hecho de serlo, nunca puede ser puesto, sino que debe ser simple presupuesto» ${ }^{75}$.

No obstante como el propio Zagrebelsky reconoce ${ }^{76}$ :

74 Hamilton, El Federalista, México, 1943, p. 376.

75 Zagrebelsky, Gustavo: El derecho dúctil, ley, derechos, justicia, Madrid, 1996, p. 9 .

76 Obra citada, p. 115. 
«Se podría incluso decir que las Constituciones reflejan el "orden natural" histórico-concreto de las sociedades políticas secularizadas y pluralistas, en las que, precisamente por ello, no podría proponerse de nuevo un derecho natural con fundamento no teológico ni racionalista».

En definitiva a pesar de los peligros de concretar en unos principios determinados los principios generales de la justicia y del derecho natural, lo que sí puede admitirse es su reconocimiento por la constitución, o por diversas constituciones; siempre que tengamos muy en cuenta que este reconocimiento no supone que la existencia de los mismos se debe al hecho jurídico de su inclusión en el catálogo de derechos constitucionales, ni que tal catálogo sea limitativo de los derechos y, por tanto, sin que quepa argüir que los que no están en la constitución o en el «bill of rights» no existen.

\section{Conclusiones}

De la doctrinal del Tribunal Constitucional puede deducirse que los principios generales del derecho para dicho Tribunal:

a) Son los que contiene la Constitución.

b) Que para ello el Tribunal Constitucional no se para a enumerar cuáles son tales principios, aunque sí subraya el valor superior de la libertad ${ }^{77}$ y que la igualdad es uno de los valores superiores ${ }^{78}$.

c) Que puntualiza que son de aplicación directa.

d Que deben ser informadores del ordenamiento jurídico.

e) Que tienen una virtud derogatoria de las leyes que se opongan a los mismos.

Con tal interpretación los principios generales del derecho quedan realzados, porque no se trata solamente de ser fuente supletoria, sino de ser fuente informadora de la totalidad del ordenamiento jurídico, pudiendo llegar a la derogación de aquellas normas preconstitucionales que se le opongan.

Incluso podíamos hablar de unos principios constitucionales europeos en el ámbito de la Unión Europea y del convenio europeo para la protección de los derechos humanos y libertades fundamentales de 4 de noviembre de 1950, ámbito más genérico y tal vez más impreciso pero no por ello inexistente.

77 STC 132/1989, de 18 de junio, R-I-93, BJC sep. 1989, p. 1.245.

78 STC 216/1991, de 14 de noviembre, RA 1.844/1988, BJC dic. 91, p. 43. 
¿Es ésta la solución? ¿Hemos de decir que los principios generales del derecho son exclusivamente los contenidos en la Constitución; o como máximo los contenidos en la Constitución y en los tratados que forman la Unión Europea y el entramado de instituciones europeas? Estimo que tal concreción no es suficiente y puede de alguna forma cercenar y empobrecer los principios generales del derecho: pero, no obstante, la referencia a los principios de libertad y justicia contenidos en la Constitución como valor informador de la totalidad del ordenamiento jurídico supone un paso adelante sobre la mera aplicación de los principios generales del derecho contenidos en el propio ordenamiento jurídico, a los que anteriormente aludía el Tribunal Supremo.

Ello no significa que la concreción a un ordenamiento jurídico determinado no tenga siempre los peligros de limitación en el espacio y en el tiempo: en el espacio porque donde la Constitución no garantiza esos principios no existe tal módulo de referencia en el tiempo por la misma razón a los períodos históricos en que la normativa básica ha sido diferente, razones que nos hacen abonar el concepto tradicional de los principios generales del derecho fundados en el derecho natural o en la idea de la justicia —más abstracta pero también más universal y menos controvertida - como base del ordenamiento jurídico. 



\title{
LA FUNDACION: SOMERO ANALISIS DE LA LEY 12/1994 DEL PARLAMENTO VASCO
}

\author{
José Manuel Fernández Hierro
}

Sumario: 1. Precedentes. 2. La nueva ley: bases. 3. Constitución. 4. Elementos. 4.1. Fin. 4.2. Patrimonio. 4.3. Funcionamiento. 4.4. Organos. 5. Conclusiones.

\section{Precedentes}

La fundación según Rico Pérez ${ }^{1}$ se puede definir como aquel patrimonio autónomo que, organizado y destinado por el fundador, a la consecución de un fin general permanente y lícito, es administrado sin ánimo de lucro, en forma de empresa por las personas a quienes corresponda su gobierno, conforme a las prescripciones de los estatutos y que, constituida regularmente, gozará de personalidad jurídica.

La fundación que el Derecho Romano no conoció, y que tiene su antecedente y origen en la Edad Media, a través fundamentalmente del Derecho Canónico, se han caracterizado dentro de nuestro ordenamiento jurídico por una pobreza normativa, al menos en cuanto a su regulación genérica, ya que no ha existido durante muchos años, además del contenido del artículo 34 de la Constitución y del artículo 35 del Código Civil, una normativa dispersa fundamentalmente de orden administrativo y dedicada a diferente tipo de fundaciones.

El ámbito anglosajón es aquel en que por distintas circunstancias han florecido más las fundaciones, en algunos casos de una importancia sorprendente, creadas habitualmente por grandes magnates a las que legaban sus fortunas o parte de las mismas, prodigándose durante el presente siglo en Inglaterra y Estados Unidos y creándose en Inglaterra una legislación que las trataba de proteger y favorecer ${ }^{2}$.

1 Las fundaciones en la Constitución española, Toledo, 1982, pp. 54 y ss.

2 Rowntree Trust Act de 1904 y Leverhulme Trust Fund Act de 1925. 
El derecho español hasta la publicación de las leyes de 1994 —y salvo el contenido de alguna ley autonómica- era un sistema formado por la concurrencia de normas muy distintas, la mayoría de ellas administrativas, de la que puede ser significativa la Ley de Beneficiencia de 1849 y formado por un conjunto de normas civiles y administrativas, las cuales se atribuía la administración de la fundación mediante la intervención de distintos departamentos ministeriales.

Como ejemplo puede ponerse el antiguo Reglamento de Fundaciones Culturales que encomienda el protectorado de estas instituciones al Ministerio de Educación y Ciencia.

Se había dicho del derecho anterior a las leyes de 1994, que era un derecho intervenido dentro de un sistema dual de tutela ${ }^{3}$ sometido a la doble tutela de los patronos - o del fundador - y de la Administración Pública y que, además, se caracterizaba por una variedad de supuestos y de regulaciones, señalándose, por ejemplo, que la inscripción administrativa en el registro de fundaciones culturales era constitutiva para las fundaciones de este tipo, mientras que no lo era para fundaciones de otro carácter o entidad.

Pero las sentencias del Tribunal Supremo de 12 de febrero de 1915 y 20 de abril de 1920 establecían que ningún artículo del Código exige para la existencia de una fundación la aprobación del Estado, por lo que tienen personalidad jurídica aún antes de ser reconocidas.

En el derecho preconstitucional se entendía que era característico de la fundación el tener su origen en un acto de constitución otorgado por una persona de derecho privado y que nunca las entidades de derecho público podrían constituir fundaciones ${ }^{4}$.

También se mantiene que la fundación ha de tener interés público, no pudiendo constituirse para fines meramente particulares ${ }^{5}$.

A la legislación ordinaria española en materia de fundaciones privadas de interés público se le ha calificado de «fragmentaria, incompleta, vetusta, confusa, y contradictoria en ocasiones» ${ }^{6}$.

En cualquier caso la regulación preconstitucional no solamente era dispersa, sino también escasa, por lo menos dentro del ordenamiento jurídico civil, e incluso cabría decir que se trata de una figura jurídica

3 Merino Marchán, José F., «Comentario al artículo 34 de la Constitución» en Constitución Española de 1978, tomo III, p. 451.

4 Alfonso de Cossío y CoRral, «Comentario al artículo 35 del Código Civil» en Comentarios al Código Civil y Compilaciones Forales dirigidos por Manuel Albadalejo, tomo I, pp. 838 y ss.

5 Cossío, obra y lugar citado.

6 Merino Marchán, obra citada, p. 454. 
bastante olvidada por la doctrina y que también ha provocado escasas decisiones jurisprudenciales.

Por todo ello se ha visto en el precepto constitucional la posibilidad de actualizar la regulación sobre fundaciones.

\section{La nueva ley: bases}

El 24 de noviembre de 1994 se promulgó la nueva Ley estatal de fundaciones y de incentivos fiscales a la participación privada en actividades de interés general.

Posteriormente se ha promulgado por el Parlamento Vasco de 17 de junio de 1994 la Ley n. ${ }^{\circ}$ 12/1994 que se destina a las fundaciones que desarrollen sus funciones fundamentalmente en el País Vasco, de acuerdo con el artículo 2 de la Ley. Dicha Ley tiene una evidente inspiración en la correspondiente estatal, hasta el punto de que podría entrar dentro del grupo de leyes de Comunidades Autónomas a las que el Tribunal Constitucional ha mirado con recelo por los riesgos que conllevan la reproducción en su ordenamiento de leyes estatales ${ }^{7}$ (aunque es de resaltar que varias de las leyes autonómicas son anteriores a la estatal).

Es más cabría preguntarse que si todas las comunidades autónomas dictan luego leyes de fundaciones ¿cuál es la misión de la precedente Ley estatal? En cualquier caso a dicha Ley de la Comunidad Autónoma del País Vasco van dirigidos estos comentarios.

La nueva ley se basa en la competencia que la Comunidad Autónoma Vasca tiene asumida en materia de fundaciones, en virtud del artículo 10 del Estatuto de Autonomía; y, como queda dicho está destinada a las fundaciones que tengan sus funciones fundamentalmente en el País Vasco, debiendo estar a tales efectos a lo que dispongan los Estatutos o Carta Fundacional, según el artículo 2 de la Ley: en efecto, para que la fundación esté sujeta a la Ley comentada debe tener su domicilio en la Comunidad Autónoma del País Vasco (artículo 7.1.c)).

El artículo 2 hace referencia a los apartados c) y d) del artículo 7.1. los cuales determinan que el domicilio debe encontrarse dentro del País Vasco (apartado c)) y que el órgano de la fundación queda facultado para la determinación de la sede de sus establecimientos o delegaciones, si las hubiere (apartado d).

7 STC 40/81, 26/82 y 162/96. 
Tal remisión del artículo 2 al artículo 7 no es del todo clara, porque significa que una fundación que mantenga su domicilio en el País Vasco aunque tuviera una serie de sucursales importantes fuera del mismo sigue rigiéndose por la Ley comentada; parece que, atendiendo a la competencia territorial de la propia Comunidad Autónoma así como al sentido del artículo 2 lo que debe primar no es el hecho sólo de la domiciliación de la fundación, sino que ésta realice la mayoría de sus actividades o sus actividades más transcendentes dentro del ámbito de la Comunidad Autónoma: lo que sucede es que la determinación de cuales sean las actividades más importantes y transcendentes puede ser una materia conflictiva y no exenta de dificultades.

La Ley comentada, como la estatal del mismo año, cambia el tradicional sistema de inexistencia de normativa de la fundación por otra que aún basándose en la libertad del fundador, paradójicamente regulan y determinan de manera mucho más detallada las características de la fundación, los requisitos que deben de reunir y la forma de su constitución.

Señala Del Campo Arbulo ${ }^{8}$ cómo han caído en saco roto las unánimes exhortaciones de la doctrina jurídica en pro del principio de la voluntad del testador, y tal observación que el referido autor hace referente a la Ley estatal es aplicable, mutatis mutandis, a la Ley promulgada por la Comunidad Autónoma del País Vasco.

De la ley estatal se ha dicho que es claramente intervencionista aplicando un concepto socialdemócrata que hoy en día van abandonando la mayoría de las legislaciones europeas ${ }^{9}$.

De tal tendencia legislativa hay también más muestras dentro del derecho europeo: concretamente de acuerdo con el artículo 18 de la Ley francesa de 23 de julio de $1987^{10}$ la fundación adquiere su capacidad jurídica desde la entrada en vigor del Decreto del Consejo de Estado acordando el reconocimiento de utilidad pública, que, a su vez, puede también retirarla.

Es de resaltar que la Ley vasca es una de las pocas que no contiene una definición de fundación, al revés que la Ley estatal y otras promulgadas por otras comunidades autónomas ${ }^{11}$.

8 Ley de fundaciones, Madrid, 1996, p. 58.

9 De Prada GonzÁlez, José María, «La constitución de las fundaciones» en Las fundaciones, desarrollo reglamentario de la ley, Madrid, 1997, p. 55.

${ }^{10}$ Ley 87-571. También art. 20 de la Ley francesa 20-559 de 4 de julio de 1990.

11 Por ejemplo el artículo 2.1 de la Ley $1 / 82$ de 3 de marzo sobre fundaciones aprobada por el Parlamento Catalán señala:

«Las Fundaciones privadas, constituidas de acuerdo con esta Ley, son personas jurídicas con plena capacidad jurídica y de obrar para cumplir sus finalidades, con las limitaciones que les impongan la misma Ley o sus Estatutos». 
Sí se señala que las fundaciones deben perseguir fines lícitos y de interés general (recogiendo la opinión que ha sido unánime en nuestra doctrina jurídica y que también han reconocido otras normativas en derecho comparado como el artículo $1 .^{\circ}$ del Decreto francés de 13 de junio de 1966) y beneficiar a personas no individualmente determinadas (artículo 3), adoptando una fórmula más acertada que la del legislador estatal, que, en su artículo 2, sigue un criterio enumerativo como si no hubiera sabido encontrar un enunciado de tipo general.

Señalaba Tomás y Valiente ${ }^{12}$ cómo lo contrario del interés particular no es lo público, sino lo general y por tanto la admisión por el artículo 35 de la Constitución de la cláusula de interés general, ampliaba considerablemente el horizonte del Código Civil, sobre esta materia.

Del Campo Arbulo ${ }^{13}$ se pregunta cuál será la dimensión mínima de un colectivo para que pueda reputársele de indeterminado, contestándose que la Ley sólo exige que los beneficios de la fundación se otorgue a colectividades genéricas de personas, sin señalar la cifra mínima de individuos que es susceptible de integrar este colectivo y que, por tanto, puede oscilar entre el cero y el infinito; poniendo el ejemplo del premio a un trabajo científico en materia del tratamiento de SIDA que sólo puede entregarse a una persona, aunque sea inicialmente indeterminada.

En lo que sí sigue la Ley Autónoma a la estatal es en prohibir que se constituyan fundaciones con la finalidad de destinar sus prestaciones a los cónyuges o parientes del fundador hasta el cuarto grado inclusive (artículo 3.2 de la Ley y artículo 2.3 de la Ley estatal).

\section{Constitución}

De acuerdo con el artículo 4 de la Ley, toda persona física o jurídica puede constituir fundaciones; pudiéndose constituir la fundación por actos inter vivos o mortis causa y debiéndose formalizar en ambos casos por escritura pública (artículo 4 de la Ley).

Pero la personalidad jurídica no se otorga por el acto del fundador ni siquiera por el otorgamiento de la escritura pública, sino solamente

Y el artículo 18 de la Ley francesa 87-571 señala:

"La fondation est l'acte par lequel une ou plusieurs personnes physiques ou morales décident l'affectation irrévocable de biens, droits ou ressources à la réalisation d'une oeuvre d'intérêt général et à but non lucratif».

12 «La Constitución española y el derecho de Fundaciones» en Consideraciones sobre el tratamiento jurídico y fiscal de las fundaciones españolas, Bilbao, 1994.

13 Obra citada, p. 68. 
por la inscripción en el Registro de Fundaciones (artículo 5.2 Ley), con lo cual podemos ver en la fundación de la fundación tres fases:

a) El acto inter vivos o mortis causa del fundador.

b) El otorgamiento de la escritura pública que, en el supuesto de actos mortis causa, es lógicamente otorgada por el comisario foral o el albacea testamentario o, en su caso, por los herederos o las personas a quienes corresponde la ejecución del testamento, y

c) La inscripción en el registro de fundaciones.

Requisitos que, por otra parte, son paralelos a los que señalan los artículos 6 y 7 de la Ley estatal de 25 de noviembre de 1994, la cual como señala De Prada ${ }^{14}$ acaba con la interpretación doctrinal y jurisprudencial de que las fundaciones existían desde que se expresaba la voluntad de constituirlas.

En definitiva se exige, con ambas leyes, por primera vez en nuestro ordenamiento jurídico de una forma general, no sólo el acto fundacional sino la escritura pública y la inscripción en el registro específico creado al efecto.

Cabe plantearse si tales requisitos pueden lesionar el contenido del artículo 34 de la Constitución: pero el interrogante debe merecer una respuesta negativa, no sólo por el condicionante del artículo 34.1 del reconocimiento del derecho de fundación «con arreglo a la Ley», sino, también, porque el establecimiento de una escritura pública y la inscripción en un registro específico no parece que viole ni que haga imposible el derecho constitucional de fundación. Ahora bien, lo que si habrá que entender es que los requisitos son limitativos y que no se puede denegar sin motivo justificado la inscripción de una fundación en el registro que sí podría suponer la violación del derecho constitucional contemplado en el artículo 34 de la Constitución Española.

En cuanto al acto fundacional que fuera mortis causa, la forma que lo contenga, deberá ser la apta para producir tales efectos como acto de última voluntad con arreglo a la Ley de Derecho Foral del País Vasco y al Código Civil.

El artículo 5.1.2. ${ }^{\circ}$ de la Ley señala:

«En el acto fundacional mortis causa el fundador podrá otorgar por sí mismo la escritura pública o designar a las personas que hubieren de otorgarla. En caso de que el fundador se hubiese limitado a establecer su voluntad de crear una fundación y disponer de los bienes de la dotación, la escritura pública en la que se contengan los demás requisitos exigidos por esta ley se otorgará por el comisario foral o por el albacea

\footnotetext{
14 Obra citada, p. 81.
} 
testamentario, o, en su defecto, por los herederos o las personas a quienes en derecho corresponda la ejecución del testamento u otra disposición mortis causa, según la legislación civil aplicable».

Lógicamente la referencia efectuada es cuando el fundador no efectúe por sí mismo el otorgamiento de escritura pública, sino solamente el acto mortis causa que dé origen, más adelante, al otorgamiento de la correspondiente escritura.

Los requisitos que debe de contener la escritura de constitución de acuerdo con el artículo 6 de la Ley (similar al 8 de la Ley estatal) son:

«a) Las circunstancias que acrediten la personalidad de los fundadores, sean personas físicas o jurídicas, y determinen su capacidad para constituir una fundación, con mención específica de su nacionalidad, domicilio, vecindad civil y, en su caso, régimen económico matrimonial.

b) La voluntad de constituir una fundación con sujeción a las disposiciones de esta ley.

c) La aportación patrimonial inicial de la fundación, con descripción y naturaleza de los bienes y derechos que la integran, su titularidad, sus cargas y el título de aportación, y demás elementos exigidos de acuerdo con lo dispuesto en el artículo 9.

d) Los Estatutos fundacionales, que deberán contener los extremos señalados en el artículo 7.1.

e) La identificación de las personas que integren el órgano de gobierno y, en su caso, la aceptación del cargo si se realiza en el acto fundacional.

f) El fundador o fundadores podrán dar a la escritura pública el carácter de carta fundacional, con el fin de que puedan adherirse otras personas con el carácter de fundadores. En tal caso, se fijará el plazo durante el cual haya de formularse tal adhesión».

Hay que resaltar el trascendental requisito de la aportación patrimonial que es el que en definitiva da origen a la fundación y sobre el que volveré más adelante.

¿Qué sucede si no se reúnen tales requisitos? Poniendo en consonancia el artículo 6 con el 5.3 que señala la falta de inscripción si no se reúnen tales requisitos, habría que mantener que deberán subsanarse en el plazo que para ello se le otorgue a las personas encargadas de la inscripción de la fundación, lo cual debería hacerse, una vez cumplidos los requisitos previos en su caso, mediante el otorgamiento de una escritura complementaria y la solicitud de su inscripción definitiva en el Registro de Fundaciones.

Evidentemente la denegación de la inscripción no puede ser inmotivada, no sólo porque así lo recoge la Ley, sino porque, como queda di- 
cho, tal denegación inmotivada violaría el contenido del derecho constitucional de fundación.

Los fundadores pueden ser no sólo las personas físicas, sino también las jurídicas e incluso las públicas, y las públicas pueden ser solas o con la participación de otras entidades o particulares, contra lo que ha sido tradicional dentro de nuestro ordenamiento jurídico.

\section{Elementos}

Los elementos que tradicionalmente se han entendido que componen una fundación son, por una parte, un fin, por otra, un patrimonio y, finalmente, una personalidad jurídica con un órgano de actuación.

\subsection{Fin}

Como ha quedado expuesto, los fines de la fundación pueden ser cualquiera, siempre que sean lícitos y de interés general; no pudiendo tampoco beneficiar a personas individualmente determinadas ni tampoco a los cónyuges o parientes del fundador hasta el cuarto grado inclusive (artículo 3).

En cuanto a la ilicitud de los fines habrá que estar a lo que señala el Código Civil y el resto de la legislación, debiéndose presumir en cualquier caso la licitud de los mismos.

Respecto a los fundadores se ha señalado que cualquier persona física o jurídica, privada o pública, puede constituir fundaciones, tanto por actos inter vivos como por actos mortis causa.

\subsection{Patrimonio}

¿Qué sucede con el patrimonio? En el artículo 9 se prevén una serie de normas:

a) Que puede ser de bienes o derechos de cualquier tipo.

b) Que debe constar en la escritura fundacional.

c) Que la dotación puede ser en forma de acto único o sucesiva.

d) Que en el supuesto de aportación sucesiva el plazo para completar la aportación inicial como máximo será de cinco años desde la fecha de la escritura de constitución y la aportación mínima del $30 \%$ ampliable excepcionalmente cuando se trate de aportación de derechos. 
La naturaleza de la aportación es señalada por la Ley estatal, según indica Del Campo Arbulo, siguiendo a Gomeza Ozamiz ${ }^{15}$, de manera analógica a las participaciones en una sociedad mercantil, lo cual no parece que sea el tratamiento más adecuado para una fundación; y tal observación también es aplicable a la Ley vasca comentada.

Por la Ley se señala que debe ser la aportación adecuada y suficiente para el cumplimiento de los fines fundacionales, pero lo que no se indica es que es lo que se entiende por adecuado y suficiente y, por supuesto, no se prevé ninguna fórmula de adecuación sucesiva del capital a los fines de la misma, lo cual ciertamente es complejo pero que suele ser el problema real de muchas fundaciones cuyos medios son adecuados para el fin inicial, pero que luego, por la desrealización de éstos, la inflación o diversas causas se quedan cortos y desfasados.

De los actos de disposición o gravamen sobre los bienes o derechos que forman parte del patrimonio o que están directamente adscritos a sus fines debe darse cuenta inmediata al protectorado según el artículo 22-1 de la Ley, y también inscribirse en el Registro de Fundaciones. La Ley no indica qué sucede si el Protectorado, a posteriori, no aprueba la actuación de los órganos de la fundación; pero como la Ley nada dice de posibles nulidades aunque sí de una hipotética acción de responsabilidad, habrá que concluir que no cabe la nulidad (por este solo hecho y sin perjuicio de que la nulidad pueda devenir de las causas genéricas contenidas en el ordenamiento civil) y sí solamente la petición de responsabilidad a los órganos de la fundación.

\subsection{Funcionamiento}

En cuanto al funcionamiento la Ley prevé como inexcusable (lo que en el derecho anterior no lo era) la existencia de unos estatutos y la inclusión en ellos de una serie de extremos que recoge el artículo 7.1 y que son:

«a) La denominación de la entidad, en la que deberá figurar la palabra "fundación" o "fundazioa" o "iraskundea", que no podrá coincidir con ninguna otra previamente inscrita en el Registro de Fundaciones.

b) Los fines fundacionales.

c) El domicilio de la fundación, que deberá radicar en la Comunidad Autónoma del País Vasco.

d) El órgano de la fundación facultado para la determinación de las sedes de sus establecimientos o delegaciones, si las hubiere.

15 Obra citada, p. 145. 
e) El ámbito territorial en que haya de desarrollar principalmente sus actividades.

f) Las reglas básicas para la aplicación de los recursos al cumplimiento de los fines fundacionales y para la determinación de los beneficiarios.

g) El órgano de gobierno y representación con expresión de su composición, reglas para la designación y sustitución de sus miembros, causas de su cese, sus atribuciones y la forma de deliberar y adoptar acuerdos.

h) La regulación del régimen jurídico de los colaboradores de la fundación, si los hubiere, así como su participación en los órganos de gobierno de la misma».

El artículo 7 en cuanto se refiere al contenido de los estatutos es paralelo - aun cuando no igual- al artículo 9 de la Ley estatal, añadiendo únicamente la indicación de que los estatutos pueden contener la regulación del régimen jurídico de los colaboradores de la fundación, si los hubiere, así como su participación en los órganos del gobierno de la misma (artículo 7.1.h)).

Hay que entender que la falta de cumplimiento de tales requisitos como la falta de cumplimiento de los que para la escritura de constitución señala el artículo 6 no da origen a la nulidad de los mismos, sino a que sean requeridos los fundadores para la cumplimentación a posteriori: si bien en esta hipótesis tal cumplimentación sería más compleja ya que requeriría primero la subsanación de los estatutos, el otorgamiento de escritura complementaria y la inscripción de los mismos en el Registro de Fundaciones.

Además, de acuerdo con el artículo 7.3 la manifestación de la voluntad del fundador señalada en los estatutos que sea contraria a la presente Ley pero no afecte a la validez constitutiva de aquélla, se tendrá por no puesta cuando haya transcurrido el plazo para subsanarlo sin llevarse a efecto; con lo cual si no se ha subsanado la falta o defecto en el plazo concecido al efecto puede haber una doble consecuencia:

a) Si la manifestación de la voluntad del fundador afecta a la validez constitutiva de la fundación se produciría la nulidad de la misma.

b) En caso contrario, esto es, si tal manifestación no afecta a la validez de la fundación se tendría por no puesta.

Notemos además que tal manifestación legal hace referencia a la voluntad del fundador, que fuera contraria a la presente ley y no sólo a los requisitos que señala el artículo 7 en cuanto a los estatutos y el 6 respecto de la escritura de constitución; porque bien pudiera dar el caso 
de que cumpliéndose los requisitos de los artículos 6 y 7, hubiera alguna manifestación de voluntad contraria al contenido de la Ley.

¿Cuándo debe entenderse que afecta a la validez constitutiva de la fundación? La Ley nada dice al respecto y habría que entender que es cuando tal manifestación está en contraposición a los fines básicos de la Ley, para lo que habría que efectuar la exégesis de la cláusula de que se trate y su adecuación o no a las normas de orden público contenidas en la Ley que, de la propia manifestación legal contenida en el artículo 7.3 , se deduce que no son todas.

Es más la calificación del registro de asociaciones que deberá ser fundada, deberá tenerse en cuenta por los fundadores o por los comisarios forales o albaceas encargados al efecto por el testador, indicando expresamente el artículo 7.3.2. ${ }^{\circ}$ que:

«En el supuesto de constitución mortis causa el fundador podrá otorgar al comisario foral o a los albaceas facultades para ponderar, siempre de conformidad con el espíritu fundacional, las consecuencias de la calificación registral».

Es de resaltar también el paralelo de los requisitos en cuanto a constitución y en cuanto a estatutos de la Ley vasca de fundaciones con la Ley estatal en sus artículos 8 y 9 y concretamente la manifestación de invalidez relativa en el supuesto de contradicción de los estatutos con la Ley, con el contenido del artículo 9.2 de la Ley esta$\operatorname{tal}^{16}$.

\subsection{Organos}

De acuerdo con la nueva Ley —al igual que sucede con la estatalque sigue en este punto la línea tradicional, puede señalarse la existencia de un patronato constituido por el órgano de dirección y, además, una supervisión administrativa; si bien la Ley aprobada por el Parlamento Vasco elude, al revés de la estatal, la tradicional terminología de patronato y patronos.

La Ley marca un sistema de gestión, control y funcionamiento doble: por un lado está el órgano designado por el fundador que es el órgano rector y por otro el patronato u organismo administrativo.

El órgano de gobierno de la fundación deberá ser colegiado a no ser que el fundador señale otra cosa, estando compuesto de tres per-

16 Obsérvese también los requisitos que el Registro de Fundaciones de Navarra debe exigir con arreglo al Decreto Foral de 11 de noviembre de 1996, n. ${ }^{\circ}$ 613/96. 
sonas como mínimo y dirigiendo su seno un presidente (artículo 10.3) y pudiendo entrar dentro del órgano de la fundación las personas jurídicas siendo lógicamente representadas por una persona física.

La Ley vasca no contiene, adecuadamente en mi opinión, la prohibición del artículo 13 de la Ley estatal de que los patronos deben ejercer su cargo gratuitamente, mandamiento que puede no compaginarse ni con la voluntad del fundador ni con las tareas de dirección de una fundación compleja; señalando, eso sí, las obligaciones de administrar correctamente los bienes y derechos y servir al cargo con la diligencia de un representante legal (artículo 13).

En la Ley no se indica nada sobre la sustitución de los miembros de la fundación, dejándolo al arbitrio de los estatutos que sí deben contener la determinación de la forma de sustitución (artículo $7 \mathrm{~g}$ )). Y este es uno de los problemas claves que, de hecho, en el funcionamiento de las fundaciones ha tenido difícil solución: no olvidemos que en las fundaciones no hay una junta general de socios ni de asociados y que por lo tanto habitualmente, al menos antes de las leyes de 1992 no se preveía en los estatutos un órgano superior al patronato que fuera ante el cual éste rindiera cuentas, y, que además, tuviera capacidad para sustituirlo.

El buscar una solución a este problema no es, ciertamente, nada fácil, pero la nueva Ley no señala incluso qué sucede si la regulación de los estatutos sobre este particular es insuficiente, con lo cual se produce una laguna importante, lo mismo que sucede con la homónima estatal. Como ejemplo el Decreto 160/82 por el que se aprueba la instrucción para la organización y funcionamiento para el protectorado de la Generalitat sobre las Fundaciones privadas de Cataluña señala la competencia de la Unitat de Registre para la tramitación de los expedientes para suplir a los fundadores, y a sus representantes y al patronato, y se asimila a la falta total del patronato su prolongada inactividad (artículo 27).

Ciertamente se prevé una actuación del protectorado, realizando la gestión provisional de la fundación, de acuerdo con el artículo 38, pero tal gestión sería en las hipótesis de grave irregularidad económica, y no de abandono de los miembros del protectorado o de inexistencia de este órgano.

Los mecanismos para efectuar tal sustitución eran, la mayoría de las veces insuficientes; y, la Ley comentada, como la correspondiente estatal (en su artículo 16 del que es casi copia el correlativo de la Ley vasca), no resuelve el problema. Así señala como causa suficiente para el cese de los patronos de una fundación el transcurso del tiempo de su 
mandato (apartado f) de ambas leyes) si fuera nombrado por tiempo determinado; pero no se indica, dejándolo solamente al arbitrio de los estatutos, quien designará a los nuevos patronos; siendo notable que una Ley claramente intervencionista deje al total arbitrio de los estatutos un extremo tan transcendental para el funcionamiento de la fundación como éste.

Se señala la posibilidad de renuncia (apartado h) de la Ley y g) de la estatal) pero tampoco se dice en tal hipótesis quién lo sustituirá y de que forma se designará a los sustitutos.

Se prevé la posibilidad de una acción de responsabilidad en paralelo a las acciones que contiene las leyes de sociedades anónimas y sociedades limitadas, pero tales acciones se reservan exclusivamente al protectorado del órgano administrativo (artículo 15 en relación al 36) y no a los miembros de la fundación.

El protectorado es precisamente una pieza clave de la fundación, siendo el órgano administrativo, de asesoramiento, apoyo técnico y control de las fundaciones (artículo 36) y que corresponde a la Administración General de la Comunidad Autónoma del País Vasco a través del Departamento de Justicia (artículo 36.3); precisamente uno de los reproches que puede efectuarse a la Ley — también en total consonancia con la estatal- es la estricta fiscalización por parte de la administración de las actuaciones de la fundación, ya que el órgano de gobierno, según el artículo 26 deberá elaborar anualmente, además de un presupuesto de ingresos y gastos, el inventario, balance de situación y la cuenta de resultados en los que se reflejará la situación patrimonial, económica y financiera de la fundación, y una memoria de las actividades realizadas durante el ejercicio económico en las cuales deberá comprenderse el cuadro de financiación y cualquier alteración patrimonial e incluso de su órgano de gobierno o de dirección (artículo 26.1) y además liquidación del presupuesto de gastos e ingresos del ejercicio anterior (artículo 27 c)) . Todos los documentos mencionados deberán ser depositados en el registro de fundaciones (art. 27.2) además de la $\mathrm{Au}$ ditoria de cuentas externas cuando se trate de fundaciones de relevancia económica (art. 28.2).

Como queda señalado es necesaria la comunicación al protectorado, de acuerdo con el artículo 22 de la Ley:

a) De los actos de disposición o gravamen sobre los bienes o derechos que formen parte de la dotación patrimonial.

b) De los actos de disposición o gravamen sobre los bienes o derechos que están adscritos al cumplimiento de los fines de la fundación. 
c) Sobre los actos de disposición o gravamen que, aun sin estar adscritos a los fines de la fundación sean superiores al $20 \%$ del activo de ésta, y

d) Para someter a arbitraje o transación cualesquiera de los bienes antes indicados.

La aportación de tal cúmulo de documentación hace, sin más, inviables las pequeñas fundaciones; quedando al intérprete la duda de si van a valer para algo positivo o van a archivarse en una oficina burocrática.

La posibilidad de modificación de los estatutos de la fundación se admite por el artículo 31 pudiéndolo hacer el órgano de gobierno de la misma, siempre que se respete el fin fundacional y no exista prohibición del fundador, recogiendo el artículo 33 las causas de extinción de la fundación y siendo la liquidación efectuada por el órgano de gobierno de la misma bajo el control del patronato (artículo 35).

\section{Conclusiones}

Esta breve visión de la nueva legislación nos da un panorama de luces y sombras de la misma:

1. ${ }^{\circ}$ En el aspecto positivo cabe señalar la unificación de la normativa de la fundación que estaba dispersa antes de la ley comentada y de la homóloga estatal.

También cabe señalar como aspecto positivo, la posibilidad de modificación ulterior de la fundación.

También es remarcable la posibilidad de que el acto de dotación se haga de manera más elástica, al poderse efectuar de forma sucesiva e integrada por la aportación de cualquier clase de bienes y derechos.

2. ${ }^{\circ}$ En cambio en la parte negativa de la nueva legislación habría que apuntar:

a) El no haber regulado la forma de sustitución del órgano de dirección que suele ser el escollo con que, a lo largo de su vida, han tropezado muchas fundaciones.

b) El haber optado por la exigencia de un capital fundacional inicial sin haber previsto su ulterior adecuación a los fines de la misma. 
c) El exigir unos trámites demasiado engorrosos y complejos para fundaciones de pequeña importancia, dificultando en la práctica su existencia.

d) Y en definitiva optar por un modelo de claro intervencionismo de la administración con lo que ello conlleva.

e) El crear una doble vía jurisdiccional ya que contra el dictamen del órgano de control cabe el recurso contencioso administrativo (artículo 39) mientras que en otros casos, debe entenderse que el órgano competente es el juez civil, y así se deduce del contenido del artículo 38 de la Ley.

He tratado en estas breves notas de hacer un bosquejo de urgencia de las novedades que la nueva legislación introduce, que no sólo deberán ser objeto de un estudio ulterior, sino que además la praxis jurídica ulterior se encargará de contrastar y pulir. 



\title{
UNAMUNO Y LA REVISTA FRANCESA MONDE (1928-1934) \\ (Artículos no recogidos en las Obras Completas)
}

\author{
Manuel M. ${ }^{a}$ Urrutia
}

Es un deber de todo buen unamuniano contribuir a la futura - ¿la veremos algún día? - edición crítica de las Obras Completas de Miguel de Unamuno. Anunciada como proyecto por la Universidad de Salamanca en 1991, se trata de una ardua labor condicionada por su enorme envergadura. Y nos referimos, sobre todo, a la necesaria recopilación — icronológica! - de los más de dos mil artículos de Unamuno, aún no recogidos en las Obras Completas publicadas por la editorial Escelicer entre 1966 y 1971 (unos 1.150 ya publicados en libros y artículos desde 1971; y, al menos, otros mil dispersos aquí y allá). Tarea en la que nos tememos no se va a avanzar un ápice con la publicación de unas nuevas presuntas Obras Completas comenzadas a editarse en $1995^{1}$.

Presentamos aquí nuestra modestísima aportación a dicha tarea, que necesariamente ha de ser labor de muchos investigadores. Se trata de la colaboración de Miguel de Unamuno, durante el último tercio de su destierro voluntario (1928-1929), en la revista parisina Monde.

Fue posiblemente Paulette Moracchini, en un trabajo que no llegó a publicarse, la primera que aludió a estas y otras colaboraciones del ilustre exiliado en la prensa francesa ${ }^{2}$.

1 Miguel de Unamuno, Obras Completas, vols. I y II, Madrid, Turner, 1995.

2 Paulette Moracchini, Unamuno pendant son exil en France 1924-1930, Faculté de Lettres de Paris, Institut d'Etudes Hispaniques, juin 1955. Trabajo para la obtención del diplôme d'Etudes Supérieures, y dirigido por el unamuniano Charles V. Aubrun. Quizás fuera el propio Aubrun quien depositó el ejemplar mecanografiado, y corregido, que se conserva en la Casa Museo Unamuno de Salamanca (a partir de ahora CMU). Véanse las páginas 67-70 y 88, donde señala correctamente — como hemos podido corroborar al revisar la publicación- las colaboraciones de Unamuno. 
Años después, Emilio Salcedo, en su Vida de don Miguel daba cuenta de la carta en la que Henri Barbusse propuso a Unamuno formar parte del Consejo de Redacción de la futura revista, así como de la aceptación y colaboración posterior de éste ${ }^{3}$.

En efecto, con fecha del 19 de febrero de 1928, Henri Barbusse, el futuro director, le escribe una carta pidiéndole que apoyara con su nombre la publicación y aceptara colaborar en ella. Que ya ha obtenido la colaboración de «todos los intelectuales notables de izquierda del mundo entero» (entre ellos R. Rolland, M. Gorki, H.G. Wells, R. Tagore, B. Russell, A. Einstein, Lunatcharsky, Stefan Zweig etc.). Todo ello tras haberle informado de cual iba a ser el espíritu de la revista.

Mon cher et éminent confrère,

Je vais lancer au mois d'avril une revue de grande information littéraire, artistique, scientifique, économique et sociale intitulé Monde.

C'est là un effort important que je tente pour donner l'essor à la cause de la justice et de l'emancipation humaine en m'adressant au grand public.

Il ne s'agit pas d'une revue politique: Nous ne sommes à Monde à la remorque d'aucun parti et le journal est absolument indépendant. Nous ne ferons pas du reste de polémique politique propement dite. Nous n'y emploierons pas un ton virulent ni violent, nous resterons dans le domaine des idées, et nous défendrons les grands principes de la démocratie avec sérénité, et je pense, avec autoritét.

Unamuno no tardaría en aceptar. El 26 de marzo, Barbusse, en una nueva carta, ésta en castellano, le confiesa estar sumamente contento por querer «ayudar a nosotros con su autoridad universal». Y aún el 7 de mayo le pregunta si tendría inconveniente en que su nombre figurara en el Comité de Dirección, junto al de A. Einstein, M. Gorki, Upton Sinclair, Manuel Ugarte, León Bazalgette y León Werth ${ }^{5}$.

3 Emilio SAlcedo, Vida de don Miguel, Salamanca, Anaya, 1970 (2. a ed. corregida), p. 308. Henry Barbusse, periodista y escritor, nació en 1873. Participó como voluntario en la $1^{\text {a }}$ guerra mundial, experiencia que cambiaría su vida y le convertiría en un antimilitarista convencido. Dura prueba que sería reflejada con todo realismo en Le Feu (París, 1916), que obtendría el premio Goncourt. Sus ideales humanitarios internacionalistas le llevarían a simpatizar con el comunismo. En 1932 organizó el Primer Congreso Mundial contra la Guerra y el Fascismo. Murió mientras se encontraba de viaje en Moscú, en 1935.

${ }^{4}$ Las cartas de H. Barbusse a Unamuno (entre el 19.02.1928 y el 16.06.1934) se conservan en la CMU $\left(\mathrm{B}_{1} / 72\right)$.

5 Tanto Manuel Ugarte como León Bazalgette eran viejos conocidos de Unamuno, al menos por correspondencia, pues con ambos se carteaba desde tiempo atrás. En la CMU se guardan las cartas de Ugarte (entre el 9.07.1900 y el 21.07.1920; $\mathrm{U}_{6}$ a $\mathrm{U}_{8}$ ) y de Bazalgette (entre el 8.07.1903 y el 13.10.1925; $\mathrm{B}_{3} / 1$ ) enviadas a don Miguel. Unamuno había puesto 
Por fin, el sábado 9 de junio de 1928 saldría el primer número de MONDE (HEBDOMADAIRE D'INFORMATION LITTERAIRE, ARTISTIQUE, SCIENTIFIQUE, ECONOMIQUE ET SOCIALE), con Henri Barbusse como director, y un Comité de Dirección al que hay que añadir los nombres de $\mathrm{M}$. Morhardt y Unamuno a los ya citados. La revista, de periodicidad semanal, y que constaría la mayoría de las veces de 16 páginas, se editó hasta principios de 1934.

La colaboración de Unamuno se circunscribe a finales de 1928 y la primera mitad de 1929, coincidiendo con su exilio en Hendaya, si bien su nombre continuó apareciendo en la nómina del Comité de Dirección.

Conviene reseñar además, antes de presentar los artículos y seguir alguna de sus vicisitudes, que el 27 de octubre de 1928 apareció una Entretien avec Unamuno, fechada en Hendaya en 1928, y firmada por Bogdan Raditsa ${ }^{6}$.

Tras dejar clara su repugnancia a la dictadura ${ }^{7}$, y frente a todos aquellos —enfermedad de la época- que anteponen el orden a la justicia, dirá Unamuno:

Définir l'Occident: la réalisation de l'ordre, est faux. Toutes les discussions à propos de l'esprit européen sont oiseuses lorsqu'elles aboutissent à dire que l'ordre est un élément spécifiquement européen et latin, élément menacé que l'on devrait conserver et sauver... Goethe, occidental latinisé, a dit: «Il est nécessaire de sacrifier la justice à l'ordre». Mais mois je dis: Mieux vaut justice sans ordre qu'ordre sans justice. Mieux vaut la lutte, le désordre que l'injustice, car l'ordre sans la justice, c'est la tyrannie... Ce que nous devons rechercher actuellement, c'est la justice, et la justice c'est la vie même... ${ }^{8}$

prólogo al primer libro literario de Manuel Ugarte: Paisajes parisienses, París, Garnier, 1903; en Salamanca, a julio de 1901 (véanse las Obras Completas, Madrid, Escelicer, 1966-71, vol. VIII, pp. 910-915). Ugarte, cuyo abuelo era vizcaíno, fue corresponsal en París de El Tiempo y La Nación, ambos de Buenos Aires.

6 Bogdan RADITSA, «Entretien avec Unamuno», Monde, n. ${ }^{\circ} 21,27$ octubre 1928, p. 5. Conversación que el autor glosaría, junto con otros encuentros que tuvo con Unamuno, en un artículo de 1959: Bogdan RadiTsA, «Mis encuentros con Unamuno», Cuadernos del Congreso por la Libertad de la Cultura, París, n. ${ }^{\circ}$ 34, enero-febrero 1959, pp. 45-56.

7 No vamos a referirnos aquí al pensamiento político de Unamuno, pues ya lo hemos hecho en toda su extensión en otro lugar: Manuel M. ${ }^{a}$ URRUTIA, Evolución del pensamiento político de Unamuno, Bilbao, Universidad de Deusto, 1997. Y concretamente, en lo referente al período del exilio en el que nos situamos: «El destierro (1924-1931)», Cuadernos de la Cátedra Miguel de Unamuno, Ediciones Universidad de Salamanca, n. ${ }^{\circ} \mathrm{XXX}$, 1995, pp. 61-89.

8 Bogdan RAdiTsA, «Entretien avec Unamuno», Monde, 27-10-28, p. 5. 
Rechazando el nacionalismo estrecho que está en la base de las crecientes dictaduras de la época, y defendiendo el universalismo, muy en consonancia, por otro lado, con el sentido profundamente internacionalista de la revista.

Il y a des nations, dit-il, qui ne peuvent pas se conduire elles-mêmes et qui sont livrées à la merci de quelques aventuriers et de délinquants, conscients des crimes qu'ils commettent. La Société des Nations aurait le devoir d'intervenir, et devrait aider ces peuples à se libérer de leur joug et à conquérir leurs libertés...

Dans certains pays, les nationalismes détruisent tous sentiments d'humanité et s'opposent à la fraternité commune... (...).

Mais ce qui est intéressant pour aujourd'hui et pour l'avenir, conclut Unamuno, c'est l'esprit de l'humanité et de l'universalité, c'est la conscience commune vers laquelle le monde s'achemine, la conscience de l'internationalisme dans lequel l'Espagne, elle aussi, doit prendre la place qui l'attend 9 .

Las colaboraciones de Unamuno son las siguientes:

1. 8 septembre 1928. «La littèrature prolètarienne».

2. 19 janvier 1929. Le règne du Bourreau.

3. 26 janvier 1929. Hommage à Bazalgette.

4. 23 mars 1929. Contre le fascisme.

5. 18 mai 1929. Appel aux pères espagnols.

6. 8 juin 1929. Connaissez-vous les uns les autres.

1. «La littèrature prolètarienne» se trata de la respuesta a una encuesta que había sido lanzada por la revista a partir del n. 3 (23 juin), y que dado el número y la calidad de muchos de sus corresponsales, es un documento único. El propio Barbusse plantearía a Unamuno, por carta del 26 de julio, la citada encuesta. La respuesta de Unamuno se publicó a principios de setiembre.

Es la única de las colaboraciones que está recogida en las Obras Completas ${ }^{10}$.

9 Ibidem.

10 Miguel de Unamuno, «¿Existe una literatura proletaria?», OC, vol. IX, pp. 1.2071.209. Bajo este título se nos presentan las dos preguntas de la encuesta de Monde sobre dicho tema, si bien se señala que la contestación fue publicada en Amauta, Lima, en octubre de 1928, de donde al parecer fue tomada. 


\section{Miguel de Unamuno: ${ }^{11}$}

Je ne crois pas qu'il y ait quelque manifestation de l'esprit humain, comme la production artistique et littéraire, qui soit un phénomène purement individuel, ni, non plus, purement social. Un individu humain, conscient, sans société, est aussi impossible qu'une société sans individus, ce que les Anglais appellent un touism. L'individu par lui-même est, sans doute, un produit social, mais la société humaine, à son tour, n'est-elle pas un produit individuel? Et pour ce qui est de la littérature et de l'art, une masse humaine, un groupe d'hommes, est incapable de créer une chanson, un air de musique, une idylle. Je ne crois pas à l'art populaire. Ce que fait le peuple, c'est adopter ou repousser ce qu'un individu lui a donné.

La production artistique et littéraire reflète, sans doute, les grands courants qui déterminent l'évolution économique et sociale de l'humanité, mais reflète également, et mieux, les éternels désirs de l'âme individuelle, le désir de vérité, le désir de rêve consolateur, le désir d'amour et le désir d'inmortalité. Il reflète les aspirations de l'homme en tant qu'homme, en tant qu'individu humain, et ces aspirations, communes au riche et au pauvre, au maître et à l'esclave, au grand et au petit, sont les plus universelles car il n'y rien de plus universel que l'individuel. Les poètes qui vivent le plus dans la conscience des peuples et du genre humain sont ceux qui mirent le mieux à nu, à la lumière du soleil et à l'air qui chante entre les feuilles des arbres son prope coeur; et en disant «Ecce Homo! C'est moi!» ils dirent à chacun des hommes qui les écoutaient: «Tú est ainsi!». Et celui qui les entend se reconnaît lui-même et se dit: «C'est moi!». Ce qui fait que ce qu'on appelle souvent l'égoüsme, d'ego, moi, pourrait s'appeler tuisme, de $t u$, toi. Le véritable poète en s'adressant à la masse mais à chacun d'eux.

Si je croix à l'existence d'une littérature et d'un art qui expriment toutes les aspirations de la classe ouvrière? Les aspirations intimes, profondes, éternellement humaines de chaque homme ouvrier sont les mêmes que celles de n'importe quel autre homme qui a des aspirations humaines. L'ouvrier devient amoureux comme celui qu'on appelle le bourgeois, comme lui il a des enfants, comme lui il souffre lorsqu'il a une personne chère qui meurt, comme lui il craint ou souhaite la mort, comme lui il se préoccupe de la fin de la vie, comme lui il tressaille devant le mystère tragique du destin. Et ces aspirations ont fait l'art et la littérature dont le but, comme celui de la religion, est de consoler l'homme d'être né pour mourir.

Dans les questions que l'on m'adresse, ne figure pas expressément l'expression «littérature prolétarienne». J'aurais du mal de la définir. Plus je lis de livres de sociologie et d'économie politique, moins je comprends ce que veut dire le prolétariat. Si je n'ai pas rencontré de phénomène humain purement individuel ni purement social, je n'ai pas trouvé d'homme qui soit purement prolétaire ni aucun qui ait quelque chose de ce genre. Je crois peu aux classes el

11 Monde, n. ${ }^{\circ}$ 14, 8 septiembre 1928, p. 5. Unamuno escribía sus colaboraciones en castellano y eran traducidas para su publicación. Respetamos por ello los escritos tal y como fueron presentados en la revista, pues una nueva retraducción no tendría sentido, al alejar aún más el texto del manuscrito original. 
aux castes. De même que je crois que chacun porte en soi le tyran et l'esclave, le bourreau et la victime.

Ce que j'a pu observer, c'est que ceux que nous appelons, avec plus ou moins de raison, les prolétaires, ce que l'on écrit pour eux, en tant que prolétaires, ne les intéresse pas davantage que ce que les adultes font pour les enfants, en se mettant à balbutier pour être mieux compris, ce qui fait rire les véritables enfants.

La vie intime de chaque grand homme, qui a été vraiment grand, même si c'est un ermite ou un tyran - il y en a eu de grands par l'esprit- intéresse davantage, avec plus d'émotion esthétique, un ouvrier que n'importe quelle tartine sur la question sociale. Et si le théâtre que nous pourrions appeler socialiste a si peu de durée, c'est parce qu'il n'intéresse pas les socialistes, même ceux qui lisent Marx. Et ce n'est pas que l'on n'aille pas au théâtre pour apprendre, mais on y va pour y apprendre à sentir, y apprendre, surtout, à se sentir homme. Et on ne se sent homme que devant Othello, Hamlet, le roi Lear, le Cid, Phèdre, Don Juan, Tartuffe, Napoléon, Philippe II, etc.

Même en supposant que l'histoire soit le jeu de la lutte de classes, l'art, la littérature, la poèsie sont au-dessus —ou si l'on veut, au-dessous- de cette lutte et unissent les combattants dans la fraternité humaine. Une oeuvre d'art que vous appelez bourgeoise, émotionnera et intéressera ceux que vous appelez polétaires si c'est une bonne oeuvre d'art, et une oeuvre d'art que vous appelez prolétaire émotionnera et intéressera ceux que vous appelez bourgeois si c'est une bonne oeuvre d'art et leur appendra aux uns et aux autres à être des hommes. Et être des hommes, c'est vivre en fonction du destin final de l'humanité.

Miguel de Unamuno (autógrafo)

Hendaye, 8 août 1928

2. El primer artículo como tal, escrito expresamente para Monde, aparecería en enero de 1929.

\section{Le règne du bourreau ${ }^{12}$}

Il me semble que «Monde» remplit en tous points sa mission qui est d'éveiller, de maintenir et d'accroître une conscience mondiale, humaine, en France et au dehors. Une conscience «mondiale» ce qui ne signifie pas internationale mais plutôt supernationale et interpopulaire. Car il y a une Internationale des nationalismes qui vient toujours à la rescousse du fascisme, lequel, en réalité, n'est pas une doctrine mais bien la «barbarie —que l'on me permette ici un jeu de mots d'hellèniste- démiocratique». «Demos» en grec signifie «peuple» et «démios», littéralement «populaire», était le fonctionnaire populaire d'un peuple rongé par l'envie (à l'exception des esclaves), c'est-à-dire:

12 Monde, n. ${ }^{\circ} 33,19$ janvier 1929, p. 3 
le borreau. La «démiocratie» est donc la «bourreaucratie», régime de tous les impérialismes capitalistes; c'est la suprématie du pouvoir exécuteur, non exécutif. Le juge s'y voit subordonné au bourreau. Et le bourreau est aussi bien la police que le gendarme ou le général.

J'ai toujours considéré comme la plus grande marque de génie du Comte Joseph de Maistre, ce patriarche de l'ultramontanisme, la défense et l'apologie du bourreau faites dans ses «Soirées de Saint-Pétersbourg» texte le plus parfait du système inquisitorial. Le bourreau bien plus que le roi est la tête de ce que l'on appelle un gouvernement d'ordre. Et j'ai toujours pensé que si nous arrivons à supprimer la peine de mort, ce sera pour racheter, pour rédimer, non pas le condammé à mort mais le bourreau, celui qui tue parce qu'on le force à tuer ou parce qu'on l'acheté. Mille fois meilleure est la loi de Lynch. Et je trouve plus humain l'assassin que le bourreau qui l'assassine. En tout cas: ce que au juge qui a prononcé la sentence à opérer l'exécution. L'esclavage du bourreau est le plus dégradant des esclavages.

Et, si un jour vient où il nous sera impossible de trouver un misérable qui veuille bien servir d'exécuteur? A Cuba, on vient de résoudre le problème. Là-bas, despuis que gouverne le général Gerardo Machado, formé à l'école de la barbarie policière Nord-Americaine, on a cessé de gracier les condamnés à mort et on applique la garrotte. La garrotte, dont le Roi d'Espagne, Don Alfonso de Bourbon et Habsbourg Lorraine, dit une fois —et c'est à moi qu'il adressa ses paroles- «qu'au moins c'était plus humanitaire que la guillotine car il n'y avait pas d'effusion de sang».

Que font-ils donc à Cuba? Ils choisissent l'exécuteur des hautes oeuvres parmi les criminels, lui octroient une prime de 17 dollars et demi par exécution et lui rabattent chaque fois quelques années de prison. Ainsi Paulo Romerio reconquit sa liberté après avoir supplicié huit de ses «compagnons» et reçut en plus un pourboire de 140 dollars. Pardon...«ses compagnons»? Ah! non, pas des compagnons! La dignité morale des suppliciés est supérieure à celle du bourreau qui supplicie pour gagner sa liberté et sortir de prison régénéré. Le successeur de Paulo Romerio est un certain Enrique Pineda, condamné à 37 ans de prison, dont six sont déjà écoulés. «Je veux ma liberté et c'est pour cela que j'ai accepté la charge de bourreau». Et ce très digne fonctionnaire de la République Démiocratique et Policière de Cuba a ajouté avec une profonde et macabre ironie que dès qu'il aurait recouvré la liberté il se consacrerait à la politique. Et qui sait si nous ne le verrons pas Président de la République?

Et si un jour, même les assassins qui purgent leur peine refusent l'office de bourreau en échange de la liberté? Car nous pouvons espérer cela de la conscience morale d'un de ceux que nous appelons criminels. Il nous est permis d'espérer qu'un criminel qui tua par vengeance, par jalousie ou par cupidité se refuse à assassiner pour satisfaire à ce que nous nommons la Justice. Tous les assassins, tous les criminels n'ont pas une âme d'esclave ou ce qui revient au même, une âme de tyran; car tyran ou esclave, c'est tout un.

Parfois le régime fasciste ou démiocratique se sentant faible, renonce à faire couler le sang, comme il arrive en Espagne ou l'on évite autant que possible les violences publiques (il y a, par contre, des prisionniers dont personne n'entend plus jamais parler), mais c'est surtout parce qu'en Espagne, le fascisme a pour 
but non pas tant l'assassinat que le vol d'Etat. L'occupation principale de ceux qui actuellement dirigent l'Espagne est de la piller de toutes les façons. Et il en est d'ingénieuses comme celle-ci: Primo de Rivera accepte une souscription (qu'en réalité il a lui même ouverte...) pour laquelle des conseillers municipaux et provinciaux, désignés par lui et non par un libre suffrage, s'empressent de voter de fortes sommes d'argent que l'on soutire ainsi au peuple á l'encontre de sa volonté. L'on ne saurait contester au voleur Primo de Rivera le record de l'élégance dans l'art de voler. D'ailleurs il sait s'y prendre encore de bien d'autres façon. Quant au principal bourreau du règne, le général Martínez Anido, il ne se laisse pas distancer, lui qui disait qu'il fallait rechercher ceux qui comme nous dénoncent leurs crimes, pour nous faire supplicier: «Le nerf du dentiste». Le grand artiste!

Il m'est dur de persévérer dans cette voie et je préfère laisser la plume. Je la reprendrai une autre fois pour une tâche moins pénible.

MIGUEL DE UNAMUNO

3. León Bazalgette, escritor y periodista — con el que Unamuno se carteaba desde 1903-, acababa de morir a los 55 años, víctima de una vieja enfermedad, como rezaba una breve nota necrológica aparecida en la revista el 5 de enero de $1929^{13}$. Añadía ésta que Bazalgette había alzado la voz, junto con $\mathrm{H}$. Barbusse, contra la guerra..., y que posteriormente se había unido al proletariado. Colaboró en Clarté, codirigió la revista Europe -en la que el propio Unamuno escribió ocasionalmente-, y en el momento de su muerte colaboraba en L'Humanité. él.

Unamuno, en esta tercera colaboración, recuerda su amistad con

\section{Hommage à Bazalgette ${ }^{14}$}

por MIGUEL DE UNAMUNO

Je connaissais Léon Bazalgette par correspondance il y a déjà plusieurs années, comme il venait de publier sa traduction de Walt Whitman qu'il m'envoya suivant le conseil de notre ami commun Jaime Brossa, esprit généreux, mort prématurément, en grande partie à cause de l'ombre humide de la prison de Montjuich où le tenait enfermé le régime démiocratique (démios veut dire bourreau) de l'infâme police prétorienne. Le fait est que sous pretexte de je ne sais quel attentat commis à Barcelona on se mit a la recherche de ce malheureux Brossa

\footnotetext{
13 León Bazalgette est mort..., Monde, n. ${ }^{\circ}$ 31, 5 janvier 1929, p. 3.

14 Monde, n. ${ }^{\circ}$ 34, 26 janvier 1929, p. 4.
} 
pour le jeter de nouveau en prison six mois après sa mort. Voilà un exemple de l'«organisation» policière établie par celui que j'ai surnommé le «cochon épileptique», par le général Martínez Anido, actuellement ministre de l'Intérieur et qui pour l'instant se consacre davantage au vol qu'à l'assassinat.

Arrivant à Paris, après m'être échappé de l'île de Fuerteventura où l'on m'avait déporté, un des premiers qui vint à moi pour me tendre la main, et évoquer avec moi le souvenir de Brossa, ce fut lui, ce fut Bazalgette: dans sa main il y avait tout son coeur. La vie — triste vie! — que je fus obligé de mener à Paris ne me permit pas de le fréquenter, mais les rares fois — hélas- où nous nous sommes vus, nous pûmes nous dire, les yeux dans les yeux, certaines choses indicibles.

Ce fut au cours des séances du Pen-Club que nous avons parlé le plus. Je dois dire toutefois que pendant un banquet, pour moi inoubliable, où il prit la parole, j'avais pour voisin de table Maritain, de foi thomiste, qui, par la suite, lorsque je publiai L'Agonie du christianisme m'écrivit une longue lettre scholastique, sans doute pour me convertir ou pour m'entraîner dans une polémique. Mais je n'aime pas jouer à foolgod avec des équipes de théologiens laïques qui spéculent sur la conversion.

Durant ces réunions du Pen-Club on organisa une excursion à Ermenonville pour visiter là-bas la véritable berceau du romantisme, la tombe de J.J. Rousseau. León Bazalgette fut mon compagnon le plus assidu el ce fut à cette occasion que je parlai le plus longuement avec lui. Un autre converti, Daniel Halevy, qui semblait vouloir me soumettre à une espèce d'enquête, tournait autour de moi et semblait surpris de me voir faire des cocottes en papier, ce qui est la véritable sculpture cubiste, dans laquelle — je dois le dire avec la modestie qui me caractérise - je suis passé maître. Duhamel en sait quelque chose. Et à ceux qui m'ont parfois demandé si je prenais cela au sérieux je réponds que je ne prend pas, moi, au sérieux ceux qui méprisent des jeux si profonds à mon avis, qu'ils sont les rédempteurs d'un vieil enfant. Halevy me parut pourtant satisfait quand je lui eus dit que les anciens hommes politiques espagnols étaient infiniment plus intelligents que les prétoriens qui se sont emparés du pouvoir en Espagne et qu'ils étaient généralement honorables, alors que ces prétoriens ne le sont pas. La pornocratie espagnole actuelle est la décomposition de la plus criminelle bêtise! C'est alors que je me tournai vers Bazalgette.

Je ne le verrai plus. Je commence à avoir des morts, mes morts, à Paris. Je l'ai quitté un jour, el j'ai quitté dans ce Paris, beaucoup d'amis —nul meilleur que Bazalgette- et pas un seul ennemi, que je sache. Je l'ai quitté parce qu'une frontière m'appelait où je monte la garde, une frontière, mon pays basque natal et ma mer: elle dit tant des choses à mes montagnes qui me les répètent.

Je viens de lire les lignes émues que notre Georges Duhamel — notre, de Léon Bazalgette et de mois— dédie à l'ami qui fut et qui est. Il lui dit: «tu n'as cessé pendant vingts ans d'être aimé et honoré dans ma maison» et pour moi, qui sais ce que veut dire être aimé et honoré dans la maison de Duhamel —que de fois n'ai-je pas respiré son atmosphère familiale; il y avait même là une servante avec laquelle je pouvais parler basque!- j'éprouve par ces paroles toute la tristesse de ne point avoir mieux connu Bazalgette. Et notre Duhamel ajoute: «Est-il vrai 
qu'il va nous falloir chérir une ombre?». Pindare a dit que la vie de l'homme est le réve d'une ombre lorsqu'il vit et qu'il rêve, il est vivant, qu il s'endorme d'un sommeil sans rêves, il n'est même plus une ombre. Mais puisque nous rêvons de lui, c'est tout de même un peu de lumière, n'est-ce pas, Duhamel?

Et maintenant, réconforté par le souvenir de celui qui fut un homme, et me rappelant la voix de Walt Whitman, à qui il fit parler un français universel, j'évoque une lumineuse et généreuse agonie, lutte de sa vie vraiment éternelle.

4. El 30 de noviembre de 1928, H. Barbusse escribía a Unamuno pidiéndole sugerencias acerca de la idea de un gran Congreso Internacional Antifascista a celebrar en Berlín. Este acabaría por tener lugar en marzo de 1929. Unamuno se disculpó por no poder asistir y escribió una carta a los asistentes al Congreso. El 23 de marzo apareció en Monde.

\section{Contre le fascisme $e^{15}$}

Voici le texte de la lettre que Miguel de Unamuno a envoyée au Congrès antifasciste de Berlín:

Des raisons d'ordre très privé et d'autres d'un caractère général m'empéchent de m'éloigner, pour le moment, de cette guérite frontière où $\mathrm{j}$ 'ai monté ma garde contre la tyrannie prétorienne, pornocratique et démiocratique qui s'accuge et déshonore l'Espagne; de ce coin de frontière d'où les tyrannéaux n'ont pas réussi à ce que l'on m'éloigne.

$\mathrm{J}$ 'avoue que je ne sais pas très bien ce qu'est le fascisme. En tant que doctrine, chaque jour il présente une nouvelle phase; cela en Italie, car dans ma pauvre Espagne, il ne prétend même pas étre une doctrine. On dit que dans la soidisant «Unión Patriótica», il entre de tout, même des républicains, des socialistes et des anarchistes - on exclu seulement les communistes et les séparatistes- et que ce n'est pas un parti politique. Ce n'est qu'un répugnant conglomérat de mendiants et de laquais de bourreaux dont le seul programme est de laisser s'en aller les tyranneaux prétoriens et, avec eux, le Roi, sans leur demander de comptes. «Passons l'éponge». C'est un leurre, parce que les tyranneaux savent qu'ils doivent s'en aller.

Ils s'emparèrent du Pouvoir, disant que ce n'était que pour quelques mois, mais ils durent continuer en voyant que ni les anciens politiciens ne se rendaient, ni le peuple ne les appuyait. Et aujourd'hui, ils s'adonnent au vol. Primo de Rivera, Martínez Anido et sa bande sont avant tout et sourtout des voleurs. Et l'on peut même affirmer que le Roi lui-même y obtient sa part.

15 Monde, n. ${ }^{\circ}$ 42, 23 mars 1929, p. 2. 
Il faut avant tout détruire la légende que le Roi est prisonnier des prétoriens, maître du Pouvoir Exécutif et, plus qu'éxécutif: exécuteur. Le coup d'Etat fut préparé et dirigé par le Roi lui-même qui révait, despuis longtemps, d'un pouvoir personnel, impérial et absolu, pour lequel il lui manque toutes les conditions. Mais avec sa lâcheté innée, il n’osa pas faire ce qu'a fait Alexandre de Serbie. Et il essayait même de se tromper.

Il fomenta le Coup d'Etat pour éviter les responsabilités de la campagne du Maroc — qu'il appela croisade, devant le Pape— responsabilité dont il se savait impliqué. Il me dit à moi-même: «Oui, oui toutes les responsabilités, même les miennes, si elles m'atteignent». Il essayait de me tromper. Mais je le connaissais et je savais qu'il ment toujours, même quand il dit la vérité, car alors c'est qu'il n'y croit pas lui-même. Aujourd'hui, il se voit pris dans ses propres filets. Voici que sont passées plus de cinq années sans élections d'aucune sorte (conseillers, députés provinciaux, assembléistes, tous sont toujours désignés par la tyrannie). Et malgré qu'il affirme que la suspension de la constitution est intérimaire, il ne veut pas du Parlement.

La caractéristique de la tyrannie prétorienne sur l'Espagne est, aujourd'hui sa rapacité, sa larronnerie. Et ce qu'ils dépensent pour la soutenir, une fortune, rien que pour suborner la presse étrangère et surtout la presse française.

Ils proclament leur non-violence. Ils ont peur du sang. L'affaire de Véra les effraya. Celle-là fut plus grave que celle de Matteotti, car on le fit assassiner irrégulièrement, tandis qu'on obligea le Tribunal suprême de la guerre et de la marine à condamner a mort ceux de Véra qui avaient été acquittés par un tribunal militaire faute de preuve. Encore ne le furent-ils qu'au garrot, comme me le dit le Roi Alphonse (il me le dit à moi, je l'entendis). Le garrot est plus humanitaire que la guillotine, «car il n'y a pas d'effusion de sang». Ce sont ses paroles textuelles.

Effusion de sang au Maroc (que ce même roi appela, d'après l'Episcopat, Croisade, devant le Pape). Dans les rues de Tétouan, on vendait des cartes représentant des légionnaires exhibant des têtes de Maures que couvrait un drapeau de la Croix-Rouge. Dans un des journaux les plus populaires de Madrid, on publia una photographie du banquet offert, au Maroc, à la Duchesse de la Victoire, lui présentant à table, sur un plateau, une tête de Maure bien assaisonnée.

Aujourd'hui, ils évitent déjà les cruautés publiques et s'adonnent au vol. Voleurs, voleurs, voleurs!

M. Anido lui-même «ce cochon épilectique»; celui de la loi de fuite, le plus grand bourreau du royaume, ramasse par le vol una fortune qui lui permette de fuir. Et je ne veux rien dire du sadisme crapuleux des tyranneaux qui, plus qu'autre chose, ressemblent à des ruffians de maison publique.

Une autre des caractéristiques c'est que, si les tyranneaux étaient comme quelques-uns de la Renaissance Italienne ou de l'ancienne Grèce des hommes ingénieux ou d'un sens artistique... mais Primo de Rivera et M. Anido sont des sujets à l'intelligence au-dessous de la moyenne, au-dessous de la normale. Anido est un sadique et Primo un grossier animal possédant moins de cervelle qu'un grillon, et ils ont mis à la tête de l'lnstruction Publique un ministre crétin, 
atteignant ce que les aliénistes appellent «un profond idiot». En tout cela, il n'y a ni grandeur tragique, infernale. Mais il suffit car mon coeur se serre quand je dois, triste devoir, parler de ces choses.

Pour mon Espagne, pour ma pauvre Espagne, ma mère et aussi ma fille, je vous demande, congréssistes, de répandre la vérité. La Justice est la liberté de la vérité.

Hendaya, le 4 mars 1929

Miguel de Unamuno

Pues bien, la historia en torno a lo sucedido con el manuscrito original de esta carta, es cuanto menos curiosa.

Mientras investigaba la recepción de la noticia de la muerte de Unamuno, en la prensa de ambos bandos durante la guerra civil - de cara a la elaboración de mi tesis doctoral sobre la evolución del pensamiento político de Unamuno- me encontré con una pequeña sorpresa. Concretamente en el periódico La Batalla, órgano del P.O.U.M. El día 3 de enero de 1937 publicaban la noticia, telegrafiada desde Avila, del entierro de Unamuno. Acto desarrollado con gran sencillez... y al que no asistió «ningún representante de los facciosos, lo cual parece confirmar las noticias que habían circulado sobre un desacuerdo a última hora entre Miguel de Unamuno y los fascistas» ${ }^{16}$. (Téngase en cuenta la falta casi total de información sobre el suceso del 12 de octubre en la zona «roja», ya que fue ocultado por la propia prensa de Salamanca, y sólo circuló como rumor, tardando varios meses más en ser confirmado con un cierto conocimiento de causa). Y al día siguiente publicaban esta carta - Un documento de Miguel de Unamuno contra el militarismo y el fascismo-, precisamente como contraste entre el Unamuno de 1929 y el de 1936: «QQuién iba a decir que el hombre que así atacaba al militarismo y al fascismo español en 1929, iba a morir, en 1937, al lado de los militares fascistas!»17.

Y nos cuentan las circunstancias por las que la carta de Unamuno había llegado a sus manos. Este, al no poder ir a Berlín, encargó al miembro del P.O.U.M., Gorkin, que iba a la cabeza de una delegación española, la traducción y lectura de la misma.

Y lo que es más importante, la fotografía de la segunda mitad de la carta con la firma de Unamuno aportada por el periódico, confirma su autenticidad. Por ello, la reproducimos a continuación al tratarse del manuscrito original desconocido hasta hoy.

16 La Batalla, Organo Central del P.O.U.M., Barcelona, 3 enero 1937, p. 4.
${ }_{17}$ La Batalla, Organo Central del P.O.U.M., Barcelona, 4 enero 1937, p. 1. 


\section{contra el militaris-}

\section{$y$ el foscismo}

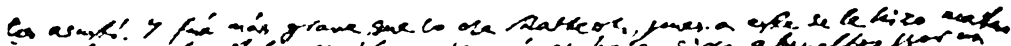

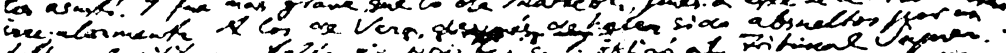

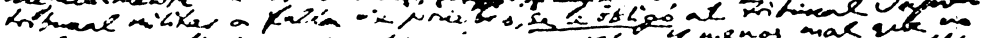

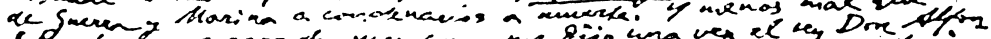

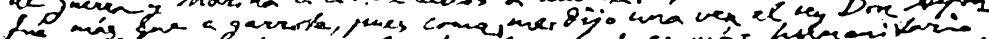

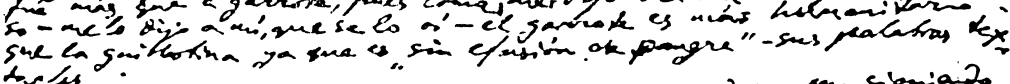

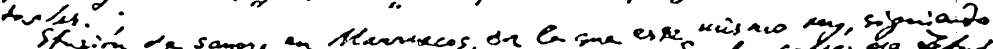

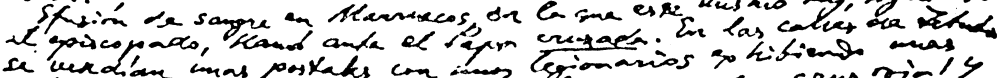

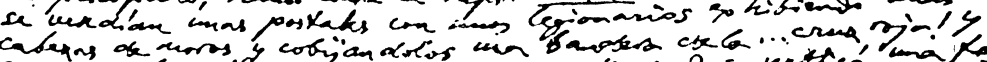

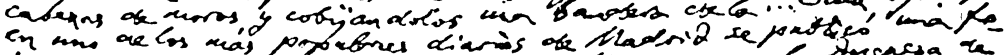

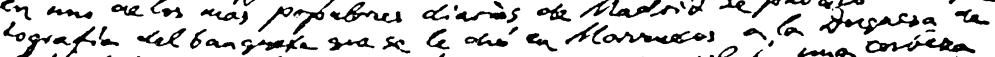

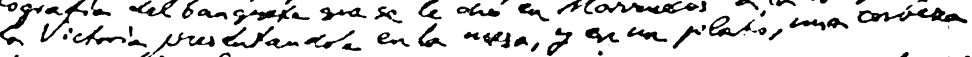

dy mozo tivin aberesak.

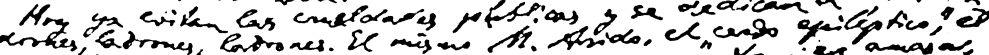

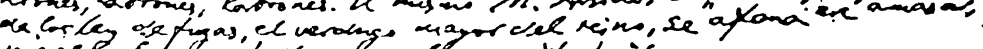

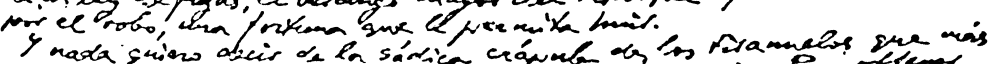

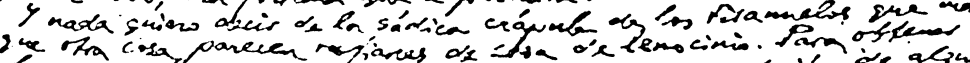

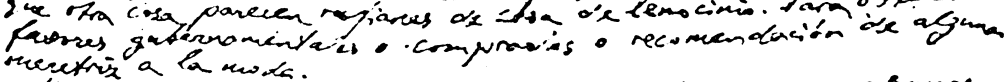

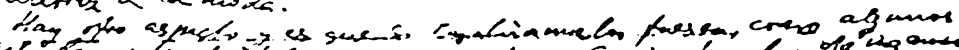

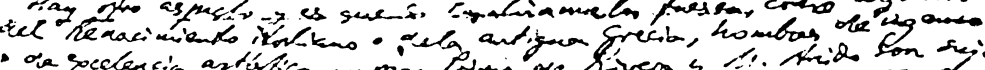

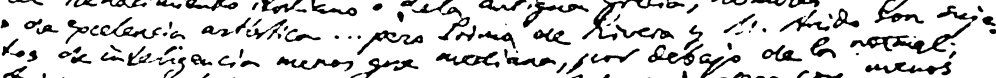

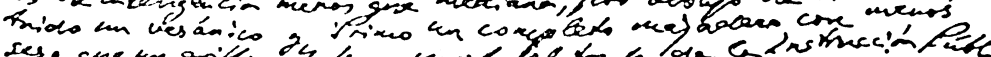

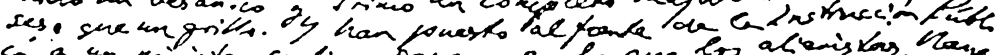

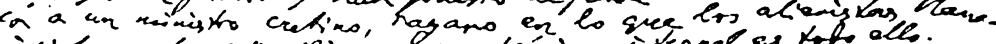

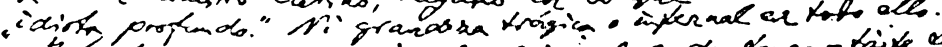

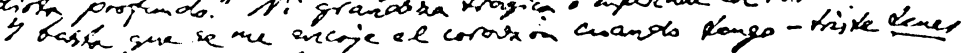
que pore hontie de estors coses

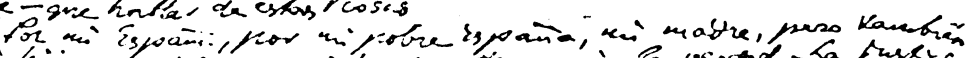

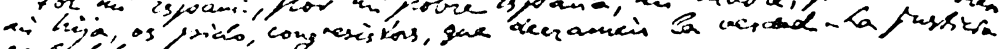

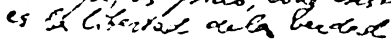
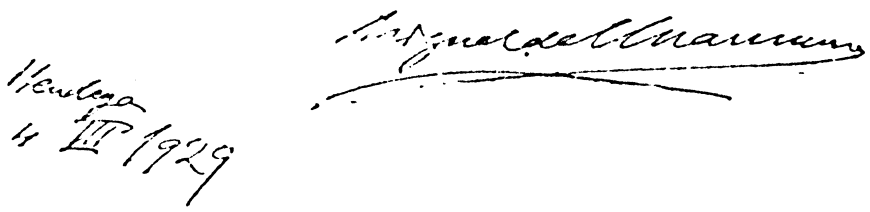


\section{Al Congreso Antifascista de Berlín: ${ }^{18}$}

Razones de orden muy privado pero otras de carácter general me impiden alejarme por ahora de esta garita fronteriza en que tengo montada mi guardia contra la tiranía pretoriana, pornocrática y cleptocrática que saquea y deshonra a España; de este rincón de frontera de donde los tiranuelos no han logrado que se me aleje.

Confieso que no sé muy bien lo que es el fascismo. Como doctrina, cada día presenta una nueva cara. Esto en Italia, que en mi pobre España ni aún pretende ser doctrina. Dicen que en la llamada allí Unión Patriótica caben todos, incluso republicanos, socialistas y anarquistas — sólo excluyen a comunistas y separatistas- y que no es partido político. No es más que un repugnante conglomerado de mendigos y asistentes de verdugos cuyo único programa es dejar ir a los tiranuelos pretorianos, entre ellos el rey, sin pedirles cuentas. «Borrón y cuenta nueva», es su lema. Porque los tiranuelos saben que tienen que irse.

Se adueñaron del poder diciendo que para unos meses y han tenido que seguir en él al ver que ni los antiguos políticos se les rendían ni el pueblo les apoyaba. Y hoy se dedican a robar. Primo de Rivera, Martínez Anido y su banda son ante todo y sobre todo, ladrones. Y puede asegurarse que el rey va a la parte.

Ante todo hay que desvanecer una leyenda y es de que el rey esté prisionero de los pretorianos, dueños del poder ejecutivo, y más que ejecutivo, ejecutor. El golpe de estado lo preparó y dirigió el rey mismo, que soñaba hacía tiempo con el poder personal, imperial y absoluto para el que, por lo demás, carece de condiciones. Pero con su cobardía ingénita, no se atrevió a hacer lo que el rey Alejandro de Servia. Y hasta trata de engañar.

Inició el golpe para evitar las responsabilidades por la campaña de Marruecos — cruzada la llamó ante el Papa- que sabía le alcanzaban. A mí mismo me dijo: «Sí, sí, todas las responsabilidades, hasta las mías si me alcanzaren». Trataba de engañarme. Pero le conocía y sabía que miente siempre, hasta cuando dice la verdad, pues entonces es que no lo cree. Y hoy se ve cogido en sus propias redes. Van más de cinco años sin elecciones de ninguna clase - concejales, diputados provinciales, asambleístas - , todos son nombrados por la tiranía, no quiere Cortes.

Lo característico hoy de la tiranía pretoriana sobre España es la rapacidad, su ladronería. Y lo que gastan para sostenerla. Sólo en sobornar a la prensa extranjera, sobre todo francesa, una millonada.

Proclaman su no violencia. Le tienen miedo a la sangre. Lo de Vera les asustó y fue más grave que lo de Matteoti, pues a éste se le hizo matar irregularmente. A los de Vera, después de haber sido absueltos por un tribunal militar a falta de pruebas, se le obligó al Tribunal Supremo de Guerra y Marina a condenarlos a muerte. Y menos mal que no fue más que a garrote, pues como me dijo una vez el rey Don Alfonso — me lo dijo a mí, que se lo oí- «el garrote es más humanitario que la guillotina, ya que es sin efusión de sangre», sus palabras textuales.

Efusión de sangre en Marruecos, en la que este mismo rey, siguiendo al episcopado, llamó ante el Papa cruzada. En las calles de Tetuán, se vendían unas postales con unos legionarios exhibiendo unas cabezas de moros, y cobijándolos una bandera de la... cruz roja! Y en uno de los más populares diarios de Madrid se publicó una fotografía del banquete que se le dió en Marruecos a la Duquesa de la Victoria, presentándole en la mesa, y en un plato, una cabeza de moro bien aderezada.

18 Ibidem. 
Hoy ya evitan las crueldades públicas y se dedican a robar. Ladrones, ladrones, ladrones. El mismo M. Anido, el «cerdo epiléptico», el de la ley de fugas, el verdugo mayor del reino, se afana en amasar por el robo, una fortuna que le permita huir.

Y nada quiero decir de la sádica crápula de los tiranuelos que más que otra cosa, parecen rufianes de casa de lenocinio. Para obtener favores gubernamentales o comprarlos o recomendación de alguna meretriz a la moda.

Hay otro aspecto y es que si los tiranuelos fuesen, como algunos del «Renacimiento italiano» o de la antigua Grecia, hombres de ingenio o de excelencia artística... pero Primo de Rivera y M. Anido son sujetos de inteligencia menos que mediana, por debajo de la normal; Anido un vesánico y Primo un completo majadero con menos seso que un grillo. Y han puesto al frente de la Instrucción Pública a un ministro cretino, rayano en lo que los alienistas llaman «idiota profundo». $\mathrm{Ni}$ grandeza trágica o infernal en todo ello.

Y basta, que se me encoje el corazón cuando tengo - triste tener que- que hablar de estas cosas.

Por mi España, por mi pobre España, mi madre, pero también mi hija, os pido, congresistas, que derraméis la verdad. La justicia es la libertad de la verdad.

Miguel de Unamuno

Hendaya, 4 III 1929

5. Appel aux pères espagnols se inscribe en el marco general de la lucha contra la dictadura. Y concretamente en la de los estudiantes, que constituyeron un núcleo importante que contribuyó a la caída de la misma.

Durante el curso 1926-27 se había constituido la Federación Universitaria Escolar, FUE, sin reconocimiento legal, que sería fundamental en la lucha contra la política educativa de Primo de Rivera. Esta alcanzaría su máxima expresión en la oposición al decreto del 29 de mayo de 1928 - especialmente a un artículo del mismo, el art. 53, que favorecía a las Universidades privadas frente a las públicas-, y que acabaría por culminar, tras huelgas y revueltas estudiantiles, dimisión de catedráticos y la clausura de las Universidades de Madrid y Barcelona en marzo de 1929, con la derogación del citado artículo el 21 de setiembre de 1929.

En este contexto, el domingo de Pasión de 1929, Unamuno escribió una carta abierta A los estudiantes de España -exhortándoles a la lucha contra la dictadura-, que circuló profusamente por España en hojas mecanografiadas y que sería publicada en Hojas Libres.

Salvad a España, estudiantes, salvadla de la injusticia, de la ladronería, de la mentira, de la servilidad y, sobre todo, de la sande ${ }^{19}$.

19 Miguel de Unamuno, «A los estudiantes de España», Hojas Libres, 28 marzo 1929, p. 1. Recogida por José LóPEZ-REY, Los estudiantes frente a la Dictadura, Madrid, Javier 
Y el 22 de abril, escribiría la carta abierta $A$ los padres españoles que reproducimos a continuación - y de la que el texto de Monde no es sino un fragmento-, pidiendo a los padres que apoyaran a sus hijos.

\section{A los padres españoles: ${ }^{20}$}

Es menester, padres españoles conscientes, que os deis cuenta de todo el sentido y alcance de la patriótica protesta de la juventud intelectual española. Lo del privilegio de examen a los industriales pedagógicos jesuitas y agustinos, no ha sido más que un achaque para el estallido. Venía éste fraguándose desde que el desatinado tiranuelo, que antepone sus piques de histérico amor propio al prestigio de la función que se ha arrogado, trató al estudiante Sr. Sbert como a un recluta, hiriéndose de que éste le hubiese dado una lección. Y luego se exasperó al ver que no se le rendía pidiéndole gracia. Y esto, el que haya querido tratar a los jóvenes españoles como a reclutas a los que no les es dado discutir las que llaman «directivas del mando», sino obedecerlas con el tercer grado de la obediencia jesuítica, esto es lo que ha sublevado a la noble juventud ciudadana. Y la ha sublevado contra la dictadura misma, que siendo como es injustificada, pues la rechaza la casi totalidad del pueblo español consciente, no es ya dictadura, sino tiranía, y tiranía de la necedad cobarde.

El tercer grado de la obediencia jesuítica. Aquí está la inspiración loyolana de Primo y consortes. Ese tercer grado, según el mismo Loyola lo establece en celebérrima carta, es la obediencia de juicio en que se ha de creer que lo que manda el superior es lo mejor. Mas esto no cabe imponérselo a jóvenes dedicados al estudio, a la libre investigación, a la crítica, y que si son cristianos han de saber que el Apóstol Pedro dijo que antes hay que obedecer a Dios que no a los hombres. Y a esos jóvenes, cuando les habla en su conciencia racional Dios, no es por la boca de ganso histérico de Primo.

No, la juventud estudiantil y estudiosa española no está formada por leva de reclutas mecanizados ni siquiera de esos ridículos bueyes cautos o como se diga —en inglés boyscouts - ni ha aprendido patriotismo en aquel dechado de tontería $\mathrm{y}$ vaciedad que fue cierto catecismo del ciudadano que al principio de la vergüenza se impuso en las escuelas primarias. Algo que al leerlo da ganas de olvidar que se es español. No, la juventud estudiantil y estudiosa española no puede tolerar que se anteponga a la religión - vergonzosamente a Dios- la Patria, para anteponerla a la Justicia, ni puede por patriótica religión, por religioso patriotismo,

Morata, 1930, pp. 143-146. López-Rey fue uno de los primeros dirigentes dc la FUE, y él junto a María Zambrano y otro compañero, escribieron una contestación que hicieron llegar a Unamuno (Ibid., pp. 146-148). La carta de Unamuno ha sido recientemente publicada por Laureano Robles: Miguel de Unamuno, Epistolario inédito II (1915-1936). (Edición de Laureano Robles), Madrid, Espasa-Calpe, 1991, pp. 260-262.

${ }^{20}$ Véase José LÓPEZ-REY, ob. cit., pp. 149-152. Reproducida posteriormente por Eduardo Comín Colomer, Unamuno libelista. Sus campañas contra Alfonso XIII y la Dictadura, Madrid, A. Vasallo editor, 1968, pp. 83-85. Dado que ambos libros son poco accesibles y además lo publicado en Monde no es sino un fragmento, publicamos la carta en su integridad sirviéndonos del ejemplar que se conserva en la CMU (9-126). 
soportar que se pretenda hacer a palos o a multas, que se grite ¡viva España! No ya los estudiantes nacionalistas catalanes, vascos o gallegos, sino todos, todos ellos, los que más españoles se sientan, tienen que rechazar ese paganismo patriotero, castrense y la superstición fetichista de la bandera. Quédese para los que de ella viven y medran, los que la explotan, y no siempre con honor, y sinceridad de fe, quédese para los perjuros.

La juventud española, que ya antes vertió en Marruecos su sangre por una causa que no era suya, ni de su verdadera patria, no puede plegarse a la ordenación pretoriana. Y en otro respecto, esa juventud, de la que saldrán los obreros de las llamadas profesiones académicas, hermanos de los trabajadores industriales, no pueden plegarse a un régimen en que se persigue la sindicación obrera independiente; esa juventud, en el más hondo sentido socialista, así como ha señalado a sus maestros académicos su deber, tiene que señalárselo a los monitores del sumiso obrerismo oficioso que ven impasibles que se persiga a los obreros que no son de su parroquia ni su secta.

Es sagrado deber de esa juventud, padres españoles, el crear política contra la infame policía, cuando sus padres no saben o no quieren hacerla; es sagrado deber de esa juventud despertar en sus desgraciados padres y abuelos, en los de mi generación, el sentimiento de la dignidad que parece que se les ha dormido si es que no muerto. Y lo que sobre todo no puede, porque no debe tolerar esa juventud - bendita sea - es el que un mentecato histérico, sirviendo de muñeco a los que le tiran de los hilos, esté haciendo que España sea el ludibrio del mundo civilizado. No debe soportar el que a sus padres se les trate peor que a los borregos, y esto aunque lo merezcan. Tiene el deber de arrastrar fuera del ruedo a ese indigno payaso; indigno porque carece hasta de la dignidad de payaso.

Esa juventud, padres españoles, es nuestro porvenir, es nuestra esperanza y si no queréis que mañana quiera olvidarnos por modo de triste perdón, a nosotros, a sus padres; si no queréis que se avergüence del nombre que les hemos de legar, tenéis que ayudarles y con más que un recatado aplauso. Dejarles solos es preparar el más triste de nuestros tránsitos, el de que volvamos a la tierra madre con un amargo responso «que Dios les perdone», en la boca de nuestros hijos.

Si abandonáis, españoles, vuestros hijos a los polizontes, a los verdugos, a los cabos de vara y a los que les dicen que pueden fusilar, reclutas, a sus jefes, los abandonáis a los que mañana les enseñarán a despreciaros a vosotros, a sus padres. Todo lo que se diga en execración del llamado antiguo régimen, no será nada al lado de esto. Si los abandonáis, podrán renegar de nuestra paternidad y decirse hijos sólo de sus obras.

Yo por mi parte, no renuncio, ni a la majestad ni a la responsabilidad de padre. Y me siento espiritualmente padre de todos los jóvenes estudiantes y de los obreros. Les he dado la sangre de mi alma, y frente a «la masculinidad caracterizada» del animal tiranuelo castrense, levanto mi paternidad espiritualizada, no quiero que nuestros hijos, nuestros nietos, me despidan, cuando deje esa España de mis padres y de mis hijos, con desdeñoso «que Dios le perdone».

Padres españoles: sed padres dignos de vuestros hijos y creed con obras en la resurrección de la España civil bajo la Justicia.

MIGUEL DE UNAMUNO

Hendaya, 22-1V-1929 


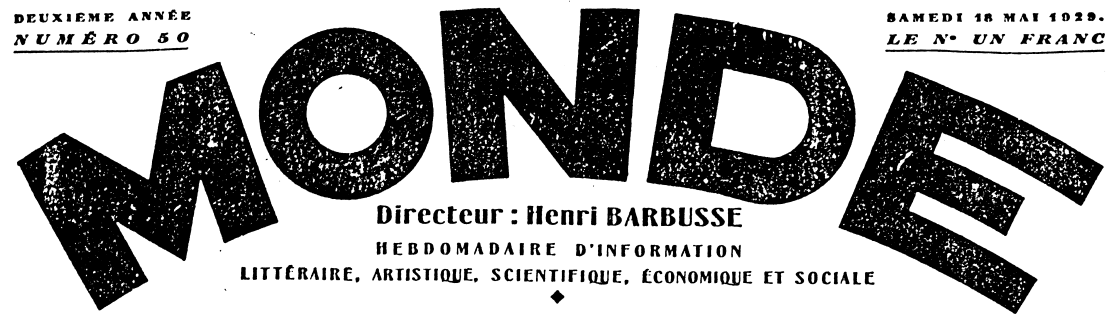

COMITE DIRECTEUR : A. EINSTEIN, M. GORKI, UPTON SINCLAIR, M. UGARTE, M. DE UNAMUNO, M. MORHARDT, LEON WERTH

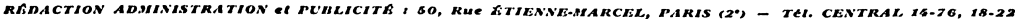

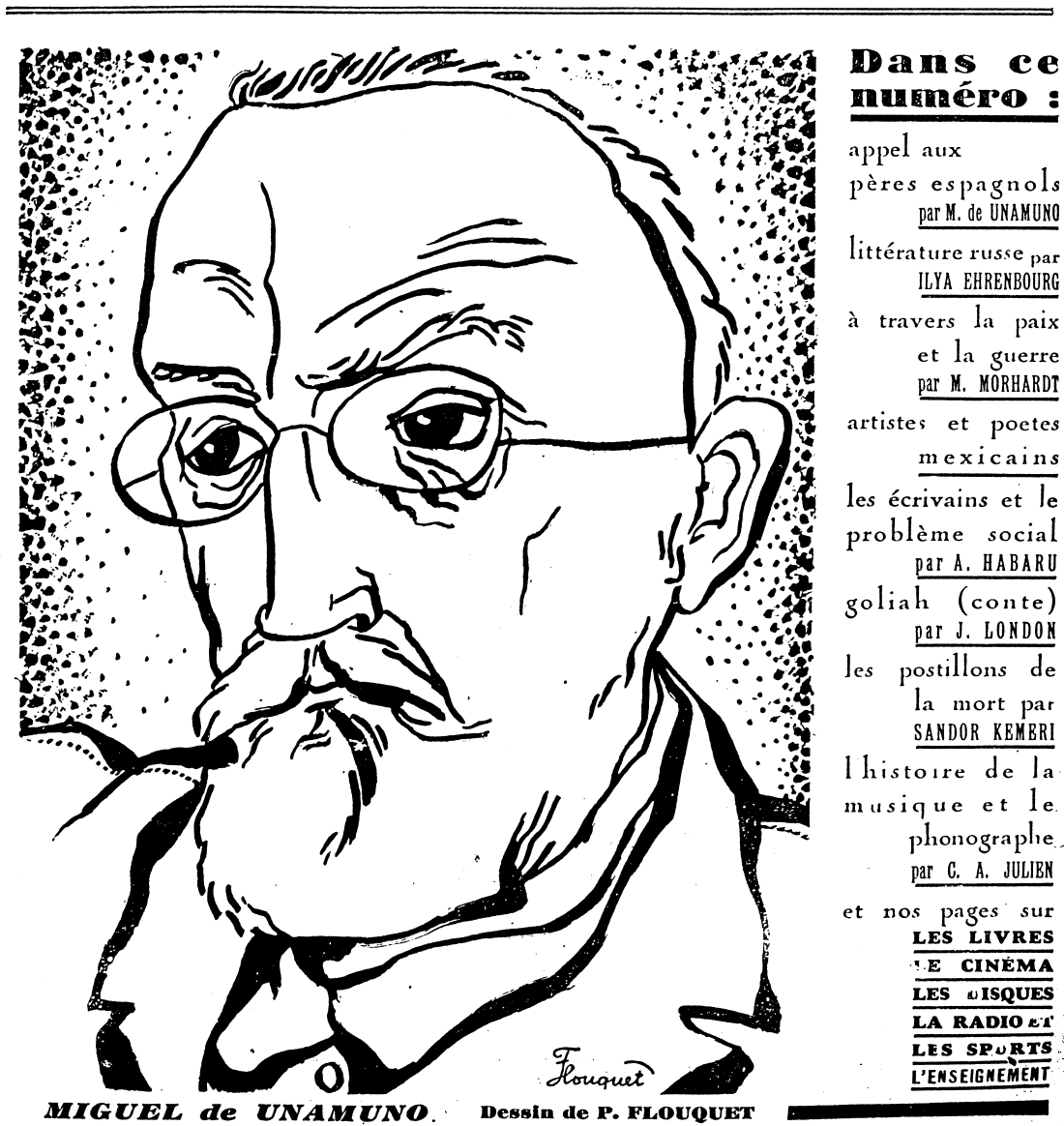


El texto de Monde, precedido de un breve encabezamiento, dice así:

\section{Appel aux pères espagnols ${ }^{21}$ par Miguel de Unamuno}

A l'occasion de graves événements qui ont dressé les étudiants et professeurs espagnols contre la dictadure de Primo de Rivera, Miguel de Unamuno vient d'adresser aux pères espagnols un vibrant appel dont nous détachons le passage suivant:

La jeunesse espagnole, qui a déjà versé au Maroc son sang pour une cause qui n'était pas la sienne, ni celle de sa véritable Patrie, ne peut pas se plier à l'ordre prêtorien. Et, d'un autre côté, cette jeunesse, de laquelle sortiront les ouvriers de ce qu'on appelle les professions libérales, les frères des travailleurs manuels, ne peut pas se plier à un régime dans lequel on poursuit l'association syndicale ouvrière indépendante. Cette jeunesse, dans le sens le plus profond, est socialiste et, de même qu'elle a montré à ses maîtres académiques leur devoir, elle doit le montrer aux moniteurs du syndicalisme officieux qui regardent, impassibles, poursuivre les ouvriers qui ne sont pas de leur chapelle.

C'est un devoir sacré de cette jeunesse, pères espagnols, de dresser une politique contre l'infâme police lorsque leurs pères ne savent pas ou ne veulent pas la faire, c'est un devoir sacré de cette jeunesse d'éveiller chez leurs malheureux pères et grands-pères, chez ceux de ma génération, le sentiment de la dignité, qui semble s'être endormi en eux, s'il n'est pas mort. Et, surtout, ce que ne peut pas tolerer, parce qu'elle ne le doit pas, cette jeunesse - bénie soit-ellec'est qu'un histérique insensé, servant de pantin à ceux qui tirent les ficelles, fasse de l'Espagne la risée du monde civilisé. Elle ne doit pas supporter celui qui traite ses pères pire que des condamnés, et cela bien quils le méritent.

Cette jeunesse, pères espagnols, est notre avenir, notre espérance, et si vous ne voulez pas que demain elle veuille nous oublier en guise de triste pardon, nous, ses pères, si vous ne voulez pas qu'elle ait honte du nom que nous devons lui léguer, vous devez l'aider, et autrement que par un timide applaudissement. Les laisser seuls, c'est préparer le plus triste de nos destins, que nous retournions à la terre maternelle avec une amère prière: «Que Dieu leur pardonne», dans la bouche de nos fils.

$\mathrm{Si}$ vous abandonnez, espagnols, vos fils aux policiers, aux bourreaux, aux adjudants et à ceux qui disent qu'on peut fusiller des recrues, à leurs chefs, vous les abandonnez à ceux qui, demain, leur enseigneront à mépriser leurs pères. Tout ce qu'on dira en exécration de ce qu'on a appelé l'ancien régime ne sera rien à côté de cela. Si vous les abandonnez, ils pourront renier votre paternité el se dire les sens fils de leurs oeuvres.

Pères espagnols, soyez des pères dignes de vos fils et croyez, par vos oeuvres, à la résurrection de l'Espagne civile sous la Justice.

MIGUEL DE UNAMUNO

${ }^{21}$ Miguel de UnAmuno, «Appel aux pères espagnols», Monde, n. ${ }^{\circ}$ 50, 18 mai 1929, p. 7. 
6. Por último, también conocemos el más que probable texto original de este artículo ${ }^{22}$.

Al parecer, el redactor jefe de Monde, M. Habaru, entregó el manuscrito autógrafo del mismo al corresponsal en París, C. DeambroisMartins, de la revista chilena Atenea, que lo publicó ${ }^{23}$.

El artículo había sido escrito para Monde y publicado tres meses atrás.

\section{Connaissez-vous les uns les autres ${ }^{24}$ par Miguel de UNAMUNO}

Il me plaît de constater l'effort de Monde pour faire connaître a son public, à son peuple français — du moins par la langue — l'âme, c'est-à-dire l'humanité, des autres peuples, du reste du peuple humain. Et non pas par exotismo esthétique. C'est ce qu'il a de mieux à faire pour la plus grande humanisation de son peuple.

«Connais-toi toi-même», disait l'oracle de Delphes. (Il fallait que ce fût un oracle!). Mais personne ne peut se connaître soi-même si ce n'est pas le miroir des autres, surtout de ceux qui en apparence, diffèrent le plus de nous. Il faut dire: «Connaissez-vous les uns les autres», ce qui est plus élevé que de dire «Aimez-vous les uns les autres». Puisque Charles Lamb disait déjà: «Je ne peux pas hairr celui que je ne connais pas». Et haïr, n'est-ce pas parfois, aimer?

Dans la discussion et dans la dispute les hommes apprennent à se connaître. Un vieux marin de ma côte basque me disait un jour que dans le monde il avait trouvé des hommes que vivaient tous nus, d'autres couverts de peaux et de fourrures. Ceux-là ne mangent que des légumes, ceux-ci que de la viande. Ici on ne croit pas en Dieu, là tout est divinisé, et cependant tous vivent. Il en concluait qu'il ne faut pas discuter. Mais, dès qu'on vit comme cela, sans discuter, sans se disputer, on vit en animal et non pas humainement. La vie de l'esprit est une perpétuelle discussion. Il faut disentir pour consentir. La haine même, si fraternelle, si humaine, est une forme de l'harmonie. La parole la moins humaine est la parole étrangère —extraneus - du dehors, d'extra. Mais hors de moi, extra mei rien n'est humain.

Il était beaucoup plus profond que mon vieux marin basque, l'Andalous qui disait à son maître: «Ne vous en faites pas, Monsieur, dans ce monde nous savons tout, entre tous». Tout ce que l'on fait. Ce que l'on ignore, nous l'ignorons tous

22 Rafael OsunA, «Un artículo olvidado de Unamuno», Insula, n. ${ }^{\circ} 431$, octubre 1982, p. 1.

${ }^{23}$ Según la referencia dada por Osuna en su artículo: Atenea, Santiago de Chile, XII, 57, setiembre 1929, pp. 158-161. De donde sería reproducido posteriormente por Repertorio Americano, San José de Costa Rica, XIX, 1929, p. 316.

${ }^{24}$ Miguel de Unamuno, «Connaissez-vous les uns les autres», Monde, n. ${ }^{\circ}$ 53, 8 juin 1929 , p. 3. Texto que Rafael Osuna confiesa que «no nos ha sido hacedero allegar» (art. cit.). 
ensemble et tout ce que nous savons, ce sont nos contradictions intérieures qui nous l'ont appris. L'ignorance de mes semblables m'apprend que j'ignore ce que je croyais savoir. Nos connaissances —et nos ignorances- sont complémentaires.

Là où s'impose par dictadure religieuse, politique, sociale ou esthétique un dogme quelconque, on finit par ne plus le reconnaître. L'orthodoxie c'est l'ignorance. (Exemple: les marxistes orthodoxes sont ceux qui ne connaisent par Marx). L'unité dogmatique fait la foi du charbonnier, qui n'est que l'ignorance de la foi. Quand tout le monde s'imagine croire la même chose, c'est que personne ne croit rien du tout.

Je vais chercher chez les autres ce qui me manque pour être plus «moi-même». Chaque ami nouveau m'enrichit, plus que par ce qu'il me donne, par ce qu'il me révèle de moi-même. Pour porter en moi mes 1.024 aïeux de 10 générations; je porte en moi tous mes contemporains.

Et il en est de même avec les peuples. Et de même avec ses dieux, qui ont tous existé. Henri de Montherlant, ce pessimiste si consolant, disait dans un article d'une profonde compréhension —comprendre, c'est aimer- du côté le plus humain, le plus universel de l'âme espagnole: «Lâcher bride à toutes ses tendances, fussent-elles discordantes, dire toujours oui à la vie, c'est croire que tout est verité, que tout est erreur, bref que tout se vaut. Et c'est le titre même d'une pièce de ce Calderon que les Espagnols reconnaissent, avec Cervantes, pour l'écrivain le plus représentatif de leur race: En esta vida todo es verdad y mentira. (Dans cette vie tout est verité et tout est erreur) ${ }^{25} \gg$. (Entre parenthèse, Mentira ce n'est pas l'erreur mais le mensonge. Quant à ce qu'ils appellent vérité, il faut le prendre au jour le jour, parce que demain c'est l'erreur et après-demain le mensonge).

Le plus grand scepticisme c'est l'omniaffirmation. Ce qu'il y a de plus consolant, c'est le pessimisme —un pessimisme comme celui de mon semblablemi proximus Montherlant. Mais si ce monde — qui est le seul possible - est la pire des possibilités, le résultat est excelent. Et il est excellent parce que on y vit et qu'on y jouit. Et même qu'on s'y amuse. Quelques-uns en faisant du pesimisme. Et la joie c'est ce qui a de plus sacré. Au point que les peuples se révoltent parce qu'on ne les laisse pas s'amuser à leur maniere —en chantant leurs peines, par exemple_avant qu'ils se révoltent par manque de pain.

Il y a beaucoup plus de bagarres, en Castille, pour la suppression d'une «corrida» qu'à cause de la disette de pain ou d'une revendication de salaires. Et le bonheur d'un Leopardi fut-il autre chose que la malédiction de sa naissance et le chant de cette malédiction? Et de quoi tira-t-il plus de vanité, le très vain Salomon, si ce n'est d'avoir dit «vanité des vanités»?

25 La cita de Montherlant aparece en francés, y la obra de Calderón en español. De ahí que este paréntesis traduciéndola fuera añadido por la revista, al menos según la versión del artículo que ofrece Osuna. Igualmente, la primera frase del siguiente paréntesis es introducida por la revista. A continuación ILS — qu'ils appellent verité- sustituye a: «los dogmáticos o sea los dictadores». Por último, tras el paréntesis, la siguiente frase del manuscrito en castellano - junto con otra anterior- es suprimida. (Véase R. OsunA, art. cit.). 
«Mon repos, c'est de me battre», dit un proverbe espagnol. Et ma façon de me battre, c'est de connaître, grâce à la querelle.

Connaître? Aimer? Il y a quelque temps Benedetto Croce se moquait de cette ridicule question qu'on lui pose tant de fois a l'étranger: «Aimez-vous la France? Aimez vous...?».

Comme s'il s'agissait d'une cocotte ou d'une maîtresse. Moi, quand un Français me demande cela je lui réponds: «Et vous, français, connaissez-vous la France? Si vous ne connaissez pas le reste du monde vous ne connaissez pas votre pays, et partant, vous ne l'aimez pas».

Voila pourquoi j'aime l'effort que fait Monde pour que le peuple français apprenne, dans le miroir des autres peuples, à découvrir en lui-même des qualités ignorées. Et que ce peuple français qui s'intitule celui de la mesure, apprenne à mesurer non pas à l'aide exclusive du système métrique de son invention, mais quelques fois aussi par «yards», «feet» et «inches» ou par «varas», «pies» et «pulgadas» castillanes.

Connaissons-nous les uns les autres pour nous connaître nous-mêmes. 


\title{
DAÑOS PUNITIVOS \\ EN EL PROCESO CIVIL NORTEAMERICANO*
}

\author{
Dr. Goretti Vadillo Robredo
}

Sumario: I. Definición y antecedentes. II. Elementos diferenciadores. II.1. Conducta del demandado. II.2. Acciones en las que se permite. II.3. Relación daños compensatorios y daños punitivos. III. Funciones y justificaciones. III.1. Función compensatoria. III.2. Función de castigo o punitiva. III.3. Función disuasoria. IV. Problema actual: Daños punitivos v. Responsabilidad por Productos defectuosos. IV.1. Roginsky v. Richardson-Merrell/Toole v. Richardson-Merrell. IV.2. Grimshaw v. Ford Motor Co. IV. 3. Características comunes. IV.3.a. El demandado conocía la existencia del defecto. IV.3.b. EI demandado recibía importantes beneficios económicos de la fabricación y venta del producto. IV.3.c. El demandado no realizó investigaciones de forma eficiente, o no hizo esfuerzo alguno para remediar el daño. IV.3.d. La actuación del demandado superó los modelos de conducta de la industria. IV.3.e. El producto no ofrecía beneficios sustanciales que compensasen el riesgo. V. Reformas. V.1. Abolición de los daños punitivos. V.2. Instaurar límites en el quantum de la condena. V.3. Entregar el quantum de la condena total o parcialmente a un fondo estatal. V.4. Bifurcación del proceso o abolición del jurado. V.5. Equiparación con el nivel de prueba del Derecho penal. V.6. Prueba de la riqueza del demandado. V.7. Delimitación precisa de la conducta del demandado. VI. Recapitulación. Anexo.

\section{Definición y antecedentes}

La figura de los daños punitivos es desconocida en nuestro Derecho civil, pero no así en el Derecho anglosajón, en el que ha adquirido una gran importancia económica. Partiendo de la doctrina que nació en In-

\footnotetext{
* La realización de este artículo ha sido posible a una beca del Gobierno Vasco (Programa de becas postdoctorales de perfeccionamiento de personal investigador) disfrutada entre 1996-1997.
} 
glaterra en $1763^{1}$, esta figura se ha desarrollado en los Estados Unidos llegando a convertirse en una de las causas que habitualmente se alega para explicar la crisis actual de los seguros y del Derecho de tort.

El Restatement (Second) of Torts ${ }^{2}$ los define en la sección, 908:

(1) «Los daños punitivos son daños, distintos de los daños compensatorios o de los daños nominales, que se indemnizan en contra de una persona para castigarle por su conducta ultrajante y para disuadirle a ella y a otras de conductas similares en el futuro.

(2) Los daños punitivos pueden ser indemnizados por una conducta que es ultrajante, debido a su motivación perversa o a su descuidada indiferencia hacia los derechos de los otros. En la valoración de los daños punitivos, el trier of fact puede adecuadamente considerar el carácter del acto del demandado, la naturaleza y la extensión del daño de la víctima que el demandado ha causado o ha intentado causar, y la riqueza del demandado.»

En el Derecho continental, la división entre ilícito civil y penal es, en principio ${ }^{3}$, clara. Ciertas conductas dan lugar a la obligación de indemnizar mientras que a otras se les aplica una pena. Esta división parece no estar tan clara en el Derecho anglosajón, en donde se dice que el fin primario de una condena de daños es el de compensar a la víctima, y un posible fin secundario es el castigo ${ }^{4}$. Los daños punitivos se crean para llevar a cabo la función de castigo por una conducta ultrajante o por poseer la conducta del agente de ciertas características especiales. Sin embargo, la doctrina y la jurisprudencia anglosajonas no son uniformes sobre este tema.

En Gran Bretaña la figura fue modificada en 1964 por Lord Devlin en Rookes v Barnard ${ }^{5}$. Lord Devlin consideraba a los daños ejemplares o daños punitivos como una anomalía. En su opinión, los «daños agravados» explicaban muchos de los casos que hasta ese momento habían

${ }^{1}$ La doctrina de los daños punitivos recibió su primera articulación explícita en Inglaterra, en el caso Wilkes v. Wood, (2 Wils K.B. 203, 95 Eng. Rep. 766, C.C.P. (1763)). También aparece en Huckle v. Money, (2 Wils KB 205, 95 Eng. Rep. 768 (1763)).

2 American Law Institute, Restatement of the Law, (Second) of Torts, St. Paul, Minn., 1966-1982. El Restatement of Law está compuesto por una serie de volúmenes elaborados por el American Law Institute en el que se recoge lo que la ley es en general, cómo cambia, y cuáles son las direcciones, según los autores, que debe tomar en el futuro. Los tribunales los citan frecuentemente en sus sentencias. Representan el fruto de trabajo de la doctrina más prominente en campos diversos, por ejemplo el Restatement of Contracts, Restatement of the Law of Torts, etc.

${ }^{3}$ Existen, no obstante, algunos aspectos punitivos en nuestro Derecho civil, aunque no son claramente reconocidos.

${ }^{4}$ Ver, por ejemplo McGregor, McGregor on Damages, $14 .^{a}$ ed., Sweet \& Maxwell, London, 1988.

${ }^{5}$ La reforma realizada por Lord Devlin se recoge en Rookes v. Barnard 1 All E.R. 367 (A.C. 1964). 
sido considerados como supuestos de daños ejemplares ${ }^{6}$. En Rookes se limitaron los daños ejemplares a tres categorías:

1. Las acciones inconstitucionales, arbitrarias u opresivas de los empleados del Gobierno.

2. Cuando la conducta del demandado ha sido calculada para obtener un beneficio que exceda la compensación en la que posiblemente incurriría si es declarado responsable.

3. Cuando una ley expresamente los autorice.

La reforma iniciada por Lord Devlin ha tenido como consecuencia que la importancia económica de esta partida indemnizatoria en Inglaterra sea, en la actualidad, reducida ${ }^{7}$.

En los Estados Unidos, los daños punitivos tienen una relevancia mayor que en el resto de los países del common law. Su importancia económica es grande debido al quantum de las condenas indemnizatorias y al número de demandas de daños punitivos que se interponen. En el Derecho norteamericano de daños no encontramos un código uniforme para todos los Estados de la Unión en donde se definan los requisitos necesarios de aplicación de esta figura. Tampoco encontramos en los códigos estatales una legislación uniforme, ya que cada uno ha conservado sus particularidades. Se debe recordar que la figura de los daños punitivos es de creación jurisprudencial, así como su desarrollo posterior. Hoy, la judicatura norteamericana es incapaz de realizar una reforma sustancial y homogénea sobre la materia.

Al igual que en otros países, en Norteamérica los daños punitivos recibieron críticas de la doctrina desde el primer momento de su aplicación. Se criticó su naturaleza punitiva - fuera de lugar en la esfera de lo civil-, también la falta de garantías procesales en su aplicación, la confusión entre sus funciones, y la inseguridad jurídica que crean en el Derecho como consecuencia de su impredectibilidad. Las críticas tradi-

${ }^{6}$ Lord Devlin definió a los daños agravados como aquellos que tienen en consideración «(...) los motivos y conducta del demandado, cuando éstos suponen una agravación de la lesión cometida a la víctima. La naturaleza de estos daños no es punitiva, sino compensatoria, y se fijan en la situación del demandado a la hora de establecer el quantum indemnizatorio».

7 Australia es el único país de la Commonwealth en donde la aplicación de los principios establecidos por Lord Devlin ha sido rechazada expresamente. El Tribunal Supremo canadiense ha aceptado la división trazada en Rookes $v$. Barnard entre daños agravados y punitivos o ejemplares y las recomendaciones pero se ha negado a aceptar que los daños punitivos sean reducidos a las categorías que se establecieron en el caso anterior. Las condenas millonarias no son conocidas en Canadá a excepción de un caso de 1989 en el que se concedió un pago de 4.800.000 dólares en concepto de daños punitivos (Walter v. CFTO Ltd. 59 O.R.2d 104 (1987)). 
cionales se han mantenido, pero han surgido otras nuevas. Son estas últimas las que hacen peligrar la continuidad de los daños punitivos. La doctrina norteamericana ha dicho que si estos daños no fuesen una herencia del pasado hoy nadie los crearía. En definitiva, aunque parte de la doctrina los considera una «herencia monstruosa» que debe ser abolida, la mayoría no piden su abolición (tal vez porque no la ven posible) sino su reforma, su adaptación a la situación actual.

Este estado de opinión obligó a los parlamentos estatales a elaborar reformas legislativas. Reformas que incluyen desde el establecimiento de límites máximos en el quantum de las condenas, a la definición de la conducta del agente, creación de nuevas medidas procesales, o su abolición para supuestos concretos - como en el caso de la negligencia médica- En definitiva, lo que los parlamentos estatales hicieron fue responder a las críticas que venía realizando la doctrina norteamericana, aunque de forma limitada y con poco éxito ${ }^{8}$. Estas reformas no han logrado la solución de los problemas que la doctrina denunciaba.

\section{Elementos diferenciadores}

Los daños ejemplares, como consecuencia de su naturaleza punitiva, y por lo tanto excepcional, no se conceden en todas las indemnizaciones de daños. Como hemos apuntado en las páginas precedentes, no existe unanimidad entre los Estados de la Unión, en lo referente a los requisitos necesarios para una condena de daños punitivos. Aun así, podemos extraer algunos elementos generales que los diferencian de la indemnización de daños compensatorios.

\section{Conducta necesaria para la imposición de daños punitivos}

Para determinar si procede una condena punitiva se estudia la naturaleza de la conducta del demandado, y no tanto a la extensión o gravedad del daño sufrido por la víctima. El propósito de esta partida indemnizatoria no es la compensación de la víctima sino el castigo del demandado y la disuasión, por lo que sólo pueden ser concedidos por aquellas conductas para las cuales el remedio es apropiado.

El Profesor Field, en 1876, escribió:

8 La ineficiencia de las reformas se deriva, en parte, del hecho de que algunas ya han sido declaradas inconstitucionales (como es el caso de los límites en la cuantía indemnizatoria). 
«El animus del agente del acto ilícito es una cuestión importante a considerar en estos casos, así como en los casos criminales. El ilícito debe haber sido intencionado, el resultado de un mal proceder, wantonness, o de una indiferencia criminal hacia las obligaciones civiles o hacia los derechos de los otros, de la cual se puede deducir la malice» ${ }^{9}$.

Prosser nos da una descripción más reciente de este tipo de conductas:

«Para una condena de daños punitivos se requiere siempre algo más que la mera comisión de un tort. Deben existir circunstancias agravantes o de ultraje, como el rencor o la "malicia", o un motivo de fraude por parte del demandado, o la falta de atención deliberada hacia los intereses de los otros de tal forma que su conducta pueda ser calificada como wilful o wanton. Existe acuerdo general en que, si falta este elemento, la mera negligencia no es suficiente para condenar a daños punitivos, aun cuando su grado pueda ser caracterizado de $\operatorname{gross}^{10}$ (un término de contenido mal definido, el cual ocasionalmente en unas pocas jurisdicciones se ha ampliado para incluir el elemento de indiferencia consciente hacia las consecuencias, y de esta forma justificar los daños punitivos). Aun menos, por supuesto, pueden imponerse estos daños en contra de una persona que actúa bajo el error inocente de tomar parte en una conducta que en ningún caso constituye un tort $^{11}$.

La conducta es generalmente de dos tipos. Primero, el demandado desea causar el daño sufrido por la víctima, o cree que es casi seguro que de su conducta nacerá un daño ${ }^{12}$. Segundo, el demandado conoce, o debería poder conocer, no sólo que la conducta crea un riesgo irrazonable de producir un daño, sino también que hay una fuerte probabilidad, aunque no una certeza absoluta, de que el daño se producirá. Sin embargo, de forma consciente, continúa ejerciendo su actividad sin tener en cuenta las consecuencias ${ }^{13}$.

9 Field, G.W., A Treatise on the Law of Damages, Mills \& Company Law Publishers, Des Moines (Iowa), 1876, pp. 82-83.

${ }^{10}$ EI término gross negligence se asimila a la culpa lata.

11 Keeton, D., Dobbs, D., Keeton, R. \& Owen, D., Prosser and Keeton on the Law of Torts, 5. ${ }^{a}$ edic., West Publishing Co. (Lawyers edition), St. Paul (Minn.), 1984, pp. 9-10.

12 Ver la definición de las conductas que recoge el AMERICAN LAw Institute, Restatement (Second) of Torts, American Law Institute Publishers, St. Paul (Minn.), 1965, en la sección $8 \mathrm{~A}$.

13 Ver Restatement (Second) of Torts... op. cit., sección 500. 


\section{Acciones en las que se permite una indemnización de daños punitivos}

No existe una regla general para la admisión de una reclamación de daños punitivos; se debe analizar cada cause of action en particular. Dependiendo de las jurisdicciones, hay situaciones en las cuales los daños punitivos no son permitidos, a no ser por la naturaleza agravada de la conducta del demandado, o porque el tribunal considere que la causa subyacente alegada, y probada, es suficiente para que se proceda a analizar la posible responsabilidad por daños punitivos ${ }^{14}$.

Está claro que el incumplimiento contractual, por sí solo, no da lugar a una condena de daños punitivos. Respecto a las acciones basadas en daños a la persona no se encuentra ninguna regla fija que ayude a determinar con anterioridad en qué supuestos cabe pedir una indemnización punitiva y en cuáles no. En relación a las «wrongful death actions» hay que tener en cuenta que estas acciones no son reconocidas en el common law y que son puramente hereditarias en su origen ${ }^{15}$. La regla general es que estas reclamaciones no tendrán lugar, a menos que las leyes confieran tal derecho expresamente ${ }^{16}$.

En la actualidad, el debate sobre la relación que se establece entre una condena penal y la posible condena punitiva en el ámbito de lo civil se ha planteado con fuerza. La pregunta que debemos hacernos no es si caben los daños punitivos en una acción penal, sino si una conducta que ha sido juzgada y castigada penalmente puede también dar lugar a una indemnización de daños punitivos. No es extraño que la conducta que da lugar a una indemnización de daños punitivos también constituya la violación de una ley criminal. La mayoría de los Estados consideran que no hay impedimento para que se condene a daños punitivos aunque, anterior o posteriormente, esa conducta dé lugar a responsabilidad criminal. La razón alegada por los tribunales es que la sanción criminal se impone por el mal que se hizo a la sociedad, y el castigo civil se impone por el mal infligido al demandante particular, y, así, la existencia de la primera no debe afectar a la segunda.

\footnotetext{
14 Para más información sobre este aspecto ver GHIARDI, J.D. \& KIRCHER, J.J., Punitive damages. Law and practice, Illinois, 1991.

15 KeEton, Prosser \& Keeton on Torts... op. cit., p. 945.

16 Ver, por ejemplo: Kennet v. Delta Airlines, Inc 560 F2d 456 (CA1, 1977); Linge's Administrator v. Alaska teadwell Co., 3 Alaska 9 (1906); Mayer v. Rose, 405 A2d 143 (DEI Super 1979); Andis v. Hawhns, 489 NE2d 78 (Ind App 1986); Currie v. Fiting, 375 Mich 440, 134 NW2d 611 (1965); Miller v. Kingsley, 194 Neb 123, 230 Nw2d 472 (1975).
} 
Debido a que uno de los propósitos de los daños punitivos es el castigo, y parece que éste ya se cumple con la sanción penal, algunos tribunales y parte de la doctrina (aunque minoritarios) se han cuestionado la validez de las dos condenas por una misma conducta. Estos tribunales sostienen que se viola la prohibición constitucional en contra de la double jeopardy ${ }^{17}$.

La supuesta violación de double jeopardy no ha prosperado, debido a que la palabra jeopardy en la provisión constitucional es usada en el sentido técnico del common law, y se aplica solamente a las causas criminales de indictment, information y otras (pero siempre causas criminales todas ellas), y los daños punitivos pertenecen al ámbito privado.

En algunas jurisdicciones, se ha utilizado el hecho de que exista una condena penal previa, como prueba para mitigar o reducir la partida indemnizatoria de los daños punitivos ${ }^{18}$.

\section{Relación daños compensatorios y daños punitivos}

Existe abundante jurisprudencia que mantiene la postura de que deben existir daños compensatorios para que el demandante tenga derecho a la partida de daños punitivos ${ }^{19}$. Sin embargo, parece posible que la existencia de daños nominales (suma «trivial» de dinero con la que se indemniza al litigante que ha establecido su causa de acción, pero que no ha probado su derecho a daños indemnizatorios) sea suficiente para que se admita la demanda, sobre todo en aquellas jurisdicciones en las que la función compensatoria de los daños ejemplares es reconocida $^{20}$.

La relación que existe entre los daños punitivos y los daños compensatorios aparece también al tratar el tema del quantum de la indemnización. Algunos tribunales y parte de la doctrina han considerado que

17 Se trata de la prohibición de segundo procesamiento respecto de un mismo delito.

18 Ver: Saunders v. Gilbert (1911) 156 NC 463, 72 SE 610; White v. Taylor (1981) 157 Ga App 328, 277 SE2d 321; Tuttle v. Raymond (1985, Me) 494 A2d 1353, 58 ALR4th 859; Anderson v. Amundson (1984 Minn App) 345 NW2d 895; Edwards v. Wessinger (1903) 65 SC 161, 43 SE 518.

19 Ver: Lipinski v. Title Ins. Co., 202 Mont 1, 655 P2d 970 (1982); Spenser v. Steinbrecher, 152 W Va 490, 164 SE2d 710 (1968); O'Brien v. Snow, 215 Va 403, 210 SE2d 165 (1974); Belleville v. Davis, 262 Ore 387, 498 P2d 744 (1972); Fowler v. Mantooth, 683 SW2d 250 (Ky 1985).

20 Ver: Gulf Atlantic Life Ins. Co. v. Barnes, 405 So2d 916 (Ala 1981); Haugabrook v. Taylor, 225 Ga 317, 168 SE2d 162 (1967); Fowler v. Mantooth, 683 SW2d 250 (Ky 1984); Compton v. Williams Bros. Pipeline Co., 499 SW2d 795 (Mo 1973). 
debe existir una relación entre ambos conceptos; es decir, que el quantum de los daños punitivos debe ser proporcional al de los daños compensatorios. Esta postura ha sido atacada duramente porque se considera que es altamente lesiva para las funciones punitivas y disuasorias.

\section{Funciones o justificaciones ${ }^{21}$}

\section{Función compensatoria}

En los orígenes de los daños punitivos se ve clara la intención de utilizarlos como forma de compensar a la persona lesionada por aquellas pérdidas que el Derecho no reconocía, por ejemplo los daños morales. En la actualidad, esta función no se sostiene puesto que la amplia categoría de pain and suffering 22 comprende muchos (si no todos) de aquellos daños que en el pasado no eran indemnizables y ahora sí lo son. Además, es de aplicación en el Derecho anglosajón, al igual que en nuestro Derecho, el principio de restitutium in integrum bajo el cual, en teoría, todas las pérdidas que sufra la víctima como consecuencia de un acto ilícito serán compensadas por medio de los daños compensatorios.

La función compensatoria ha dejado de ser alegada en los tribunales y no aparece en la mayoría de los códigos estatales ${ }^{23}$. La razón de ser de esta función, si bien sobrevive de forma marginal, se encuentra en los honorarios de los abogados. A la hora de determinar el quantum indemnizatorio, el juez o jurado no consideran indemnizables los gastos del proceso (más concretamente los honorarios de los abogados) por lo que esta partida correrá a cargo de cada una de las partes del

21 ElLIS, «Fairness and Efficiency in the Law of Punitive Damages», en South California Law Review, vol. 56, 1982, pp. 1-3. Ellis consideró que eran siete las funciones de estos daños, aunque podían ser reducidas a dos:

1. Castigo del demandado concreto.

2. Disuasión del demandado concreto.

3. Disuasión de otros que actúan de manera similar.

4. Preservar la paz social.

5. Incentivar el cumplimiento de la ley civil.

6. Compensación adicional para las víctimas por sus pérdidas intangibles.

7. Pago de los gastos de abogado del demandante.

$22 \mathrm{El}$ «pain and suffering» anglosajón comprende el dolor y sufrimiento de la víctima como consecuencia del daño.

${ }^{23}$ La excepción la encontramos en Connecticut, Georgia, Michigan y New Hampshire, en donde aunque se usan los términos daños ejemplares o punitivos, su naturaleza es claramente compensatoria. 
proceso, independientemente del resultado del mismo. A favor de los daños punitivos se dice que gracias a ellos llegan a los tribunales casos que de otra forma no lo habrían conseguido - debido a la escasez de medios del demandante- y que es conveniente que sean juzgados. Por ejemplo, en el Estado de Connecticut la cuantía de los daños punitivos se limita a los gastos del proceso del demandante, menos los impuestos.

\section{Función de castigo o punitiva}

Los daños punitivos, como su nombre indica, buscan castigar al culpable que actuó de forma maliciosa, temeraria, con grave descuido hacia los derechos de los otros ${ }^{24}$. Esta función, al igual que la anterior, ha acompañado a los daños punitivos desde su origen. Si bien, y a diferencia de la función compensatoria, se ha mantenido en el tiempo ${ }^{25}$, a pesar de ser la causa del mayor número de críticas.

Las críticas se basan en la distinción clásica entre el Derecho civil y el penal. El Derecho civil — se dice- es claramente compensatorio, no punitivo. El espíritu que anima al Derecho de daños es la compensación de la víctima, colocar a la víctima en una posición igual que la que ocupaba antes del accidente. Para castigar al culpable está el Derecho penal, en donde se encuentran mayores garantías procesales que en el Derecho civil.

El profesor Morris ${ }^{26}$, en 1931, llegó a la conclusión de que los daños compensatorios no están exentos de un fin punitivo. Si no, no se explicaría por qué en un Derecho basado en la responsabilidad por culpa se indemniza al demandante a costa del demandado, cuando en el actuar de éste no ha habido intención de lesionar. Se indemniza a la

24 Ver Wangen v. Ford Motor C., 97 Wis2d 260, 279-80, 294 NW2d 437(1980):

«Aunque continúa la controversia sobre la doctrina de los daños punitivos en el siglo veinte, y aunque algunos han cuestionado si el Derecho de daños - el cual ha sido lesionado para compensar al demandante lesionado- debería también cumplir con las funciones del Derecho penal, por ejemplo, castigar al demandado con el propósito de disuadirle a él y a otros de posteriores ofensas, este tribunal ha dicho de forma consistente y frecuente que el castigo y la disuasión son consideraciones importantes en la ley de Wisconsin.»

25 Delaware es la única jurisdicción en la que el castigo es el único propósito en la imposición de los daños punitivos. El Tribunal de Delaware estableció en Riegel v. Aastad, 272 A2d 715, 718 (del 1970) que: «Los daños punitivos o ejemplares no se indemnizan como forma de recompensar por la lesión, sino como forma de castigo al agente ilícito cuando el acto ilícito fue cometido "wilfully or wantonly"».

26 Morris, C., «Punitive damages in Tort Cases», en Harvard Law Review, 1931, p. 1.174 . 
víctima a costa del demandado, en primer lugar por el principio retributivo, pero también para disuadirle de posibles actuaciones posteriores. Morris llegó a la conclusión de que el Derecho civil, aunque inspirado principalmente en principios compensatorios, también contiene elementos de castigo y disuasión. Para este autor la función compensatoria por sí sola no justifica que la indemnización descanse en el demandado declarado responsable.

La doctrina que defiende los daños punitivos alega que el Derecho penal no persigue todos aquellos casos en los que una persona actúa con una conducta cercana o similar a la criminal. Es decir, que sirven para castigar conductas cuasicriminales que no son castigadas por el Derecho penal. La respuesta de los que se oponen a estos daños es que si la conducta de una persona no constituye un crimen no merece ser castigada como tal ${ }^{27}$. En el supuesto de que constituyese un crimen, entonces un tribunal penal es el foro más razonable para que sea juzgada.

En suma, se les critica duramente porque suponen la introducción de un fin punitivo en un Derecho de tort cuyo único fin, en principio, debe ser el compensatorio.

\section{Función disuasoria ${ }^{28}$}

La sociedad actual tiende a buscar la seguridad en todos los ambientes en que se mueve el individuo. Esta tendencia ha llevado a que la compensación de la víctima no sea la única función del Derecho de daños. Se busca disuadir a la persona responsable del daño, y a otros ${ }^{29}$, para que no tome parte en el futuro en actividades o comportamientos que lesionen a un tercero. La función disuasoria no va, únicamente, dirigida al demandado del caso concreto, sino que pretende ser un mensaje dirigido a la sociedad.

27 Ver Defense Research Institute, The Case Against Punitive Damage, 1969, p. 10.

28 El Tribunal Supremo de Idaho en Jolley v. Puregro Co., 496 P2d 939, 945-46 (Idaho 1972) dijo: «Nosotros sentimos que el tribunal, en estos casos civiles, debería estar motivado principalmente por el propósito de disuasión y no por el propósito de castigo. En otras palabras, la valoración de los daños punitivos debería estar guiada por el deseo del tribunal o del jurado de asegurar, en la medida de lo posible, la imposición de una pena económica, de tal forma que conductas similares no ocurran en el futuro. El castigo debe dejarse para el Derecho penal».

Sin embargo, la gran mayoría de las jurisdicciones consideran que el propósito es doble: el castigo y la disuasión.

${ }^{29}$ Para los autores del Análisis Económico del Derecho existen dos tipos de disuasión: disuasión específica y general. Disuasión específica hace referencia al individuo en concreto, al que cometió el acto ilícito que está siendo juzgado. Disuasión general hace referencia a la sociedad, a los otros individuos que estén en situaciones similares. 
El Tribunal Supremo de Texas, en 1984, aclaró las bases teóricas a aplicar en estos supuestos en el Estado de Texas ${ }^{30}$. El caso en cuestión trataba una demanda por accidente en la que al demandado, fallecido, se le había encontrado un nivel de intoxicación etílica en la sangre doble del permitido por la ley. Se alegó que ya que el fin de los daños punitivos era el castigo, y el demandado no podía ser castigado nunca más en esta tierra, por haber fallecido en el accidente, se perdía la base para sentenciar a estos daños. El tribunal reconoció que el castigo del que actúa ilícitamente es uno de los propósitos, pero otro propósito igualmente importante es el de servir como ejemplo a la población, por lo que la indemnización de daños punitivos era apropiada en este caso.

Concluyó con una definición de estos daños:

«"Daños ejemplares" significa la cantidad que ustedes pueden conceder de forma discrecional y como ejemplo para el bien del público, en el interés de la sociedad de disuadir la comisión de ilícitos similares» ${ }^{31}$.

El apoyo a esta función - y por lo tanto a los daños punitivos- ha venido en los últimos tiempos de manos del Análisis Económico del Derecho $^{32}$. Un grupo importante de autores de la escuela de Chicago

30 Ver Hofer v. Lavender, 679 S.W.2d 470 (Tex. 1984).

31 Hofer v. Lavender, 679 SW2d 470, 471 (Tex 1984).

${ }^{32}$ Los daños punitivos han sido tratados desde el punto de vista del análisis económico del Derecho en múltiples artículos:

ABRAHAM, K. Y JEFFRIES, J., «Punitive damages an the rule of law: the role of the defendant's wealth», en Journal of Legal Studies, vol. 18, 1989, pp. 415-425; BosToN, G.W., «Environmental torts and punitive damages», en Journal of Products Liability, vol. 14, 1992, pp. 1-39; ChAPMAN, B. Y TREBILCOCK, M.J., «Punitive damages: detterence in search of a rationale», en Alabama Law Review, vol. 40, 1989, pp. 741-829; COOTER, «Prices and sanctions», en Columbia Law Review, 1984, pp. 1.523 y ss.; «Economic analysis of punitive damages», en South California Law Review, vol. 56, 1982, pp. 79-101.

ElLIS, D.D., «Faimess and Efficiency in the Law of Punitive Damages», en South California Law Review, vol. 56, 1982, pp. 1 y ss.; GHIARDI \& KoEHN, «Punitive damages in strict liability cases», en Marq. Law Review, vol. 61, 1977, pp. 245 y ss.; JoHnston, «Punitive liability: A new paradigm of efficiency in tort law», en Columbia Law Review, vol. 87, 1987, pp. 1.385 y ss.; MANN, K., «Punitive civil sanctions: the middleground between criminal and civil law», en Yale Law Journal, vol. 101, 1992, pp. 1.795-1.873; Owen, D.G., «Problems in assessing punitive damages against manufactures of defective products», en University of Chicago Law Review, vol. 49, 1982, pp. 1-60; «Punitive damages in Product Liability Litigation», en Michigan Law Review, vol. 74, 1976, pp. 1.257 y ss.; «Civil punishment and the public good», en S. Cal. Law Review, vol. 56, 1982, pp. 103 y ss.; «Deterrence and Desert in Tort: A Comment», en California Law Review, vol. 73, 1985, pp. 665-676; RoBinson \& KANE, «Punitive damages in the products case», en Pepperdine Law Review, 1979, pp. 139 y ss.; Sales, J.B. \& Cole, K.B., «Punitive Damages: A Relic that has Outlived its Origins», en Vandervilt Law Review, vol. 37, 1984, pp. 1.117-57.

Schilit, H.M., «A model to assess the economic consequences of punitive damages», en Journal of Products Liability, vol. 14, 1992, pp. 265-275. 
mantienen la teoría de que los responsables de la lesión deben soportar los costes totales de su actividad, y que éstos no son siempre iguales a los daños compensatorios, por lo que en ciertos supuestos es recomendable una condena de cuantía superior a los daños reales sufridos por el demandante. A favor de la función disuasoria se dice que si es efectiva, llevará a unos niveles óptimos de seguridad. Niveles que se lograrían condenando a una gran suma de dinero, de tal fonna que para el demandado en ningún momento resulte rentable la comisión del acto ilícito. Se dan supuestos, principalmente en el mundo de la empresa, en los que para la persona física o jurídica es más rentable económicamente la realización del acto ilícito y el posterior - y posible- pago de la condena a daños compensatorios, que la no realización de la actividad.

La pregunta que se debe hacer es si nuestra sociedad busca una disuasión total o una disuasión eficiente. Parece posible que una condena indemnizatoria superior a los daños reales sufridos por la víctima tenga cierto efecto disuasorio, especialmente en las grandes empresas. Lo que no está claro es si el nivel disuasorio que se alcanza es un nivel eficiente o si por el contrario este tipo de condenas lleva a no tomar parte en actividades, que aunque contienen un componente de riesgo, son beneficiosas para la sociedad ${ }^{33}$.

No existen datos empíricos sobre el efecto de esta función en la población. Parte de la doctrina considera que con la condena de daños punitivos no se consigue ningún efecto disuasorio. Si fuera así, el número de accidentes por productos defectuosos, por ejemplo, habría descendido en la sociedad norteamericana, lo cual no parece haber ocurrido. Se les niega efecto disuasorio, porque no contienen ninguno de los elementos que incrementan la función de disuasión de la pena: rapidez de acción, certidumbre y magnitud de la pena. Hay muchos factores que erosionan el fin disuasorio de los daños punitivos, y entre ellos los más alegados son el seguro y la responsabilidad del empleador.

Aún en el supuesto de que admitamos que estos daños cumplen una función eficiente de castigo y disuasión, ello sólo justificaría que al demandado se le imponga una condena superior a los daños compensatorios, pero en ningún caso justificaría que esa cantidad, que excede de lo meramente compensatorio, se entregue a la víctima.

Algunas de las reformas legislativas que tuvieron lugar en la década de los ochenta crearon límites en la cuantía que podría conceder el jurado bajo este concepto. Los límites hacían referencia, en algunos casos, a los honorarios de los abogados, al doble de la condena compen-

$33 \mathrm{Al}$ tratar este tema se suele poner el ejemplo de la investigación en el campo de la farmacología, el cual se puede ver altamente frenado por una disuasión excesiva. 
satoria o a una cantidad determinada que actuaba como límite máximo. Establecer un límite fijo sobre la cuantía va en contra del fin disuasorio, ya que no será igual la cantidad necesaria para disuadir a una gran empresa de automóviles, por ejemplo, que la necesaria para disuadir a un particular o persona física.

Esta función ha recibido abundantes críticas por parte de la doctrina, no tanto por sí misma, sino por su falta de efectividad y su puesta en práctica por medio de los jurados. El profesor Elliot se pregunta si tiene sentido en un Derecho de daños moderno, cuya intención es la de crear incentivos eficientes para la seguridad, el dar al jurado un poder ilimitado y discrecional para condenar a daños punitivos. Este autor llega a la conclusión de que la indemnización de daños punitivos no tiene sentido hoy en día, y además, piensa que pueden llevar a reducir los incentivos económicos de seguridad ${ }^{34}$. Se considera que los jurados no están cualificados para determinar el quantum de una condena punitiva. La función disuasoria no se puede cumplir si los daños punitivos no son predecibles. La concepción moderna del Derecho de la responsabilidad civil como sistema regulador de conductas depende de su capacidad de ser predecido, así las acciones tomadas ex post en un caso deben poder ser utilizadas por otros como incentivos ex ante para guiar futuros comportamientos. De acuerdo con un estudio de 1987 del Rand Institutte for Civil Justice realizado en Illinois y California «(...) la incidencia de las demandas de daños punitivos (...) y la cantidad de dinero (...) concedido con fines punitivos han aumentado sustancialmente durante los años 1960 a $1984^{35}$. Un estudio de la Conferencia Board sobre los efectos de las demandas de responsabilidad de productos defectuosos en empresas refleja que suponen una parte relativamente pequeña en la organización y economía de las grandes empresas. La respuesta más común de las empresas fue la de aumentar ligeramente el precio de sus productos. Menos de una tercera parte de las empresas declaró haber hecho cambios en los diseños de seguridad de sus productos como consecuencia de las demandas interpuestas. De hecho, el efecto económico que las demandas han tenido en las empresas es proporcionalmente pequeño puesto que muchos de los veredictos del jurado son reducidos con posterioridad por el juez al considerarlos excesivos.

En suma, el efecto preventivo no se cumple porque los procesos civiles son por lo general lentos, las cantidades concedidas impredeci-

34 Elliot, D., «Why Punitive Damages don't deter corporate misconduct effectively?», en Alabama Law Review, vol. 40, 1989, pp. 1.053 y ss.

35 Paterson M., S. Sarma \& M. Shanley, «Punitive damages empirical findings», RAND, The Institute for Civil Justice, 1987. 
bles, y los jurados no están preparados para realizar esta función de forma eficiente. En una encuesta que se realizó a los jueces del Tribunal Supremo del Estado de California se encontró que están a favor de la institución del jurado para las demandas civiles ordinarias, pero respecto a los daños punitivos, los jueces dejaron claro que tenían sus dudas sobre las decisiones del jurado tanto al otorgar los daños punitivos, como en la determinación de su cantidad.

\section{Problema actual: Daños punitivos v. Responsabilidad por Productos defectuosos}

Desde sus orígenes a finales de los años sesenta, el remedio de los daños punitivos en los casos de product liability ${ }^{36}$ ha sido, según el profesor Prosser, el «campo de batalla de la teoría social» ${ }^{37}$.

La condena de estos daños a un único demandado por la fabricación o distribución de un producto a un gran número de consumidores ha creado problemas nuevos para la doctrina y la jurisprudencia norteamericana.

Normalmente, las demandas de daños punitivos surgen de un acto ilícito único que vincula a dos partes, haciendo posible que el jurado llegue a una condena, más o menos, apropiada sin tener que considerar la posibilidad de condenas adicionales por demandas futuras. En los casos de accidentes en masa o de productos defectuosos, la responsabilidad no se limita a una lesión única, sino que existen múltiples lesionados como consecuencia de un acto único del demandado. Esta situación da lugar a varios problemas nuevos incluyendo la extensión del castigo del demandado por un único acto o conducta, o si el jurado deberá ser informado de las condenas pasadas y futuras, o la forma en la que la condena debe ser distribuida entre las víctimas. La complejidad de los casos de product liability, la dificultad de discernir la wrongfulness de un proceso de decisión empresarial, y el problema de valorar la riqueza de una moderna empresa son factores que distinguen estos casos de los comunes del Derecho de daños.

Ha existido un amplio debate en la doctrina sobre si son compatibles los daños punitivos con los casos de product liability ${ }^{38}$.

36 Responsabilidad por productos defectuosos.

37 Ver Prosser, W., Handbook of the Law of Torts, St. Paul West Publ. Co., 1971, p. 3.

${ }^{38}$ Algunos artículos reflejo de este debate son:

OwEN, «Punitive damages in product liability litigation», en Michigan Law Review, vol. 74, 1974, pp. 1.257 y ss.

TOZER, «Punitive damages and product liability», en Ins Counsel Journal, vol. 39, 1972, pp. 300 y ss.; Fulton, «Punitive damages in product liability cases», en Forum, vol. 15, Fall 1979, pp. 117 y ss. 
De los pocos casos que han tratado el problema de la posible incompatibilidad de los daños punitivos, bajo la teoría de la negligencia en los casos de product liability, se puede concluir que si de la conducta del demandado se deduce un estado de ánimo o comportamiento que transciende la ordinary negligence, los tribunales condenarán a daños punitivos debido al carácter extraordinario de la conducta del demandado, a pesar de la teoría de responsabilidad cuasi objetiva subyacente a los product liability ${ }^{39}$.

No ha existido ningún caso que haya sentenciado a daños punitivos en base únicamente a la breach of warranty. Sí hay condenas de daños punitivos en aquellos casos en los que se alega breach of warranty y negligence $e^{40}$.

Aunque de forma no concluyente, las sentencias estudiadas apuntan la idea de que se permiten los daños punitivos si se prueba la existencia de una conducta indeseable. Si el tribunal está convencido de que el fabricante necesita ser disuadido de comportamientos irresponsables condenarán a daños punitivos aunque la cause of action tradicional no lo permita ${ }^{41}$.

El Tribunal Supremo de Florida estableció el modelo de conducta en Johns-Manville Sales Corp v. Janssens ${ }^{42}$ :

«Las bases legales para la imposición de daños punitivos se dan en los casos de product liability, en los que se pruebe que el fabricante tenía conocimiento de que su producto era inherentemente peligroso para las personas o la propiedad y que si lo mantenía en el mercado probablemente causaría lesiones o muerte, pero, de todas formas, continuó con la fabricación del producto sin realizar modificaciones que eliminasen el peligro o no informó adecuadamente sobre su peligrosidad.»

La condena de daños punitivos en los casos de strict liability ${ }^{43}$ ha sido criticada porque se considera que es legalmente inconsistente, tanto en la teoría como en sus efectos prácticos. En teoría, una acción de strict liability libera al demandante de la carga de la prueba de la negligencia del demandado y protege contra las defensas legales de ciertos

39 Ver Ghiardi \& Kircher, Punitive Damages... op. cit., cap. 6, también Vollert v. Summa Corp. 389 F. Supp 1348 C.D: Hawaii (1975) y Drayton v. Jiffe Chemical Corp. 395 F. Supp. 1081 CND Ohio (1975).

40 Ver: Cantrell v. Amarillo Hardware Co., 226 Kan 681, 602 P2d 1326 (1979) y Hafner v. Guerlain, Inc 34 App. Div. 2d 162, 310 NYS2d 141 (1970).

41 Ver Owen, Punitive Damages in Product Liability..., cit., p. 1.257. Ver también Cochran v. Rockwell International Corp, 564 F Supp 237 (ND Miss 1983).

42463 So2d 242, 249 (Fla App 1984).

${ }^{43}$ La strict liability es similar, aunque con matices, a nuestra responsabilidad objetiva. 
fabricantes. En estas acciones la responsabilidad del demandado nace no de su culpabilidad, sino de la prueba de que el producto era defectuoso o irrazonablemente peligroso ${ }^{44}$. Sin embargo, los daños punitivos están basados en la prueba de una culpa agravada, y la conducta del fabricante es el único determinante de la responsabilidad ${ }^{45}$, por lo que parece que ambas figuras son incompatibles.

\section{Roginsky v. Richardson-Merrell/Toole v. Richardson-Merrell}

La mayoría de la doctrina cita a 1967 como el año en que comenzó el debate ${ }^{46}$. En este año se juzgaron dos casos que trataban supuestos idénticos y que se decidieron con un período de nueve semanas entre ellos. Estos dos casos reflejan los puntos de vista contrarios sobre la cuestión. El Tribunal de Apelación de California en Toole v. Richardson-Merrell, Inc. ${ }^{47}$ declaró que una condena de daños punitivos podía ser apropiada en un supuesto de strict liability, mientras que en Roginsky v. Richardson-Merrel ${ }^{48}$ el tribunal adoptó la postura contraria.

El demandado Richardson-Merrell distribuyó un fármaco (que hacía descender el nivel de colesterol en la sangre), llamado MER/29, entre aproximadamente 400.000 personas. Esta droga provocó cataratas en algunos de sus consumidores. La prueba presentada en el juicio de-

44 Restatement (Second) of Torts... op. cit., sección 402A (1965):

«Special Liability of Seller of Product for physical harm to User or Consumer:

(1) One who sells any product in a defective condition unreasonably dangerous to the user or consumer or to his property is subject to liability for physical harm thereby caused to the ultimate user or consumer or to his property, if

(a) the seller is engaged in the business of selling such a product, and

(b) it is expected to and does reach the user or consumer without sustantial change in the condition in which it is sold.

(2) The rule stated in Subsection (1) applies although and

(a) the seller has exercised all possible care in the preparation and sale of his product,

(b) the user or consumer has not brought the product from or entered into any contractual relation with the seller.»

45 EI primer tribunal que trató explícitamente con el argumento de «inconsistencia» fue el Eastern District Federal Court en Wisconsin (Drake v. Wham-O. Mfg. Co., 373 F. Supp 608 (ED Wis 1974)). Este tribunal declaró que la imposición de daños punitivos no podía basarse en la mera negligencia y por lo tanto un supuesto de strict liability, por sí solo, no podía soportar una demanda de daños punitivos. Pero mantuvo que una demanda por strict liability si estaba acompañada de algo más permitiría la imposición de daños punitivos.

46 El primer caso es Fleet v. Hollen Kemp (52 Ky 175 (1852)).

47251 Cal App. 2d 689, 60 Cal Rptr. 398 (1967).

48378 F2d 832 (CA2, 1967). 
mostró que el demandado conocía el peligro potencial existente antes de la puesta a la venta del MER/29. En 1960, antes de que el producto saliese a la venta, Richarson-Merrell había realizado seis pruebas que demostraron que era posible que la droga tuviera efectos secundarios peligrosos. La empresa alteró los resultados de las pruebas en los informes presentados a la Food and Drug Administration, y el MER/29 se anunció como «virtualmente» no tóxico y libre de efectos secundarios.

Durante el período de tiempo que la droga estuvo en el mercado, la empresa recibió informes de médicos e investigadores independientes que afirmaban la existencia de ciertos efectos secundarios en los consumidores. Sin embargo, la droga continuó a la venta. Sólo después de una visita sorpresa de los oficiales de la FDA a los laboratorios y la posterior confiscación de las pruebas realizadas sobre animales, el demandado retiró el producto del mercado.

La MER/29 había sido administrada a 400.000 personas y se informó de 490 casos de cataratas. Las ventas aportaron un beneficio de 7.000.000 de dólares a la empresa.

El trial court en Roginsky v Richardson-Merrell condenó a 100.000 dólares por daños punitivos, pero el second circuit casó el veredicto porque la prueba no era suficiente para condenar a daños punitivos. El Juez Friendly justificó la decisión en base a argumentos de orden público. En su opinión, en la producción y distribución de productos en masa cabe la posibilidad de que existan cientos de demandantes, y esto puede dar lugar a que el castigo impuesto al demandado sea excesivo; tal vez arruinando la vida económica de la empresa y por lo tanto afectando negativamente a la sociedad como un todo. El argumento del Juez Friendly, en contra de la imposición de daños punitivos en los casos de responsabilidad por productos defectuosos, puede ser resumido en:

1. Las condenas múltiples de daños punitivos pueden tener como resultado que la responsabilidad del demandado sea superior a la pena económica máxima criminal.

2. No existe un método, en la práctica, para que el tribunal evite el problema del exceso de responsabilidad.

3. La condena de daños compensatorios y las penas criminales deberían servir como disuasión eficiente para los fabricantes; las primas de los seguros a cargo de los fabricantes se elevarían y su reputación profesional declinaría.

4. El coste de esta disuasión adicional deberá ser soportado por el público en general, puesto que adoptará la forma de precios más altos de los productos y la quiebra de las empresas. 
5. Es injusto castigar a un accionista inocente cuando la culpa es del personal ejecutivo, el cual está fuera del control del tribunal.

Dos meses después de esta sentencia, un tribunal de Califormia rechazó el razonamiento de Roginsky en un supuesto de hecho virtualmente idéntico ${ }^{49}$. El jurado condenó a 500.000 dólares por daños punitivos en Toole, pero el trial court redujo la condena a 250.000 dólares. El Tribunal de Apelación mantuvo la condena punitiva. En este segundo caso se consideró probado que ${ }^{50}$ :

1. Merrell tuvo conocimiento del defecto mediante las pruebas realizadas en animales. En una de ellas 20 de 24 ratas se quedaron ciegas.

2. Importantes razones económicas hicieron que Merrell mantuviera el producto en el mercado el mayor tiempo posible.

3. El demandado no hizo nada para remediar el defecto.

4. Merrell intentó ocultar el defecto en los informes que aportó a la FDA y en su material de promoción.

5. La conducta de la empresa superó en mucho la conducta normal de las empresas de farmacología.

6. No quedó claro si la droga hacía descender el nivel de colesterol o no. Aunque el tribunal no declaró a la droga como inefectiva, su opinión da la impresión de que no producía ningún beneficio en los usuarios.

7. El demandado no investigó, experimentó, o hizo ningún intento para encontrar la solución al problema.

Desde 1967, fecha en la que se juzgaron estos dos casos, la polémica se ha mantenido viva. A continuación analizaremos otro precedente judicial con el fin de aclarar, en la medida de lo posible, una cuestión en la que abundan las opiniones dispares tanto de la doctrina como de la jurisprudencia.

\section{Grimshaw v. Ford Motor Co. ${ }^{51}$}

En noviembre de 1972, Lilly Gray conducía un automóvil modelo Ford Pinto por la autopista. Después de repostar gasolina, el carburador del coche, saturado de combustible, se hundió, ocasionando la apertura

\footnotetext{
49 Toole v. Richardson-Merrell 251 Cal App 2d 689, 60 Cal Rprt 398 (1967).

${ }^{50}$ GHIARdi \& KirCher, Punitive Damages... op. cit, p. 86.

51 App. 174 Cal Rptr 348.
} 
de la cámara del flotador. El motor se inundó y el coche se paró. Otro automóvil que circulaba en la misma dirección colisionó con la parte trasera del Ford Pinto, irrumpiendo este último en llamas. La conductora del Ford Pinto, Lilly Gray, sufrió quemaduras mortales y Richard Grimshaw, un pasajero de 13 años de edad, sufrió quemaduras graves que desfiguraron permanentemente su rostro y todo su cuerpo. Grimshaw y los herederos de Lilly Gray demandaron a Ford, y a otros.

Después de un juicio con jurado que duró 6 meses, a Grimshaw se le indemnizó con 2.516.000 de dólares en concepto de daños compensatorios y 125 millones de dólares en concepto de daños punitivos. Los herederos de Lilly Gray recibieron 559.680 dólares en concepto de daños compensatorios. Como consecuencia de la apelación por parte de Ford, a Grimshaw se le requirió para que devolviese todo menos 3,5 millones de los daños punitivos como condición para oponerse a la apelación. La apelación de Ford se basaba, entre otras consideraciones, en que aún en el supuesto de que los daños punitivos fuesen adecuados en este caso, el quantum de la condena era excesivo.

En el juicio resultó probado que ciertos directivos de Ford, gracias a las pruebas que se habían realizado sobre el coche, conocían la fragilidad del tanque de gasolina del Ford Pinto en caso de una colisión a velocidades superiores a las 20 millas por hora. Ford había realizado prototipos para determinar la resistencia del sistema de gasolina en los supuestos de colisiones traseras. Estas pruebas se llevaron a cabo también para comprobar si el coche cumplía los requisitos de la regulación federal, la cual requería que todos los automóviles que se fabricasen en 1972 (año de fabricación del coche) fuesen capaces de soportar un impacto a 20 millas por hora, sin un vertido sustancial de gasolina. Los directivos de Ford conocían que después del 1-1-1973 el límite de resistencia se elevaría a 30 millas por hora. Las pruebas de choque revelaron que el sistema de gasolina del Ford Pinto no cumplía el límite de resistencia de 30 millas por hora. En al menos una de las pruebas, la gasolina derramada pasó al compartimiento del conductor, (igual situación que la que tuvo lugar en el accidente comentado). Se comprobó que vehículos con el tanque de gasolina instalado encima de la rueda trasera y no debajo, como era el caso, pasaban la prueba a una velocidad de 31 millas por hora.

También resultó probado que las deficiencias en el diseño podían haber sido remediadas a un coste de 15,30 dólares por coche, con lo que el tanque de gasolina habría sido seguro en un supuesto de colisión a velocidades de hasta 38 millas por hora.

Se presentaron como pruebas: primero, un informe de Ford de 1971 recomendando que se tomaran medidas antes de la promulgación de los 
requisitos federales sobre la integridad del sistema de gasolina para lograr un ahorro en costes. Segundo, un informe (conocido como el «Chiara memorandum») de febrero de 1971 en el que se reflejaba que el coste de colocar el tanque sobre el eje con una capa protectora era de 10 dólares.

En Grimshaw, el Tribunal tuvo ocasión de pronunciarse sobre los propósitos primarios de los daños punitivos, los cuales, en opinión del tribunal, son el castigo y la prevención de conductas como la del actor y la de otros:

«Para el tort tradicional, no comercial, los daños compensatorios por sí solos pueden servir como elemento de prevención efectivo en contra de futuras conductas lesivas, pero en los torts relacionados con el comercio, el fabricante puede encontrar más beneficioso considerar los daños compensatorios como parte de los costes del negocio, en lugar de remediar el defecto (...). Los estándares de seguridad administrativos y el Derecho penal han fracasado en la labor de proporcionar una protección adecuada al consumidor en contra de la fabricación y distribución de productos defectuosos. Los daños punitivos son el remedio más efectivo de protección del consumidor en contra de la fabricación en masa de productos defectuosos. Estos proveen de un motivo para que los particulares hagan valer la ley y recuperen los gastos que esto les ocasiona, que pueden ser considerables y no recuperables por otros medios.»

El tribunal concluyó:

«Nosotros no encontramos impedimentos legales para la aplicación de la sección 3.294 del Código civil a un caso de strict liability basado en un diseño defectuoso.»

La alegación por parte de Ford de que la responsabilidad potencial por daños punitivos en futuras demandas por el mismo defecto de diseño puede dar lugar a una violación del derecho al due process tampoco fue admitida. En opinión del tribunal esta afirmación lleva a la lógica conclusión de que nunca puede condenarse a un fabricante de productos en masa a daños punitivos. Sin embargo, el tribunal reconoció que las condenas múltiples podrían ser un problema, pero que la mera posibilidad de una condena futura en un caso diferente no suponía base suficiente para rechazar la demanda en este supuesto, sobre todo cuando ésta ya ha sido reducida en su quantum.

La cantidad concedida por el jurado, en concepto de daños punitivos, fue de 125 millones de dólares. Posteriormente se redujo a 3,5 millones de dólares. Ford alegó que la condena era excesiva, y que no guardaba relación alguna con las cantidades concedidas en otros casos 
de daños punitivos en California. La respuesta del tribunal fue clara. Para determinar cuándo una condena en daños punitivos es o no excesiva, no se debe comparar con condenas anteriores, aunque procedan del mismo tribunal. En opinión del tribunal, una fórmula cuantitativa con una certeza matemática es manifiestamente imposible, a la vez que indeseable. La actuación correcta es la de analizar las circunstancias del caso en concreto; las cuales según el tribunal son:

a) Grado de reprensión de la conducta del demandado. Sobre lo que dijo «(...) la conducta del directivo de Ford fue altamente censurable».

b) Riqueza o capital del demandado: «La indemnización reducida no fue excesiva teniendo en cuenta la riqueza del demandado y el tamaño de la indemnización compensatoria».

c) Cantidad concedida en concepto de daños compensatorios.

d) Cantidad que podría tener efectos preventivos para conductas similares del demandado o de otros: «Tampoco se puede considerar que la indemnización fue excesiva a la luz de su propósito disuasorio. Una indemnización que sea tan pequeña como para poder ser considerada como parte de los costes del negocio no tendría efectos disuasorios. Una indemnización que afecte a los precios de los productos de la compañía y por lo tanto tenga efectos sobre su ventaja competitiva servirá como disuasorio».

\section{Características comunes}

Los casos de product liability en los que se permite la condena de daños punitivos poseen unas características comunes que los distinguen de los casos típicos de responsabilidad por productos defectuosos.

\section{a) El DEMANDADO CONOCÍA LA EXISTENCIA DEL DEFECTO}

Un estudio de la jurisprudencia nos lleva a la conclusión de que el demandado debe tener conocimiento del defecto del producto y del daño potencial para que la condena de daños punitivos sea apropiada. Este conocimiento se alcanza con las pruebas que el fabricante o distribuidor realizó antes de poner el producto en el mercado o por medio de informes de accidentes sufridos por los consumidores posteriores a la venta del producto. 
b) El DEMANDADO RECIBÍA IMPORTANTES BENEFICIOS ECONÓMICOS DE LA FABRICACIÓN Y VENTA DEL PRODUCTO

No todos los tribunales permiten que se aporte prueba sobre la riqueza del demandado, o el beneficio obtenido por la venta o distribución del producto defectuoso. Los tribunales que han admitido la prueba de los beneficios económicos del demandado lo han hecho con dos propósitos: primero, para probar la indiferencia del fabricante hacia el consumidor; segundo, para calcular el quantum de los daños, ya que para que resulten punitivos deben absorber y superar los beneficios obtenidos por la empresa.

El tribunal de Toole resaltó el gran beneficio obtenido por Richardson-Merrell con la venta del producto. En el caso Ford v. Grimshaw el jurado llegó a la cantidad inicial de 125 millones de dólares porque consideró que Ford se había ahorrado 100 millones y sumó 25 millones más como castigo.

El resultado contrario se alcanzó en Stiles v. Chloride, Inc ${ }^{52}$, en donde se negó la prueba de que el demandado había actuado en base a una «decisión económica» de mercado, como presupuesto para una condena de daños punitivos.

\section{c) El DEMANDADO NO REALIZÓ INVESTIGACIONES DE FORMA EFICIENTE, O NO HIZO ESFUERZO ALGUNO PARA REMEDIAR EL DAÑO}

La existencia de un producto defectuoso en el mercado puede ser debida a que no se detectó el defecto antes de sacar el producto al mercado, o que aunque éste fue detectado no se hizo nada para remediarlo. Una condena de daños punitivos puede deberse a que el demandado no ha cumplido con el estándar de cuidado aplicable a las pruebas anteriores o posteriores a la venta del producto para remediar los posibles defectos.

En Toole y Ford esta omisión del deber de cuidado era clara. Estos casos indican que el demandado actuó culpablemente durante el curso de sus operaciones. La culpa puede adoptar distintas formas; desde la prueba inadecuada de productos potencialmente peligrosos, intentos inadecuados para descubrir el remedio del defecto, no aportar un aviso o etiquetaje adecuado sobre el defecto del producto, o no poner en práctica remedios conocidos. La conducta del demandado puede tener lugar en el diseño, producción, información, o distribución del producto ${ }^{53}$.

52668 F. Supp 505 (WD NC 1987).

53 EI tribunal en MCIC v. Zenobia (86 Md App 456, 587 A2d 531 (1991)) declaró que la conducta de un fabricante que había sido notificado por un laboratorio (realizaba estu- 
Dos factores cruciales para determinar si el demandado incurrió en culpa son: el peligro potencial que posee el producto y la inherente dificultad financiera de realizar la prueba adecuada. Cuanto mayor es el riesgo potencial que supone un producto, más dinero se deberá invertir en pruebas y en control de calidad ${ }^{54}$.

\section{d) El COMPORTAMIENTO DEL DEMANDADO SUPERÓ LOS MODELOS DE CONDUCTA DE LA INDUSTRIA}

El caso Maxey v. Freightliner ${ }^{55}$ muestra la importancia de cumplir con los estándares de la industria. En este caso, el demandado fue absuelto de responsabilidad punitiva porque el sistema de gasolina diseñado en sus furgonetas se ajustaba al diseño utilizado por el resto de la industria nacional de furgonetas. Todo esto, a pesar de haberse probado que no realizó ningún test de choque en el sistema de gasolina, y que no llevó a cabo ningún estudio sobre accidentes de furgonetas.

De todas formas, cumplir con los estándares de la industria no evita que se demuestre que el fabricante actuó con «reckless disregard of plaintiff's rights», como ocurrió en el caso Gryc, en el que se declaró la responsabilidad del fabricante aunque había cumplido con los requisitos de la Flammable Fabrics Act ${ }^{56}$. Otro caso similar fue Dorsey $v$. Honda Motor Co., Ltd. ${ }^{57}$.

La relación entre los modelos de la industria y la condena de daños punitivos se ve clara en el caso Playtex ${ }^{58}$. Kelly O'Gilvie interpuso una demanda en su nombre y en el de su difunta esposa en contra de International Playtex, Inc. O'Gilvie alegó que el uso de los tampones fabricados por la empresa fueron la causa de la muerte de su esposa debido al «Toxic shock syndrome». El jurado consideró probado que el uso de

dios con animales sobre productos con asbesto) sobre el contenido de su producto, informándole de que éste contenía un componente peligroso (no colocó el aviso en el producto), era suficiente para justificar una condena de daños punitivos.

54 Ver Owen, «Punitive Damages in Product Liability Litigation», cit., p. 1.345.

55450 F. Supp 955 (ND Tex 1978).

56 Gryc v. Dayton-Hudson Corp. (Supreme Court of Minesota, 1980297 N.W.2d 727). El 8 de diciembre de 1969, Lee Ann Gryc, entonces de 4 años de edad, vestía un pijama fabricado con un material de algodón conocido como «flannelette». El pijama cumplía con los requisitos federales mínimos de inflamabilidad. Cuando Lee Ann se acercó al horno eléctrico su pijama se incendió y como consecuencia sufrió quemadoras graves en la parte superior de su cuerpo. El jurado declaró al demandado responsable y le condenó al pago de 750.000 dólares como daños compensatorios y un millón de dólares como daños punitivos. La apelación presentada por el demandado no tuvo éxito.

57655 F2d 650 (CA5, 1981).

58 Kelly M. O'Gilvie v. International Playtex Inc. (821 F.2d 1438 (10th Cir. 1987)). 
los tampones había sido la causa de la muerte de la señora O'Gilvie y que Playtex no había informado adecuadamente del riesgo fatal que el uso de sus productos podía suponer. Playtex alegó que su etiquetaje cumplía con las regulaciones de la Food and Drug Administration y que las instrucciones que se habían dado al jurado eran erróneas. Las instrucciones dadas al jurado fueron:

«En otras palabras, ustedes han sido instruidos para que en el caso de que consideren que el demandado cumple con todas las regulaciones y requisitos del Gobierno, los cuales son estándares mínimos, ese cumplimiento no sea una defensa si un fabricante prudente y razonable hubiese tomado mayores precauciones.»

Sin embargo, el tribunal no aceptó la alegación de Playtex. En su opinión, el hecho de cumplir con la regulación federal no era suficiente para que se le eximiera de responsabilidad si se demuestra que un fabricante cuidadoso no habría actuado de esa forma.

\section{e) El PRODUCTO NO OFRECÍA BENEFICIOS SUSTANCIALES QUE COMPENSASEN EL RIESGO}

El análisis del riesgo/beneficio se suele realizar, sobre todo, en casos de productos defectuosos en los que el producto es un fármaco. Son casos en que las drogas han producido una reacción conocida y adversa, pero relativamente rara. Debido a la necesidad de incentivar el desarrollo de nuevos fármacos, los fabricantes de drogas con un alto potencial de reacciones adversas han recibido protección por parte de los tribunales. Algunas jurisdicciones han adoptado el Restatement (Second) of Torts, secc. 402A (k), para proteger, en cierta medida, a los fabricantes de demandas por diseño defectuoso basadas en la strict liability. El Restatement reconoce que hay productos altamente beneficiosos, pero que conllevan un riesgo inherente e inevitable. Bajo la excepción de "unavoidably unsafe product», el fabricante sólo será considerado culpable si los avisos o la información sobre el riesgo son inadecuados o la droga fue fabricada inadecuadamente ${ }^{59}$.

Excepción hecha de los casos que tratan con la industria de farmacia, no ha habido discusión sobre el análisis del riesgo/beneficio. Si el demandado puede demostrar que cuidadosamente valoró el daño frente al beneficio para la sociedad, que advirtió a los consumidores del peligro potencial, y que además fue incapaz de remediar dicho defecto en el producto, entonces no será declarado responsable.

59 Ver: Stone v. Smith, klein \& French laboratories, 447 So2d 1301 (Ala 1984); Kearl v. Lederle laboratories, 172 Cal App 3d 287, 218 Cal Rptr 453 (1985); Feldman v. Lederele Laboratories, $97 \mathrm{Nj}$ 429, 479 A2d 374 (1984). 


\section{Reformas}

En las últimas décadas, las manifestaciones en contra de la figura de los daños punitivos han sido abundantes. Como hemos podido ver, en el amplio espectro de la doctrina y jurisprudencia norteamericana se pueden encontrar autores que defienden la figura ${ }^{60}$, autores que piden su reforma (de forma sustancial o parcial) ${ }^{61}$, y autores que abogan por su abolición ${ }^{62}$.

60 Algunos artículos que defienden el status quo actual: BeDELL, «Punitive damages in arbitration», en John Marshall Law Review, vol. 21, 1987; BELLI, «Punitive damages: Their history, their use and their worth in present-day society», en UMKC Law Review, vol. 49, 1980; CORBOY, «Are punitive damages getting out of control? the existing controls are effective», en A.B.A. J., vol. 70, (Dec. 1984), pp. 16 y ss.; COURTEY \& CAVICO, «Punitive damages: When are they justificable?», en Trial, vol. 18, 1982, pp. 52 y ss.; DEMAREST \& JoNES, «Exemplary damages as an instrument of social policy: Is tort reform in the public interest?», en St. Mary Law Journal, vol. 18, 1987, pp. 797 y ss.; SchwarTz, «Deterrence and punishment in the common law of punitive damages: A comment», en South California Law Review, vol. 56, 1982, pp. 133 y ss.; ChAPMAn, M.A., «Punitive Damages as a Solution to Drunken Drivers», en Missouri Law Review, vol. 52, 1987, pp. 949 y ss.; DanIELS, S. Y MARTin, J., «Jury Verdicts and the "crisis" in Civil Justice: Some Findings from an Empirical Study», en Justice System Journal, vol. 11 de 1987, p. 321; LEWIS WeLLS M., «Comments on why punitive damages don't deter corporate misconduct effectively», en Alabama Law Review, vol. 40, 1989, pp. 1.073 y ss.; KoENING T. Y RuSTAD M., «The quiet revolution revisited: An empirical study of the impact of state tort reform of punitive damages in product liability», en The Justice System Journal, vol. 16, 1993, pp. 21-44.

61 Algunos artículos que defienden la reforma: BARRETT \& MERRIMAN, «Legislative remedies for punitive damages», en Federation of Ins. Counsel Quarterly, vol. 28, 1978, pp. 339 y ss.; Bell \& PeARCE, «Punitive damages and the tort system», en U. Richmon Law Review, vol. 22, 1987, pp. 1 y ss.; COOTER, «Economic analysis of punitive damages», en South California Law Review, vol. 56, 1982, pp. 79 y ss.; ElLIS, «Fairness and efficiency in the law of punitive damages», en South California Law Review, vol. 56, 1982, pp. 1 y ss.; FIEWEGER, J., «The need for reform of punitive damages in mass tort litigation: Juzwin v. Amtorg Trading Corp», en De Paul Law Review, vol. 39, 1990, pp. 775 y ss.; Johnston, «Punitive liability: A new paradigm of efficiency in tort law», en Columbia Law Review, vol. 87, 1987, pp. 1.385 y ss.; LAUNIE, «The incidence and burden of punitive damages», en Insurance Consel Journal, vol. 53, 1986, pp. 46 y ss.; LEVIT, «Punitive damages: Yesterday, today and tomorrow», en Insurance Law Journal, 1980, pp. 257 y ss.; LoYD NEAL, S.: «Punitive damages: suggested reform for an insurance problem», en St. Mary's Law Journal, vol. 18 de 1987, pp. 1.019 y ss.; Mallor \& Roberts, «Punitive damages: Toward a principled approach», en Hasting Law Journal, vol. 31, 1980, pp. 639 y ss.; MARTIN, «The relation of exemplary damages to compensatory damages», en Texas Law Review, vol. 22, 1944, pp. 235 y ss.; MCCoRMicK, «Some phases of the doctrine of exemplary damages», en North Carolina Law Review, vol. 8, 1930, pp. 129 y ss.; MORRIS, «Punitive damages in tort cases», en Harvard Law Review, vol. 44, 1931, pp. 1.173 y ss.; OwEN, «Civil punishment and the public good», en South California Law Review, vol. 56, 1982, pp. 103 y ss.; PHILIPS, «The punitive damages class action: A solution to the problem of multiple punishment», en University of Illinois Law Review, 1984, pp. 153 y ss.; PRIEST, «Punitive damages and enterpri- 


\section{Abolición de los daños punitivos}

Los que abogan por la abolición de esta figura hacen uso de los argumentos ya clásicos en su contra. Estos autores y tribunales sostienen que los daños punitivos no tienen cabida en un Derecho civil moderno, que pertenecen al pasado, que no cumplen ninguna de las funciones que tiene encomendadas, y que están llevando a la ruina a la economía norteamericana.

La abolición de la figura puede ser total o parcial; es decir, puede afectar sólo a algunas áreas del Derecho de daños (por ejemplo, a la medical malpractice o a la product liability), o que se prohíba la imposición de daños punitivos para todos los supuestos del Derecho de responsabilidad extracontractual.

La organización que claramente se ha manifestado a favor de la abolición es el Defense Research Institute (DRI). En 1969 dedicó una monografía de tres artículos al tema de los daños punitivos. Su conclusión fue:

«La doctrina de los daños punitivos ha sobrevivido al propósito para el cual fue creada. Es un anacronismo que debería ser retirado del Derecho modemo de tort tan rápido como sea posible. Aunque un repaso del desarrollo histórico de la doctrina provea de una explicación para su nacimiento, no se entiende que continúe existiendo (...). Pero las medidas para mejorar y modernizar el Derecho deberían incluir la abolición judicial o legislativa de la injusta doctrina de los daños punitivos. Un análisis de la verdadera naturaleza compensatoria del Derecho de daños lleva a la conclusión de que las cuatro jurisdicciones minoritarias que

se liability», South California Law Review, vol. 56, 1982, pp. 123 y ss.; RILEY, «Punitive damages: The doctrine of just enrichment», en Drake Law Review, vol. 27, 1977-78, pp. 195 y ss.; SELTZER, «Punitive Damages in Mass Tort Litigation: Adressing the Problems of Fairness, Efficiency and control», en Fordham Law Review, vol. 52, 1983, pp. 37-92.; WHEELER, «The constitutional Case for reforming punitive damages procedure», en Va. Law Review, vol. 69, 1983, pp. 269 y ss.; WoODBURY, «Limiting discovery of a defendant's wealth when punitive damages are alleged», en Duquesne Law Review, vol. 23, 1985, pp. 349 y ss.

62 Algunos artículos que defienden la abolición son: CARSEY, «The case against punitive damages: an annotated argumentative outline»," en Forum, vol. 11, 1975, pp. 57 y ss.; DuBoIs, «Punitive damages: Bonanza or disaster», en Litigation, vol. 3, 1976, pp. 35 y ss.; GHIARDI, «The case against punitive damages», en Forum, vol. 8, 1972, pp. 411 y ss.; GHIARDI, «Should punitive damages be abolished?»- «A Statement for the affirmative», en ABA sec. Ins. Negl. \& Comp. L. proc., 1965, pp. 282 y ss.

LONG, «Punitive damages: An Unsettled doctrine», en Drake Law Review, vol. 25, 1976 , pp. 870 y ss.; SALES y CODE, «Punitive damages: a relic that has outlived its origins», en Vanderbilt Law Review, vol. 37, 1984, pp. 117 y ss.; ElLIOT, D., «Why punitive damages don't deter corporate misconduct effectively», en Alabama Law Review, vol. 40, 1989 , pp. 1.053 y ss. 
han rechazado los daños punitivos representan lo que debería ser el movimiento futuro del Derecho» ${ }^{63}$.

Tanto los autores como las asociaciones que apoyan la abolición de los daños punititvos están de acuerdo en que, por el momento, no es posible llevarla a la práctica. Todos ellos, en mayor o menor medida, han planteado alternativas a la abolición total, como por ejemplo límites en la cuantía de la condena, definición precisa del modelo de conducta que da lugar a la responsabilidad punitiva, etc.

Ningún parlamento estatal ha incluido dentro de sus propuestas de reforma la abolición total de los daños punitivos. Sin embargo, una minoría de jurisdicciones ha optado por prohibir la condena de daños punitivos para supuestos concretos. Liderando este esfuerzo está New Hampshire, que prohíbe su imposición, a menos que estén recogidos de forma expresa en una ley ${ }^{64}$.

Otras jurisdicciones han elegido prohibir los daños punitivos para determinados demandados, o bien cuando no se cumplen algunos requisitos adicionales ${ }^{65}$.

\section{Instituir límites en el quantum de la condena}

La gran mayoría de la doctrina norteamericana ha apostado por una reforma parcial de los daños punitivos. Consideran que la figura debe permanecer (ya que sus fines son beneficiosos para la sociedad), pero que se deben corregir algunos de sus defectos.

Una de las mayores críticas que han recibido estos daños es que dan lugar a condenas económicamente desproporcionadas en su quantum. La solución que la doctrina ve a este problema es la de limitar la

63 Ver Defense Research Institute Monograph, The case against punitive damages, 4-14 (1969), DUFFY, Punitive damages: A doctrine which should be abolished).

${ }^{64}$ New Hampshire Review Statute Annatation, 507.16 (1987). No podemos considerar que la medida adoptada por este Estado sea representativa, ya que en New Hampshire la condena punitiva tenía una naturaleza especial que la diferenciaba de los otros Estados. Aquí, su naturaleza era compensatoria, y no de castigo o disuasoria.

65 Por ejemplo, Illinois los ha prohibido en los casos de medical malpractice, y también exime a los funcionarios públicos de responsabilidad punitiva (Illinois Annotation Statute, chapter 110, par 2-1.115 (1987)). En Texas, Oregon y Ohio se han abolido contra los fabricantes de fármacos, siempre que hayan previamente cumplido los reglamentos de la Food and Drug Administration (Ohio Rev. Code Annotations 2307. 80(c) (1988), Oregon Rev. Statutes 30.927 (1988), Texas Civil Practice \& Rem Code Annotations 81.003 (1987)). Oregon los prohíbe contra aquellos que practican la medicina, siempre que su conducta profesional estuviera dentro de los modelos habituales de la práctica de la medicina (Oregon Review Statute 18.550 (1988)). 
cuantía, bien mediante el establecimiento de un techo máximo, o bien mediante la creación de una regla de proporcionalidad con los daños compensatorios.

El American College Of Trial Lawyers, en el informe de 1989, tomó en consideración varias técnicas en un intento de controlar el quantum de las condenas. Algunos miembros del comité estaban a favor de utilizar un límite máximo, mientras que otros se oponían a la adopción de esta medida. El comité, finalmente, recomendó la creación de una ley que limitase las condenas de daños punitivos al doble de la condena compensatoria o a 250.000 dólares (la que fuese mayor de las dos). El jurado no debía ser inforrnado de estos límites. El techo monetario debía ser aplicado por el tribunal cuando fuese necesario, pero siempre después de alcanzado el veredicto por el jurado ${ }^{66}$.

La Alliance Of American Insurers ${ }^{67}$ plantea que se limite la cantidad:

a) al $25 \%$ de los daños compensatorios, o bien;

b) a 5.000 dólares.

Los Estados que han modificado sus leyes para restringir el quantum de la condena con un límite máximo son: Colorado, Connecticut, Georgia, Montana, Nevada, Oklahoma, Virginia, Florida, Kansas, Ohio, Alabama y Texas ${ }^{68}$.

La medida limitativa de la cuantía de las condenas ha provocado las críticas de un sector de la doctrina ${ }^{69}$. La crítica se dirige a lo que ellos consideran como «naturaleza arbitraria de esta solución simplista ${ }^{70}$. Y también, porque se priva al jurado de su derecho a hacer que la condena esté de acuerdo con el mal causado y con la condición finan-

66 Ver el American College of Trial Lawyers, Report of Punitive Damages of the Committee of Special Problems in the Administration of Justice, 1989, p.12: «El quantum de los daños punitivos debería estar limitado por una fórmula flexible basada en la cantidad de daños compensatorios».

67 Alliance of American Insurers, Current Issues: Civil Justice, 2. ${ }^{\mathrm{a}}$ ed., 1986.

68 Por ejemplo, en Texas, excepto en los casos de malicia o intención, la condena no puede exceder de la cantidad que resulte de multiplicar por cuatro el quantum de los daños actuales o de 200.000 dólares (Texas de los daños punitivos se limita a 250.000 dólares (Georgia Code Annotations 51-12-5.1 (e), (f), (g) (1987)). En Kansas se limita la cantidad a la menor de la renta bruta anual máxima obtenida por el demandado durante los tres años anteriores al daño, o a 5 millones de dólares (Kansas Statute Annotations 60-3701 (1987)).

69 Ver, por ejemplo Demarest, S.M., Jones, D.E., Exemplary Damages as an instrument of Social Policy..., cit., p. 797.

70 Ver, por ejemplo SELtzer, «Punitive damages in Mass Tort litigation: Addressing the problems of fairness, efficiency and control», en Fordham Law Review, vol. 52, 1983, pp. 37 y ss. 
ciera del demandado particular. Añaden que se disminuye el valor disuasorio de los daños punitivos.

De todas las reformas que se han practicado en este campo, las que imponen límites máximos sobre la cuantía son las que pueden verse sometidas a recursos de inconstitucionalidad con más facilidad. De hecho los tribunales que han tratado este tema han declarado, de forma casi mayoritaria, que los límites son inconstitucionales.

\section{Entrega del quantum económico de la condena total o parcialmente a un fondo estatal}

Una de las críticas tradicionales hacia los daños punitivos es que en la práctica son un regalo que se da al demandante. La víctima ya ha sido indemnizada con los daños compensatorios, por lo que toda cantidad que exceda de éstos supondrá un regalo o un premio para aquél que la recibe. A este argumento se ha respondido con la propuesta de reforma que supone entregar la cantidad económica, concedida por el tribunal en concepto de daños punitivos, a una persona (física o jurídica) distinta de la víctima ${ }^{71}$.

Los fines de castigo y de disuasión son los únicos que tienen algún mérito en la actualidad. Por lo que este modelo de reforma ofrece la oportunidad de probar la sinceridad de aquellos que utilizan la función disuasoria y de castigo como argumento para retener los daños punitivos, y determinará si es que se oponen a su abolición por otras ventajas que les producen los daños punitivos (es decir, los beneficios que aportan a los abogados de los demandantes).

El American College of Trial Lawyers se ha opuesto a esta reforma. Consideran que tanto la víctima como su abogado perderían el incentivo para entablar este tipo de demandas ${ }^{72}$.

Las jurisdicciones que han limitado la cantidad que un demandante puede recibir otorgando parte de la condena a un fondo estatal o enti-

71 Ver, por ejemplo: Sales, J.B. y Cole, K.B.Jr., «Punitive Damages a relic that has outlived its origins», en Vandervilt Law Review, vol. 37, 1984, pp. 1.117 y ss., en el que se da como alternativa a la abolición el que la condena vaya al Tesoro del Estado igual que las otros multas o penas criminales.

72 En el Report on Punitive damages of the Committee of Special Problems in the Administration of Justice... cit., p. 20 (1989) se dice:

«En resumen, el Comité ha concluido que el common law durante largo tiempo ha permitido que el demandante victorioso retenga la indemnización por daños punitivos, y es justificable en base a que fue el demandante el que pasó por todos los problemas de entablar y continuar con la demanda en primer lugar. El Comité no ve ninguna justificación real para cambiar la situación actual.» 
dad públicas son: Florida, Colorado, Georgia, Iowa, Missouri Illinois, Utah, Oregon y New York ${ }^{73}$.

En nuestra opinión, esta medida plantea otro problema: la posición en que se encuentran todos aquellos que realizan un convenio extrajudicial frente a los que alcanzan la indemnización por la vía judicial. Los primeros no se verán expuestos a la entrega de ninguna cantidad a un fondo estatal. La cantidad convenida entre las partes será entregada en su totalidad a la víctima. Además, en la determinación de esa cantidad se habrá tenido en cuenta la posible condena de daños punitivos si el caso llegase a los tribunales. Este problema se ha intentando solventar mediante la propuesta de que los convenios extrajudiciales se pongan en conocimiento del tribunal, una vez llegado al acuerdo. Las dificultades prácticas de esta propuesta han frenado, en nuestra opinión, su apoyo legislativo.

\section{Bifurcación del proceso o abolición del jurado}

Otra crítica tradicional hacia los daños punitivos es que, en la imposición de las condenas, los jurados tienen un poder casi ilimitado que debería ser controlado, abolido o restringido. Se ha dicho que el jurado no tiene los conocimientos necesarios para poder juzgar sobre un caso de daños punitivos y que se deja llevar muy frecuentemente «por la pasión».

Algunos autores ${ }^{74}$ han propuesto una redistribución del poder judicial. De tal forma que los que decidan si hay lugar a daños punitivos, y cuál es el quantum de la condena sean los jueces, una vez que el jurado ha decidido sobre los daños compensatorios. Los jueces son quienes tienen experiencia y familiaridad con los conceptos legales, por lo que están mejor capacitados que los jurados para distinguir aquellos comportamientos que merecen un castigo de los que no.

Otros autores opinan que no es necesario suprimir totalmente la figura del jurado, ya que este órgano podría decidir sobre la existencia o

73 Por ejemplo, la legislación de Florida limita la cantidad a recibir por el demandante al $65 \%$ de la condena de daños punitivos. Si la demanda está basada en una acción por personal injury o wrongful death, el 35\% sobrante se entrega al Public Medical Assistance Trust Fund. En las otras acciones el remanente se da al General Revenue Fund (Florida Statute 768.73(2) (1992)). New York también ha adoptado una legislación que otorga el $20 \%$ de la condena al Estado (1992 New York Laws, Chapter 55, 393 (effective april 10, 1993)).

74 Por ejemplo SAles, J.B. y Cole, Jr., Punitive Damages a Relic that has Outlived its Origins... cit., pp. 1.117 y ss. 
no de responsabilidad punitiva, pero sin determinar el quantum de la condena; función, esta última, que pasaría a estar en manos del juez ${ }^{75}$.

En los estados de Georgia, Montana, Nevada y Kansas se exige la bifurcación del proceso para todos los casos de daños punitivos ${ }^{76}$. En el primer juicio se examina la responsabilidad, y en el segundo el quantum de la condena punitiva. En estas jurisdicciones se utiliza el mismo juzgador en los dos procesos.

\section{Equiparación con el nivel de prueba del Derecho penal}

Las alegaciones de las partes en el proceso civil norteamericano, en principio, requieren ser probadas por una «preponderancia de evidencia». El hecho de que los daños punitivos tengan como funciones el castigo y la disuasión (las cuales son funciones clásicas del Derecho penal) determinó que algunos autores se preguntasen por qué no elevar el requisito de la prueba a los niveles del Derecho penal o a un nivel intermedio (el Derecho penal norteamericano exige normalmente que una vez realizada la prueba no exista «ninguna duda razonable»). Otros, más conservadores, se conforman con que los hechos deban ser probados bajo una «evidencia clara y convincente».

La importancia de esta desigual apreciación en la prueba va más allá de la mera diferencia terminológica, ya que si aplicamos el criterio más restrictivo de prueba ( «under no reasonable doubt») veríamos reducido el número de las condenas de daños punitivos como consecuencia de falta de prueba.

Alaska, Florida, Indiana, Montana, South Carolina, Alabama, Oregon, Kentucky y Ohio (para los casos de product liability) han adoptado el modelo de «clear and convincing evidence for punitive damages» ${ }^{77}$.

La ley de Montana establece que:

«(...) prueba clara y convincente significa una evidencia en la cual no hay duda seria o sustancial sobre la corrección de las conclusiones alcanzadas con la prueba. Esto es más que una preponderancia de prueba, pero menos que "beyond a reasonable doubt" $\gg^{78}$.

\footnotetext{
75 EI profesor Owen, Civil Punishment and the Public Good..., cit., pp. 103 y ss., es de esta opinión.

76 Georgia Code Annotations 51-12-5.1; Kansas State Annotations 60-3201; Montana Code Annotations 27-1-221; Nevada Review Statute 42.005(3).

77 Alaska Statute. 09.17.020 (1987); Florida Statute Annotations 768.73(1)(b) (1988); Indiana Code Annotations 34-4-34-2 (1988); Oregon Review Statute 41.315 (1987); Alabama Code 6-11-20(b)(4) (1987); Montana Code Annotations 27-1-221(5) (1987).

78 Montana Code Annotations 27-1-221(5) (1987).
} 


\section{Prueba de la riqueza del demandado}

En un proceso en el que se reclaman daños punitivos, la admisión de pruebas encaminadas a mostrar la riqueza o el capital del demandado constituye una de las partes más controvertidas del proceso. Los daños punitivos (para alcanzar una disuasión y castigo suficientes) deben tener en cuenta el capital que posee el agente ilícito. Es evidente que una misma condena económica no servirá igual como castigo para un demandado, persona física o pequeña empresa, que para una de las grandes corporaciones. La cantidad necesaria para castigar y disuadir a una multinacional debe ser, en principio, muy superior a la cantidad necesaria para disuadir a una pequeña empresa familiar. Como consecuencia de esto se ha admitido que en el proceso se aporten pruebas encaminadas a descubrir el beneficio neto de la empresa, su capital, etc.

Esta práctica dio lugar a que algunos autores considerasen que la prueba era muy perjudicial para el demandado. En último término, hacía que el jurado prejuzgara al agente y emitiera su veredicto, principalmente, en base a su riqueza y no a su comportamiento.

Algunas jurisdicciones introdujeron límites a la admisión de prueba referente al capital del demandado. Por ejemplo, Oregon y Iowa no admiten evidencia de la condición financiera del demandado hasta que la parte que pide los daños punitivos los pruebe totalmente ${ }^{79}$. Missouri requiere un juicio bifurcado; en el primero se examina la responsabilidad del demandado, y la admisión de evidencia sobre el capital del agente sólo es posible en el segundo juicio. Es decir, una vez determinada su responsabilidad ${ }^{80}$.

\section{Delimitación precisa de los criterios de imposición} de la responsabilidad por daños punitivos. Conducta del demandado

El profesor Owen ${ }^{81}$ considera que las dificultades más serias de la doctrina de los daños punitivos se encuentran en la incertidumbre que rodea a su aplicación, y la causa principal de incertidumbre es la imprecisión que existe en la definición de las reglas de responsabilidad. La falta de precisión se ve exagerada por el amplio poder discrecional que ostenta el jurado. Este autor considera que la imposición de un castigo por cometer una ofensa definida de forma vaga da lugar a una indemnización injusta e ineficiente.

\footnotetext{
79 Oregon Review Statute 41.315(2) (1988).

${ }^{80}$ Missouri Annotations Statute 510.263(3) (1987).

81 Owen, Civil Punishment and the Public Good... cit., p. 114.
} 
Esta falta evidente de una definición precisa y uniforme afecta de forma especial a la descripción de la conducta del agente necesaria para dar lugar a la responsabilidad punitiva. Una descripción exacta de la conducta necesaria para la condena de daños punitivos mejoraría el ambiente que rodea a toda la teoría. El juzgador tendría un mejor entendimiento de la conducta que debe juzgar. Una definición más concreta limitaría el ámbito de investigación del juzgador. Además, podría garantizar que los daños punitivos fuesen más equitativos y en conformidad con sus propósitos.

Las jurisdicciones de Alabama, Kentucky, Montana, California, New Jersey y Texas han intentado aclarar el tipo de conducta necesario, mediante un intento de establecer un lenguaje legal específico.

A pesar de estos esfuerzos por llegar a una definición clara acerca de cuál es la conducta que da lugar a estos daños, se echa de menos una legislación a nivel nacional que dé uniformidad a todo el sistema.

\section{Recapitulación}

En cualquier país europeo, la abolición de una figura similar a la de daños punitivos no sería conflictiva. Sin embargo, la situación en los Estados Unidos es bien distinta.

En mi opinión los daños punitivos deberían ser eliminados. En primer lugar, los daños punitivos son una pena, y la imposición de penas siempre va acompañada de medidas de garantía. El Derecho civil no es el lugar apropiado para castigar al culpable. Esa función la realiza mejor el Derecho penal, en el que las garantías son mayores que en el Derecho civil. En segundo lugar, las conductas que dan lugar a una condena de daños punitivos no sólo no están bien definidas, sino que no existe uniformidad entre las normas estatales. En tercer lugar, no tienen función compensatoria, ya que en la actualidad la categoría de pain and suffering comprende muchos (si no todos) de los daños que en el pasado no eran indemnizados. Tampoco la función disuasoria justifica la existencia de estos daños; aunque aceptemos que esta función existe, no se debe dejar en manos del jurado. En cuarto lugar, respecto a la alegación común de que los daños punitivos son la única herramienta efectiva que tiene la sociedad para ejercer control sobre el ansia de beneficios de los fabricantes, se puede decir que una indemnización compensatoria adecuada ya lo logra. Pero si no es así, tal vez la solución debería venir de una mayor regulación administrativa. Si el fabricante posee la habilidad de estimar y de incluir sus costes por daños compensatorios futuros como gastos de empresa, y por lo tanto de eliminar sus 
efectos disuasorios, se debe corregir administrativamente. En quinto lugar, en los casos de responsabilidad por productos defectuosos y daños a más de una persona, la condena punitiva debe agotar los fondos de la empresa y malograr las expectativas de indemnización para otras víctimas, aún en el caso de que se reclamen sólo daños compensatorios. Existen leyes de protección al consumidor que realizan la función de los daños punitivos.

Ninguna de las reformas estatales ha tenido mucho éxito. Los casos de responsabilidad por productos defectuosos, en muchas ocasiones, afectan a más de un Estado, por lo que ésta es una de las áreas más necesitadas de regulación federal. 
Anexo

En diciembre de 1994 la National Conference of Commissioners on Uniform State Laws propuso un modelo de ley de daños punitivos uniforme para todos los Estados de la Unión:

\section{MODEL PUNITIVE DAMAGES ACT}

\section{Section 1. Definitions}

In this (Act):

(1) «Compensatory damages» means those damages, including nominal damages, awarded to compensate for a legally recognized injury, but does not include an award the sole purpose of which is to punish, deter, or make an example of the actor.

(2) «Intent» means that the actor desires to cause the consequences of an act or realizes that the consequences will or are substantially certain to result from the act.

(3) «Person» means an individual, corporation, limited liability company, business trust, estate, partnership, association, joint venture, govemment, govemmental subdivision, agency, or instrumentality, or any other legal or commercial entity.

(4) «Punitive damages» means those damages awarded solely for the purpose of punishing, deterring, or making an example of the actor.

(5) «Wanton» means that the actor realizes there is a strong probability that seriourly harmful consequences will result from an act and proceeds to act despite the realization, but does not include conduct where the actor merely, from facts known to the actor, should realizes that there is a strong probability that harm may result.

\section{Section 2. Punitive damages in civil actions}

Except as provided in this (Act), a claimant in a civil action commenced in this state may not seek or recover punitive damages.

\section{Section 3. Petitions for punitive damages}

A petition filed in an action which punitive damages are sought must contain a short and plain statement showing that the claimant is entitled to an award of punitive damages and a demand for judgment for such a damages, but may not contain a dollar amount or monetary figure.

\section{Section 4. Liability for punitive damages}

(a) To justify an award of punitive damages, the calimant must persuade the trier of fact by clear and convincing evidence that the defendant: 
(1) intended to harm or wantonly harmed the person whose injury is the basis for the claim;

(2) acted for malicious or outrageous reasons; and

(3) deserves to be punished, deterreed, or made an example of because of the defendant's action and reasons.

(b) An award of punititve damages may not be based on mere negligence or extreme carelessness.

(c) Even where a claimant adduces evidence from which the trier of fact could make the findings in subsection (a), it remains within the discretion of the trier of fact where to ward punitive damages.

\section{Section 5. Amount of award}

If the trier of fact finds that an award of punitive damages is warranted, it may award an amount based upon clear and convincing evidence it finds to be fair and reasonable. In making such an award, the trier of fact may take into consideration one or more of the following factors:

(1) the nature of defendant's conduct;

(2) the impact of defendant's conduct on the claimant;

(3) the relationship between the claimant and the defendant;

(4) the likelihood that the defendant will repeat the conduct if a punitive award is not made;

(5) the defendat's financial condition; and

(6) any other circumstances shown by the evidence, including any circumstances of mitigation, that bear on the question of the amount of any punitive award.

\section{Section 6. Respondeat superior}

If the trier of fact finds that the conduct of any employee or agent warrants an award of punitive damages, it may consider whether and award also should be made against the employer or principal of the individual. However, the employer or principal may be liable for punitive damages only if the employer or principal:

(1) authorized, participated in, consented to, acquiesced in, or ratified the action of the employee or agent with knowledge of its wrongful character; or

(2) was reckless in selecting or retaining the employee or agent because it was known that such an individual would be likely to engage in the type of conduct for which the trier of fact found the individual liable.

\section{Section 7. Punitive award limit}

(a) The amount recoverable for punitive damages for any one act or course of conduct by a defendant is limited to twice the amount of compensatory damages awarded against the defendant for the same act or course of conduct or $(250.000$ $\$$ ), whichever is greater.

(b) If more than one judgment containing an award of punitive damages is entered against a defendant for the same act or course of conduct, the defendant 
may petition a court of competent jurisdiction in this state for a declaratory judgment that the defendant is not liable for more than the limit set out in subsection (a) or for a hearing to determine how much, if any, amount of punitive damages previously paid by the defendant as a resukt of the same act or course conduct should be credited against any other judgment sought to be enforced against the defendant in this state.

\section{Section 8. Consolidation of trials}

(a) If more than one action containing a claim for punitíve damages is fled in this state against a defendant for the same act or course of conduct, a court (pursuant to rules of civil procedure) may order:

(1) all the actions consolidated for the trial; or

(2) a joint hearing or trial of any or an the maffers in issue in the actions.

(b) The court may make such orders concernings any proceeding under subsection (a) as may tend to avoid prejudice or unnecessary costs or delays.

\section{(alternative A)}

\section{Section 9. Separate trials}

In a trial involving a claim for punitive damages, the court (pursuant to rules of civil procedure) may order a separate trial of any claim or issue in furtherance of convenience ot to avoid prejudice, always preserving inviolate the right of trial by jury.

\section{(alternative B) Section 9. Separate trials}

(a) In a trial where a claim for punitive damages is made and evidence of wealth or financial condition is not relevant to any liability issue, the court, upon motion by the party against whom the claim is made, shall bifurcate the trial. During the first phase of the trial, the issues of liability for compensatory and punitive damages shall be determined and evidence of wealth or financial condition shall be admissible. Separate findings should be made regarding any liability for compensatory damages and for punitive damages. If it is determined in the first phase that punitive damages are to be awarded, evidence of the appropiate amount, including that of wealth of financial condition where relevant, shall be admissible in the seconf phase of the trial.

(b) If a claim for punitive damages and a motion for a bifurcated trial are made, the claimant may show that wealth or financial condition is relevant to the issue of liability for punitive damages. If the court finds to be the case, the court shall bifurcate the trial by limiting the first phase to a determination of whether the defendant is liable for compensatory damages and the amount thereof. If a finding of liability is made in first phase of the trial, the second phase shall determine liability for punitive damages and the amount thereof. During the second phase of the trial, evidence of wealth or financial condition where relevant, shall be admissible. In a jury trial pursuant to this subsection, the court 
shall inform the jury during the first phase of the trial that a claim for punitive damages has been made, but that this issue may be addressed in a second phase of the trial affer the issue of liability for compensatory damages has been decided.

(c) In addition to the situations described in subsections (a) and (b), in any other trial involving a claim for punitive damages a court upon good cause shown may order a separate trial of any claim or issue in furtherance of convenience or to avoid prejudice, always preserving inviolate the right of trial by jury.

\section{Section 10. Short title}

This (Act) may be cited as the Model Punitive Damages Act.

\section{Section 11. Severability clause}

If any provision of this (Act) or its application to any person or circunstance is held invalid, the invalidity does not affect other provisions os applications of the (Act) which can be given effect without the invalid provision or application, and to this end the provision of this (Act) are severable.

\section{Section 12. Effective date}

This (Act) takes effect on

\section{Section 13. Repeal}

The following acts and parts are repealed: 
CRONICA 



\title{
SIMPOSIUM SOBRE «EVANGELIUM VITAE Y DERECHO» Roma, 23-25 de mayo de 1995
}

\author{
Pedro M. ${ }^{a}$ Garín Urionabarrenechea
}

El 25 de marzo de 1995 el Papa Juan Pablo II publicaba la Carta Encíclica «Evangelium Vitae». Conmemorando el primer aniversario de su nacimiento, los días 23-25 de mayo se celebró un Simposio en la Ciudad del Vaticano, organizado conjuntamente por el Pontificio Consejo para la Interpretación de los Textos Legislativos, el Pontificio Consejo «Pro Familia» y por la Pontificia Academia «Pro Vita», bajo el epígrafe «Evangelium vitae e Diritto».

Si damos por cierta la información publicada por el L'Osservatore Romano, el Simposio congregó a cuatrocientos docentes del mundo del derecho, de la filosofía y de la ética, procedentes de cerca 150 Universidades e instituciones culturales de 26 países de diversos continentes del mundo ${ }^{1}$.

1. La apertura del Simposio corrió a cargo del Cardenal Alfonso López Trujillo, a la sazón Presidente del Pontificio Consejo para la Familia.

El Cardenal, intentando plasmar el hondo calado del Simposio, en el que se ven involucrados tres dicasterios de la Santa Sede, ofrece un elenco de datos, que caracterizan «con una tristísima peculiaridad, la expansiva cultura de la muerte». Por primera vez en la historia del mundo el delito es considerado como derecho: cincuenta millones de abortos «legales», consumados en un año; eliminación sistemática de niños, aun nacidos, sacrificados en obsequio a las leyes demográficas; intervenciones directas de los Jefes de Estado por bloquear iniciativas parlamentarias que tienden a restringir en ciertas condiciones la legalidad del aborto; férrea voluntad de introducir o alargar la legalización del aborto en legis-

1 Las fuentes de esta memoria son los textos entregados a los congresistas, las crónicas del L'Observatore Romano y las notas del autor; OR., 29 de mayo 1996, 6. 
laciones que hasta hoy no lo admitían; enconamiento penal para quienes pacíficamente se manifiestan contra el aborto; legalización de la eutanasia.

Se subraya la degradación en la que caen «todas aquellas democracias que vacían al hombre de sus valores éticos fundamentales y dan vida a sociedades enfermas "en el corazón" y "en la conciencia", hasta el punto de favorecer la extensión de la cultura de la muerte como fenómeno social».

El simposio - manifiesta el Sr. Cardenal- busca como objetivo reflexionar acerca de la incidencia que los principios morales sancionados en la Encíclica tienen en el mundo de la justicia, en el concepto mismo de la justicia, en el mundo académico universitario y legislativo, en pro de la tutela de la verdad objetiva sobre la persona humana y sus derechos fundamentales, el primero de ellos, el derecho a la vida.

Mons. Julián Herranz, Presidente del Pont. Consejo para la Interpretación de los Textos Legislativos, por su parte, es quien delinea los cauces de la reflexión con su título introductorio: La estructura moral de la libertad.

A nuestro entender, su exposición abarca dos apartados intrínsecamente unidos entre sí:

a) La constatación, tanto desde el punto de vista filosófico como jurídico, de negar la existencia de una verdad ontológica acerca del hombre, fruto del empirismo jurídico, base de algunas legislaciones, que está llevando a un lento, pero progresivo empobrecimiento de todo el sistema jurídico.

Este dato histórico, según Mons. Herranz, se prueba confrontando las legislaciones y la tutela de los derechos fundamentales de la persona, el más importante, sin duda alguna, el derecho a la inviolabilidad de la vida humana. «Frente a las proclamaciones universales (de los derechos humanos), y, por lo tanto, válidas para la totalidad de los individuos y de los Estados, debemos registrar en el mundo posiciones ideológicas y legislaciones civiles claramente contrarias. El graso equívoco está en la corrupción del concepto de legalidad que a veces se crea, cediendo a la tentación de entender el hombre, no en su efectiva realidad, en su esencia natural, sino en la forma que mejor se adecua a ciertas formaciones ideológicas, construidas por desgracia sobre mayorías numéricas o bajo las presiones de los "lobbies". En esta dinámica "todo es pactable, todo es negociable" (EV. n. 20), incluso los derechos, cuya atribución le viene de la voluntad de los otros, negando la existencia de unos derechos inherentes a su misma 
naturaleza. Se traiciona así la verdad ontológica sobre el hombre, sobre su existencia. Por ello, el Santo Padre insiste siempre en afirmar que en el corazón del hombre está inscrita una ley moral, que en cuanto ley natural inscrita en el corazón del hombre, es punto de referencia normativa de la misma ley civil (EV. n. 70). Esta ley constituye el fundamento de la Declaración universal de los derechos del hombre. Mas, he aquí, la paradoja: en el siglo, en el que se ha escrito una tal Declaración que tutela los derechos objetivos y no volubles precisamente porque son universales, por lo tanto, no ligados al vaivén de la opinión de las gentes, sucede que algunas legislaciones positivas terminan por negarlos, una tras otra». ¿Cómo superar esta realidad destructiva de la humanidad?

b) La defensa de la estructura moral de la libertad humana frente a las dos grandes utopías ideológicas, que se han asentado como sistemas políticos a escala mundial: la autopía totalitaria de la justicia sin libertad y la autopía radical-liberal de la libertad sin verdad. «Totalitarismos de signo opuesto - los definió el Papa hablando en la Universidad de Vilnius en septiembre de 1993- y democracias enfermas que han desordenado la historia de nuestro siglo» (OR. 5.9.1993).

La libertad sin la verdad — prosigue— madurada en el «hábitat» filosófico del iluminismo ha encontrado su herramienta en el positivismo jurídico, merced al cual los gobernantes de hoy, como Pilato, quieren acallar la propia conciencia no en la verdad objetiva, que asegura la racionalidad de la norma, sino en la verdad convencional, estadística, fruto de la absoluta autonomía del hombre que, olvidadizo de su condición de criatura, opina ser «criterio y norma» de sí mismo. En esto reside la falacia de la autopía jurídica y política de la libertad sin verdad. He dicho falacia porque todo este ordenamiento filosófico social tiene como base el principio apriorístico que «una verdad común y objetiva sea de hecho inaccesible, como se lee en el EV. (n. 68). Me parece lícito preguntarse: ¿puede decirse que esta cultura basada en el absoluto relativismo moral sea una verdadera cultura democrática? Aún más, ¿que sea una verdadera cultura en el sentido más noble de la expresión? No lo es. Por ello, reproducimos las siguientes palabras de la EV.: «El valor de la democracia se mantiene o cae con los valores que encarna y promueve (...) En base de estos valores no pueden estar provisionales y volubles «mayorías» de opinión, sino sólo el reconocimiento de una ley moral objetiva que, en cuanto «ley natural» inscrita en el corazón del hombre, es punto de referencia de la misma ley civil» (n. 70). 
A estas desviadas interpretaciones de la democracia, seguidas por las expansivas ideologías agnósticas y permisivas, se oponen, como atestiguan numerosos autores, Maritain, Del Noce, Cotta o Hervada, las interpretaciones de los clásicos, para quienes «la democracia no es una indiscriminada afirmación de la absoluta autonomía del hombre, sino un ordenamiento social de libertad delimitada por el orden natural». Límites, por lo tanto, no impuestos, autoritariamente desde fuera (tendencia totalitaria) o mediante un simple y omnicomprensivo acuerdo pacticio (tendencia liberal-radical), sino por un orden que tiene un fundamento intrínseco: ética y derecho natural. Límites — ha subrayado- determinados por la misma estructura ontológica de la persona humana: por su naturaleza, es decir, de ser no sólo animal e instintivo, sino inteligente, libre, portador de valores morales y con una dimensión trascendente y religiosa del espíritu que no puede ser ignorada, y mucho menos, violada, por ningún sistema jurídico o político.

Termina Mons. Herranz su exposición, afirmando que la misma Declaración Universal de los Derechos Humanos es un ordenamiento social de libertad que afirma la posibilidad «aún más, la realidad de una verdad objetiva sobre el hombre y sus derechos, el primero, entre todos, el derecho a la vida» y que la negación de la verdad objetiva sobre la dignidad de la persona y sobre el valor de la vida «equivaldría a destruir el fundamento más profundo de la legalidad legislativa y del estado de derecho, abriendo la vía al progresivo desarrollo de una sociedad salvaje ${ }^{2}$.

Mons. Elio Sgreccia, Vice Presidente de la Pontifica Academia por la «Vida», en este cuadro del empirismo jurídico reinante, ha denunciado el peligro que conlleva en el debate bioético la separación entre la moral privada y la ética pública en el ámbito, así llamado, pluralismo ético. De ahí, la urgencia de afirmar la legitimidad de un discurso ético en el ámbito social y su relevancia en el mundo jurídico. De hecho, es inadmisible que, no obstante el continuo progresar de la bioingeniería, el sistema jurídico no haya aún encontrado la normativa precisa de regular las diversas aplicaciones de las conquistas científicas en este sentido, sobre todo, para tutelar la dignidad de la persona. No reconocer, por otra parte, la relevancia de la cuestión ética tanto en el ámbito social como jurídico significaría «avalar la tendencia, según la cual la ley tiende siempre a sustituirse a la moral o, sin rodeos, ser su fundamento constitutivo. En consecuencia, la moral viene a ser siempre considerada socialmente irrelevante en nombre del pluralismo o de lo «privacy» $^{3}$.

2 OR, 24 de mayo 1996, 10.

3 OR., 26 de mayo, 1996, 7. 
2. Con estas premisas de presentación de la temática, tuvo lugar la primera relación por parte de Mons. Carlo Caffarra, titulada «Essere por la Vita: annuncio cristiano e verità della persona nella continuità della Veritatis Splendor ed Evangelium Vitae».

Mons. Caffarra comienza su disertación, distinguiendo dos apartados:

1. ${ }^{\circ}$ Vía teórica de la Encíclica «Veritatis Splendor» y de la «Evangelium Vitae»; 2. ${ }^{\circ}$ Encuentro doctrinal de ambas encíclicas.

1. ${ }^{\circ}$ En la EV. se nos dice que «perdiendo el sentido de Dios, se tiende a perder también el sentido del hombre» (n. 21).

1.1. Este eclipse del sentido de Dios y del hombre conlleva a la violación sistemática del respeto de la vida humana (abortos, eutanasia).

El hombre de la modernidad, al descubrirse como sujeto libre, ha hecho la así llamada tergiversación antropológica, hacia la inmanencia subjetiva, sin trascendencia vertical. Destruyendo la relación con el «Logos» de la realidad como razón fundante de su propio ser: «Soy o no antes Dios», el hombre ha querido afirmar su soberanía absoluta (SV. n. 35). Si se es soberano, el morir depende del mismo ser del que depende el vivir (dominio del nacimiento y de la muerte). Nadie está por encima del hombre y es él el único y solo juez que pueda dictaminar cuándo su vida es digna. Consiguientemente, el hombre se considera como señor del bien y del mal (SV. nn. 32, 35), al que se le confía el deber de justificar la realidad misma.

Esta actitud cultural revela, en primer lugar, la negación de la libertad al no reconocer su vínculo constitutivo con la verdad (EV. n. 19 y SV. n. 33). La verdad del ser se reduce a la conciencia del individuo (concepción radicalmente subjetivista), que, a su vez, es sustituida por el consenso (la mayoría). En segundo lugar, como consecuencia del no reconocimiento de la verdad, una experiencia de libertad autofundante de sí misma, cuyo criterio objetivo no va más allá de sí misma (la verdad es creación de la libertad) (SV. n. 35) y cuyo fin es la consecución del propio bienestar material (EV. n. 23).

1.2. En la SV. se nos dice que las exigencias ineludibles de la dignidad personal de cada hombre están tuteladas por las normas morales, que prohíben sin excepción los actos intrínsecamente malos (SV. nn. 90-95) y que la firmeza de la Iglesia en defenderlas se debe en cuanto «Está sólo al servicio de la verdadera libertad del hombre» (SV. n. 96). He aquí, la conexión entre libertad y verdad.

El «mal intrínseco» es aprehendido por la razón en el mismo ser del hombre ( ratio practica»), e independientemente de las intenciones y circunstancias de quien actúa, afecta al ser mismo de la persona (SV. nn. 79-83). 
De ahí, la intrínseca ligazón entre «ser», «libertad» y «verdad». No hay «ser» sin «libertad»; mas esta libertad, no es ilimitada, tiene sus límites conocidos por la razón práctica. Si todo tiene el mismo valor ( = todo es indiferente) la existencia queda reducida a un juego, en el que se tiende a negar la vía orientadora del intelecto (la razón) al ser (la verdad): el criterio de la verdad sobre el hombre sustituido por «el criterio de la eficiencia, la funcionalidad y la utilidad» (EV. n. 23).

2. ${ }^{\circ}$ Encuentro doctrinal de ambas Encíclicas: en la afirmación de la dignidad de la persona.

En la SV. se nos dice que la libertad depende fundamentalmente de la verdad (SV. n. 34) y en la EV. se enseña que «En realidad, sólo delante del Señor el hombre puede conocer su pecado y percibir toda su gravedad» (EV. n. 21).

La verdad (el bien moral objetivo), que la razón humana puede conocer (SV. nn. 32 y 40), fundamenta la norma en pro de promover el bien perfecto y completo de la persona misma. Esta verdad no está en contradicción con la libertad; al contrario, ofrece las necesarias referencias a cada uno a fin de que pueda juzgar rectamente su elección en orden a su bien perfecto y completo (SV. n. 35).

El ponente manifiesta que en el mundo actual se han aposentado dos actitudes erróneas: una tendencia agnóstica y/o, una tendencia pelagiana.

Citando a Pascal, que afirma que la ruptura relacional hombre-Dios conlleva a que el hombre se desprecie a sí mismo, manifiesta la necesidad de vivir la experiencia hombre-Dios. ¿Cómo? Anunciando el Kerigma del Evangelio, es decir, a Cristo, ayer, hoy y siempre (SV. n. 25). ${ }^{4}$

3. Tras la ponencia se abrió el debate, que giró alrededor de este interrogante: ¿Cómo puede exponerse en el ámbito internacional esta nuestra cultura moral?

Se requiere un proceso - responde el ponente - que convenza que con una antropología individualista, renunciando a la verdad objetiva, plasmada en la acción política, presionada por la base, árbitro moralizante de la sociedad, es imposible alcanzar una vía justa. ¿Cómo ha sido posible el derrumbamiento de ciertas evidencias, v.g., el matrimonio, la familia, etc.? Algo ha pasado. La vía que haga evidente nuestro anuncio no es una demostración documental, sino un compromiso total por la reeducación del ser humano. Esta es la función de la Iglesia.

4 OR., 26 de mayo 1996, 7. 
4. A la tarde, se leyeron dos comunicaciones. La primera de ellas, por el prof. de Historia del Derecho Público de la Iglesia en la Universidad de Strasbourg, Mons. Rolando Minnerath, cuyo título era: "Prospettiva della tradizioni giuridiche circa il diritto alla Vita nei dibattiti internazionali». La segunda, por Mons. Mounged El-Hachem, docente de Derecho Islámico en la Pont. Univ. Lateranense, titulada: "L'esperienza giuridica Islámica de il diritto alla Vita».

Mons. Minnerath desarrolló su comunicación en tres apartados:

1. La protección de la vida en el derecho internacional.

Según el relator, el derecho inalienable a la vida de toda persona humana encabeza las Declaraciones y Convenciones internacionales. El problema estriba cuando se intenta determinar el término «persona». Se nos dice entonces que «persona» se es a partir del nacimiento. Esta es la interpretación oficial dada en 1979 por la Comisión europea de los derechos del hombre, referente al art. 2 de la Convención europea de los derechos del hombre de 1950.

La Comisión, sin embargo, no excluye que el feto no tenga derechos a una cierta protección, v.g., el derecho a la herencia (Causa Brueggermann Sheuten contra Allemagne). En la Convención americana relativa a los derechos del hombre de 1969, en la que los Estados Unidos no se avino a firmarla, se llega a una fórmula de compromiso, en la que se establece, si bien tímidamente, que el derecho de toda persona a la vida (....) debe ser protegido por ley, en general, a partir de la concepción (art. 4), dejando a cada Estado-miembro la decisión de determinar en su legislación interna cuándo comienza la vida.

Cita también la Declaración de los derechos del hombre en el Islam adoptada en El Cairo, en 1990, por los 52 Estados miembros de la Organización de la Conferencia islámica. Esta Declaración afirma que la vida es un don de Dios y el derecho a protegerla (art. 2a), pues la Sharia prescribe la preservación de la vida desde el primer momento hasta su fin, fin que es determinado por Dios (art. b) y en el art. se lee que el niño tiene derechos desde el momento de su nacimiento, pero que el feto y la madre deben recibir una protección y un cuidado especial.

En ningún texto universal o regional, el derecho a la vida es un derecho absoluto. Se alude a la pena capital, legalmente aplicada, como se lee en el Pacto 1966, art. 6,5; la Convención europea (art. 2,2); la Declaración islámica (art. 2b). El estatuto del embrión y del feto no está determinado en las Convenciones internacionales. A cada sistema jurídico, incluso a cada legislador nacional, se le ha confiado concretar las condiciones, en las que la vida antes del nacimiento debe ser «protegida». 
Se nos dice que la primera gran ruptura vida se produjo en 1920 por la URSS de Lenin, seguido del paréntesis del régimen nazi, con sus leyes eugenésicas y el genocidio.

En el mundo soviético iba a nacer una nueva concepción del derecho - manifiesta el relator-, formando la familia de los derechos socialistas, que incluso han dejado sus huellas después de 1989. Este derecho ha sido el primero en despenalizar, después a alentar el aborto, y, finalmente, a planificar por parte del Estado la regulación de los nacimientos y la práctica del aborto.

Desde la Suecia de 1938 hasta la España en 1985, la mayoría de los países occidentales han despenalizado el aborto, bajo el pretexto de evitar las prácticas clandestinas y de someterlo a un control social. En la última década, bajo las presión de los diversos grupos, la opinión ha evolucionado insensiblemente desde la despenalización a la banalización moral del aborto, hasta su reivindicación como derecho de las mujeres de disponer libremente de su cuerpo. Desde esta óptica el aborto es un hecho que queda anclado en la esfera meramente privada. Estas concepciones extremas se han hecho patentes, con más o menos insistencia, en las Conferencias internacionales, de forma notable, la de El Cairo (1994) y de Beijin (1995).

2. Los sistemas jurídicos y el respeto a la vida.

a) Los países de Europa y de América, sellados por la cultura cristiana, el derecho romano-germánico o la commom law, carecen de homogeneidad. En las constituciones de Irlanda y en algunos países latino-americanos se proclama el derecho del ser humano a la vida desde la concepción. En Alemania, el tribunal constitucional de Karsruhe ha dictado una sentencia en 1975, confirmada en 1993, según la cual, el respeto a la vida comienza a partir de la concepción. El aborto es considerado como delito, si bien el Estado renuncia a penalizarlo.

En el otro extremo, la Corte Suprema de los Estados Unidos ha legalizado el aborto, estableciendo en la causa Roe/Wade en 1973 que la vida humana debe entenderse a partir del nacimiento. El 10 de abril de 1996, el Presidente vetó la ley del Congreso que prohibía el aborto después de las veinte semanas, considerándolo como delito de infanticidio.

Ciertos Estados de Europa central y oriental conllevan las huellas de las legislaciones comunistas favorables al aborto, como Eslovenia, que lo considera como derecho en su Constitución de 1991 (art. 55).

b) Los Estados islámicos son los más homogéneos en los debates internacionales. El Corán prohíbe taxativamente el infanticidio (Azora, 6,$141 ; 17,33 ; 60 ; 81,5)$. El hecho que sea menos explícito respecto a la vida del que va a nacer, explica la tolerancia de algunos Estados musulmanes en materia del aborto bajo determinadas condiciones. 
En Africa sub-sahariana, donde la cultura, la naturaleza y las costumbres vigen aún, los conflictos referentes al matrimonio tradicional y a la familia se regulan por los arbitrajes tradicionales, más que por los tribunales. La vida del «nasciturus» es generalmente un valor que hay que respetarlo.

c) En el grupo de las grandes civilizaciones asiáticas, el horizonte normativo es el dharma, o la verdad eterna del orden cósmico, en el que los individuos están insertos, cada uno según su categoría social (las castas). El dharma no conoce la idea de derecho subjetivo. En el flujo continuo de los renacimientos, la persona y la vida no cuentan. No obstante, el budismo ofrece la perspectiva de la emancipación del ciclo de las existencias transitorias por el acceso al nirvana y enseña el respeto de los seres vivos. El hinduismo y el budismo animan a la virtud de la compasión por los seres débiles, considerando inmoral la violencia al «nasciturus» como al anciano. Sin embargo, en India, la legislación tolera la práctica del aborto a gran escala, así como el infanticidio, sobre todo, de las hijas.

d) En el mundo de la China, Japón, Corea, Viet-Nam el pensamiento de Confucio, basado en la persuasión, autocrítica, moderación y conciliación, tiene más calado que las leyes positivas. Es la idea de una armonía cósmica, en la que el hombre debe insertarse por la virtud y la moralidad de sus acciones. Se desconoce la idea de derecho subjetivo.

Desde esta óptica cultural, en China, la vida no tiene valor absoluto. La limitación forzada de los nacimientos y el infanticidio eran prácticas corrientes desde la era imperial. A partir de 1982 una liberación planificadora del Estado ha permitido un despegue económico en las regiones costeras, teniendo como consecuencia el desarrollo de un individualismo violento. Desde 1958 los autoridades han lanzado campañas en pro de la limitación de los nacimientos. La cuarta, en 1979, demanda a un $20 \%$ de las parejas urbanas y a un 5\% de las rurales que limiten su descendencia a un hijo. Las familias con un solo hijo se ven favorecidas. Estas medidas pueden llegar hasta la esterilización forzada. Medidas que van acompañadas por la práctica del aborto y del infanticidio de las hijas para poder transmitir el nombre a un descendiente varón.

En la tradición japonesa, el aborto, cuya primera condena se encuentra en el Código penal de inspiración francesa de 1880, es considerado como inmoral, pero no sancionado por ley. Bajo los Tokugama, siglo XIX,s., el infanticidio se extendía por causa de la pobleza ambiental. La ley de Protección eugenésica de 1948, aún en vigor, invalida el derecho penal y legaliza el aborto. En Japón no se conoce la idea de derecho subjetivo. El individuo adquiere su identidad social en el seno de su familia, el «ie». El derecho es considerado como una coacción de los dirigentes. Las gen- 
tes honestas deben observar los «giri», es decir, las reglas morales arraigadas a la condición de cada uno.

3. ¿Cuál es el consenso internacional?

El pensamiento occidental es faro orientador de los debates internacionales. Los herederos de la «Ilustración» no soportan la idea de que sus conceptos no sean aceptados como universales, cuando al mismo tiempo se expresa por otros continentes el deseo de renegociar una Declaración universal de los derechos del hombre en busca de una vía más respetuosa de la diversidad de los sistemas culturales. La negociación internacional sobre el aborto, intervención sobre el genoma y la eutanasia se pretende en el ámbito universal y regional.

No se debe olvidar que en las reuniones internacionales, los Estados están representados por sus funcionarios, no por los pueblos, las culturas, las civilizaciones, las religiones. Las Conferencias internacionales son acontecimientos políticos.

En dichos ámbitos se busca la vía del consenso, pero como su obtención en el fondo es un ejercicio imposible, se impone, a menudo, satifascerse de un consenso meramente formal. La evolución de las normas internacionales se revela más en lo que no se dice, en los silencios, en los deslizamientos del sentido de las mismas palabras que en las innovaciones espectaculares.

He observado ya - dice el relator-que los Estados nacionales se abstienen de definir los conceptos, a pesar de todo, esenciales. En el ámbito internacional es inevitable que el sentido dado a una misma palabra varíe en los diferentes contextos culturales y jurídicos. Así, el informe explicativo (n. 23) del Proyecto de la Convención europea de bioética constata que los términos de «persona» y de «ser humano» no están definidos, al no existir entre los Estados miembros del Consejo de Europa unanimidad en su definición, conviniendo dejar al derecho interno el sentido eventual de dichos términos. El informe añade «no obstante ha sido constatado como principio generalmente aceptado que la dignidad humana debe ser respetada desde el comienzo de la vida».

Otra tendencia es la de erosionar intencionadamente conceptos en un tiempo indiscutidos. Así, el concepto de familia y de la maternidad.

A los cinco años de la Convención sobre la eliminación de la discriminación respecto a las mujeres de 1979, en la que no se vislumbraba un derecho al aborto, en la Conferencia de México sobre la población, el acento recae en el control de la natalidad como método de la planificación familiar. En 1994, en la Conferencia de El Cairo sobre la población y desarrollo, se alzan voces por abandonar el concepto de «familia» como célula base de la sociedad. Se reconoce «diferentes tipos de familia», proponiendo entre los derechos de la mujer el derecho de decisión, 
eventualmente sola, respecto a la procreación. Se presiona por reconocer como derecho, sin restricción, a escala mundial el derecho al aborto. En Beijin en 1995 no se hace mención alguna de la familia. Más aún, se considera que la familia y la maternidad son obstáculos a la autorealización de las mujeres. Se ha intentado el reconocimiento de la existencia de cinco «géneros» entre los seres humanos, en lugar de los dos sellados por el Creador.

De la misma forma, dos nuevos conceptos aparecen en El Cairo: «reproductive health»y «reproductive rights» («salud reproductiva»y «derechos reproductivos») al margen del matrimonio o de la pareja. La Conferencia de Beijin define la «salud reproductiva» como «un estado de absoluto bienestar físico, mental y social... en todos las campos relacionados con el sistema reproductivo» (n. 94). Se excluye el aborto como método de planificación familiar $(7,24)$; pero forma parte de los derechos reproductivos (7.6)

La imprecisión es, a veces, una condición de la negociación internacional. El proyecto de la Convención europea de bioética mantiene deliberadamente silencio sobre la naturaleza jurídica del embrión humano. El legislador francés ha establecido en 1994 que el ser humano no goza de la cualidad de persona desde de su concepción. Otro país ha propuesto que sea cada nación, conforme a sus «valores espirituales» quien responda a la cuestión «del comienzo de la vida humana». Si bien la Convención propone excluir toda intervención sobre el genoma humano, que tenga como objeto modificar sus caracteres genéticos (art. 14), no ha resuelto el problema de la investigación sobre el embrión humano (art. 17). La misma imprecisión en cuanto a la definición del embrión humano se refleja en el Plan de la Declaración sobre la protección del genoma humano preparado a solicitud de la Unesco por un Comité internacional de bioética.

Los valores reconocidos como el de la dignidad humana pueden también servir para encubrir actos contrarios a la misma. En abril 1991, el Parlamento Europeo presentó una proposición de resolución sobre los cuidados paliativos, en la que se intenta reconocer al médico un derecho de asistencia al enfermo para poner fin a su existencia. La Comisión competente ha reforzado la proposición, precisando que es al médico a quien le pertenece satisfacer todas las demandas del enfermo cuando los cuidados paliativos dejen de ser útiles. El motivo de esta proposición es que la enfermedad puede terminar por destruir toda la dignidad a una persona y, por consiguiente, privarle de su dignidad. En los Países Bajos la eutanasia se practica, a pesar que una proposición de ley en 1987 en pro de la despenalización de la eutanasia fue rechazada. En USA, dos Tribunales federales de Apelación la han legitimado, llamándola «suicidio asistido». 
El ponente termina su exposición aludiendo a la presencia y doctrina de la Iglesia en esos foros internacionales y transcribiendo el nro. 71 de la EV, en el que se enseña: «... la ley civil debe asegurar a todos los miembros de la sociedad el respeto de algunos derechos fundamentales, que pertenecen originariamente a la persona... Entre ellos el primero y fundamental es el derecho inviolable de cada ser humano inocente a la vida.... Si la autoridad pública puede, a veces, renunciar a reprimir aquello que provocaría, de estar prohibido, un daño más grave, sin embargo, nunca puede aceptar legitimar, como derecho de los individuos - aunque éstos fueran la mayoría de los miembros de la sociedad-, la ofensa infligida a otras personas mediante la negación de un derecho suyo tan fundamental como el de la vida».

La segunda comunicación de Mons. Paul-Mounged El-Hachem, «La experiencia jurídica islámica y el derecho a la vida», nos dice que en el tercer proyecto de la Declaración de los derechos del hombre en Islam, adoptado en El Cairo, 4 de agosto de 1990, aún no promulgado, en su art. 2 se constata: a) La vida es un don de Dios y el derecho a la vida está garantizado a cada ser humano; b) Está prohibido el recurso a los medios que pudieran conducir al genocidio; c) La protección de la vida humana, conforme a la voluntad de Dios, es un deber según la Chari'a.; d) La seguridad de no sufrir daños corporales es un derecho garantizado, y el Estado tiene la responsabilidad de proteger este derecho que no se puede violar, salvo si la Chari'a lo permita. Estos principios están reconocidos en las fuentes islámicas: el Corán, la Sunnah y la Jurisprudencia islámica.

Seguidamente el ponente hace alusión a casos concretos:

1. La Jihad y el martirio.

Todos los juristas están de acuerdo que es un deber combatir por Dios.

Aun reconociendo el sentir de algunos juristas que el combate por Dios no busca dañar a los creyentes, ni matar a los adversarios y su fin es convertir a los enemigos al Islam, es necesario, también, reconocer que en este combate la libertad de adhesión al Islam brilla por su ausencia.

Es verdad, sin embargo, que el Jihad predicado por el Islam no autoriza matar. La guerra tiene sus reglas que hay que respetarlas. Así, el art. 3 del tercer proyecto de la Declaración de los derechos del hombre en Islam de la L'OCI formula estas reglas: «No está permitido, en el caso de la utilización de la fuerza o de conflicto armado, matar a las ancianos, mujeres y niños. Los heridos y los enfermos tendrán derecho a la asistencia sanitaria; los prisioneros de guerra tendrán derecho al alimento, abrigo, y vestidos. Se prohíbe la mutilación de cadáveres. Es un deber el intercambio de prisioneros». Todo esto indica un respeto a la vida, si no es radical, al menos, bastante importante. 
Desde este prisma, el Islam, que persigue salvar la vida de los creyentes, no impide glorificar a los mártires, que desean morir por sus creencias. Es necesario, no obstante, reconocer que en el derecho islámico, el martirio no hay que buscarlo por el martirio mismo. La muerte no puede ser deseada como tal, conforme a la palabra de Mahoma: «No deseéis la muerte, pero si la encontráis, sed firmes».

Si el deber del mulsumán es velar por su propia vida y actuar con el enemigo según la Chari’a divina, ¿cómo debe comportarse frente a la vida del ser humano?

2. El control de la natalidad.

El ponente, citando los textos sagrados, dice que la limitación de los nacimientos es considerada naturalmente como debilitamiento de la nación islámica, que tiene necesidad de capital humano para luchar contra sus enemigos, pasados y presentes. Es, igualmente, considerado como castigo divino: «Os probaremos con algo de temor, de hambre, de disminución de vuestros bienes, personas y frutos» (Corán, 2,155). Aun más, el hecho de la limitación de los nacimientos es concebido como complot de los colonizadores contra la nación islámica.

Teniendo en cuenta — dice- que la ley islámica impulsa a multiplicar los nacimientos, considerando que son una gracia eminente y un don superior que Allah otorga a sus servidores; que las tesis a favor de la limitación son contrarias a la sana naturaleza humana («fitra»); que sus partidarios constituyen un grupo que confabula contra los musulmanes en general y contra la nación árabe-musulman, en particular, de forma que puedan imponer sus tesis colonialistas a los países (musulmanes) y sus habitantes, y porque en estas tesis existe una especie de prácticas dignas de la Jâhilyya, una malvada opinión del mismo Allah y un debilitamiento evidente de la sociedad islámica, que se funda en el nombre y la solidaridad de sus rocas humanas, el Consejo ha decidido que es absolutamente ilícito limitar los nacimientos. (Resolución n. 42 en la fecha del 3.4.1396, en la semana árabe de la Rábita (La Mecque).

El ponente dice que los partidarios en pro de la limitación tienen a bien recurrir a versículos que sostienen la cualidad contra la cantidad (Corán 102:12; 4:3; 64:14-15), a los Hadiths que van en esta línea y parecen, en nombre de una cierta clemencia, permitir el control de la natalidad. En definitiva, la ley de la necesidad legitima la infracción de las prohibiciones, a menudo, invocada por la jurisprudencia.

El Corán inculpa, en realidad, a una costumbre del infanticidio (wa'd) practicado en la Jâhiliayya por temor a pobreza y a la miseria (imlâq), y exalta a Allah como gran el Proveedor: «Quien da el sustento, el Dueño de la fuerza, el Inamovible» (51:52); «no mataréis a vuestros hijos por temor de la miseria: nosotros proveeremos a vosotros y a ellos» $(6,151)$. 
El ponente dice que la actitud del Islam respecto al control de la natalidad puede resumirse en una decisión en cuatro puntos tomada por la Academia de investigaciones islámicas, en la reunión tenida en El Cairo, en la que han participado representantes de 35 países musulmanes en 1965:

«1. El Islam impulsa el aumento de la prole y su multiplicación, porque refuerza la comunidad islámica tanto en lo social, económico y militar.

2. En caso de necesidad, nadie impondrá la planificación de la prole, los esposos deben atenerse a esta necesidad, según su conciencia individual y sus creencias.

3. Se prohíbe, según el derecho musulmán, promulgar leyes que impongan a la gentes la limitación de la prole bajo cualquier forma.

4. El aborto, en aras de la limitación de la prole, no deberá practicarse ni por los esposos ni por terceros. La Academia recomienda la concienciación y ayuda a los ciudadanos» (Décision dans Bar: Siyassat, p. 450. En otras faatwas, pp. 451-455. cf. Sami, ídem, p. 53).

\section{El aborto.}

En realidad, lo anteriormente dicho es válido respecto al aborto. Es necesario, sin embargo, reconocer que el aborto encierra una nueva responsabilidad a los ojos del Islam. El art. 7 de la Declaración de los derechos del hombre en Islam de la L'OCI afirma: «Todo niño, desde el momento de su nacimiento, tiene derecho a los cuidados apropiados, a la educación, al sostenimiento material y moral de sus padres, de la sociedad y del Estado. La madre y el feto recibirán protección y tratamiento especial durante el período de la maternidad» (en Conscience et liberté 41/1991, p. 112). ¿Qué entiende el Islam por feto?

El ponente, tras afirmar la creencia del Islam en la formación progresiva del feto y en la insuflación tardía de la vida en este feto, cita con Saleh al Fawzan la resolución emitida a este respecto por el consejo de la Asamblea de los Grandes Doctores de la ley, en fecha 20-6-1407 (1987/1988):

«1) No es lícito expulsar el embrión en ninguna de las etapas del embarazo, a no ser que una causa conforme a la ley lo justifique, pero siempre en los límites más estrictos del caso examinado.

2) Si el embrión se encuentra en su primera etapa, a saber, en sus primeros cuarenta días, y si existe, a raíz de su expulsión, algún beneficio reconocido por la ley o la necesidad de evitar algún daño, esto es lícito. Mas la expulsión, en este primer período, por la simple razón que hubiera dificultad de educar a los niños o que se temiera ser incapaz de poder sustentar e instruir, o bien porque se tratara de su porvenir o porque se quisiera limitarse a los hijos, que los esposos han engendrado, (esto) no es lícito. 
3) No es lícito expulsar el embrión desde que está en un estado de adherencia (!alaqa) o de masa floja (mudga), hasta que un equipo médico agregado no haya determinado que su conservación conlleva peligro para la salud de la madre, al temerse su muerte: es lícito expulsarlo después de haber agotado otros medios posibles para evitar el peligro corrido por la madre.

4) Cuando la tercera etapa (de la formación) ha terminado y cuando el embrión está al final de su cuarto mes, no es lícito expulsarlo hasta que un equipo de médicos especialistas y agregados no haya establecido que la conservación misma del feto en el vientre de su madre causaría la muerte de ésta, y esto después de haber agotado todos los medios posibles para salvaguardar la vida.

La autorización de expulsar el feto en tales condiciones es concedida por evitar, entre dos males, el más grave y por garantizar el mejor de los dos bienes (a considerar)». (en L'hebdomadaire Akhbâr al-Alam al-islàmi, La Mecque, 5-9-94).

El aborto, por lo tanto, está prohibido; los casos difieren durante los cuatro primeros meses de la vida uterina o después; según sea el caso, se sanciona en el ámbito religioso, penal y temporal, sanciones determinadas por la Ley islámica. feto?

¿El aborto es permitido cuando se descubre una deformación del

El ponente cita la opinión del Consejo de la Academia de Derecho Islámico de la Liga del Mundo Islámico, en su 12 sesión habida en La Mecque, sábado 10 al 17 e febrero 1990: «Si el feto ha llegado a los 120 días no es lícito expulsarlo, aun en el caso de un diagnóstico médico que prevé que su conformación será defectuosa; a no ser que un informe de un equipo médico compuesto por especialistas certifique que su conservación constituye un peligro para la vida de la madre....». En el caso que sea antes de los 120 días, es lícito expulsar el feto siempre que el informe médico certifique que no hay esperanza alguna de tratamiento y curación y que, si nace, conocerá una de las vidas más dolorosas plagada de sufrimientos para él y su familia (en L'hebdomadaireAkhbâr al-Alam alislàmi, La Mecque, 5.9.1994).

4. La esterilización.

Como vemos, el aborto está sancionado y autorizado solamente en el caso de necesidad (peligro de la vida de la madre). ¿En el caso del descubrimiento de algunas taras hereditarias en una concepción posible, se autoriza no sólo la expulsión del feto por estado de necesidad, sino, también, para prevenir tal situación, el recurso a la esterilización?

El Cheikh de la Universidad Al-Azhar responde a este interrogante: Cuando nos remitimos al Sto. Corán y a la Noble Sunna, no encontramos 
en ninguno de estos textos un texto concreto claro que prohíba la esterilización. Mas los textos, de carácter general, tanto en el Corán como en la Sunna la rechazan y la prohíben.

«Aplicando tales textos, la asamblea de jurisconsultos declara, pues, que la esterilización está prohibida por la ley islámica si no existe necesidad alguna, en cuanto se trata de suprimir los nacimientos (pontenciales), lo que atenta a la necesidad de salvaguardar la reproducción de la especie (humana), una de las cinco necesidades que el Islam considera que constituyen las finalidades (maqâsid) esenciales de la legislación en sus cualificaciones ético-jurídicas» (en L'hebdomadaire Akhbar al-Alam al-islàmi, La Mecque, 5-9-1994).

El ponente manifiesta que no existe unanimidad en la praxis como en la doctrina respecto a la esterilización. Unos, la justifican en la Chari'a (en Sami, ídem. pp. 74-75; 80-81-82), otros, se oponen, basándose en la bondad de la creación (Corán 32:7). De hecho, el objetivo del Islam en sus actitudes, flexibles y maleables, es el de asegurar el bien del hombre. Es verdad, sin embargo, que los textos islámicos insisten continuamente sobre el respeto de la vida y la de la naturaleza, cuya alteración se considera como obra del diablo (Corán 4:118-119). Aun más, ciertas investigaciones de la genética moderna no se admiten por la jurisprudencia islámica, a no ser dentro de los límites de la moral islámica. Así, la inseminación artificial se admite en los casos de necesidad y conforme a las normas generales del matrimonio, de los derechos de paternidad y de maternidad y de la herencia.

Las recomendaciones de una conferencia sobre la procreación a la luz del Islam afirman a propósito de la inseminación artificial:

1) La licitud de la inseminación artificial cuando tiene como objetivo satisfacer la necesidad de la mujer casada que no concibe y la necesidad de tener un hijo por parte de su marido.

2) El primer método, por el que se toma el esperma de un hombre casado y se inyecta en el útero de su mujer, siguiendo ella misma el método de la inseminación interna, es un método permitido por la Chari'a, dentro de las condiciones generales establecidas y siempre que se confirme la necesidad de esta operación por parte de la mujer en pro de la concepción.

3) El tercer método, según el cual se toma el esperma y el óvulo de un hombre y de un mujer casados entre sí, y se les fecunda por la inseminación in vitro, después se transplanta el óvulo fecundado en el útero de la mujer donante del óvulo, es un método admitido, en principio, en tanto en cuanto tal; mas dadas las dudas que entraña, por las confusiones que la acompañan, no se debe recurrir mas que en el caso de necesidad extrema, habiendo asegurado los requisitos generales establecidos. 
4) El séptimo método, según el cual se toma el esperma y el óvulo de una pareja casada y después de la fecundación in vitro, se insemina el óvulo fecundado en el útero de la otra mujer del marido mismo, que se propone libremente por esta concepción, parece al Consejo de la Asamblea lícito, en el caso de necesidad y en las condiciones generales determinadas. (La procreation dans l'Islam, Conference tenue au $\mathrm{Ku}-$ weit, 24 de mayo 1983, p. 480-481).

Todos los demás casos son rechazados por respecto a la moral islámica.

En cuanto a la eutanasia, el ponente dice que lo que interesa es saber que el Islam tiene sus propias concepciones del comienzo y fin de la vida. Tiene su propia moral de la vida que esencialmente la respeta.

5. El sistema penal musulmán.

El ponente dice que los textos de la Chari' a admiten la ley de talión y tipifican como delitos, por ejemplo, el adulterio que da lugar a la flagelación, incluso para quien lo denuncia y no prueba, y en ciertas condiciones por la misma causa da lugar a la lapidación. Se considera como delitos el bandidaje, la insurrección armada y el atentado a la integridad física, que conlleva a la amputación.

En relación a pena capital, el Islam — dice — la defiende con el mismo vigor que defiende la vida.

Termina su comunicación diciéndonos que el Islam respeta ciertamente la vida como sagrada. Pero que tiene sus propias concepciones referentes al comienzo de la vida, su evolución y su fin, lo que refleja su actitud ante el aborto y ciertas conductas que representan para nosotros atentados a la vida. Tiene sus nociones propias que conciernen el sistema penal, el derecho y el mismo deber de la guerra, así como una concepción propia de la necesidad que legitima ciertas actitudes que parecerían a otros ofensivas. Lo importante es el de poder llegar, con el concurso de la ciencia y el progreso, a un cierto acercamiento conceptual, que repercutirían en las actitudes fundamentales frente a la vida.

5. Ponente de la tercera relación fue el prof. de Filosofía del Derecho, D. Pedro Serna: "La Vita come problema di giustizia: il contributo dell'Enciclica alla civiltà del Diritto» .

Se propone mostrar las aportaciones nucleares de la EV desde el punto de vista del Derecho. Su ponencia la divide en cuatro apartados:

1. Contradicciones en la cultura de los derechos humanos.

El ponente comienza su disertación, afirmando la contradicción expresamente palpada en la EV. entre la reivindicación de la libertad, de la democracia y de los derechos humanos, por una parte, y las violaciones y amenazas contra la vida, por otra, de forma que en el ejercicio de los de- 
rechos de libertad se pretende la violación del derecho a existir de determinados grupos de seres humanos (EV. n. 13-17).

Si se niega la universalidad de los derechos, anteponiendo la libertad y el bienestar de unos sobre la vida de los otros, precisamente de los débiles, equivale a negar la igualdad y a introducir diversas categorías entre los seres humanos. Esto es lo que significa propiamente la «sociedad de excluidos», que se menciona en la Encíclica.

En nuestros días - dice- el fenómeno de la exclusión aparece en los más diversos ámbitos, como consecuencia de un pensamiento científico, político y económico disyuntivo, acostumbrado a pensar las relaciones sociales como juegos de suma cero. Es el resultado de una lógica que afecta principalmente a los que dejarán de vivir para garantizar el bienestar o la libertad de otros, pero también a quienes vivirán peor, en condiciones infrahumanas.

Este es uno de los principales problemas de nuestros días: la universalidad expansiva de los ideales modernos del progreso material y de la libertad individual, que resulta imposible de alcanzar si se mantienen las actuales características del tecnosistema que integran el Estado y el mercado.

El ponente, aludiendo al modelo económico capitalista, impotente para evitar la exclusión social, y a los ataques contra la vida llevados a cabo en nombre de la libertad, manifiesta que se introduce el criterio de la fuerza como patrón de la convivencia. Cuando, además, se pretende llevarlo mediante instrumentos jurídicos, el ordenamiento jurídico queda invadido por ese déficit de civilización. Al modo de ver del ponente se trata de una violencia refinada, situándonos en las antípodas no sólo de la justicia, sino de la misma idea de Derecho.

2. El diagnóstico de una situación: Desenfoque en la imagen de la dignidad y la libertad.

Para Juan Pablo II, pretender que la libertad humana se puede extender legítimamente hasta incluir un supuesto derecho a privar de la vida a otros seres humanos sólo se explica por una comprensión defectuosa de la dignidad de la persona humana, por una parte, y de la libertad que le es connatural, por otra (n. 19). Es preciso negar la dignidad de las víctimas y ampliar notablemente el alcance del uso legítimo de la libertad a quienes realizan la agresión.

La Encíclica señala que el concepto de dignidad personal que se requiere para ello es aquél que la identifica con la autonomía (Ib.). Otra concepción que niega la dignidad al débil prosigue el Papa, es aquella que «tiende a identificar la dignidad personal con la capacidad de comunicación verbal y explícita» y, en todo caso, experimental ( $I b$.)

Respecto al concepto de libertad, es aquél «que exalta de modo absoluto al individuo, y no lo dispone a la solidaridad, a la plena acogida y 
servicio del otro (....) una visión de la libertad muy individualista, que acaba por ser la libertad de los "más fuertes" contra los débiles destinados a sucumbir» (Ib.).

El ponente, tras esta citación del texto n.19 de la EV., dice, refiriéndose al concepto de «dignidad», que la absolutización de la autonomía no es criterio limitador ni orientador para la praxis humana. Por otra parte, quien no es autónomo queda en una posición semejante a la del universo natural, asimilado a un objeto en el espacio, donde se despliega la actividad del sujeto autónomo, que puede ser removido en el caso que obstaculice dicho despliegue. Como se señala en la EV., ello se muestra en abierta contradicción con la teoría de los derechos humanos, que «se fundamenta precisamente en la consideración del hecho que el hombre, a diferencia de los animales y las cosas, no puede ser sometido al dominio de nadie» (n.19) En consecuencia, ¿cómo conciliar esta postura con la exaltación del hombre como indisponible? (Ib.).

Ante esta denuncia implícita en esta pregunta se podría contraargumentar declarando el carácter sólo aparente de la disposición sobre el ser humano en los casos de aborto y eutanasia, por ejemplo: dicho carácter se haría visible si se considera que no se trata de sujetos propiamente humanos. El ser no autónomo no sería humano y, en consecuencia, no poseería derecho alguno. Pues bien, para el ponente, al afirmar esto es cuando se entra en colisión frontal con la teoría de los derechos humanos, pues no hay acto más fuerte de disposición sobre un ser humano que establecer si lo es o no. Caracterizar la dignidad humana en términos de autonomía, pretendiendo constituirse en criterio para determinar quién es ser humano y quién no lo es, constituye un auténtico acto de poder que viola la misma dignidad humana entendida como exigencia de no disposición, de respeto al «fin en sí mismo». Y desde aquí puede entenderse - continúa el ponente - el alcance filosófico y jurídico de la propuesta contenida en la Encíclica, en orden a considerar intrínsecamente valiosa toda vida humana.

Por análogas razones puede discutirse el segundo concepto de dignidad, que la entiende vinculada esencialmente a la capacidad de expresión, al logos verbal fácticamente poseído.

Respecto al concepto de libertad, en la EV. se pone de relieve que se trata de una libertad desnaturalizada, separada del propio hombre y de todo vínculo constitutivo con la verdad (n. 19).

Se trata de una libertad que ha dejado de ser un bien, para convertirse en un valor, que será reivindicado en y desde sí mismo y, por ello carecerá de límites y fundamento. Las consecuencias de esta desnaturalización, aludidas en la EV. (n. 20), nos lleva en el plano estrictamente personal a la amarga experiencia del existencialismo (si no hay naturaleza, cual- 
quier uso posible de libertad será correcto) y, en el plano político, a una suerte de politeísmo axiológico, que desemboca en la guerra de unos contra otros y en la imposibilidad de encontrar más criterios de armonización que la arbitrariedad resultante del juego de las fuerzas.

En el mundo del derecho se acusa también estas consecuencias. Por una parte, se establece una jerarquía entre los diferentes derechos, que no infrecuentemente oculta una jerarquización entre las personas. Por otra, se intenta el recurso a una ponderación entre los intereses en juego que fácilmente incurre en la arbitrariedad, al no disponer de referente metapositivo. El formalismo jurídico dificulta aún más las cosas, pues el criterio invocado para la valoración constitucional de las conductas es «la regla de las mayorías», olvidándose que los derechos fundamentales valen precisamente en la medida que constituyen límites al poder, ya provenga éste de las mayorías o de cualquier otra instancia. No valen en virtud del pluralismo, ni de la tolerancia, sino como límite de las expresiones legítimas de ambos.

3. En el horizonte de una crisis profunda.

El ponente apunta algunos corolarios que cabría obtener de la lectura de los nn. 21 y 22 de la EV.:

1) La desaparición del Absoluto, o su relegamiento al ámbito completamente privado, al fondo de la conciencia individual, hacen absurdo, por inviable, aspirar a una defensa del valor incondicional de la persona.

2) La ausencia del Absoluto no es originaria, sino originada por una realidad estrictamente personal, que es el alejamiento voluntario por parte del hombre. Desde este alejamiento voluntario se pierde la referencia a lo divino, y el resto del universo queda afectado por una radical indiferencia. A partir de este contexto todo queda unificado bajo la forma de no-yo, formando un horizonte uniforme, potencialmente reducido a la condición de cosa, de campo para el despliegue de la actividad del yo, sobre el que habrá de ejercitarse la afirmación de sí mismo.

3) De lo dicho se desprende que no es correcto trazar una separación completa entre el desorden moral interior y el externo. La justicia se ve amenazada cuando las demás virtudes lo están. Por ello, aunque es posible hablar de virtudes públicas, no puede señalarse ninguna que sea absolutamente privada, incluso en lo relativo a sus efectos inmediatos. $\mathrm{Si}$ bien es verdad que no toda la moral es exigible institucional y coactivamente, jurídicamente, también es verdad que la llamada ética privada sea completamente ajena a la suerte de las comunidades políticas. La relevancia política de la presencia social de la idea de lo Absoluto, por una parte, y de la moral personal de los ciudadanos, por otra, constituye otra aportación destacable de la Encíclica, cuya traducción jurídico-constitucional apunta en la dirección de una democracia no relativista, posible y 
deseable, de una comunidad política que renuncie constitucionalmente al principio de la soberanía absoluta, en beneficio de límites infranqueables por la decisión de los poderes constituidos, límites que coinciden con los derechos fundamentales.

4. La dimensión jurídica de las propuestas positivas de la Encíclica.

4.1. Un nuevo fundamento para la dignidad humana.

El fundamento del carácter de «res sacra» del hombre que se pretende postular cuando se habla de dignidad se encuentra en su relación con el Absoluto. Por eso, la idea de dignidad no tiene sentido fuera de una metafísica de la creación. Desde estas coordenadas la racionalidad del hombre se revela como el signo de una llamada del Absoluto, contenida en el propio designio creador. Esta relación desde el Absoluto nos sitúa más allá del plano puramente óntico y nos transporta a un ámbito metafísico-teológico. Según el ponente, esta fundamentación metafísica-teológica de la dignidad está insinuada en la EV. n. 2 y, a su juicio, el reconocimiento de la condición criatural de uno mismo y de los semejantes es precisamente lo que conduce a relativizar las propias pretensiones de actuación sobre naturaleza y sobre los restantes seres humanos, y a convertir a éstos en destinatarios de un respeto que no se hace depender de condiciones.

4.2. El valor de toda vida humana.

De lo anterior se desprende el valor de cada vida humana.

La vida humana no puede ser objeto de disposición, ni por parte de la comunidad política, ni tampoco por parte de sí mismo. El derecho a la vida es, propiamente un derecho inalienable. En rigor, también serán inalienables todos los derechos pertenecientes a la categoría de los derechos humanos. La regla de la inalienabilidad sólo admite la excepción de la legítima defensa, tema - dice- del que no puede ocuparse.

Ese carácter no disponible, fruto de la exigencia de respeto derivada de la dignidad, obliga al ordenamiento jurídico a abstenerse de fijar cualquier criterio convencional sobre el comienzo del derecho a la vida. Ello no obsta que en el ámbito estrictamente patrimonial se mantengan antiguas reglas jurídicas que vinculan el comienzo de la personalidad con el hecho de nacimiento.

Finalmente, el derecho a la vida reclama del ordenamiento la máxima protección. La despenalización no es el camino para conseguir este objetivo, además de contribuir a difundir una relativización del valor de la vida. Según el ponente la Teoría contemporánea del Delito dispone de los recursos suficientes para resolver con justicia la causa de aquellas mujeres, cuya responsabilidad criminal se haya atenuada en virtud de las circunstancias que la llevan a someterse a un aborto voluntario. 


\subsection{Libertad y naturaleza.}

La libertad política y jurídica se despliega en un conjunto de libertades, cuya medida depende de un ajuste dinámico y encuentra su principal criterio de limitación interna y de armonización con las libertades y derechos de los demás en un «contenido esencial» definido a partir del fin de cada derecho.

Si se introduce la idea de naturaleza humana en el tratamiento de la libertad, ésta se encontrará esencialmente abierta a la verdad y limitada por ella, tanto en su dimensión personal como en su despliegue político y social, como se sugiere en la EV.

6. En el debate se le cuestiona al ponente, que parece seguir la escuela de Hervada, sobre el concepto de «personalidad». ¿Dónde está el personalismo? Todo ser humano es persona en el plano ontológico y, por lo tanto, lo es en lo jurídico.

R.-En mi exposición hablo de los deberes («no matarás»), que tienen su origen en la persona.

Se hace alusión a la pena capital: Si el derecho es expresión del valor de la persona. Si el derecho se enraiza en la libertad, ¿cómo puede justificarse la pena capital?

Se dice que la cultura laica cae en contradicción, pues, por una parte desprecia el inicio de la vida humana y, por otra, es contraria a la pena capital

R.-Existe dicha contradicción originada por la ausencia del Absoluto, que permite la desaparición del no nacido.

Respecto a la pena capital, me atengo al Catecismo de la Iglesia Católica, por lo que sólo es posible en la legítima defensa.

Varias voces se alzan oponiéndose a la pena capital, pues el delincuente tiene un derecho como persona, sin merma de su dignidad. Además, no se ve que hoy existan casos de absoluta necesidad, que legitimen la pena capital.

Otra de las preguntas hace referencia al espíritu kantiano acerca de la dignidad humana. Según el ponente, fuera de la teología no hay respuesta. Cree el interpelante que partir de la teología es partir desde una opción particular.

R.-La experiencia alemana muestra la pérdida del Absoluto. Desde la concepción kantiana no se justifica el «fin en sí mismo».

7. Se da lectura a dos comunicaciones. Una hace referencia al Riesgo discriminatorio y selectivo en ingeniería genética y procreación artificial y la siguiente a la Objeción de conciencia.

El ponente de la primera comunicación es el Dr. W.M.O. Moore, Asesor de Obstetricia de Bupa Medico-Legal Services. Presidente del Linacre Centre For Healthcare Ethics. 
El ponente pretende informar sobre el diagnóstico genético llevado a cabo con prácticas clínicas asociadas a la procreación artificial. Si bien, el conocimiento genético, como todo conocimiento, puede ser mal empleado, también puede aportar grandes beneficios a la sociedad. El desafío consiste en asegurar que la humanidad goce de sus beneficios y rechace sus abusos.

Manifiesta desde el comienzo que lo que va a exponer es contrario al magisterio de la Iglesia. Aparte del hecho que las técnicas de reproducción artificial son moralmente inaceptables, desde el momento que separan la procreación del contexto plenamente humano del acto conyugal, el número de embriones producidos es frecuentemente mayor que los que hacen falta para la implantación en el útero de la mujer. Además, algunos embriones se someten a pruebas que no van dirigidas a mejorar sus condiciones de salud o su supervivencia individual.

Plantea el sufrimiento de las parejas con riesgo de tener un hijo con una enfermedad genética. En la actualidad, en el mundo occidental - dice-, si una pareja quiere tener un hijo con estas perspectivas, tiene las siguientes opciones: $1 .^{\circ}$ Evitar concebir un hijo; $2 .^{\circ}$ Adoptar un niño; $3 .^{\circ}$ Correr el riesgo y esperar que el hijo que conciban no esté afectado por la enfermedad; $4 .^{\circ}$ Hacer pruebas al feto durante la gestación y considerar la opción del aborto.

En un futuro cercano las parejas tendrán una opción más, porque después de muchos experimentos con embriones humanos producidos por fecundación in vitro (en adelante IVF = «in vitro fertilisation») la posibilidad de escoger embriones libres de cualquier enfermedad genética particular se ha convertido en una realidad.

Acto seguido expone las razones de esta opción.

Cuando la fecundación se realiza naturalmente in vivo, el espermatozoide y el óvulo se encuentran y se unen en la trompa de Falopio (oviducto). En los días siguientes el embrión crece y baja de la trompa de Falopio para alcanzar el útero, donde queda implantado cinco o seis días más tarde.

En la IVF se emplea el mismo esquema temporal: el embrión formado en tubo de ensayo es trasladado por vía vaginal al útero seis días más tarde. De este modo la unión de IVF con la nueva genética molecular ofrece la oportunidad de un diagnóstico genético antes de la implantación.

La experiencia fiable del diagnóstico previo a la implantación (en adelante PID = pre-implantación diagnosis) está basado en los programas de IVF, pues proporcionan un esquema de trabajo clínicamente muy apropiado.

La práctica actual del PID implica lo siguiente: 
1. Quitar una sola célula de un embrión de 4 células, o 2 células de un embrión de 8 células, a los dos días, o

2. Biopsia de la trofectoderma (capa de células destinadas a convertirse en placenta) de un embrión de 5 días, que contiene unas 200 células.

La técnica es extremadamente sencilla. Las células separadas por la biopsia son sometidas a distintas pruebas, según la anomalía que se intenta detectar. Es práctico tener la respuesta el mismo día, de modo que los embriones seleccionados puedan ser llevados al útero no más tarde de lo que serían en un tratamiento rutinario de IVF.

Sorprendentemente, no hay muestras que la biopsia del embrión comprometa su posterior desarrollo ni que reduzca la tasa de gestaciones que llegan a buen término después de la implantación. Si el embrión sufriera daño durante el proceso de la biopsia, el resultado sería su no implantación (muerte del embrión) y no, por lo tanto, anomalías estructurales en el parto.

Los estudios más recientes indican que la biopsia de una cuarta parte de la masa celular del embrión a los tres días es el momento óptimo para la fiabilidad del análisis genético y el posterior desarrollo del concebido.

Sería muy engañoso dar la impresión de que el PID es sencillo de llevarse a cabo y libre de error. Ya ha habido errores. En el Reino Unido uno de cada siete fetos procedentes de embriones diagnosticados como hembras y exentos de anomalías genéticas específicas resultaron ser varones, cuando se les sometió a pruebas más tarde en la gestación. Las parejas decidieron terminar la gestación mediante aborto. En los Estados Unidos uno de cada cinco embarazos comprobados, iniciados supuestamente con embriones exentos de anomalía genética específica demostró ser un feto homocigoto en relación con la fibrosis quística.

Los errores se debieron probablemente a la aplicación de nuevos métodos, antes de haberse demostrado que eran suficientemente fiables. Harán falta muchas pruebas con embriones humanos para estar seguros de que el análisis genético es inequívocamente preciso y de que el nivel de riesgo que implica todo el proceso es bajo.

De las más de 4.000 anomalías genéticas conocidas, algunas son más comunes que otras. En conjunto, alrededor de un uno por cien de niños que nacen vivos están afectados por una enfermedad genética seria. Hasta ahora el PID se ha realizado en embriones humanos obtenidos por IVF de pacientes afectados de fibrosis quística, enfermedad de Huntington, distrofia muscular de Duchenne y un puñado de raros defectos de un solo gene. Solamente las más graves anomalías de un solo gene son las candidatas para el PID en este momento.

Si el defecto genético es recesivo y ambos progenitores poseen el mismo defecto recesivo de un solo gene, transmitirán la enfermedad, por 
término medio, a uno de cada cuatro de sus hijos. Ejemplo: la fibrosis quística, que afecta a uno de cada 2.000 nacimientos en el Reino Unido. Se trata de una enfermedad pulmonar crónica y, a la larga, fatal.

Si el defecto genético que está en uno de los progenitores es dominante, la mitad de los hijos, por témino medio, de esa pareja heredarán el gene. Ejemplo: la enfermedad de Huntington, que afecta a uno de cada 10.000 nacimientos en el Reino Unido; el $99 \%$ de los niños que heredan este gene eventualmente desarrollan un estado caracterizado por una incapacidad progresiva y sin remisiones que, finalmente, conduce a una demencia precoz.

Si el defecto genético está en uno de los crosomas sexuales de los padres (cromosoma X), afecta solamente a los hijos del mismo sexo. Ejemplo: la atrofia muscular de Duchenne, que afecta a 1 de 4.000 varones (son raros los casos en los que las afectadas sean mujeres) en el Reino Unido; la enfermedad se caracteriza por una progresiva degeneración muscular y un debilitamiento que lleva a la muerte por fallo del corazón.

La demanda del PID crecerá inevitablemente, porque ofrece a las parejas, que tienen alto riesgo de trasmitir una enfermedad genética, la oportunidad de un diagnóstico antes que comience en el útero la gestación. La disponibilidad simultánea de varios embriones procedentes de la IVF hace posible descubrir embriones exentos de defectos genéticos específicos para implantarlos en el útero.

Lo que está teniendo lugar es una revolución ética, que trasciende los límites de cualquier país. En estos momentos no existe en Europa un consenso, en cuanto el uso de la IVF para el PID. En el Reino Unido está regulado por la «Human Fertility and Embryology Authority», la cual prohíbe la manipulación de la estructura genética del embrión, los intentos de clonación, la mezcla de células humanas y de animales en el desarrollo del embrión, y en el uso de las técnicas que permiten a las parejas escoger el sexo de sus hijos, excepto en los casos de enfermedades vinculadas al cromosoma X. En Francia puede decirse que la legislación inicial, que declaraba ilegal el PID se va suavizando en los casos graves de enfermedades hereditarias. En Alemania está totalmente prohibido. Mi opinión es que muchas de las restricciones actuales serán eliminadas en los próximos años.

Alude a la Comisión Europea, que ha establecido un Comité de representantes de cada Estado miembro para examinar las consecuencias éticas, legales y sociales de los programas de las ciencias de la vida en su Framework Programme for Researh and Development. Este Comité asegurará que haya una efectiva coordinación entre los programas y que las actividades se ajusten a las regulaciones que sean necesarias. 
La segunda comunicación del prof. de Derecho Eclesiástico en la Facultad de Derecho en la Universidad de Turín, Dr. Vicenzo Turchi, referente a la objeción de conciencia, da inicio, afirmando que la objeción de conciencia, entendida como derecho subjetivo connatural a la persona parezca, a primera vista, como una adquisición relativamente reciente por parte del magisterio de la Iglesia, las fuentes históricas y teológicas del magisterio al respecto son antiquísimas y radicadas tanto en la Escritura como en la Tradición, sobre todo, a partir de la revelación neotestamentaria, donde la conciencia informada por el espíritu de la Ley Nueva, perentoriamente, reclama «oportet oboedire Deo magis quam hominibus».

Haciendo un breve recorrido de la historia sucesiva de la Iglesia, desde las persecuciones de los primeros siglos hasta Sto. Tomás Moro, testigo de la verdad del derecho contra la injusticia de un imperativo legal, y, citando a Gelasio I, a Inocencio III, S. Buenaventura, Sto. Tomás de Aquino, en cuyos textos se reconoce el valor primario de la conciencia, se detiene, como punto de reflexión crítica e investigación cultural, en la nota pastoral de la Conferencia Episcopal Italiana, «Educare alla legalità», del 4 de octubre 1991. En un contexto general, dedicado a la necesidad de desarrollar «una renovada cultura de la norma», de educar «por un sentido más maduro de la legalidad», se declara — dice— la objeción de conciencia, como «algo de extrema seriedad», en cuanto se «conecta a una precisa antropología personalista, rechaza toda concepción totalitaria del Estado, apunta decisivamente sobre la íntima conexión entre legalidad y moralidad»; la objeción de conciencia se enraíza no en la autonomía absoluta del sujeto respecto a la norma y, mucho menos, en el desprecio de la ley del Estado, sino en la coherente fidelidad al fundamento de la ley civil. La objeción de conciencia, de hecho, frente a una ley del Estado, atestigua el valor primario de la persona y de su justa libertad; es deber del Estado democrático el de no imponer una adhesión incondicional a las normas establecidas por la autoridad, sino el de dejar al ciudadano «la posibilidad de reflexionar libremente sobre la realidad legislativa del momento, y así preparar, llegado el caso, una eventual reforma de la legislación».

Siguiendo la nota pastoral, el ponente se centra en la objeción de conciencia ante el aborto, dejando aparcada la objeción de conciencia referente al servicio militar.

El mandamiento de no matar a un inocente obliga moralmente, de forma grave, a todos y siempre. La «cultura de la vida» representa la base, por así decirlo, material, de la objeción de conciencia, la cual, a su vez, encuentra su propia raíz, como se ha visto, en las mismas fuentes bíblicas, Tradición y en el «sentir y consentir» de todo el pueblo de Dios. 
En realidad, no existe valor más humano que el de la vida. Por ello, cuando la Iglesia interviene en defensa de la vida, desde la concepción a su muerte natural, la Iglesia no quiere introducir un Estado cristiano: «quiere simplemente promover un Estado humano. Un Estado que reconozca como su deber primario la defensa de los derechos fundamentales de la persona humana, especialmente de la más débil» (VE. n. 101).

Al juicio del ponente, las varias hipótesis de objeción de conciencia deducibles del EV., pueden reconducirse en conjunto a la categoría general de la objeción de conciencia en el campo bioético. Dentro de este campo, pueden especificarse los distintos casos en los que cabe plantear la objeción de conciencia: la objeción al aborto, a la eutanasia, a las manipulaciones genéticas, sobre todo, a las que conllevan el resultado letal del embrión, y, finalmente, las objeciones que pueden nacer en aquella rama de la bioética, que es definida procreativa; precisando que en este último caso sólo se atenta al principio del respeto de la vida humana, en modo directo e inmediato, cuando a las susodichas técnicas de fecundación artificial les acompaña la supresión de los embriones. Si así no fueran, el principio ético que viene en consideración no es el del derecho a la vida en sí, sino el principio, ciertamente importante, pero probablemente de menor obligación moral, de la dignidad y del significado unitivo del acto procreativo humano.

En cuanto al aborto, dada por supuesta la doctrina de la Iglesia, el ponente pone su acento, por una parte, en algunos particulares sujetos, a quienes se les debiera reconocer el derecho a la objeción y, por otra, en la individualización de las específicas fases, objeto de la objeción misma.

Junto a los sujetos, por así decirlo tradicionales y típicos, a saber, el personal médico y sanitario, se reclama la situación particular del juez tutelar que en el ejercicio de sus funciones deba autorizar el aborto del menor: La Corte constitucional italiana, con sentencia n. 196 del 1987, ha considerado infundada la cuestión de la legitimidad de la ley sobre la interrupción voluntaria del embarazo, en cuanto no se prevé la objeción de conciencia en dicha circunstancia. El Episcopado italiano, por su parte ha manifestado inmediatamente la necesidad de legitimar, también, este tipo de objeción.

Se recuerda la situación de los farmacéuticos en los países en los que está legalizada la venta de la así dicha píldora abortiva, la R.U. 486, en el caso que no estén a salvo, en el ejercicio de su profesión, por alguna cláusula de conciencia.

Respecto a los perfiles objetivos, la EV. pide que la objeción de conciencia sea tenida en cuenta en la fase consultiva, preparatoria y ejecutiva del procedimiento abortivo (n. 74). 
En este apartado el ponente quiere hacer constar que la objeción de conciencia no significa que el objetor deba abstenerse de ofrecer, en la fase consultiva, formas disuasorias del aborto en pro de la maternidad. A su juicio, es un deber para el médico objetor hacer uso de todas las posibilidades ofrecidas por la ley en pro de la vida, y una injusticia si la legislación civil no admitiera la intervención del médico objetor en esta función promocional en favor de la vida.

Siempre en referencia a estos perfiles objetivos, la objeción de conciencia debe tenerse presente también en las prácticas del diagnóstico prenatal, si están funcionalmente conexas al aborto (aborto selectivo). De igual forma, en las manipulaciones genéticas, a no ser que su objetivo sea estrictamente terapéutico. En particular, la hipótesis de la occisión del embrión fecundado in vitro, no implantado en el útero, pero capaz de vivir y aún de alojarse. Se trata de casos en los que, aun en la ausencia de una disposición, es legalmente, no sólo moralmente, lícito plantear la objeción de conciencia, por lo menos, en virtud de una extensión análoga de las normas referentes al aborto.

No parece que exija particulares reflexiones el tema de la objeción de conciencia frente a la eutanasia, en el supuesto de su legalización. Los mismos principios sobre el valor de la vida y sobre el sentido de la vida humana son aplicables en el caso.

En fin, el objetor, en los posibles casos descritos, debe estar a salvo tanto en el ámbito penal como en el plano legal, disciplinar, económico y profesional.

Queda un último problema: los principios éticos de las diversas formas de procreación asistida.

El lugar propio de la generación es el amor conyugal, consagrado por y en el matrimonio. En consecuencia, la fecundación heteróloga contrasta con la propiedad de la unidad del matrimonio, con la naturaleza propia de la familia, según la tradición hebrea-cristiana. De ahí, el deber de plantear la objeción de conciencia por parte del agente sanitario parece coherente, puntualizando que esta obligación no posee la misma entidad, en el ámbito moral, que la planteada respecto a la inviolabilidad de la vida.

Tocante a la fecundación homóloga, si bien no atenta a la unidad del matrimonio, queda la disociación del significado unitivo del acto conyugal con el procreativo, razón por la que, según la doctrina de la Iglesia, es moralmente ilícita.

Como conclusión de estas reflexiones, el ponente quiere recalcar que el derecho-deber de la objeción, sin más, no representa ciertamente la solución de los problemas que emergen en el campo de la bióetica. Representa un «no» que se impone como imperativo categórico a la concien- 
cia, «el límite infranqueable más allá del cual el hombre libre no puede pasar y, al mismo tiempo, indica el mínimo que debe respetar y del que debe partir, para pronunciar innumerables "síes"» (EV. n. 75).

8. Tras estas comunicaciones vino el espacio dedicado al debate. En realidad, el tiempo se agotó redundando en el temario expuesto. Se alude al veto del Presidente de USA, Sr. Clinton, a la ley del Parlamento, prohibiendo el aborto a las 20 semanas $^{5}$. Se explica el modo de proceder: se saca el feto del útero de la madre, se introduce una aguja en el cráneo, provocando la muerte instantánea. Lo espantoso del caso —manifiesta un doctor ginecólogo americano- es afirmar que esta intervención no deja secuelas en la madre, cuando, en realidad, produce una infección en la placenta, dejando a la madre afectada para siempre.

9. El segundo día del congreso se abrió con la conferencia de la prof. de la facultad de Derecho en la Universidad de Harvard, Doña Mary Ann Glendon: Identità della donna e diritto alla Vita.

La ponencia consta de cuatro apartados:

1. Tiempo de turbulencia.

Como hace tiempo recordaba S. Pablo a los Corintios, una ley que nunca puede ser revocada es la ley del cambio: «Pasa la apariencia de este mundo». Pero mientras el cambio es una constante, su ritmo es variable.

Nuestro tiempo se caracteriza por una transformación social tan rápida que, a menudo, nos sentimos desorientados Las estructuras intermedias de la sociedad civil, incluida la familia, parece que están en desorden. Criterios que han regulado durante mucho tiempo los comportamientos de hombres y mujeres están siendo cuestionados. Y, citando el n. 4 de la EV., destaca tres rasgos de este tiempo de cambios que nos ha tocado vivir, que los considera importantes para el tema de su conferencia:

1) Este tiempo de turbulencia ha dado lugar a una serie de situaciones sin precedentes en la historia.

2) Ha sido el período en que el feminismo moderno ha tomado forma de movimiento organizado.

3) Es sorprendente cómo muchos de los cambios más profundos y de los dilemas de nuestro tiempo han ido enlazados con una transformación de los roles de la mujer.

La ponente concreta más este último rasgo:

5 OR., 13 de abril, 1996, 2; Respuesta de la Conferencia Episcopal de USA, en OR., 19 de abril, 1996,4. 
a) La mujer, en los países desarrollados, ha hecho grandes avances en educación y trabajo. El cambio más dramático en ese campo ha sido que las madres de niños pequeños han entrado de una manera masiva en el mercado del trabajo remunerado. Mas hay que tener en cuenta que tan importante como lo que cambia es lo que no cambia: mientras el grupo tradicional de la sociedad que prestaba cuidados sin remuneración ha disminuido, la proporción de personas que no pueden valerse por sí mismas — niños, enfermos, incapacitados- permanece inalterable, y la sociedad no ha encontrado todavía solución a este problema.

b) El impacto del divorcio no es el mismo en el hombre que en la mujer. La relación divorcio-riesgo de pobreza es mayor en las mujeres que quedan con sus hijos, como cabezas de familia. Esto ha traído como consecuencia que las mujeres tienen menos hijos.

c) La vida de la mujer ha sido profundamente afectada por el debilitamiento de la conexión entre sexo y procreación. El aborto no sólo se ha hecho realmente admisible, sino que ha encontrado diversos grados de legitimación. La biotecnología ha transformado el proceso de la reproducción humana con contraceptivos hormonales, inseminación artificial y fecundación in vitro.

Estos cambios han tenido su reflejo en la legislación de las democracias liberales. A partir de 1960, leyes, que habían permanecido inalterables durante más de una centuria, han sufrido un cambio radical. El matrimonio, que era una institución, cuyo término legal era sólo por la muerte o por una causa grave, ha pasado a convertirse en un acuerdo, que puede deshacerse a instancia de uno de los cónyuges.

Una serie de leyes y programas se han estructurado de tal manera que el foco de su atención va dirigido al individuo más bien que a la familia como tal, con lo que se enfatiza la separación de los miembros de la familia, en lugar de promover su unión.

Las leyes han reducido ampliamente su desaprobación de las relaciones sexuales, fuera del matrimonio, entre adultos.

El aborto no sólo ha llegado a ser permitido en ciertas circunstancias, sino que en USA, por decisión judicial, ha sido elevado al rango de derecho constitucional de la mujer. En las recientes conferencias de la ONU en El Cairo (1994) y en Beijing (1995) se hicieron esfuerzos por lograr el reconocimiento del aborto como derecho universal humano.

A juicio de la ponente, como considera previsible que iniciativas legales de este tipo continúen a nivel nacional e internacional, le parece muy oportuno dedicar atención al problema de la enorme diferencia de sentido que dan a palabras como «derechos» $\mathrm{o}$ «libertad» quienes toman parte en los debates políticos. 
2. Los dos lenguajes de los Derechos.

Mary Ann habla de la experiencia que hemos tenido todos, cuando hemos comenzado a aprender un idioma distinto al nuestro. Nos encontramos con la agradable sorpresa de palabras afines a las de nuestro idioma. Pero, muy pronto, descubrimos lo que los franceses llaman «faux amis», falsos amigos, palabras que tienen el mismo sonido que las de nuestro idioma, mas tienen un significado completamente distinto.

La ponente traslada esta experiencia, a lo que sucede en los debates sobre los derechos humanos. Según ella, «la reciente conferencia de Beijing fue un ruidoso bazar, donde abundaron los malentendidos lingüísticos». Califica de siniestro «el caballo verbal de Troya, que vino a ser una especie de mantra para la conferencia de Beijing»: «Los derechos de la mujer son derechos humanos y los derechos humanos son derechos de la mujer». Este slogan es verdadero a medias. Los derechos humanos son derechos de la mujer y del hombre, basados en la dignidad humana, afirmación expresa en la Declaración Universal de los Derechos humanos de 1948. Pero la afirmación inversa que «los derechos de la mujer son derechos humanos» fue un intento de introducir como de contrabando en el elenco internacional de los derechos humanos varios «derechos reproductivos», que han sido reconocidos como derechos de la mujer en unos pocos Estados.

Lo que hay que poner de relieve aquí - dice- es que los debates más recientes sobre los derechos no versan simplemente sobre lo que debería reconocerse o no como derecho. En el fondo, versan sobre el sentido mismo de lo que es tener un derecho, sobre la estructura y sentido de la libertad, en particular, sobre la relación entre libertad y responsabilidad y verdad y, en última instancia, sobre la naturaleza de la persona humana.

Palabras como «derechos» 0 «libertad» tiene muy diferentes significados dentro de las dos principales formas del discurso político en el mundo actual. La ponente califica estos dos lenguajes con unos adjetivos que no tienen traducción literal al español: «libertariam language» y «dignitariam language», es decir, — parafraseamos nosotros- un lenguaje basado en un concepto de la libertad como ejercicio de una autodecisión sin restricciones e individualista y un lenguaje basado en la dignidad de la persona humana que exige la solidaridad con los demás.

Ya en el siglo XVIII podían advertirse divergencias en el horizonte común del pensamiento moderno sobre los derechos. La tradición política angloamericana ha promovido las libertades políticas y civiles, configurándolas como «derechos negativos», a saber, como una no intervención del Gobierno; mientras que los países más influidos por la tradición romano-germánica han hecho que esos derechos políticos y civiles vayan 
acompañados de ciertas obligaciones positivas por parte de los Estados respecto de los ciudadanos y por parte de los ciudadanos respecto unos de otros.

Esta diferencia se ha acentuado en nuestros días. El discurso sobre los derechos en los países de influencia anglo-americana concede la máxima prioridad a la libertad del individuo frente a las restricciones por parte del Gobierno. En estos sistemas se tiende a formular los derechos sin mencionar sus límites, su relación con las responsabilidades o con otros derechos. Es notable la ausencia de derechos (o deberes) económicos y sociales del tipo de los que se encuentran frecuentemente en las Constituciones de la Europa continental.

El discurso «dignitario» sobre los derechos, que encontramos en la Declaración Universal de los Derechos Humanos de 1948, en algunas Constituciones posteriores a la Segunda Guerra Mundial y en la doctrina social de la Iglesia católica se caracteriza por un tratamiento más matizado de la libertad y de la responsabilidad. Los derechos son vistos, no sólo como protegidos por unos procedimientos justos, sino también como dotados de una estructura normativa, basada en el respeto a la dignidad humana. Los derechos específicos se formulan de tal manera que queda clara la relación de unos con otros, que ciertos grupos tienen derechos como los individuos y que las entidades políticas tienen responsabilidad como los ciudadanos.

Así, incluso en documentos profanos, la libertad ligada a la dignidad del hombre («dignitariam freedon») apunta hacia la idea central acerca de la libertad humana expresada en la «Veritatis Splendor» y en la «Evangelium Vitae», a saber, que la auténtica libertad no puede estar desconectada de la verdad.

3. Derechos de la mujer y libertad auténtica.

El feminismo duro de los años 70 no ha conseguido la adhesión mayoritaria de las mujeres, ni en Estados Unidos, donde tienen influyentes portavoces.

Llama la atención, sobre todo, el que las mujeres jóvenes estén más alejadas del feminismo «oficial» que las mujeres mayores. Las encuestas americanas revelan que solamente una de cada cinco mujeres, que están estudiando, se considere feminista.

La razón principal, por la que las mujeres de hoy rechazan la etiqueta de «feminismo», según un reciente estudio, realizado por la historiadora Elizabeth Fox-Genovese, es que identifican ese término con un movimiento y con unas organizaciones, que son percibidas por ellas como indiferentes a sus preocupaciones más profundas.

Más en concreto: no lo admiten por la actitud negativa del feminismo oficial hacia el matrimonio y la maternidad, por su actitud antagónica 
respecto a los hombres, por su intolerancia a que se pueda disentir de su toma de posición en temas como el aborto o la homosexualidad.

Como dice el feminismo libertario extremista, no parece ilusorio esperar la aparición de un nuevo feminismo, que opte por la afirmación de la vida. Pero surge una pregunta: ¿Cuáles serían las señas de identidad de un feminismo que promoviera una civilización de vida, así como la libertad y la dignidad de la mujer?

La ponente sugiere cuatro notas que, en su opinión, debería tener ese nuevo feminismo:

a) Escuchar a las mujeres, como advierte Juan Pablo II, cuando hablen acerca de lo que es más importante para ellas y no decirles arrogantemente lo que deberían o no deberían pedir. Cuando Elizabeth FoxGenovese entrevistó a mujeres de toda clase social y de todas las edades, encontró un cuadro mucho más complejo que el pintado por el feminismo oficial. Descubrió que la mayoría de las mujeres, independientemente de que tuviesen o no hijos, sentían una relación especial con la vida. Descubrió, también, que la mayoría de las mujeres, que eran madres, tendían a considerar la maternidad como el hecho central de su vida.

Al mismo tiempo, sin embargo, se encontró con que la mayoría de las madres deseaban ejercitar al máximo los talentos que Dios les había dado en amplias esferas, como la económica, social, política y cultural.

b) Al tratar de los problemas de la mujer como problemas sociales de gran complejidad, parece prudente tener presente en la mente, como lo ha hecho el Santo Padre, la extensión limitada de nuestro conocimiento respecto a lo que es innato y lo que es cultural en el hombre.

La ponente hace mención de cinco posturas dogmáticas, que han arrojado más sombra que luz en los problemas de la mujer:

1) El «feminismo-igualdad», que insiste en que no hay diferencias significativas entre el hombre y la mujer;

2) $\mathrm{El}$ «feminismo-diferencia», que trata al hombre y a la mujer como si fuesen virtualmente especies diferentes;

3) El «feminismo-dominancia», que proclama la superioridad de la mujer;

4) El «feminismo-género», que considera al «macho»y a la «hembra» como meros constructos de la sociedad;

5) El determinismo biológico rígido, asociado con algunos críticos del feminismo, que desearían encerrar al hombre y a la mujer en los roles que tuvieron en una imaginaria edad de oro.

c) Un auténtico feminismo no debería ser excluyente, sino que debería tratar a hombres y mujeres como compañeros, como «partners» y no como antagonistas. 
d) Un feminismo que fuera de verdad afirmador de la vida debería ser una feminismo radical. Radical en el sentido de ir a la raíz de las cosas, radical en el sentido del Concilio Vaticano II, que expone con tanto calor la idea de que los órdenes político, social y económico deben extender sus beneficios de la cultura a todos y ayudar a los individuos, hombres y mujeres, a que desarrollen sus talentos de acuerdo con su dignidad innata.

4. Mujer y civilización de vida.

La ponente, remitiéndose a la Carta Apostólica sobre la Mujer de Juan Pablo II, en la que se afirma que la mujer tiene unas dotes especiales, un «genio femenino» que el mundo necesita más que nunca (n. 4), y, rememorando el pasado, en el que las mujeres han preservado la cultura de la vida, a pesar de las dificultades de todo tipo, manifiesta que, si hoy miramos a nuestro alrededor, veremos un coraje similar en las mujeres que están sacando adelante a la familia en condiciones de enormes dificultades e inseguridad. La generación actual de mujeres tiene su propia frontera: el territorio desconocido, creado por dos décadas de cambios drásticos en el comportamiento social y político.

Sin duda, el desafío es enorme. Como se dice en la EV. la opción de defender y promover la vida puede ser tan exigente que, en ocasiones, alcanza la cota del heroísmo (n. 11). Pero ¿no es parte del secreto del radiante influjo de Juan Pablo II en el mundo de hoy, el que hombres y mujeres $-\mathrm{y}$, sobre todo, gente joven- deseen ser llamados a hacer cosas difíciles?

Como Moisés en la antigüedad, el Papa nos recuerda que no debemos tener miedo «pues el Señor tu Dios va contigo; El no te dejará ni te abandonará» ${ }^{6}$.

10. Tras esta ponencia, se alzan algunas voces interpelando a la ponente sobre el modo de poder llegar al convencimiento de nuestra sociedad. La prof. Glendon manifiesta la necesidad de presentar nuestra verdad al mundo como un proyecto a realizar por la vía del diálogo, en el que se plasme la armonía entre la Fe y la Cultura. Se alude a la carta de los Derechos de Familia, redactada al margen de la fe, del matrimonio, no como sacramento, sino como patrimonio de la humanidad. Se echa en falta el desacuerdo respecto a elementos comunes, v.g. ¿qué es el hombre, qué es la mujer?, etc.

11. La sesión matinal quedó interrumpida por la audiencia del Santo Padre concedida a los congresistas. A la tarde, se dio lectura a las dos comunicaciones matinales programadas, postergando la siguiente ponencia y comunicación p.m. al sábado a.m.

6 OR., 26 de mayo 1996, 7. 
La primera comunicación, titulada «Diritto alla Vita e diritto all'ambiente» fue leída por el prof. de Filosofía de Derecho en la Universidad de Valencia, Jesús Ballesteros.

El prof. Ballesteros divide en tres apartados:

1. La conjura contra la vida.

Se hace alusión a la EV., en la que se señala las dos posiciones antagónicas que amenazan el derecho a la vida: «una libertad sin ley» y una «ley sin libertad» (n. 22). Ambas posturas vienen a coincidir en el miedo a la vida y al futuro al asumir las premisas malthusianas del crecimiento de la población en progresión geométrica y de los alimentos sólo en progresión aritmética.

2. El derecho al medio ambiente en la doctrina de la Iglesia y en las declaraciones internacionales.

a) Antropocentrismo:

El relator, frente al ecologismo radical, se remite a la EV., en la que se afirma el dominio sobre la totalidad de la naturaleza concedido por Dios al hombre (n. 42). Por ello, tanto en el Documento del Pontificio Consejo para la Familia publicado con ocasión de la Conferencia de El Cairo (Evoluciones demográficas. Dimensiones éticas y pastorales, 25.3.94), como en las anteriores Declaraciones de Estocolmo del 72 y Río del 92, se insiste que el titular único del derecho al medio ambiente es el ser humano. En esta línea tenemos, también, la Declaración del Consejo Económico y Social de Naciones Unidas de junio del 94.

La FAO, por su parte, con motivo de la conferencia de El Cairo, destacó la exigencia de un «desarrollo más antropocéntrico habida cuenta de que los planteamientos biocéntricos no responden a las expectativas y a los recursos de los agricultores de los países del Sur. Ello evidencia la conexión entre antropocentrismo y solidaridad con los pueblos del Sur.

b) El principio de duración y la reciprocidad de los derechos y deberes. Contra el instanteísmo.

Mas al mismo tiempo que se rechaza el reduccionismo biologista, la EV., recogiendo enseñanzas de la «Sollicitudo rei socialis» se opone con igual contundencia al utilitarismo y hedonismo (n. 42). Según el relator, las reflexiones de los teóricos del derecho ambiental coinciden con las enseñanzas de la Iglesia, en las que se afirma los efectos destructivos de la autarquía, al creer que el ejercicio de su voluntad libre carece de límites y en el hedonismo, responsable de la ruina ecológica por su reducción de la atención al instante presente. Y la dimensión fundamental constitutiva del derecho al medio ambiente es precisamente la dimensión de la temporalidad, ya que «si sólo se consideran las necesidades del presente, todo recurso podría ser agotado y destruido para la satisfacción de tales necesidades y la protección carecería de sentido». La protección de los 
derechos de las futuras generaciones es el fundamento de todo el derecho ambiental. Esta protección se señala en el principio 1 de la Declaración de Estocolmo, en el principio 2 de la Declaración de Río, en el punto 1 y 2 de la Declaración de La Laguna de 26.2.94. Por consiguiente, se prohíben los actos que pongan en peligro tal conservación o el patrimonio genético o el genoma humano. Esta sería la especial novedad del derecho al medio ambiente como derecho, su condición de derecho-deber, su conciencia de la insuficiencia de la dimensión de la pretensión, sin la correspondiente responsabilidad.

c) El principio de solidaridad y la responsabilidad diferenciada de los países del Norte.

El relator, citando diversos documentos del magisterio pontificio, como «Tertio Milennio Adveniente» (n. 13), «Sollicitudo rei socialis» (nn. 37 y 28) «Laborem exercens» (n. 2) y «Evangelium vitae» (n. 5) dice que el derecho al medio ambiente exige el principio de solidaridad planetaria. Este principio cuestiona el estilo de vida dominante hoy, basado en el individualismo, ya que resulta evidente que el individuo aislado se encuentra impotente para hacer frente a los desafíos ambientales.

La conciencia de esta solidaridad planetaria se recoge en la Carta de Río en su n. 7, donde se subraya la mayor responsabilidad de los países del Norte en relación con los del Sur en el mantenimiento del desarrollo duradero, debido a la presión mucho más elevada que su modelo de producción y consumo ejercita sobre el ambiente mundial. La principal causa de los desequilibrios ecológicos se debe al uso abusivo por parte del Norte de recursos no renovables e indispensables para la continuidad de la especie, así como la acumulación de armas capaces de destruir varias veces el planeta.

3. El derecho a la vida y el derecho al medio ambiente.

Frente a las dos actitudes amenazantes del derecho a la vida, la Doctrina social de la Iglesia y las Declaraciones Internacionales coinciden:

A) Considerar al ser humano como titular único de derechos, frente a los biologismos. Si bien este derecho aparece claramente unido al deber de cuidar de los recursos.

B) Defender a las futuras generaciones como titulares de derechos, frente a las tesis malthusiana, que reduciría los derechos a los titulares actuales del derecho de propiedad.

C) Subrayar la responsabilidad fundamental del Norte en la generación de los desastres ecológicos, debido a su mucha mayor presión sobre el ambiente.

La segunda comunicación del prof. Hugo Obiglio, miembro de la Pont. Academia para la Vida, Director del Instituto de Etica Biomédica 
de la Pont. Univ. Católica Argentina, lleva como título: «Sperimentazione sull'uomo e diritto».

El relator comienza la lectura de su disertación, manifestando que se impone romper la sinonimia con que habitualmente se manejan los términos de «experimentación»e «investigación».

La investigacion va encaminada a la búsqueda de un conocimiento de la realidad física, que obliga a mantener la verdad durante todos los pasos por los que atraviesa la investigación, desde el planteo del problema objeto del estudio, la realización de los experimentos y el subsiguiente análisis de los resultados.

Estos pasos deben ser dados por el científico en libertad y con responsabilidad. Su reconocimiento ratifica la moralidad o la eticidad hoy negada de la ciencia, puesto que «la moralidad de los actos está definida por la relación de la libertad del hombre con el bien auténtico» (SV. n. 4).

La experimentación, en cambio, citando a Claude Bernard es «el conjunto de artificios por los cuales el hombre de ciencia busca realizar una observación rigurosa de los hechos, que ocurren en condiciones mantenidas constantes».

Otra de las diabólicas paradojas que vive el mundo científico en la actualidad es el de, por un lado, reunirse con periodicidad para redactar manifiestos, declaraciones y códigos referentes a la experimentación humana y, por otro, leer en publicaciones científicas de primer nivel, trabajos de experimentación, cuyo factor dominante es el beneficio en el plano económico, relacionados con el aborto provocado de embriones de cinco meses, programados artificialmente con el fin de que la sustancia nigrans de su cerebro o el tejido fetal adrenal se inyecte a pacientes portadores de la enfermedad de Parkinson .

Con estas premisas, citando los nn. 20 y 23 de la EV., dice que para promocionarle a la dignidad humana un fundamento firme, es preciso concebir al hombre como «imago Dei», pues el único modo de entenderlo capaz de justificar su carácter de fin en sí mismo.

Desde esta óptica, al juicio del relator, es necesario enumerar los principios dominantes, que hay que tenerlos en cuenta, en toda investigación y experimentación: 1) el interés de la ciencia médica, 2) el interés individual, 3) el interés de la comunidad, el «bonum comune».

La naturaleza humana es la misma desde siempre. Sus principios y leyes debieran ser iguales para todo; sin embargo, los cambios culturales y el progreso científico que marcan nuestra vida moral parecen diluirse en estos tiempos. Se olvida que «no es lícito ni siquiera por razones gravísimas, hacer el mal para que produzca el bien», que ni siquiera la buena intención basta para justificar la bondad de una acción. 
En razón de esta confusión, el relator considera conveniente repetir los conceptos vertidos por el Papa Pío XII, cuando decía que en materia de moral médica debieran considerarse tres ideas básicas:

1) La moral médica debe basarse sobre el ser y la naturaleza. Y esto, porque ella debe responder a la esencia de la naturaleza humana, a sus leyes y relaciones inmanentes. He aquí por qué una moral médica puramente positivista se niega a sí misma.

2) La moral médica debe ser conforme a la recta razón, a la finalidad y ordenarse según los valores. La moral médica no vive en las cosas, sino en los hombres, en las personas, en los médicos, en su juicio, su personalidad, su concepción y realización de valores.

3) La moral médica debe enraizarse en lo trascendente. El deber moral no depende de la complacencia del hombre. La acción moral es su cometido. Este fenómeno obliga a reconocer que la moral médica posee en último análisis un fundamento y una regla trascendente (SS. Pío XII, Discurso a la 171 Asamblea de la Asociación Médica Mundial (30 septiembre 1954). En López Medrano).

Tras este recordatorio, el relator entra en el campo de la Bioética, y citando el magisterio de la iglesia (CC. art. 2.275; CDF, instr. «Donum vitae», 1,3), dice que «Algunos intentos de intervenir en el patrimonio cromosómico y genético no son terapéuticos, sino que miran a la producción de seres humanos, seleccionados en cuanto al sexo u otras cualidades prefijadas», manipulaciones contrarias a la dignidad pesonal del ser humano, a su integridad y a su identidad (CDF, instr. «Donum vitae»,1,6).

Termina su comunicación, manifestando que la situación en el mundo científico dista mucho de regirse por estos principios básicos, de una Etica Común. Primero, porque la investigación se complica cuando se practica sobre el hombre y, aún más, cuando se acerca a algo tan personal y distintivo del género humano como son la mente y la sexualidad. Segundo, porque las presiones económicas hacen olvidar muchas veces los principios de orden moral antes mencionados. Tercero, porque la tecnología derivada de la ciencia es una herrramienta de poder, no sólo económica, sino también política. Entramos así en una nueva disciplina: la de la Geopolítica de la Ciencia.

12. El prof. de Derecho Privado y Derecho Romano en la Universidad de Salzburg, Theo Mayer-Maly, versa su conferencia acerca del II Diritto alla Vita e la trasmissione della Vita nei diversi sistemi de esperienze giuridiche contemporanee».

Se trata de una extensa intervención en la que podemos distinguir tres partes: una introducción, en la que hace referencia a algunos textos legales internacionales y nacionales, en los que se proclama el derecho y 
la protección de la vida. Una exposición de la normativa legal acerca de ocho Estados europeos sobre temas concernientes a la vida, como aborto, biotécnica de la reproducción, transplante de órganos, eutanasia. Y unas consideraciones finales.

1) Introducción.

Al comienzo de esta centuria en todos los países civilizados existía una protección total a la vida, regulada por leyes ordinarias. En ningún lugar se permitía o toleraba el aborto, sino que estaba severamente castigado. El principio de derecho común «nasciturus pro iam nato habetur» tenía sus consecuencias jurídicas. En ninguna parte se admitía la eutanasia. El suicidio, en sí mismo, no era punible, pero sí lo era la ayuda para quitarse la vida.

Solamente en los textos recientes que garantizan los derechos fundamentales se menciona el derecho a la vida, los debidos, principalmente, al exterminio en masa de judíos y de personas incapacitadas.

Entre los documentos internacionales más importantes que garantizan la protección de la vida, cita: la Declaración Universal de los Derechos humanos, de 10 de diciembre de 1948, en su art. 3., afirmando que todo individuo tiene derecho a la vida, a la libertad y a la seguridad de su persona. El Convenio Europeo para la protección de los Derechos humanos y de las libertades fundamentales, de 4 de noviembre de 1950, en su art. 2, «en el que se dice "el derecho de toda persona a la vida está protegido por la ley"», estableciendo cuatro excepciones: a) Pena de muerte como ejecución de la sentencia de un tribunal, en el caso de que el delito esté castigado con esta pena por ley; b) Muerte como consecuencia del recurso a la fuerza absolutamente necesario para asegurar la defensa de cualquier persona contra la violencia ilegal; c) Muerte como consecuencia del recurso a la fuerza absolutamente necesaria para efectuar una detención legal o para impedir la evasión de una persona detenida legalmente; d) Muerte como consecuencia del recurso a la fuerza absolutamente necesaria para reprimir, de conformidad con la ley, una revuelta o una insurrección. El Pacto internacional de Derechos civiles y políticos, de 19 de diciembre de 1966, en su art. 6, calificando el derecho a la vida como inherente a la persona humana y garantiza su protección por la ley. Por otra parte, dice: «Nadie podrá ser privado de la vida arbitrariamente». Los párrafos siguientes del art. 6 de este Pacto se ocupan del genocidio, hoy llamado «purga étnica» y de la pena de muerte. Sobre este punto el ponente remarca que la actitud de la EV. es de completa reserva.

Solamente unos pocos Estados han incluido en sus Constituciones la protección del derecho a la vida, garantizada internacionalmente. Entre esos Estados están España, art. 15, en el que se establece que todos tie- 
nen derecho a la vida y a la integridad física y moral (CE. del 29 de diciembre de 1978) y Alemania, en cuya Ley Fundamental (Grundgesetz), n. 2 del art. 2 se lee: «Todos tienen derecho a la vida y a la integridad física», añadiendo a continuación: «Estos derechos sólo podrán ser coartados en virtud de ley».

2) Panorámica legislativa de diversos Estados.

El ponente expone sucintamente la legislación de diversos Estados sobre problemas relacionados con la vida: aborto, biotécnica de la reproducción, transplante de órganos, eutanasia.

Entre los Estados citados por el ponente (Alemania, Suiza, Austria, Hungría, Holanda, Bélgica, Italia y España) vamos a limitarnos a Alemania.

a) Aborto

La regulación del aborto en Alemania ha pasado por diversas fases. Hasta 1974 el aborto era punible. Con posterioridad la ley n. ${ }^{\circ} 5$ para la reforma de la legislación penal introdujo una «regulación de plazos» (Fristenregelung), que dejaba sin castigar un aborto llevado a cabo en las trece primeras semanas de gestación. En aquella ocasión, el Tribunal Constitucional no aprobó esa disposición, derogándola en su decisión del 25 de febrero de 1975, al considerar que violaba el art. 2 del Convenio Europeo para la protección de los Derechos Humanos y el art. 2 de la Ley Fundamental.

Por la Ley n. 15 de Reforma de la legislación penal, en 1976, el legislador adoptó el sistema de las «indicaciones». Con la Ley de Reforma de la ayuda a las gestantes y a la familia, de 21 de agosto de 1995 (Schwangeren und Familienhilfeänderungsgesetz) se ha introducido el sistema de plazos.

Resumiendo, podemos decir que en la actualidad el aborto no es punible en los casos siguientes:

a) Cuando se lleva a cabo por libre deseo de la madre, la cual deberá acreditar que se ha sometido al asesoramiento de un médico o de un centro de asesoría autorizado, siempre que el aborto se practique en los tres primeros meses del embarazo.

b) Cuando esté en peligro la vida de la gestante o haya peligro de graves perjuicios físicos o psíquicos para la madre.

c) La literatura jurídica admite también el supuesto de que lo previsto en el apartado anterior se dé en el «nasciturus». Pero la constitucionalidad de este supuesto es problemática.

b) Biotécnica de la reproducción

Los abusos de la llamada medicina de la procreación están previstos en la Ley de protección de embriones, de 13 de diciembre de 1990 (Embryonenschutzgesetz). Esta ley considera como embrión «un óvulo 
humano capaz de desarrollarse, ya fecundado, desde el momento de la cariogamia. Esta ley penaliza la venta de embriones, la determinación del sexo con ocasión de la inseminación, el cambio artificial de la información genética de una célula germinal humana y la clonación.

A juicio del ponente, esta ley ofrece una laguna respecto a una inequívoca reprobación de la inseminación heteróloga, así como a una prohibición estricta de la maternidad subrogada. Los tribunales tienden a calificar los contratos de maternidad subrogada como contrarios a las buenas costumbres, «contra bonos mores».

c) Transplante de órganos

Desde 1973 en Alemania se han discutido los problemas legales del posible transplante de órganos. En septiembre de 1978 el Gobierno Federal aprobó un borrador de Ley de transplante de órganos, pero ni éste ni otros sucesivos han llegado a convertirse en ley.

Uno de los problemas principales es el concepto de muerte. Durante veinte años, el factor decisivo para la mayoría ha sido la pérdida irreversible de la actividad cerebral y no el colapso total del corazón y de circulación. Esta postura se ha debilitado considerablemente por el embarazo de una mujer, que había sufrido la pérdida irreversible de la actividad cerebral.

El tan frecuentemente invocado «desarrollo actual de la ciencia» no conduce, por sí solo, a una decisión convincente. Las observaciones de las ciencias naturales deben ir acompañadas de evaluaciones responsables para detectar los peligros del abuso de los avances científicos.

d) La eutanasia

Como no se ha llegado a un resultado legislativo, es necesario guiarse por la jurisprudencia más preeminente.

Un caso concreto: por sentencia del 4 de julio de 1984, un médico fue absuelto por el Tribunal Federal de la acusación de omisión de asistencia debida. El médico se había encontrado con una persona, que aún estaba viva, después de un intento de suicidio y no le proporcionó un cuidado intensivo, con el que hubiera podido salvar la vida del paciente. El médico estuvo con él hasta que murió.

El Tribunal Federal sostuvo que un médico no debe acceder a los deseos del suicidio de un paciente. El argumento principal de la absolución fue que su decisión no podía calificarse como injustificable desde el punto de vista legal, porque había estado con el paciente hasta su muerte en una situación límite por respeto a la personalidad del difunto.

En 1986, la 56 reunión de los juristas alemanes discutió la cuestión de si existe un derecho a la propia muerte. En el ámbito de una eutanasia pasiva, que se ha extendido considerablemente por los avances de la medicina intensiva, se acentúa más enérgicamente la voluntad del paciente. 
3) Consideraciones finales

El ponente, tratando de resumir las impresiones que uno saca de las disposiciones de los Estados, manifiesta «simplemente que esas impresiones son sofocantes y pésimas».

Hacia mediados de los años setenta de nuestra centuria, los países más cultos y ricos de Europa han abandonado la protección de la vida del no nacido con una uniformidad casi fantasmal. Solamente algunos Estados la han mantenido. El número de Estados, que se han conformado con el sistema de las «indicaciones» para autorizar el aborto, ha sido pequeño. Han proliferado los intentos de introducir una indiferenciada «disolución de plazos»(Fristenlösungen). La relativización de la protección de la vida del no nacido ha sido pararela a la relativización de la vida de los enfermos incurables y de los moribundos. En relación con estos temas, no se ha tomado en serio el art. 2 del Convenio Europeo para la protección de los Derechos Humanos. Y esto hay que decirlo, también, del Tribunal Europeo de Derechos Humanos.

La protección de la vida que, a nivel interno, está garantizada por las Constituciones de algunos Estados, ha resultado ineficaz, más en Alemania que en España. En muchos Estados los Tribunales constitucionales han tenido que intervenir en el tema del aborto, desempeñando un papel lamentable. No era éste el caso de Alemania en un comienzo, pero la tendencia a nombrar los miembros de los Tribunales con criterios políticos, ha tenido consecuencias fatales para la problemática, que estamos tratando.

Es sorprendente - dice el ponente- cómo muchos incumplimientos del deber de protección de la vida han sido precedidos por una proclamación del respeto a la vida. Es extramadamente difícil encontrar las razones de estos incumplimientos. ¿Estamos ante un cambio colectivo de conciencia? ¿O nos encontramos con los resultados de una sutil campaña?

El ponente termina su intervención con una reflexión relacionada con el Estado del bienestar: los expertos nos dicen que nuestras pensiones y nuestro seguro de enfermedad no podrán financiarse en un futuro próximo, si no cambia la pirámide de población. Esto nos exige que dejemos de matar a los futuros contribuyentes. El día en que todos nos demos cuenta de esto, puede ser demasiado tarde.

13. Se da lectura a dos comunicaciones. La primera por el prof. Carl Anderson, Decano del Instituto Juan Pablo II para el Matrimonio y la Familia: Il diritto alla Vita nel sistema giuridico americano, y la segunda por el prof. Heinhard Steiger, Il diritto alla Vita nel sistema constituzionale tedesco. 
El prof. Anderson comienza con una advertencia preliminar: el «sistema» legal americano está compuesto por cincuenta sistemas correspondientes a los cincuenta Estados de la Unión y por un sistema nacional federal.

Hasta que el Tribunal Supremo de los Estados Unidos no determine con claridad la norma constitucional aplicable a una cuestión legal concreta, los distintos Estados frecuentemente desarrollan principios diferentes y, en ocasiones, antagónicos.

Por ejemplo, esa era la situación respecto al aborto y al derecho a la vida antes de la célebre decisión del Tribunal Supremo de los EE.UU. en 1973, en el caso Roe contra Wade. Con aquella decisión el Tribunal marcó una pauta nacional respecto a la legalidad del aborto. Hasta esa fecha los cincuenta Estados de la Unión mantenían una amplia variedad de enfoques en el tema del aborto. Treinta Estados permitían el aborto solamente para salvar la vida de la madre. Dos Estados permitían el aborto para salvar la vida o proteger la salud de la madre. Un Estado permitía el aborto para salvar la vida de la madre o cuando el embarazo era el resultado de una violación. Trece Estados permitían el aborto en las circunstancias señaladas en relación a la vida y salud de la madre, cuando el embarazo era consecuencia de una violación o incesto, o cuando el «nasciturus» tenía alguna anomalía. Cuatro Estados permitían el aborto sin ninguno de los requisitos anteriores, pero señalaban unos límites temporales, dentro del embarazo, para poder realizarlo.

Después de esta advertencia previa, el relator presenta una serie de casos concretos resueltos por diversos Tribunales, incluido el Tribunal Supremo de los EE.UU., que abarcan el aborto, muerte y donación de órganos, eutanasia, presentándonos el fondo doctrinal que, a su juicio, subyace en la resolución de todos estos casos.

Los Tribunales Federales, más que ver el derecho a la vida como fundamento del ejercicio de la libertad, ponen en primer plano el interés del individuo por la libertad, si bien limitado por el interés del Estado por proteger la vida. Dicho de otra manera: los Tribunales Federales han adoptado una creciente visión expansiva de la libertad, entendida ésta como autodeterminación autónoma, al mismo tiempo que van estrechando el alcance del derecho a la vida.

Así, el relativo esfuerzo del interés del Estado por proteger el derecho a la vida disminuye en la medida en que se deterioran las condiciones médicas o físicas de la persona. La lógica del análisis sugiere que, si el interés del Estado por la vida disminuye en la medida en que se deterioran las condiciones médicas y físicas de la persona, pocas razones existen para pensar que, de la misma manera, no disminuirá el interés del individuo por la vida. 
El peligro de esta Jurisprudencia de libertad radica en que el derecho a la vida solamente puede ser reconocido, en tanto en cuanto el individuo es capaz de autodeterminación autónoma. De esta forma, la capacidad para la autodeterminación autónoma se convierte en la medida para el reconocimiento del interés del individuo por la vida.

El relator concluye su intervención con estas palabras: «En los EE.UU. hoy, el derecho a la vida protegido por la Constitución está desvaneciéndose en aquellos mismos planos de la vida, en los que tradicionalmente el Derecho ha puesto especial cuidado en su protección».

El prof. Steiger comienza la lectura de su comunicación, manifestando que, a tenor de lo que se ha dicho en el Aula, debe modificar su texto. Según él, se han hecho críticas, que merecen respuesta. La Ley Fundamental, art. 2, pág. 1, establece que la dignidad del hombre es inviolable. El titular es el ser humano desde el momento de la fecundación. La Ley Fundamental establece la defensa del titular, la protección de la vida y la ayuda a mantenerla por parte del Estado. Afirma que el «nasciturus» tiene derecho a la vida, que no puede eliminarse por deseos de la madre y que el aborto es punible. Reconoce, no obstante que existen dificultades, v.g., la salud de la madre, en cuyo caso se requiere un certificado oficial médico para admitir el aborto. En cuanto al embrión, se le considera que tiene vida humana. Actualmente se tiende a la legalización de la intraimplantación. La esterilización no se permite. Repecto a la eutanasia, no es constitucionalmente admisible, si bien existe un debate abierto al respecto, en el que queda claro que no basta la voluntad del enfermo. En referencia al transplante de órganos, se impone antes cerciorarse de cuándo puede hablarse de muerte cerebral, sin deslegitimar el acuerdo del donante. En resumen - dice el relator- la situación es positiva, aunque existan zonas conflictuales y riesgos de dejar la vida a merced de terceros.

14. El prof. Giuseppe D'Alla Torre, Rector de la Libera Università Maria Ss.ma Assunta-Lumsa de Roma, presenta su ponencia titulada: «Le leggi contro la Vita: il loro significato politico-giuridico».

Resaltando la extensión de su ponencia, entregada a los congresistas como texto provisional, intentaremos, a nuestro leal saber y entender, resumirla.

El ponente plantea la cuestión bioética, cuya tema central es la tutela de la vida, como relevante en la peculiar prospectiva de las relaciones entre la Iglesia y comunidad. Como prueba de este aserto, se remite a las reacciones suscitadas tras la publicación de la encíclica «Evangelium vitae».

Subraya las profundas ambigüedades en el mundo del derecho en relación con la tutela de la vida. Ambigüedades a nivel nacional como pla- 
netario, tanto en la legislación como en su interpretación y aplicación administrativa y judicial. Pone como ejemplo, al respecto, la orientación del todo opuesta relevable por la jurisprudencia constitucional alemana e italiana, es decir, relativa a dos Estados con Constituciones bastante semejantes, teniendo un fuerte engarce iusnaturalista. De hecho, en una importante sentencia del Tribunal Constitucional Alemán, del 28 de mayo de 1993, se dice que entre los valores jurídicos protegidos por la Constitución no existe uno que tenga prevalencia sobre el resto, por lo que en el caso que deban contrastarse, debe prevalecer el criterio de una balanceada comparación. Precisamente en este sentido se había pronunciado el Tribunal Constitucional italiano en su sentencia n. 287/1975, al afirmar en su conclusión que «el interés constitucionalmente protegido relativo a la concepción puede colisionar con otros bienes, que gozan también de la tutela constitucional y que, en consecuencia, la ley no puede al primero dar prevalencia total y exclusiva, negando al segundo una adecuada protección». El Tribunal concluía afirmando que «no existe equivalencia entre el derecho no sólo a la vida, sino también a la salud de quien ya es persona, como la madre y la salvaguardia del embrión, que debe aún llegar a ser persona».

Desde este estado ambiguo que caracteriza la actual experiencia jurídica, a juicio del ponente, tres aspectos merecen indicarse:

Area de la juridicidad.

Por un lado, desde la sensibilidad por la protección de la vida a la creación de la categoría jurídica civilista, sobre todo, por la vía jurisprudencial, del daño biológico, entendido como lesión de la integridad psico-física de la persona. Tal integridad es, según la susodicha configuración, un bien protegido en sí y por sí, en relación al derecho a la salud, que generalmente goza de protección constitucional, prescindiendo de la capacidad laboral o beneficial del perjudicado.

Es evidente la relevancia del reconocimiento jurídico del daño biológico, respecto a la tutela de la vida en una prospectiva personalista. Si bien - manifiesta el ponente - las consecuencias de esta adquisición no han sido siempre coherentes. Así, la jurisprudencia italiana reconoce el daño biológico del concebido y, al mismo tiempo, reconoce el daño biológico sufrido por la madre por la intervención abortiva efectuada «ex lege», pero clínicamente no conseguida, dando lugar al nacimiento.

Por otro lado, en el sentido de la des-legislación de sectores relevantes en el mundo de la bioética. Este fenómeno tiene muchas caras: puede ser el resultado de la no intervención del legislador (en materia de la reproducción artificial de la vida); o de la elección del legislador de despenalizar una determinada materia, sin que sea sustituida esta despenalización por un sistema sancionador civil y administrativo eficaz (es el caso 
de muchas legislaciones sobre el aborto); o, aun, la opción legislativa por un «derecho débil», meramente procedimental, que no hace elecciones valorativas y no toma posición entre los intereses en conflicto (es lo que sucede en diversas legislaciones sobre las prácticas de fecundación artificial). Piénsese, también, en los casos en los que la intervención del legislador es sustituida por otros sujetos, como un Colegio profesional, cuyos códigos deontológicos pueden leerse como signo del retroceso de la juridicidad, ofreciendo una tutela débil e indirecta y, de todas formas, ausente, en el caso, de la intervención de un tercero respecto a los intereses en conflicto.

Area de los sujetos protegidos.

Los debates bioéticos y biojurídicos han abierto la discusión sobre la subjetividad jurídica en referencia a la vida humana. El problema se ha puesto, partiendo de la biología y de la genética acerca del comienzo de la vida humana, así como, en el plano filosófico, respecto al concepto de persona humana. En el mundo del derecho el problema se ha desarrollado en torno al concepto de la subjetividad jurídica, con referencia específica al nacimiento de la titularidad del derecho a la vida.

El ponente manifiesta que dichos debates han tenido el mérito de cuestionar el aborto. De hecho, ante el uso de las técnicas de reproducción artificial, ante el problema de los «embriones supranumerarios», a la licitud o no de la experimentación no terapéutica sobre los embriones humanos o a la producción de los mismos para uso comercial, se nota una convergencia acerca de la necesidad de establecer legislativamente un «estatuto del embrión», que establezca los confines y límites.

Esta toma de conciencia conlleva a la cuestión del aborto. Prescindir del aborto, equivaldría a aceptar un tratamiento diverso, en cuanto a la tutela jurídica, entre individuos humanos originados artificialmente e individuos originados naturalmente, con la ventaja que los primeros serían los protegidos, y con la clara contradicción del principio de igualdad, sin distinción por razones personales y sociales.

Consideraciones análogas pueden hacerse respecto al fin de la vida, como revela ejemplarmente la experiencia holandesa. La ley del 30 de noviembre de 1993 basa la despenalización de la eutanasia en el hecho que la intervención activa del médico venga previa solicitud expresa del paciente; la praxis refleja que la distinción fundamental entre interrupción «voluntaria» e interrupción «involuntaria» va perdiendo significado. Esto indica, por un lado, que la esfera jurídica subjetiva tiende a alargarse, pues se transfieren al paciente atribuciones que corresponden al médico; por otro lado, dicha esfera viene reducida, llegando a un desdoblamiento entre individuo y persona, en la medida en que se transfiere al médico el derecho de la vida o de la muerte. 
Area de la relación médico-paciente.

Según el ponente la experiencia jurídica camina desde una medicina paternalista de tradición occidental hacia una medicina contractual. La legislación y, sobre todo, la jurisprudencia tienden cada vez más a la afirmación del principio de autonomía en la relación médico-paciente, delineando, en consecuencia, configuraciones jurídicas en torno al concepto de los derechos -inviolables- del enfermo, más que en torno al bien del propio enfermo. Y, a un tiempo, la misma experiencia jurídica manifiesta, cada vez más, orientaciones de signo opuesto: el incremento sin límites del poder del médico.

A veces el fenómeno puede reconducirse hacia un burdo y banal efecto de vuelta atrás a la medicina paternalista. Se piense sólo en la experiencia norteamericana más avanzada y significativa referente al tema del consentimiento notificado por el acta médica, donde la obligación - $\mathrm{O}$ por lo menos la praxis - de la manifestación de la voluntad dada por escrito, se ha convertido, poco a poco, de ser un instrumento tutelar del paciente a ser un instrumento tutelar (civil o penal) del médico.

El fenómeno en cuestión, por otra parte, es fruto de una más profunda ambigüedad, a causa de la cual la experiencia jurídica conduce sustancialmente hacia una meta del todo opuesta a la que sustancialmente se persigue. Caso típico es el holandés sobre la eutanasia, en el que la legislación termina por incrementar el poder del médico en detrimento de la así dicha «reapropiación» de sí por parte del paciente, que es típica de una medicina contractual. De forma que se ha podido afirmar con sutil ironía, que «después de todo, la eutanasia es el último paso en el intervencionismo médico: el sufrimiento se alivia con cualquier medio, incluso, si este medio conlleva la muerte del paciente.

En conclusión, se puede observar cómo las contradicciones que marcan, en la edad contemporánea, la experiencia jurídica en el tema de la tutela de la vida, sean fruto del vuelco de una relación: del primado del derecho sobre la política al primado de la política sobre el derecho, cuyo efecto ha sido reducir el derecho a una mera realidad formal, extremadamente mutable y no coherente en la complejidad de sus imperativos. En otras palabras, el derecho ha llegado a ser instrumento autoritario de la imposición de la voluntad del más fuerte. Este dato, paradójicamente, se hace más evidente en las democracias, en donde la voluble voluntad de las variables mayorías enriquece el ordenamiento de normas contradictorias, que encuentran su razón, no en la lógica del derecho, sino en la voluntad dominante que se forma, de vez en cuando, sobre una específica cuestión.

Las leyes contra la vida y el sentido de la política.

El ponente se detiene en el concepto del bien común como fin último de la vida social. El bien común exige que la persona sea tratada como 
fin, no como medio. En consecuencia, demanda la vida de cada individuo y está orientado preliminarmente a su tutela. Cada vez que la ley dispone o permite la violación de la vida de un inocente, se niega este bien.

A la luz de la concepción clásica, en la medida que el principio de la indisponibilidad de la vida es empequeñecido en el ordenamiento positivo, la política misma se ve privada de sentido.

El ponente, consciente de la pluralidad de concepciones políticas, considera posible abrir una vía común entre las mismas, cuyo punto de engarce es el hecho del reconocimiento de los derechos humanos. Se trata de derechos preexistentes al ordenamiento jurídico positivo, que, en consecuencia, reconoce, no atribuye; inmutables en el tiempo e históricamente determinantes en el terreno del «ius positivum».

El ponente, dejando el debate sobre el fundamento, en cuanto está fuera de lo que se le ha encomendado, manifiesta que los derechos humanos, en la sociedad post-moderna, representan el nuevo rostro de la laicidad del Estado. Si, de hecho, laicidad del Estado es una expresión para indicar la existencia de unos límites al poder, dimensiones de una realidad, sustraídas a la soberanía temporal, desacralización de la política, los derechos humanos están fuera del orden de la política y, a un tiempo, la delimitan. Por consiguiente, en el caso de unas leyes contra la vida, la política invade un campo que no es el suyo.

Desde el punto de vista de la historia del pensamiento político y jurídico — dice el ponente- es interesante advertir que el eclipse del concepto del bien común ha sido allanado y acelerado por la doctrina de los derechos humanos, en la medida en que el fin social, objeto de la política, ha sido individualizado en la garantía de los derechos del individuo, considerado exclusivamente en sí. Mas también es interesante recordar el reciente magisterio social de la Iglesia, superando las posiciones recíprocamente excluyentes, en la medida en que los derechos humanos son considerados como contenido principal del bien común y deber propio de la actividad política.

La leyes contra la vida y el sentido del derecho.

El ponente nos habla de la doble tentación, en la que puede caer el Estado. Una, servirse del derecho positivo para imponer una ética. La otra, traducir en normas la praxis social inspirada en ciertos principios éticos, con la consecuencia de que, a través del derecho positivo, se impone una ética a las otras. Sin decir después, en relación con esta segunda tentación, de la contradicción ínsita al querer remitir los juicios de valor ético al principio de la mayoría.

Se subraya, por una parte, que el pluralismo ético cae en un círculo vicioso, del que parece imposible salir sin contradicciones. De hecho, si el legislador hace propia una ética entre tantas, viola el principio de la 
laicidad; si en nombre de este principio se abstiene, deja el campo libre a los conflictos y al más fuerte. Por otra parte, el «politeísmo ético» hace imposible, en la práctica biomédica, tomar una decisión en base a unos principios éticos compartidos. De esta situación contradictoria nacen las objeciones de conciencia.

Ha habido tentativas de salir de este círculo vicioso. Una es la así llamada «derecho débil», que consiste en un contenido meramente reglamentario por parte del Legislador, que, si bien no se niega su fuerza sugestiva, es incapaz de resolver los conflictos que surgen en el cuerpo social, como se señala en la EV.

Paradigmático resulta el «derecho débil» en el caso de la fecundación heteróloga. Se puede regular la acumulación del semen, su selección, su control por evitar las enfermedades, su idónea conservación en los bancos del semen, la modalidad del seguimiento en las prácticas de fecundación. Pero jamás podrá resolver los conflictos que nacen del interés del donador del semen al anonimato y el del concebido por conocer su paternidad; el interés de la mujer célibe por tener un hijo a través de la fecundación artificial y el interés del hijo por tener un padre; el interés del marido de la mujer fecundada con semen de un donador a desconocer la paternidad y el interés del así procreado a ver reconocidas las responsabilidades genitoras del hombre.

De lo que precede se evidencia cómo el problema de la laicidad del Estado viene a ser substancialmente el problema de la laicidad del derecho. Y, además, se demuestra la imposibilidad de un derecho laico, entendiendo con esta expresión un derecho neutral frente a las diversas tablas de valores éticos profesadas en el cuerpo social.

A juicio del ponente, en el positivismo jurídico se encuentra, probablemente, la raíz del problema y de todos los equívocos que se derivan. Si la temática de los derechos humanos pone en evidencia la subordinación del derecho positivo a un modelo jurídico superior, a cuya luz valoramos la legitimidad, ¿no cabe interrogarse si el problema de las opciones éticas del derecho no deba considerarse a la luz de la susodicha relación?

El problema no está, por lo tanto, si el derecho debe elegir una entre las tantas tablas de valores éticos, sino en ver cuál sea la especificidad estructural del derecho, es decir, la individualización de lo que le es «proprium» en el plano del «deber ser».

El derecho es instrumento de comunicación universal entre los hombres, es el ser estructura de convivencia y paz. Por decirlo así, su «ética» está caracterizada por algunos principios basilares, cuales son el recíproco reconocimiento de la dignidad del ser humano, la simetría de las posiciones y, por tanto, la reciprocidad de los derechos y deberes, el criterio de justicia en las definiciones de las relaciones intersubjetivas. 
Todo esto tiene gran peso de consecuencias significativas en el campo bioético: aborto, eutanasia, etc.

La agonía del derecho agnóstico y el rol de la Iglesia.

Según el «derecho agnóstico», fruto de la ideología liberal-radical, fundada en el agnosticismo religioso y el relativismo moral, la racionalidad de las leyes se da sólo por las decisiones de las mayorías; de la capacidad del legislador de emanar una norma capaz de salvaguardar una pluralidad de éticas y, por lo tanto, de praxis jurídicamente legítimas.

Según el ponente, este derecho ha llevado a la crisis del mismo derecho, evidente a los ojos de todos. Se impone la recuperación de la concienciación de la verdad del hombre, de los valores morales objetivos, de los derechos inalienables de la persona como derechos inscritos en un orden jurídico igual siempre para todos.

En esta dinámica se debe restituir a la religión el rol público que a la misma le compete.

15. Las voces que se oyeron tras la conferencia no hicieron más que remarcar lo ya dicho en referencia a la tutela del embrión, resaltando que en este terreno subyace lo económico en detrimento del sanitario. Se hace alusión a la Ley italiana de 1994 que, en el caso de intereses en conflicto, prevalece la salud de la madre, de ahí el homicidio voluntario, y a la Ley holandesa, diciembre de 1994, que posibilita la muerte del inconsciente por el médico, sin que se comunique estas occisiones. Se afirma la imposibilidad de solucionar la situación reinante, si nos mantenemos en el ordenamiento jurídico positivo. Urge ir a los principios universales, como indica el Santo Padre, remarcando que la política debe ser en interés de todos e instando al poder ejecutivo a quien compete dar las soluciones.

16. Se presenta dos comunicaciones. Una, titulada «Le leggi contra la Vita: analisi etico-culturale» por el prof. de Etica en la «Katolichi Universytet Lubelski-Polonia, Tadeusz Styczén. La otra, por el prof. de Filosofía de Derecho en la Universidad de Granada, Andrés Ollero, titulada: «Convinzioni personali e attività legislativa».

El prof. Styczén comienza su relación, aludiendo al título de su comunicación: «Las leyes contra la vida son de hecho una "contraditio in adiecto", pues la razón del ser del derecho es la tutela del bien del hombre, que exige ante todo - como suya una "conditio sine qua non"- la tutela del bien fundamental, que es la vida».

Para el relator tales leyes falsifican el sentido esencial de la ley, el mismo Estado como sujeto legislativo viola el principio de la justicia, por lo tanto, se autosuicida como Estado de derecho. La primera víctima de la violencia infligida en nombre de la ley y del Estado no es 
quien la sufre, sino aquel que lo inflige. De este modo cualquier forma de participación en un acto de un Estado de quitar la vida de seres inocentes, significa para cada uno de los que participan un acto de muerte moral suicida.

En esta situación, un análisis ético-cultural de las «leyes contra la vida» se reduce a desenmascarar de hecho tales leyes como un acto de actuación del absurdo de la «cultura de la muerte», con el objetivo de oponerse al proceso de la muerte de la cultura.

Con esto se diseña la finalidad de un análisis «ético-cultural»y su método.

El estudioso de ética llegará a este fin cuando 1) demostrará la validez universal de la afirmación: toda acción que realiza un absurdo es para el hombre, como ser racional y libre, absolutamente inadmisible y moralmente fatal y 2) (cuando) demostrará la validez objetiva de la afirmación: tal absurdo se hace real todas las veces que el hombre, como ciudadano de su Estado, participa en «una conjura contra la vida», participando junto al Estado en sustraer la tutela jurídico-legal a los seres humanos inocentes.

El ponente recuerda cómo en la Conferencia de El Cairo se ha intentado desenmascarar esta conjura de la vida y que no debemos olvidar Auschwitz. El estudioso de ética ante estos hechos debe cuestionarse en pro de una terapia. Según el relator se dan tres especies terapéuticas:

1) A los que no han aceptado, porque no han entendido, la terapia de despertar mediante la instrucción: el recurso a la información del lenguaje ético.

2) A los que han comprendido, pero no han aceptado, la terapia de la movilización: el recurso a la función parenética del lenguaje ético.

3) A los que no han querido comprender, la terapia, la más simple y la más difícil: volver a andar a las fuentes de la antropología y de la ética, y a la luz de ésas volver a ver la propia visión de la libertad.

En el primer caso sugerirá la pregunta si han tomado en consideración todos los posibles destinatarios de la fórmula «aborto seguro»; en el segundo caso, se añade a la información el momento de la parénesis: «Salva la víctima para salvarte a ti mismo»; en el tercero, el de confrontar la libertad en la prospectiva de su acto con la libertad con la que se revela como poder de negar lo que él mismo ha constatado.

Termina su relación, diciendo que el estudioso de ética, que sigue las huellas de Sócrates, advierte haber agotado la posibilidad de la palabra. Falta, sin embargo, el acto: el testimonio, un argumento ético por excelencia. Por eso K. Wojtyva dice en boca de Estalisnao, obispo de Gracovia: «La Parola non ha convertido, sarà il Sangue a convertire». 
El prof. Ollero, que en la actualidad es Miembro del Congreso de los Diputados en España, entra en la temática, señalando que la actividad política invita a privatizar las propias convicciones, bien para dejar campo libre a los no convencidos de nada, bien para estimular el ocultamiento de las auténticas razones de las propias respuestas políticas.

Es evidente - dice- que la democracia moderna, enraizada históricamente en planteamientos iusnaturalistas, se aposenta en el relativismo ético, con su afán de vincular a mecanismos formales la garantía de las expectativas de los ciudadanos, evitando depender de la mayor o menor exigencia ética personal de los gobernantes de turno.

Sorprendentemente, sin embargo, se insiste hoy en imponer al ciudadano, y muy especial al hombre público, un artificioso imperativo categórico, que le vedaría acudir a sus propias convicciones a la hora de abordar problemas de inevitable repercusión social.

Las razones en que pretende apoyarse tal propuesta son variadas. Se traza, por ejemplo, un abismo entre ética pública y ética privada, que obligaría a buscar en fuentes distintas de la propia conciencia los criterios decisivos. Se propone, incluso, una obligada neutralidad, que llevaría a abstenerse de tomar partido ante cualquier problema de especial relevancia ética.

Surge de inmediato la duda de si los formuladores llegan a ser conscientes del alcance de su propuesta de «privatizar» la solución de los problemas que — por razones éticas — se muestran más sometidos a la polémica.

A poco que se reflexione brota una doble perplejidad. Una, desde una perspectiva antropológica, una actitud individualista capaz de establecer a priori que el hecho de que una cuestión suscite, por razones éticas, una mayor polémica en el ámbito público, no implica que nos encontremos ante problemas sociales de particular gravedad. Otra, desde una perspectiva jurídica, pues cuando se insta a reducir al mínimo los supuestos respaldados por una sanción penal, es para reservarla a conductas que por su mayor calado ético producen particular agravio social.

De todo ello se deduce la insensatez de inhibirse por parte del responsable público o de proponer que tales acciones queden al privado arbitrio de cada ciudadano a la hora de tipificar conductas como punibles o a la hora de esclarecer las fronteras, cuya transgresión darían paso a una vulneración inconstitucional.

Para hacer justicia, se procura garantizar la imparcialidad. Igualmente para garantizar el respeto de los derechos humanos se tiende a huir de fórmulas de democracia directa, para depositar en los parlamentarios la obligada toma de conciencia de la situación. ¿De dónde puede obtener el parlamentario los criterios decisivos para su actuación? 
El relator afirma la complejidad que conlleva la representatividad. Considera que un parlamentario no puede neutralizar sus propias convicciones, facilitando al ciudadano - en la medida en que el sistema electoral lo haga posible- la adhesión o la repulsa de la conducta que de él coherentemente podría esperar. Esta exigencia de una actitud no inhibida parece traslucirse en el rechazo popular al sistema electoral de listas «cerradas» y «bloqueadas». El ciudadano se siente más satisfecho ante una representante personalizado, cuyas convicciones y coherencia de conducta está en condiciones de controlar, que ante una lista en la que se le exige deposite su confianza sin mayores matices. En este sistema electoral personalizado el parlamentario - aun al margen de todo mandato imperativo- está obligado a transparentar tanto sus propias convicciones como el grado de compromiso con ellas que asume en su actuación pública.

En el contexto actual de listas «cerradas» y «bloqueadas» pieza decisiva del «político indirecto» son los partidos políticos, cuyos programas electorales priman sobre las convicciones personales del parlamentario.

La progresiva pérdida de carga ideológica de los programas electorales tiende a convertir en decisiva la actitud de un sector del electorado, tópicamente calificado como «de centro». En tal ambiente encuentran fácil acogida recetas simplistas del tipo «no cabe imponer las propias convicciones a los demás» o «releguemos a lo privado cuestiones que tienden a romper el consenso social», dato que se revela en la política española respecto a los problemas relacionados con el derecho a la vida, que han ido perdiendo paulatinamente presencia en las ofertas programáticas de los partidos.

Es obvio - continúa- que el grado de vinculación ética de los programas electorales puede ser objeto de muy diversa valoración. Mas prescindiendo de tan importante matiz, la disciplina de voto acaba primando sobre los compromisos programáticos, por lo que el juego de las convicciones personales se verá remitido al grado de democracia interna, que en el caso español parece configurarse de manera particularmente vertical; descienden hacia las bases los dictados de la cúspide, que ausculta -más ahora entre los electores potenciales que entre los militantes- los oportunos cambios.

En esta tesitura se convierten en decisivos los medios de comunicación y los grupos públicamente activos.

Todo esto invita a profundizar en el auténtico dilema latente a la hora de abordar la presencia pública de las convicciones personales.

La democracia se apoya en el respeto a unos derechos humanos caracterizados como fundamentales, por lo que, en cuanto fundamentales, el respeto a tales derechos prima sobre el principio de la mayorías. Si así no fuera, estaríamos contabilizando una empírica «voluntad de todos», 
con decidida renuncia a elevarnos a una «voluntad general» de dimensión racional.

El malentendido de la doble racionalidad (razón y voluntad) lleva a presentar toda propuesta pública de exigencias objetivas como el intento de imponer, por imperativos sobrenaturales, una ética «contra-natura»; cuando la paradójica realidad es que quienes tal sugieren están negando en teoría la existencia de «naturaleza» alguna susceptible de transgresión.

¿Existe realmente una doble fuente de exigencias éticas en el ámbito público, derivadas del sistema democrático en un caso y del magisterio eclesiástico en el otro?

Para quienes responden afirmativamente al interrogante, tiene sentido hablar de intromisiones por parte del magisterio eclesiástico. Este pensamiento se sustenta en que «en ningún ámbito de la vida de la ley civil puede sustituir a la conciencia ni dictar normas que excedan la propia competencia».

La primera parte - manifiesta el relator - es difícilmente discutible. Problema distinto es qué ocurrirá cuando el rechazo moral de una ley se haga masivo, supuesto que los mismos teóricos del positivismo jurídico la admiten. En este caso, bien se admite la objeción de conciencia o, cerrada esta vía, el recurso a la desobediencia civil que — como hoy ilustran los «insumisos»- implica la asunción de las sanciones correspondientes a la infracción de la ley.

Para el relator el presunto dualismo planteado se diluye en la medida en que se produce una coincidente remisión a una realidad susceptible de servir de denominador común. El magisterio eclesiástico sobre cuestiones sociales no intenta tanto servir de vehículo a una normativa divinopositiva como garantizar el esclarecimiento de una realidad jurídico-natural. A su vez, los textos constitucionales que aspiran a la garantía práctica de los derechos fundamentales remiten también - a través de fórmulas como las de «contenido esencial», bienes jurídicos protegidos, etc. - a una realidad metapositiva.

Por ello, rebrota la evidencia de la imposible «neutralidad» de cualquier transferencia de debate a la esfera de la autonomía individual.

Conductas que - por los bienes jurídicos en juego y el reproche social que merecen- justifican la entrada en juego de la sanción penal, y no pueden quedar a la libre iniciativa de los ciudadanos, de modo que éstos puedan decidir, ateniéndose sólo a su propia conciencia. Los titulares de los poderes públicos no podrán eludir las responsabilidades que éstos llevan consigo.

Tampoco cabe apelar a la tolerancia para reconocer a algunos ciudadanos derecho a discrepar. Por definición, tolerar es dejar pasar una 
conducta que merece desaprobación. Pero sobre lo digno de desaprobación resulta difícilmente concebible fundamentar un derecho estable. Hablar de derechos supone abandonar el ámbito de lo tolerable para adentrarse en lo decididamente digno de protección.

Termina su comunicación, diciéndonos que si la democracia, en su sentido más pleno, es siempre una tarea para hacer, vinculada a garantizar los derechos fundamentales de los ciudadanos, es necesario asumir los ámbitos de responsabilidad que su papel político les reserve, aportando en su apoyo el máximo consenso social. Ello exige aportar las propias convicciones y llegar a un diálogo que enriquezca las instituciones democráticas, liberándolas de degenerar en el mero decorado de decisiones, faltas de transparencia y de razonada justificación.

17. El prof. de Filosofía del Derecho en la Universidades de Roma Toro Vergata y Pontificia Universidad Lateranense, Francesco D'Agostino presenta su ponencia titulada «La Teologia del Diritto Positivo: Annuncio Cristiano e Verità del Diritto».

El ponente da inicio a su disertación, manifestando la tentación de reducir el discurso teológico al derecho natural. El derecho natural se mueve todo él dentro de un horizonte ontológico y no teológico, como se hace patente en el hecho de que el debilitamiento de la ontología ha correspondido, en el pensamiento contemporáneo, un correlativo debilitamiento del iusnaturalismo. A veces, los iusnaturalistas han pensado que un buen puntal teológico puede ser útil para reforzar el fundamento de su doctrina. Pero no corresponde a la teología socorrer a las buenas razones del derecho natural: el bien se basta a sí mismo para defenderse y reafirmarse. El puntal teológico, en lugar de reforzarlo, lo debilita, obscureciendo su específico fundamento antropológico. El objetivo de la teología es el de ofrecer al derecho positivo un horizonte de sentido. ¿Bajo qué condiciones?

Una vertiente, en la que se sustancia el anuncio de la EV., es la llamada «a la continuidad con la tradición de la Iglesia» por corroborar la fuerte y cualificante afirmación de una necesaria conformidad de la ley civil con la ley moral. La denuncia de que carecen de valor jurídico todas las leyes que permiten o favorecen el aborto o la eutanasia, parece, en este contexto, no sólo como una deducción lógica operada a partir de una premisa, sino como memoria de una actitud y de un conocimiento que se revelan constantes en el Occidente. Análogamente, la fuerte recomendación a los responsables de la vida pública para que tomen decisiones valientes en favor de la vida (n. 90).

Desde esta luz, la valoración de la llamada a la fidelidad a aquel modelo de compromiso político, fundado en la diaconía, es una consecuencia específica del anuncio cristiano. 
Otra vertiente es la bíblica. La imagen bíblica del hombre que viene presentada por la EV., posee un intrínseco y exigente significado, que puede articularse en tres puntos esenciales, que corresponden a tres momentos esenciales del Kerigma evangélico. El primero es que el hombre es creado a imagen y semejanza de Dios, de lo que se desprende la sacralidad de la vida. El segundo es que el hombre es creado, en Adán, miembro de una única familia humana, por lo que la igualdad fraterna entre los hombres goza de un primado frente a toda posible diferencia e impone como principal virtud social la de la compasión y la de la solidaridad. El tercero, en cuanto así querido y así creado por Dios, el hombre tiene el don de la razón que — si bien en los límites de la creaturalidad- está capacitado de conocer la realidad, según verdad.

La sustancia de este anuncio es ciertamente un anuncio teológico; mas, a un tiempo, no es dogmático: no pretende un asentimiento prejudicial o irracional. Es un anuncio que llama - por usar el lenguaje de la EV.- a «una ley natural inscrita en el corazón del hombre» (n. 70).

El primer desafío de la EV. es en referencia al relativismo ético (n. 70). Este desafío nos lleva a la encíclica «Veritatis Splendor», que anuncia la capacidad del hombre de hablar según verdad y en la verdad.

Este anuncio es auténticamente teológico: nos invita a tener fe en la palabra de Dios, que nos asegura que el orden del mundo no es arbitrario, ni gobernado por fuerzas ciegas y obscuras; que el hombre en su operar en el mundo, es capaz de querer y de sustraerse a la omnipresente tentación de ceder a la ciega (y, por tanto, violenta) neutralidad del caso.

El segundo desafío concierne la democracia. El anuncio de la EV. es, al respecto, particularmente acentuado: o la democracia se funda sobre la explícita asunción de la dignidad humana y del bien común o es una palabra vacía (n. 70). Una democracia que relativiza todos los valores, que se limita a formular expresamente las «reglas de juego», deberá decidir quién deba ser admitido en el juego. Esta decisión no parece que sea difícil, porque existe una opinión compartida que no existe democracia si no existe la plena participación de todos los hombres en la vida de la sociedad civil: pero he aquí que emerge un valor sustancial, sobre el que fundar cualquier juego social: es necesario presuponer que a todos los hombres compete el derecho fundamental a formar parte de manera activa y personal en la comunidad política y que ninguna deliberación, incluso tomada por mayoría, respetando rigurosamente la vía procedimental, puede quitar este derecho. La EV., en definitiva, clama una democracia sustancial y no meramente formal, o, dicho de otro modo, una exhortación por la defensa y la promoción de los derechos humanos como fundamento y, a un tiempo, la razón misma de la existencia de la comunidad política. 
El tercer desafío emerge de las páginas de la EV. que conciernen el tema de la inocencia. En conformidad con el n. 72, el ponente manifiesta que la insistencia sobre la inocencia es de gran interés kerigmático: la inocencia hace perceptible cómo el anuncio de la Encíclica no tenga, en primer lugar, la vida como mero hecho biológico: el hecho biológico, que es la vida, encierra en realidad un valor absoluto, que el Estado debe respetar, porque, a partir de este respeto, a su vez, el Estado adquiere la razón de ser.

Todo sistema jurídico puede afectarse y construirse a partir de dos paradigmas. El primero es aquel por el que el derecho es estructura al servicio de la voluntad del poder: es la prospectiva que ama cualificarse como realista o como positivista, cuyo objetivo único es el de construir un sistema jurídico como un anónimo sistema de fuerzas contrapuestas, gobernado no en relación a la justicia, sino en relación a la efectividad del poder, cuya medida como poder jurídico, la encuentra únicamente en la dimensión sancionadora. En este horizonte el tema de la inocencia no tiene espacio; la inocencia no es un valor que el derecho esté llamado a tutelarlo, sino que se reduce a una calificación subjetiva, intrínsecamente vacía e insignificante, reconducible a una benigna concesión del sistema jurídico, una concesión que hace referencia a la misma soberana e impersonal arbitrariedad, con la que el sistema puede imputar una culpa a un determinado sujeto: entre culpa e inocencia no se da, en definitiva ningún paso axiológico; son dos dimensiones diversas por sus efectos sociales.

El segundo paradigma lee el derecho como estructura que tiene la razón de su existencia en la defensa de la inocencia. Como garantía de la coexistencia, como administración de la justicia, el sistema jurídico posee en la inocencia el propio presupuesto, la propia estrella polar: los hombres se relacionan recíprocamente, porque se fían los unos a los otros y confían en la recíproca inocencia. La inocencia hace referencia a la verdad de las relaciones interpersonales. Y por esto no existe nada más injusto que la violencia contra el más débil y nada más desagradable del engaño que mira a hacer aparecer culpable el inocente.

El ponente, haciendo alusión a las reacciones habidas respecto a la EV., muchas de ellas por una errada comprensión epistemológica de su mensaje y otras, aun comprendiéndola, teniendo la intención de rechazarla, dice que el rechazo equivale a negar que el horizonte que anuncia tenga fundamento. A mantener que el hombre no posea dignidad alguna intrínseca, que no sólo la fraternidad, sino la misma igualdad sea un mito $\mathrm{y}$, coherentemente, que la misma democracia sea un mito. Y que el derecho no está llamado a defender siempre y en cualquier parte a los inocentes, sino sólo aquellos que el sistema jurídico retenga — a su absoluta y arbitraria discreción- que deben ser defendidos. 
Termina su ponencia dirigiéndose a los juristas en concreto. Los juristas no pueden construir autopoéticamente su saber, porque la verdad del derecho está fuera del mismo derecho. En cuanto ciencia, también la jurisprudencia está llamada a respetar las exigencias de la reflexión coherente y sistemática de la dianoesi; en cuanto letrados también los juristas conocen bien la fatiga de la perinoesi, la dura fatiga que implica el deber de girar en torno al objeto. Pero no puede ser menos en los juristas el conocimiento que, junto a la dianoesi y a la perinoesi se pone la dimensión ananoética, aquella del anuncio kerigmático (defiende la vida). El kerigma lo que pretende es fundar una realidad nueva: ser todos hijos de Dios y consiguientemente, todos hermanos (n. 77).

18. Abierto el debate, se resalta que los poderes públicos no tienen voluntad de asumir el anuncio kerigmático. Según el ponente, el pensamiento teológico es la base iluminante del derecho, en cuanto muestra que el derecho en sí mismo no encuentra su justificación. El derecho necesita un alma. Por otra parte, el ponente, contestando a una congresista, que se autoconfiesa hebrea, que manifiesta la contradicción que encierra el Estado de Israel al proclamarse como Estado democrático y judío, dice que el precepto de amar debe fundarse en un concepto epistemológico: no sólo se debe amar porque se es hebrea, sino porque se es persona. Otro de los congresistas pregunta si el olvido de la teología hace referencia a la teología del pasado o a la teología de hoy, y acto seguido dice que no a la teología, sino a la transformación cultural se debe esta situación. La respuesta del ponente es que no hay lugar a este discurso. Al congresista que plantea si estima el ponente una lectura teológica-óntica de la EV., le contesta que se está refiriendo a una teología moral.

19. Seguidamente se lee dos comunicaciones. Una, con el título «Diritto naturale-Diritto positivo» por el prof. de Filosofía del Derecho en la Universidad de Oxford, John Finnis y la siguiente «L'Insegnamento della Filosofia del Diritto (Diritto naturale) nella Facoltà Di Giurisprudenza» por el prof. de Filosofía del Derecho en la Universidad de Lecceltalia, Antonio Tarantino.

El prof. Finnis comienza la intervención, recordando algunas verdades elementales sobre la ley natural.

Cuando deliberamos tan inteligentemente, como podemos para hacer una elección que sea la más racional posible, nos damos cuenta de ciertas razones fundamentales para la acción. Estas razones primarias y básicas de las que se derivan las demás razones para la acción, nos orientan hacia unos bienes igualmente primarios y básicos que queremos alcanzar con nuestra acción, bienes humanos fundamentales. Sto. Tomás llama 
primeros principios de la ley natural a los enunciados, que nos hacen considerar los bienes básicos como cosas buenas, que hay que lograr y su negación como cosas malas, que hay que evitar.

La expresión «ley natural» está compuesta por dos palabras: «ley»y «natural».

En esa expresión la palabra «ley» está tomada en un sentido análogo al que se utiliza al hablar de leyes de los Estados, o de los clubes o de los juegos. Pero, en esa analogía, las diferencias son, por lo menos, tan importantes como las semejanzas. La orientatividad de los principios de la ley natural, su normatividad, sus exigencias en nuestro razonamiento práctico y en nuestras elecciones no son sino orientatividad, normatividad y exigencias racionales de la verdad, que debe ser afirmada, porque la captamos por un acto claro del entendimiento y por una inconfundible intuición («insight»).

Los mencionados principios de la ley natural no solamente son inteligibles y verdaderos. Son, además, «naturales» o «de la naturaleza». Y puede llamarse naturales por dos razones:

a) Los principios de la ley natural son principios racionales y, precisamente, actuar racionalmente es el rasgo más específico de la naturaleza humana.

b) Los bienes hacia los que nos orientan los primeros principios de la ley natural son aquellos que más profundamente intervienen en el desarrollo integral de la naturaleza humana.

Dentro de la ley natural los autores distinguen los preceptos morales de la ley natural y los preceptos específicos de la justicia. Entre estos últimos, unos tienden a proteger bienes intrínsecos a la persona humana, como la vida y otros bienes que no lo son, v.g. la propiedad. En la reflexión ha sido posible identificar algunos derechos humanos o naturales como fundamentales: «derechos fundamentales del hombre».

Tarea primordial del Gobierno y de las leyes de un Estado es hacer lo posible para salvaguardar eficazmente los derechos de cada ciudadano y su pacífica armonización; la adecuada promoción de la honesta paz pública, que consiste en la ordenada convivencia en la verdadera justicia; la debida custodia de la moralidad pública.

Toda la legislación de un Estado es ley positiva. Su articulación con la ley natural puede darse de varias maneras: a) la ley positiva unas veces positiviza preceptos de la ley natural, que no admiten excepción, v.g. no se puede quitar nunca la vida a un inocente. b) Otras veces, la ley positiva impone preceptos, que se derivan de la ley natural por deducción. c) Otras veces, la ley natural no concreta nada sobre alguna cuestión concreta y la ley positiva determina y especifica el contenido genérico de la ley natural. En este último supuesto la ley positiva tiene un amplio mar- 
gen para elegir una opción u otra, pero, en todo caso, los principios de la ley natural constituyen una barrera que no se puede franquear.

Es sabido que muchos filósofos del Derecho, como Norberto Bobbio, defienden la posibilidad de una ley positiva válida, aunque sea injusta. Según esta teoría, una ley promulgada, después de haberse cumplido todos los requisitos formales para su producción, es una ley válida. Eso no impide que sea considerada injusta por algunos ciudadanos. En ese caso, éstos deberán trabajar para lograr que se cambie el contenido de esa ley mediante otra ley que cumpla, también, con los requisitos exigidos en la Constitución para su elaboración.

La doctrina tradicional afirma, como dice Sto. Tomás, que una ley injusta no es ley, sino abuso de ley, y, «aunque esté dotada del hecho social de la validez legal, no es verdaderamente una ley». Por lo tanto, en conciencia no hay obligación de obedecerla. Es la misma doctrina que se expone en la EV. (n. 73).

El relator, después de unas consideraciones sobre el problema que plantean este tipo de leyes a algunos profesionales, como los médicos, enfermeras, jueces, formula su opinión sobre la función de la ley positiva: «La ley positiva es, esencialmente, una empresa humana de la razón práctica que se esfuerza por promocionar bienes humanos y verdades prácticas».

Según los autores, la corrupción se introduce en las leyes de dos maneras:

1) La injusticia de una parte de la legislación se va extendiendo a otras partes de la misma, aduciéndose para ello razones de analogía que justifican las nuevas injusticias. Por ejemplo, el aborto por causas de salud física se amplía a causas de salud psíquica que, a su vez, incluyen como motivos poderosos deseos o aversión. Los principios que se aducen para justificar el aborto se extienden para abarcar el aborto eugenésico y el infanticidio. Cabe decir lo mismo con respecto a la eutanasia. La eutanasia voluntaria madurará rápidamente hacia una muerte no voluntaria de muchas personas, de las cuales se dirá —y tal vez se creerá- que, si pudieran hacer uso de su razón, desearían que se les quitase la vida.

2) La promulgación de la ley es siempre, quiérase o no, un acto de enseñanza, que pretende dar cuenta de aquello a que la ley natural y la naturaleza humana nos invita, si no es que nos exige. Una ley positiva injusta, sobre todo, si es intrínsecamente injusta, es un falso maestro. La intrínseca injusticia de sus invitaciones inmediatas a cooperar en una conducta injusta (wrongful conduct) está compuesta por las falsedades que proponen o insinúan: una academia de ulteriores y más amplias violaciones del bien del hombre para todos aquellos que no se desligan de los tentáculos del error y, conscientemente, encuentran su camino de espaldas a los verdaderos principios. 
El prof. Tarantino dice que la importancia de la Filosofía del derecho deriva del hecho, que existente la estricta conexión de la Filosofía del derecho con la ética, existente el pluralismo ético, se puede presentar una pluralidad de Filosofías del derecho (filosofía aristótelico-tomista, filosofía analítica, filosofía del neopositivismo lógico-jurídico), las cuales, obviamente, se proponen como portadores de los diversos tipos de valoración crítica en las confrontaciones del derecho positivo.

El problema estriba en el punto de partida; presupuesto que, a su vez, corresponde a un tipo de antropología filosófica. Una cosa, de hecho, es poner como fundamento el conocimiento del hombre en la totalidad de sus caracteres esenciales, otra en algunos de sus caracteres esenciales y otra en lo que no pertenece a su estructura ontológica, es decir, a sus caracteres no esenciales.

El verdadero problema, sin embargo, se presenta, en el momento en el que, aceptando como fundamento el conocimiento del hombre en la totalidad de sus caracteres esenciales, se intenta establecer a cuál de estos caracteres esenciales reconocemos una situación de privilegio.

Sostener como punto de partida el principio «veritas facit legem», indicar la «veritas» en la estructura ontológica de la persona, como punto ineludible de la teoría de las fuentes del derecho, significa indicar, con claridad, el fundamento de la justicia no en los principios de una justicia racionalmente convenidos, sino en los puntos firmes de la naturaleza. En una palabra, para que a la Filosofía del derecho le sea reconocida la función de valoración crítica, es necesario que la misma tenga algo que criticar, el derecho positivo; es necesario que sea reconocida la dicotomía derecho natural-derecho positivo, que está presente ya desde Sófocres.

Deseando sintetizar, en grandes rasgos, la situación de las doctrinas filosófico-jurídicas de nuestros días, el relator las concreta en dos líneas:

La línea «empírica» que asigna al derecho una función de control social, y es el baluarte del pensamiento historicista, positivista y neopositivista, que han vaciado la función de valoración crítica del derecho natural respecto al derecho positivo. Se trata de un vacío determinado por la sustitución de la trascendencia con la inmanencia, en el caso del historicismo; por la consideración de la inutilidad de reconocer a la filosofía la función valorativa del hecho empírico, en el caso del positivismo; por la reducción de la Filosofía del Derecho a rigurosos procedimientos lógicos, teniendo como punto de partida los resultados de las continuas encuestas sociológicas, en el caso del neopositivismo lógico-jurídico.

La línea «metafísica». El ponente distingue dos posturas dentro de esta línea: a) Quienes justifican la validez de sus valores en la estructura de la existencia (fundamento ontológico). En esta óptica, partiendo de datos ciertos que la sociedad ofrece en un determinado momento históri- 
co, el derecho es visto como creación y construcción del intérprete. Es una línea ésta que, en todas sus articulaciones, sólo «lato sensu» cabe remitirla a la tradición filosófica - jurídica clásica-, en cuanto no siempre consigue dar una valoración crítica del derecho positivo basada en los principios absolutos de justicia; b) La tradición filosófica-jurídica clásica, en cuyo ámbito el derecho natural y el derecho positivo no son completamente autónomos. El ponente esta situación la representa así: a) el derecho natural para valorar críticamente el derecho positivo debe conocerlo, y lo conoce porque su relación es vista desde la perspectiva que va del orden ontológico al orden ideal, como representación del orden ontológico, al orden ético, al orden político y jurídico; b) científicamente es correcto pasar del plano ontológico de una realidad, en nuestro caso de la persona humana, al plano de la definición gnoseológica de la misma, por lo que científicamente está justificado pasar de la descripción a la prescripción. En este ámbito se ve «el eterno retorno del derecho de la naturaleza». Por ello, decir Filosofía del derecho significa decir Filosofía de la ley ínsita en lo creado, en la naturaleza, cuya ley, tutelando el orden vital humano, tutela «los constitutivos» de la persona.

Es preciso precisar - continua el relator- a qué tipo de derecho natural nos referimos.

$\mathrm{Si}$, en los años 40, Rommen escribía que «ningún positivista afirmará ahora que este "ser una persona" y los derechos que dimanan, en primer lugar, el derecho de ser reconocido también jurídicamente como persona, "nacen de la voluntad del Estado"», hoy, lo que aún es peor, la facultad de reconocer los derechos fundamentales se fundamenta sobre la base de la naturaleza biológico-evolutiva del hombre. Así, se cualifica como persona sólo a los individuos humanos «autoconscientes, racionales y en posesión de un sentido moral mínimo», es decir, sólo los individuos autónomos. En consecuencia, no son personas, los embriones, niños, retardados mentales, etc.

Se lamenta de no ver la diferencia entre titularidad de los «constitutivos» (derechos) del individuo humano y su ejercicio, condicionado a su evolución ontogenética. Quienes no distinguen, critican a Kant por no haber diferenciado «la libertad como valor y la libertad como vínculo colateral» y encerrarse sobre la libertad como valor.

Lo que daña a estos pensadores - dice- es haber privilegiado excesivamente la dimensión relacional, el no haberse interesado por los «constitutivos» de la persona en su momento fundante. Tales pensadores debieran haber considerado en pro de su tesis, que la esencia del hombre no se agota ni en el sólo «vínculo colateral», ni en la sola individualidad de la persona. Debieran haber tenido presente que la «sociabilidad» es un elemento igualmente constitutivo de la naturaleza del hombre como lo es su racionalidad. 
La ética que proponen estos pensadores es una ética en la que se deja ver una libertad privada de leyes ontológicas, una racionalidad abstracta, individual, que puede decidir, precisamente abstractamente e individualmente, el tipo de programas de vida que cada ser humano puede formular.

Debieran prestar mayor atención a la sociabilidad de la persona y, conjuntamente a su fundamento: si así lo hicieran, se darían cuenta que: 1) de la estructura ontológica del hombre, de la sociabilidad del hombre, como su momento constitutivo, desciende la necesidad ontológica de la familia; 2) la familia es anterior al Estado; 3) la natural integración de los derechos y deberes se fundamenta en la esencia del hombre, en su sociabilidad y en su racionalidad.

En el contexto del derecho natural clásico la racionalidad y la sociabilidad implican un tipo de derecho positivo respetuoso de las leyes ontológicas, por el que es difícil la existencia de fugas peligrosas para la vida individual y social. No puede afirmarse lo mismo si el proceso social del perfeccionamiento del hombre es visto desde el derecho natural moderno. Si se parte del individuo sin vínculos recíprocos, con sus derechos al margen de su relación con los derechos de los otros o el punto de partida es sólo la libertad como «vínculo colateral», se justifica un derecho positivo, que prevé y tutela los derechos fundamentales, en la medida en que son aceptados y propuestos por la vía acordada o convencional, de la que brota este o aquel programa político tutelar de derechos y deriva, por añadidura, la justificación de la violación de este o aquel derecho fundamental.

Ve que lo que impulsa actualmente a violar el derecho a la vida es la difusión de una ética «lato sensu» empirista, cuya causa remota es la concepción individualista y abstracta de la persona humana. Lo que va desapareciendo en estas últimas décadas es la dimensión sapiencial de la vida individual y social, y, ello es debido al desinterés de enfrentarnos con la verdad de las cosas como fuente próxima de las leyes, y, por ende, con los principios de justicia y su fundamento. Justamente a este respecto en la EV. se recuerda que, cuando la libertad «no reconoce ni respeta su vínculo constitutivo con la verdad... la persona acaba por asumir como única e indiscutible referencia para sus propias decisiones no ya la verdad sobre el bien o el mal, sino sólo su opinión subjetiva y mudable o, incluso, su interés egoísta y su capricho» (n. 19).

El relator, a tenor de estas consideraciones, sostiene que la enseñanza de la Filosofía del derecho como derecho natural clásico es indispensable, si no se quiere renunciar a una valoración crítica que afronte al derecho positivo no respetuoso de la inviolabilidad de la vida y de la incoercibilidad de la libertad. 
20. La última relación del simposio cae a cargo del prof. de Filosofía del Derecho en la Facultad de Derecho en la universidad de MendozaArgentina, Carlos Ignacio Massini Correas: «Il diritto alla Vita nella sistematica dei diritti umani».

$\mathrm{Su}$ extensa ponencia intentaremos resumirla, evitando la reiteración de lo plasmado en las que le preceden.

En su introducción desea hacer algunas precisiones, la primera de ellas se refiere a la expresión «derecho a la vida», que estrictamente designa «derecho a la inviolabilidad de la vida». La segunda hace referencia a la expresión «vida», que designa precisa y exclusivamente a la vida humana, precisión oportuna, al existir una corriente de pensamiento que sostiene la existencia de derechos estrictos de los que son titulares entes no humanos.

Hechas estas aclaraciones entra en el desarrollo del tema. La noción de derechos humanos hace referencia que el fundamento de los mismos radica en la dignidad personal de todo ente humano y su contenido material viene dado por los bienes humanos básicos, que orientan la conducta de los hombres para escoger y obrar en ciertas y determinadas direcciones. Entre esos bienes humanos que especifican los derechos humanos está el derecho a la inviolabilidad de la vida. Este derecho ha de durar durante todo el tiempo de persistencia del bien, es decir, desde la concepción hasta su muerte. Desde el momento que exista un individuo que pertenece a la especie humana, debe existir también el derecho a que no se lo prive de nada. El ponente no acepta la dicotomía persona-individuo, por lo que se opone a esa corriente del pensamiento actual, como la de Engelhart entre otros, de que sólo son titulares de este derecho las «personas», cuya noción no es coextensiva con la de entes humanos, ya que existirían entes humanos que no son personas, v.g., los fetos, las criaturas, los retrasados mentales profundos y los que se encuentran en coma profundo. Estas entidades son (sólo) miembros de la especie humana. Las consecuencias de este pensamiento serían el establecimiento del principio de que la muerte de una persona puede ser moralmente lícita en ciertas circunstancias o dentro de ciertos límites, y aceptado este principio, todos estamos en peligro de ser asesinados.

Haciéndose eco de toda una serie de pensadores de origen anglosajón, sobre todo, pertenecientes a la escuela utilitarista, que sostienen que los derechos humanos son sólo derechos «prima facie», es decir, que pueden ser derogados, sobrepasados o suspendidos en el caso de que su respeto acarree consecuencias dañosas para el deudor o para la sociedad en general, manifiesta que este «derecho prima facie» no puede llamarse derecho, pues nadie puede «tomar en serio» un derecho que está sujeto a la condición suspensiva de que el deudor pueda no cumplirlo por razones 
de utilidad. Como consecuencia no existiría propiamente «derecho» alguno, pues todo derecho supone indefectiblemente la necesidad deóntica del cumplimiento de su objeto.

Del mismo modo, el derecho a la inviolabilidad de la vida se tiene o no se tiene: si el sujeto es un ser humano-persona, y no se dan ninguna de las causales eximentes de responsabilidad, v.g., la legítima defensa, ese sujeto tiene el título completo que funda la existencia de su derecho a la inviolabilidad de la vida.

Respecto a la ubicación de este derecho en el contexto sistemático de los derechos humanos, afirma que este derecho se encuentra en un rango superior al del resto de los derechos. A nivel especulativo, mientras los demás derechos se refieren a perfecciones humanas, que revisten un carácter existencialmente no autónomos, el valor básico de la vida hace referencia directa al modo de existir propio de los entes humanos, que es existencialmente autónomo o sustancial. A nivel práctico, la vida tiene un carácter especial en cuanto bien básico. Atentar a la vida implica un atentado indirecto al resto de los bienes humanos básicos, ya que su ausencia impide la posibilidad misma de su concreción.

Haciéndose eco del desprecio de la vida, cuyo fenómeno abarca una gran cantidad de dimensiones de la vida humana, considera que la razón fundamental radica en la ruptura, cada vez más radical, de cualquier referencia a un Ser absoluto y trascendente, fuente radical, por vía de participación, de la dignidad que compete a todo ser humano. La dignidad, en cambio que un hombre se confiere a sí mismo o le otorgan otros, desvanece apenas el mismo sujeto o los otros cambian de opinión respecto a esta dignidad, de forma que los derechos se transforman en «edictos de tolerancia esencialmente revocables» ${ }^{7}$.

21. Tras esta relación, sin debate posterior, se entrega a los congresistas un texto conclusivo en lengua italiana, que posteriormente es leído para su aprobación. Dada la premura de tiempo, según la presidencia, se omite hacer públicas las observaciones que se consideren pertinentes, instando a los congresistas que las depositen, llegado el caso, en la secretaría del simposio.

El texto es publicado en el L'Osservatore Romano ${ }^{8}$. En aras de la brevedad, intentaremos resumirlo.

A. Conclusioni dottrinali. Se afirma: 1. Que el único modo de fundar los derechos de la persona humana se encuentra en el ligamen entre libertad y verdad. 2. La EV. aprecia la democracia, el Estado de derecho

7 OR., 29 de mayo 1996, 6.

8 OR., 29 de mayo 1996, 6. 
y la cultura de los derechos humanos, reconduciéndolos a su auténtico fundamento y a su auténtica finalidad, que consisten, primariamente, en la defensa de la vida. 3. El derecho a la vida está en la base de todos aquellos valores humanos y morales esenciales y nativos que brotan de la verdad misma del ser humano y expresan y tutelan la dignidad de la persona. (...) Se augura que los ordenamientos jurídicos positivos se abran al reconocimiento de la plena dignidad del embrión humano y de sus derechos inalienables y procedan a elaborar las normas que garanticen la adecuada tutela a la vida humana prenatal, prohibiendo todas aquellas prácticas — incluso las de fecundación asistida - que amenazan la vida, la salud, el mismo patrimonio genético de los embriones. 4. Los participantes del simposio comparten no sólo en la firme condena de la EV. respecto a cualquier ley que atente al bien de la vida, sino también en la denuncia de tales leyes como injustas y privadas de auténtica validez jurídica. Auguran que tales ordenamientos jurídicos, en los que emanan las leyes contra el derecho a la vida, prevean expresamente la objeción de conciencia como un derecho de los médicos y, en general, de todos los operadores y responsables de las instituciones sanitarias. Auguran, también, que la objeción de conciencia no implique discriminación alguna en el orden académico y profesional.

B. Conclusioni per la vita accademica. 5. Se declara el convencimiento de la enseñanza del derecho natural y se deplora su vacío en muchas facultades jurídicas, pues con la expresión «derecho natural» se intenta el conocimiento que el derecho positivo no es suficiente por sí mismo, porque la justicia de sus normas no depende de la mera voluntad del legislador, sino de su arraigo en la verdad misma del hombre y de la coexistencia social. 6. Los participantes advierten el error de quienes consideran que el positivismo pueda reternerse científicamente y políticamente correcto y, en plena coherencia con la tradición secular, repiten que la reducción del derecho al mero derecho positivo y la negación del nexo constitutivo que une verdad, libertad y derecho es fatal para la existencia del derecho mismo. 7. Apelan, por lo tanto, a todos los docentes del derecho para que ofrezcan a los futuros juristas una sólida base de formación antropológica y ética, abierta al reconocimiento de los valores de la persona humana. Esta formación deberá contribuir y activar una nueva cultura de la vida. 8. Los participantes, conscientes de la necesidad de esta formación, requieren nuevos centros de estudio, incluso, interdisciplinares, congresos y seminarios y la publicación de libros y revistas.

C. Conclusioni socio-politiche. 9. Los participantes del simposio repiten las palabras del Santo Padre «respeta, ama y sirve a la vida, a toda vida humana» (EV. n. 5) e insisten por dirigir estas palabras, especial- 
mente, a los legisladores, a los jueces, a cualquier operador jurídico que tenga la autoridad de decidir sobre cuestiones de la vida humana a nivel local, nacional e internacional. 10. Los participantes de modo particular desean estimular a todos los hombres de buena voluntad, y cristianos en primer lugar, a defender la vida humana, aunque sea con graves esfuerzos y sacrificios. Saben bien la dificultad que existe, en casos concretos, para una mujer, incluso al límite heroico, acoger la vida que nace y para una familia asistir a un enfermo crónico o terminal y, en general, para todos asumir actitudes explícitas en defensa de la vida; pero desean recordar que en estas actitudes, incluso las del heroísmo, no hay nada de inhumano. 11. Piden a todos los juristas el compromiso sin pausa para que el derecho venga restaurado, para que las leyes injustas vengan reconocidas como tales y, en consecuencia, abrogadas. Auguran, además, que el art. 3 de la Declaración Universal de los Derechos del Hombre de la ONU venga plenamente acogido en todos los ordenamientos jurídicos positivos de los Estados del mundo. 12. Los participantes son conscientes que muchas actitudes hostiles al derecho a la vida provienen de órganos gubernativos y no gubernativos, que se hacen eco de una parte de la opinión pública. Pasan por alto, por desgracia, las convicciones morales de un número no menos consistente de personas o pueblos que, independientemente de la cultura y religión, son sensibles a la sacramentalidad de la vida y a su defensa. Auguran, por lo tanto, que los representantes de las naciones estén más atentos al sentido moral de tantos que consideran la vida como un valor humano fundamental que hay que respetar y defender. 13. Los participanes exhortan a los políticos a no adaptarse a criterios que contradicen los valores humanos y jurídicos fundamentales y especialmente a combatir las fuertes presiones a favor de una siempre mejor articulada legislación abortista y eutanásica (...) —en particular, a aquellos que con bravura («fiereza») debieran manifestar su identidad de católicos- a no tener miedo de declarar públicamente (...) su intención de ponerse al servicio de la vida y de asumir la verdad del hombre como norma y fundamento de su praxis en la materia, recordando la posibilidad que ofrece la EV. por promover iniciativas legales que miren a limitar el daño de las leyes abortistas y, en general, contrarias a la vida humana (n. 73c). 14. Los participantes conscientes de los egoísmos individuales y colectivos (...) auguran que todos los hombres tomen conciencia, incluso para desacreditar la falsa idea que las leyes contra la vida tengan sabor progresista y humanitaria. 15. Los participantes convencidos del rol de la mujer en la construcción de una nueva civilización del amor y de la vida, auguran un compromiso por parte de todos en pro de una transformación cultural a nivel universal, que asocie la defensa de la dignidad y de la libertad de la mujer con la de la vida humana. 


\section{Reflexiones}

El objetivo del simposio era, en palabras del Emmo. Cardenal Trujillo, reflexionar acerca de la incidencia que los principios morales sancionados en la Encíclica han tenido en nuestro mundo legislativo, jurisprudencial y académico.

El articulista Mario Ponzi manifiesta que desde el Simposio, en definitiva, han llegado indicaciones precisas para recuperar el pleno sentido de aquella cultura de la vida que algunos parecen renegar en nombre de una «democracia voluntariamente separada de la ética, que define la verdad sobre el hombre y la defensa de sus derechos inviolables "desde el punto de vista católico"» ${ }^{9}$.

Personalmente matizaría la expresión «democracia voluntariamente separada de la ética», a no ser que se afirme que la única ética que quepa denominarse como tal, sea la marcada por la filosofía aristotélica-tomista.

No nos agrada tampoco la expresión «desde el punto de vista católico», porque en ese caso reduciríamos la irradiación doctrinal de la Encíclica al mundo del catolicismo, cuando en realidad la Encíclica es «una acuciante llamada a todos y a cada uno, en nombre de Dios: ;respeta, defiende, ama y sirve a la vida, a toda vida humana! ${ }^{10}$.

Partiendo de la unidad doctrinal de las Encíclicas «Veritatis Splendor» y «Evangelium Vitae», el Simposio ha girado en torno al eterno problema del «Derecho natural». Y este problema en la conyuntura histórica que vivimos ha sido analizado tanto a nivel de información como formación desde los diversos ángulos del saber filosófico, ético, político, teológico y jurídico.

A nuestro entender, un tema de tanta trascendencia, como es el derecho a la inviolabilidad de la vida, demandaba oír voces de otras confesiones, solamente se nos informa del mundo musulmán, y, de expertos y peritos de la ciencia y del derecho que no compaginan con nuestros postulados. Hubiera sido más enriquecedor para todos los allí presentes.

Yendo al objetivo del Simposio, el querido y paciente lector de esta memoria caerá en cuenta que la incidencia de la Encíclica «Evangelium Vitae» ha sido más bien parca, por no decir nula, como se desprende de la comunicación de Mons. Minnerath. Hoy, como afirma el prof. Tarantino, se parte del individuo sin vínculos recíprocos, con sus derechos al margen de su relación con los derechos de los otros, o de una libertad

\footnotetext{
9 MARIo PonZI, «La difesa della vita umana no può essere considerata un semplice "punto de vista"», en L'Osservatore Romano, 29 de mayo 1996, 6.

${ }^{10}$ EV., n. 5,
} 
como «vínculo colateral», justificando un derecho positivo, que prevé y tutela los derechos fundamentales, en la medida en que son aceptados y propuestos por la vida acordada o convencional. Por ello, podemos decir que del primado del derecho sobre la política hemos pasado al primado de la política sobre el derecho (v. D'Alla Torre). En consecuencia, esta filosofía neopositivista lógico-jurídica produce en nuestro hábitat la «sociedad de excluidos» en los más diversos ámbitos (v. Serna).

Este primado de la política sobre el derecho está plagado de ambigüedades, sea a escala internacional como nacional, a tenor de lo que se desprende de la escucha y lectura de las ponencias y comunicaciones.

A nivel conceptual, no sabemos qué es ser "persona», qué es ser humano, qué es matrimonio, qué es familia, qué es maternidad, etc.; a nivel científico, nos invade las dudas del momento del nacer y del morir de la persona, ¿hasta dónde puede extenderse el campo de la ingeniería genética?; a nivel social, ¿es posible admitir la dicotomía individuo-persona, y en razón de esta dicotomía afirmemos que los así llamados individuos «no autónomos» (los fetos, los retrasados mentales, los terminales), no son personas y, en consecuencia, no tienen derecho a la inviolabilidad de la vida?; a nivel jurídico, ambigüedades en relación con la tutela de la vida, tanto en la legislación como en su interpretación y aplicación jurisdiccional.

No obstante, el panorama que se vislumbra, que para el prof. MayerMaly es sofocante y pésimo, deja algunos retazos de luz, pues la misma comunidad internacional desea renegociar una Declaración Universal de los Derechos del Hombre (v. Minnerath) y se siente converger acerca de la necesidad de establecer legítimamente un «estatuto del embrión» que establezca los confines y límites (v. D'Alla Torre). Leemos en uno de nuestros medios de comunicación que «Cuando la investigación científica no tiene limitaciones tecnológicas, es imprescindible que la sociedad regule sus avances», refiriéndose al diseño de un «vientre artificial», elaborado por dos equipos de investigadores del Reino Unido y Japón, en el que se podrían concebir y desarrollar fetos hasta el momento de su nacimiento. Y, siguiendo la lectura, se dice: «...para aprovechar su beneficio social sin desnaturalizar su esencia es necesario desarrollar una legislación que asegure que se emplean dentro de un marco ética y humanamente aceptable ${ }^{11}$. Por no hablar del rechazo de la mujer joven americana al feminismo oficial hacia el matrimonio y la maternidad, por su actitud antagónica respecto a los hombres, por su intolerancia a que se pueda disentir de su toma de posición en temas como el aborto o la homosexualidad (v. Glendon).

11 El Mundo, 18 de agosto, 1996, 4. 
Creemos que el respeto de la dignidad del ser humano sólo es posible si se respeta el orden de la creación, que, para los creyentes en Dios, se eleva, no se destruye, y se ilumina en el orden de la redención (v. Cafarra, D’Agostino, Serna). Desde estas coordenadas el hombre creado a «imagen de Dios» ${ }^{12}$ puede asumir responsablemente unas decisiones, «de modo que sepa buscar espontáneamente a su Creador» ${ }^{13}$. Posee un modo de sentir y de actuar que le pone en contacto a nivel de conciencia con los valores y con la verdad (v. Caffarra) ${ }^{14}$. Entre esos valores, emerge el valor de la vida, superior al resto de todos los valores, pues su inviolabilidad está indisolublemente unida a la dignidad de la persona.

La sustancia de este anuncio nos invita a la capacidad de querer y de sustraernos a la omnipresente tentación de ceder a la ciega (y por tanto violenta) neutralidad (v. D'Agostino). En un artículo referente a la eutanasia, citando al Card. Martini, decíamos: «Una cultura de la legalidad debe enraizarse en un profundo "ethos" personal y social. Las leyes deben respetarse no sólo por su valor formal o por las sanciones que conllevan su inobservancia (si así sucediera, entraríamos en el puro legalismo), sino también y, sobre todo, por su valor y significado intrínseco, por su capacidad de representar los ideales y fines de la colectividad, que no pueden ser otros que el desarrollo integral de la persona (legitimidad material) $)^{15}$ ».

Esta creencia no debe obnubilar, por otra parte, la realidad de la historia que nos toca vivir, asentada en el pluralismo como valor absoluto. Esta realidad llama a nuestras puertas y por nuestra parte debemos estar atentos a su llamada. ¿Cómo? Proponiendo y convenciendo, que en una sociedad, en la que nadie posee la verdad total, termina imponiéndose la voluntad del más fuerte. Por ello, evidenciamos que la ley, si es puramente humana, no puede ser principio fundante del orden ético, ya que ella misma está postulando unos principios metajurídicos de legitimación.

Esta demostración excluye caminos imperativos y exige caminos dialogantes (v. Glendon, Ollero), pues lo que se pretende es fundar una realidad nueva: ser todos hijos de Dios y, consiguientemente, todos hermanos (v. D' Agostino).

Confesamos sinceramente que esta vía dialogante no rezuma el texto conclusivo en lo que afecta al mundo académico como al mundo sociopolítico.

12 GS., n. 12

13 GS., n. 17

14 DH., n. 2

15 P.M. GARÍN, «El Derecho a vivir el morir», Estudios Deusto, vol. 41/2, julio-diciembre 1993, 105. 
Vienen a mi memoria las palabras del Card. Cardijn en el aula conciliar, cuando, se debatía la declaración sobre la libertad religiosa: «La confianza entre los hombres es una condición necesaria para la construcción de un mundo más humano (...). Si existen peligros en el régimen de libertad, ésos deben eliminarse mediante una acción positiva (...). La Iglesia no puede actuar como actuaba en el Medioevo o bajo los regímenes colonialistas (...) es necesario tener presente los valores educativos y pedagógicos de la libertad en la formación de los jóvenes, a los que no se debe impartir una educación basada bajo la coacción, sino una educación abierta basada en la libertad: ésta produce mayores responsabilidades ante Dios, capaces de obedecer siempre más a Dios que a los hombres» ${ }^{16}$.

En sintonía con lo que precede, no vemos en las «conclusiones para la vida académica» que la formación antropológica y ética se ofrezca en un régimen de libertad. Tienen más bien un acento dogmático, que, a nuestro entender, no responde a la misión docente. Esta sensación brota, también, de la lectura de las «conclusiones socio-políticas» (v. nn. 12-13). Es cierto que la EV. dice que frente a la ley moral objetiva no cabe «mayorías de opinión» ${ }^{17}$, pero creemos que estas «mayorías» reflejan un modo de sentir, que, aunque para nosotros puedan conducir al error, no por eso pierden su valor ${ }^{18}$.

Opinamos que en esta coyuntura del quehacer político no se trata de enterrar el juego de las mayorías, que en el pensamiento político contemporáneo es el menos malo, sino que, dentro de este juego, el político en temas que afectan directamente al ser o no ser de la sociedad, pues la vida constituye el fundamento de todos los otros bienes de la sociedad, sea libre de expresarse y de votar según conciencia, no sujeto a la dictadura interna del partido. ¿Es una utopía? Al político, que le conste con certeza la imposibilidad de esta utopía, entonces debemos recordarle el discurso «Con felice pensiero» de Pío XII, del 6 de noviembre de 1949, a la Unión de Juristas Católicos Italianos. El Papa se preguntaba si el juez católico puede o no puede sentenciar aplicando una ley o una norma de derecho que el mismo juez juzga como norma injusta. El Papa en su respuesta dice que al juez católico frente a la ley injusta le queda dos posibilidades, el de aplicar la ley en los casos en los que tal aplicación no sea una abdicación moral del juez, o renunciar a su puesto.

Aplicando la doctrina de Pío XII al poder legislativo, creemos que al diputado y, sobre todo, si es católico, cuando se trata de defender la dig-

\footnotetext{
16 II Concilio Vaticano II, en Cività Catolica, vol. V, p. 37.

17 EV., n. 70.

18 EV., nn. 26-27.
} 
nidad de la persona, el respeto de sus derechos inviolables e inalienables, le queda el derecho-deber de impedir toda ley contraria a la vida y, llegado el caso de la existencia de dicha ley y no poder evitar los daños de esa ley y así disminuir los efectos negativos ${ }^{19}$, presentar la objeción de conciencia, que debe ser protegida por la misma ley disciplinar del partido. Si así no fuera, es el mismo partido político que atenta al derecho de conciencia de su afiliado y, por ende, a su libertad, cuyo valor es resaltado como universal en todos los foros internacionales y nacionales.

De manera análoga extendemos este derecho a la objeción de conciencia «a los médicos, a los agentes sanitarios y a los responsables de las instituciones hospitalarias, de las clínicas y casas de salud» ${ }^{20}$.

\section{Audiencia del Papa Juan Pablo II}

Hacemos la observación que los destinatarios del discurso del Papa no solamente fueron los participantes del Simposio, sino también los que intervinieron en el XI «Colloquio internacionale Romanistico Canonistico».

Este congreso tenía como objeto la relación entre Etica y Derecho en el ámbito de la formación de los modernos ordenamientos jurídicos.

Aludimos a los puntos que consideramos que merecen resaltar:

3. El Papa, refiriéndose a la Encíclica «Evangelium Vitae», manifiesta que este documento ha intentado reafirmar la visión de la vida humana, que se desprende plenamente por la revelación cristiana, pero que, en su núcleo esencial, es alcanzable por la razón humana. Tras afirmar que la encíclica ha tenido en cuenta el enriquecimiento que la reflexión racional ha ido madurando al correr de los tiempos, dice: «De hecho, reconocer el valor de la vida del hombre, desde la concepción a su fin natural, es una conquista de la civilización del derecho, que debe ser tutelada como un bien primario de la persona y de la sociedad». Haciéndose eco de que en algunas sociedades contemplamos el regreso de esta civilización, fruto de una incompleta $y$, a veces, distorsionada concepción de la libertad humana, «sucede (...) que al respeto debido al inalienable derecho a la vida de todo ser humano se contrapone una concepción subjetivista de la libertad, desvinculada de la ley moral. Esta concepción, fundada sobre graves errores relativos a la naturaleza misma de la persona y de sus derechos, ha conseguido, valiéndose de las reglas mayoritarias, a introducir no poco frecuente en el ordenamiento jurídico la legitimación de la supresión del derecho a la vida de seres humanos inocentes aún no

\footnotetext{
19 EV., n. 73.

20 EV., n. 74.
} 
nacidos. Es útil, por lo tanto, poner de relieve, en prospectiva sea filosófica que jurídica, la íntima relación entre las Encíclicas "Veritatis Splendor" y "Evangelium Vitae" (...). Afirmar un derecho de la persona a la libertad, prescindiendo de la verdad objetiva sobre la misma persona, hace de hecho imposible la misma construcción de un ordenamiento jurídico intrínsecamente justo, porque es, en verdad, la persona humana —así como ésa ha sido creada - el fundamento y el fin de la vida social, a la que el Derecho debe servir».

4. Tras manifestar que la centralidad de la persona humana en el Derecho se expresa por el aforismo clásico «Hominum causa omne ius constitutum est» y recordar su observación hecha, con ocasión del décimo aniversario del nuevo Código de Derecho Canónico, de que el hombre redimido por Cristo es el centro del ordenamiento canónico, «de igual manera las sociedades civiles están invitadas por el ejemplo de la Iglesia a poner la persona humana al centro de sus ordenamientos, jamás sustrayéndose a los postulados del derecho natural, para no caer en el arbitrio de falsas ideologías. Los postulados del derecho natural son de hecho válidos en cualquier lugar y para cualquier pueblo, hoy y siempre, porque dictados por la "recta ratio" en la que, como explica Santo Tomás, está la esencia del derecho natural». Haciendo mención que este concepto había sido bien comprendido por el pensamiento jurídico clásico, $y$, citando a Cicerón, dice:

5. «Los elementos constitutivos de la verdad objetiva sobre el hombre y sobre su dignidad se enraizan en la "recta ratio", en la ética y en el derecho natural». Frente al humanismo ateo — continúa - es «deber del cristiano y, sobre todo, de los Pastores y de los teólogos, anunciar el Evangelio de la vida, según la enseñanza del Concilio Vaticano II. Este urgente compromiso interpela de modo particular a los juristas cristianos, impulsándoles a hacer emerger en los sectores de su competencia, el carácter intrínsecamente débil de un Derecho cerrado a la dimensión trascendente de la persona. El fundamento más sólido de toda ley que tutela la inviolabilidad, la integridad, la libertad de la persona reside, de hecho, en su ser creado a imagen y semejanza de Dios».

6. Haciendo presente los debates entre biólogos, moralistas y juristas referentes a los derechos humanos, reafirmando la doctrina de la Iglesia que el ser humano viene respetado y tratado como persona desde su concepción, reconociendo que la atribución del concepto persona pertenece al mundo de la filosofía - dice- «no podemos no asumir como punto de partida el estatuto del embrión, que es un individuo humano, teniendo la cualidad y la dignidad propia de la persona. El embrión humano tiene derechos fundamentales, es decir, es titular de constitutivos indispensables para que la actividad connatural a su ser pueda desarrollarse, "secondo un proprio principio vitale". 
La existencia del derecho a la vida, como constitutivo intrínsecamente presente en el estatuto biológico del individuo humano desde la fecundación, constituye, por lo tanto, el punto firme de la naturaleza, incluso, para la definición del estatuto ético y jurídico del "nascituro".

La norma jurídica, en particular, está llamada a definir el estatuto jurídico del embrión como sujeto de derechos, reconociendo un dato de hecho biológicamente inconfundible y en sí evocador de valores que no pueden ser descuidados ni por el orden moral ni por el orden jurídico.

Por la misma razón, considero un deber hacerme intérprete una vez más de estos derechos inviolables del ser humano desde su concepción, para todos los embriones que no raramente están sometidos a técnicas de congelación (crio-conservazione), llegando en muchos casos a ser objeto de mera experimentación o, peor, destinados a una programada destrucción con el aval legislativo.

Igualmente, confirmo como gravemente ilícito para la dignidad del ser humano y de su ser llamado a la vida, el recurso a los métodos de la procreación que la Instrucción "Donum Vitae" los ha definido como inaceptables por la doctrina moral.

La ilicitud de estas intervenciones sobre el inicio de la vida y sobre los embriones humanos ha sido confirmada; pero es necesario que se asuman también a nivel legal los principios sobre los que se funda la misma reflexión moral.

Apelo a la conciencia de los responsables del mundo científico y, de manera particular, a los médicos para que se paralice la producción de embriones humanos, teniendo cuenta que no se vislumbra una vía de salida moralmente lícita para el destino humano de los millones y millones de embriones congelados, los cuales son y permanecen para siempre titulares de los derechos esenciales y, por lo tanto de tutelarlos como personas humanas.

Los mismos gobernantes no pueden escaparse de este compromiso, para que se tutele desde sus orígenes el valor de la democracia, la cual funda sus propias raíces en los derechos inviolables reconocidos a todo individuo humano» ${ }^{21}$.

21 Juan Pablo II, Discurso rivolto ai partecipanti al Simposio su «Evangelium vitae e Diritto» e alla'XI Colloquio internazionale Romanistico Canonistico, en el OR., 25 de mayo, 1996, 5 . 




\section{Estudios de Deusto}

ㅁ․ Universidad de

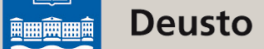

